\title{
DESEMPENHO DE UM MOTOR CICLO OTTO COM INJEÇÃO DIRETA DE GÁS NATURAL
}

\author{
CLEITON RUBENS FORMIGA BARBOSA
}

Tese apresentada à Escola de Engenharia de São Carlos, da Universidade de São Paulo, como parte dos requisitos para obtenção do Título de Doutor em Engenharia Mecânica.

ORIENTADOR: Prof. Dr. Samuel Washington Celere

São Carlos-SP

1997

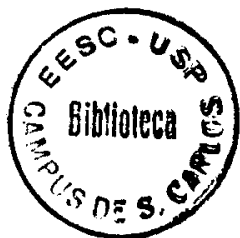


Claber $\frac{T E S E-E E S C}{B 232 \mathrm{dm}}$ Área : Engenharra mecânucia

Tombo I081/97

0747610

Ficha catalográfica preparada pela Seção de Tratamento da Informação do Serviço de Biblioteca - EESC-USP

Barbosa, Cleiton Rubens Formiga

Desempenho de um motor ciclo otto com injeção direta de gás natural / Cleiton Rubens Formiga Barbosa. -- São Carlos, 1997.

Tese (Doutorado). -- Escola de Engenharia

de São Carlos-Universidade de São Paulo, 1997.

Área: Engenharia Mecânica

Orientador: Prof. Dr. Samuel Washington Celere

1. Motor ciclo otto. 2. Injeção direta. 3. Gás natural. I. Título 
A Deus

A minha esposa,

Lenise Paiva e ao meu filho Cleiton Júnior. 


\section{AGRADECIMENTOS}

Ao Prof. Dr. Samuel Washington Celere pela amizade e excelente orientação fornecida durante a elaboração deste trabalho;

Aos professores. Dr. Antônio Moreira dos Santos e Dr. Fernando Milliole, do SEM da EESC-USP, pelas sugestões e apoio fornecidos durante a realização deste trabalho;

Aos amigos professores Francisco de Assis Oliveira Fontes e João Telésforo Nóbrega de Medeiros da UFRN, pelo incentivo e/ou sugestões ao presente trabalho;

Ao amigos Mário Roberto da Silva (colega de pós graduação) e José Roberto Bogni (Técnico do Laboratório de Termodinâmica da EESC-USP) pela brilhante coniribuixão ao desenvolvimento experimental deste trabalho;

Ao Eng. Francisco Torres e Técnicos do Laboratório de Termodinâmica da EESC-USP: Roberto Prata, Roberto Lourênco, Rubens, Sérgio (in memória), pelo apoio técnico dispensado durante a fase experimental do trabalho;

Aos irmãos Cid Robson e Carlos Alberto e ao amigo José Alfredo pela ajuda computacional;

As bibliotecárias da EESC-USP: Neuza Celere, Terezinha Coletta, Helena Peres e Elena Luíza, pela ajuda no levantamento e normatização das referências bibliográficas;

Aos Secretários do SEM-EESC: Ana Paula, Cristina, Elizabeth, Margareth e Maranho,, pela presteza no atendimento;

Enfim, a todos aqueles que, de alguma forma, contribuíram para o êxito do presente trabalho. 


\section{SUMÁRIO}

LISTA DE FIGURAS

LISTA DE TABELAS

LISTA DE SÍMBOLOS, ABREVIATURAS E SIGLAS

RESUMO

ABSTRACT

CAPÍTULO 01 - INTRODUÇÃO

1.1 - OBJETIVOS DA PESTIJISA

CAPÍTULO 02 - REVISÁO BIBLIOGRÁFICA

2.1 - BREVE HISTÓRICO DOS MOTORES A GÁS 5

2.2 - PRODUÇÃO E RESERVAS DE GÁS NATURAL 6

2.3 - CARACTERISTICAS DO GÁS NATURAL 9

2.4 - ARMAZENAMENTO E ABASTECIMENTO 19

2.5 - SISTEMAS DE FORMAÇÃO DE MISTURA 22

2.6 - MOTORES DE CARGA ESTRATIFICADA 24

2.7 - CONVERSÃO DE MOTORES PARA GÁS NATURAL 32

CAPÍTULO 03 - SISTEMAS DE INJEÇÃO ELETRÔNICA DE COMBUSTIVEL PARA MOTORES DE IGNIÇÃO POR CENTELHA

3.1 - SISTEMAS DE CONTROLE INTEGRADOS

3.2 - INJEÇÃO ELETRÔNICA DE COMBUSTÍVEL

3.3 - SISTEMA DE INJEÇÃO MULTI-POINT (MPI)

3.3.1 - Estratégias de Injeção Multi-Point (MPI)

3.4 - SISTEMA DE INJEÇÃO SINGLE-POINT (SPI) 
CAPÍTULO 04 - ANÁLISE TERMODINÂMICA DO MOTOR

4.1 - CICLO PADRÃO DE AR OTTO

4.2 - MÁXIMO TRABALHO DE UM MOTOR DE COMBUSTÃO INTERNA

4.3 - BALANÇO TÉRMICO DE UM MOTOR DE COMBUSTÃO

CAPÍTULO 05 - O RENDIMENTO VOLUMÉTRICO

5.1 - CONSIDERAÇÕES PRELIMINARES

5.2 - DEFINIÇÕES E CONDIÇÕES DE REFERÊNCIA

5.3 - O PROCESSO DE ADMISSÃO IDEAL

5.4 - OS PROCESSOS DE ADMISSÃO E EXAUSTÃO EM MOTORES DE QUATRO TEMPOS

5.5 - VARIÁVEIS QUE INFLUENCIAM O RENDIMENTO VOLUMÉTRICO

5.6 - EFEITOS QUASI-ESTÁTICOS

5.6.1 - Eficiência Volumétrica d) Ciclo Padrão ArCombustível

5.6.2 - Efeitos da Razão Ar-Combustível, Fase e Composição do Combustível

5.6.3 - Efeitos da Fração do Combustível Vaporizado, do Calor de Vaporização e da Transferência de Calor

5.6.4 - Efeitos da Razão de Compressão e Razão da Pressão de Admissão e Exaustão

5.7 - EFEITOS DINÂMICOS E QUASI-ESTÁTICOS COMBINADOS

5.7.1 - Perdas por Friç̧ão

5.7.2 - Efeito RAM

5.7.3 - Fluxo Reverso na Admissão

5.7.4 - Tuning

5.7.5 - Efeitos da Velocidade, Área da Válvula e do Tempo

5.8 - EFICIÊNCIA VOLUMÉTRICA REDUZIDA AS CONDIÇÕES PADRÃO

5.9 - RELAÇÃO ENTRE O RENDIMENTO VOLUMÉTRICO E OUTROS PARÂMETROS DE DESEMPENHO DO MOTOR 
CAPÍTULO 06 - MATERIAIS E MÉTODOS

6.1 - PROCEDIMENTOS EXPERIMENTAIS 100

6.2 - DESCRIÇÃO DOS EQUIPAMENTOS E INSTALAÇÕES 110

6.2.1 - Sistema de Injeção Direta de Gás Natural 111

6.2.2 - Módulo Eletrônico de Controle da Injeção 116

6.2.3 - Sistema de Ignição Transistorizada $\quad 118$

6.2.4 - Sistema Gravimétrico de Medição do Consumo de Gás Natural

CAPÍTULO 07 - RESULTADOS E ANÁLISE

7.1 - SISTEMA DE INJEÇÃO DIRETA DE GÁS NATURAL 138

$\begin{array}{ll}7.2 \text { - DESEMPENHO DO MOTOR } & 140\end{array}$

CAPÍTULO 08 - CONCLUSÕES E SUGESTÕES 158

$\begin{array}{ll}8.1 \text { - CONCLUSÕES } & 158\end{array}$

$\begin{array}{ll}8.2 \text { - SUGESTÕES } & 160\end{array}$

REFERÊNCIAS BIBLIOGRÁFICAS

$\begin{array}{lr}\text { LITERATURA CONSULTADA } & 170\end{array}$

ANEXO A - FÓRMULAS UTILIZADAS PARA DETERMINAÇÃO DOS PARÂMETROS DE DESEMPENHO DO MOTOR DE TESTES APRESENTADAS NAS PLANILHAS 7.1 A 7.8

ANEXO B - EQUAÇÕES GERAIS APLICADAS EM SISTEMAS TERMODINÂMICOS ABERTOS 


\section{LISTA DE FIGURAS}

FIGURA 2.1 - Distribuição das Reservas de Gás Natural Comprovadas no Mundo.

FIGURA 2.3 - Distribuição Geográfica das Jazidas de Gás Natural e Rede de Gasodutos no Brasil.

FIGURA 2.4 - Curvas de Temperatura adiabática de Chama para a Gasolina e o Metano em função da Razão Equivalente.

FIGURA 2.5 - Diagrama Esquemático de um Posto de Abastecimento de Veículos com GNC.

FIGURA 2.6 - Sistema de Combustão Hesselman

FIGURA 2.7 - Motores de Carga Estratificada de Produção Comercial: O Sistema de Combustão Controlada TCCS da TEXACO e o Sistems FM d MAN.

FIGURA 2.8 - Esquema de um Motor Ciclo Otto de Carga Estratificada e Ignição por Tocha.

FIGURA 2.9 - Diagrama Típico de um Sistema de Conversão Mecânico Bicombustivel para uso do GNC ou GLP.

FIGURA 2.10 - Diagrama Típico de um Sistema de Conversão Eletrônico Bicombustivel para uso do GNC ou GLP.

FIGURA 2.11 - Curvas de Desempenho de motor operando com Gasolina e GNC em regime de Plena Carga.

FIGURA 3.1 - Sistema de Controle Integrado Típico de um Motor.

FIGURA 3.2 - Configuração de uma ECU.

FIGURA 3.3 - Curva Típica de Corte de Combustível em Altas Rotações do Motor.

FIGURA 3.4 - Taxa de Purificação dos Gases de Exaustão Típica de um Catalisador de 3-Vias.

FIGURA 3.5 - Sistema de Retroalimentação com Sensor Lambda. 
FIGURA 3.6 - Controle Típico de um Sistema de Recirculação de Gases de Exaustão.

FIGURA 3.7 - Projeção de Utilização dos Sistemas de Formação de Mistura em Carros de Passeio na Europa.

FIGURA 3.8 - Tempos de Resposta Típicos dos Sistemas de Injeção Eletrônica de Combustivel e Carburador Versus o Tempo de Resposta Requerido para Boa Dirigibilidade e Emissões Aceitáveis

FIGURA 3.9 - Diagrama Esquemático de um Sistema de Injeção MultiPoint

FIGURA 3.10 - Sistema Típico de Gerenciamento Eletrônico de Injeção Multi-point (MPI).

FIGURA 3.11 - Circuito de Combustível de um Sistema de Injeção Multi-Point (MPI).

FIGURA 3.12 - Montagem Típica de uma Válvıla Injetora de um Sistema Multi-point (MPI), com Indicação ds Gradiente de Pressão Entre a Linisa cie Cumususívei e o Coletor de Admissão.

FIGURA 3.13 - Estratégias de Injeção Simultânea, em Grupo e Seqüencial para Sistemas de Injeção Multi-point (MPI)

FIGURA 3.14 - Diagrama Esquemático de um Sistema de Injeção Single Point

FIGURA 4.1 - Diagramas de Pressão versus Volume $(\mathrm{P} \times \mathrm{V})$ e Temperatura versus Entropia ( $\mathrm{T} \times \mathrm{S})$ para o Ciclo Padrão de $\mathrm{Ar}$ Otto.

FIGURA 4.2 - Curvas de Rendimento Térmico versus Razão de Compressão...

FIGURA 4.3 - Volume de Controle para um Motor de Combustão Interna, com Indicação dos Fluxos de Energia e Massa Através das Fronteiras.

FIGURA 5.1 - Condições de Referência para Determinação do Rendimento Volumétrico.

FIGURA 5.2 - Processos de Admissão e Exaustão de um Motor de Ignição por Centelha de 4 tempos. (a) Pressões Médias na Admissão; (b) Diagramas de Válvulas e Pressão versus Volume; (c) Sistema de Exaustão; (d) Pressões Indicadas (p) e Levantamento de Válvulas em Função do Ângulo n Árvore de Manivelas( $(\theta)$. A 
Linha cheia é a Plena Carga e a Pontilhada em Regime Cargas Parciais.

FIGURA 5.3 - Efeito do Vapor do Combustivel na Pressão Parcial do Ar. Razão da Pressão de Admissão do $\operatorname{Ar}\left(P_{a, i}\right)$ para Pressão de Admissão da Mistura $\left(P_{i}\right)$ Versus Razão Equivalente $(\phi)$ para Vapor de Iso-octano, propano, metano, vapor de metanol e hidrogênio

FIGURA 5.4 - Efeito da Razão de Pressões de Admissão e Escape na Eficiência Volumétrica do Ciclo Ideal.

FIGURA 5.5 - Perdas de pressão no sistema de admissão de um motor de ignição por centelha em regime permanente, curso $=89 \mathrm{~mm}$ e diâmetro $=84 \mathrm{~mm}$.

FIGURA 5.6 - Pressão no coletor de exaustão em função da carga e velocidade de um motor de ignição por centelha de 4 cilindros.

FIGURA 5.7 - Pressão instantânea no coletor de admissão e exaustão de um motor de ignição por centelha de 4 tempos. $P_{1}=$ coletor de admissão; $P_{2}=$ coletor de exaustão

FIGURA 5.8 - Eficiência Volumétrica Versus Velocidade Média do Pis.ão de um Motor de 04 Cilindros com Injeção Indireta de Diesel e um Motor de 06 Cilindros de Ignição por Centelha.

FIGURA 5.9 - Efeitos de diferentes fenômenos de escoamento do ar na eficiência Volumétrica do motor em função da velocidade. A linha sólida é a curva final de $\eta_{v}$ versus a rotação.

FIGURA 6.1 - Diagrama Esquemático de Montagem dos Equipamentos de Controle do Motor de Testes no Dinamômetro.

FIGURA 6.2- Diagrama esquemático do sistema de controle e monitoramento da injeção direta de gás natural, do monitoramento da ignição e pressão indicada do motor de testes.

FIGURA 6.3 - Diagrama Esquemático do Conjunto de Injeção Direta de Gás Natural a Baixas Pressões.

FIGURA 6.4 - Diagrama de Corpo Livre da Válvula de Retenção do Conjunto de Injeção Direta de Gás Natural.

FIGURA 6.5 - Diagrama Elétrico da Unidade de Gerenciamento Eletrônico da Injeção de Gás natural. 
FIGURA 6.6 - Diagrama Esquemático do Sistema de Ignição transistorizada com Mecanismo de Controle do Avanço da Centelha.

FIGURA 6.7 - Sistema de Medição do Consumo GN

FIGURA 6.8 - Vista Geral do Motor no Dinamômetro

FIGURA 6.9 - Bancada de Controle e Monitoramento

FIGURA 6.10 - Conjunto de Injeção direta de Gás natural

FIGURA 6.11 - Vista Lateral dos Componentes do Conjunto de Injeção Direta de GN.

FIGURA 6.12 - Vista de Topo dos Componentes do Conjunto de Injeção Direta de GN.

FIGURA 6.13 - Vista Superior da Unidade de Gerenciamento Eletrônico da Injeção de GN com Sinais de Monitoramento da Injeção e Ignição Transistorizada do Motor de Testes.

FIGUR̃ ú 14 - Vrisia inferior do Sistema de Controle da Injeção de Gás natural e Monitoramento da Injeção e Ignição.

FIGURA 6.15 - Sistema de Aquisição de Dados.

FIGURA 6.16 - Vista Superior do Motor de Testes.

FIGURA 6.17 - Sistema de Ignição Transistorizada.

FIGURA 6.18 - Vista Posterior do Motor.

FIGURA 6.19 - Sistema de Medição do Consumo de Gás natural

FIGURA 6.20 - Vista do Dinamômetro Corrente de Foucaut.

FIGURA 6.21 - Sistema de Aquecimento de Gás Natural para o Motor 


\section{LISTA DE TABELAS}

TABELA 2.1 - Reservas de Gás Natural e Petróleo. 6

TABELA 2.2 - Características Físico-Químicas do GN em Várias Regiões do Brasil.

TABELA 2.3 - Propriedades do Gás Metano e da Gasolina......................... 13

TABELA 6.1 - Especificações do Motor. 105

TABELA 6.2 - Testes de Avaliação dos Componentes............................... 106

TABELA 6.3 - Especificações do GNC ............................................... 108

PLANILHA 7.1 - Ensaio nº 01 de Plena Carga com Carburação de Gasolina... 152

PLANILHA 7.2 - Ensaio nº 02 de Plena Carga com Carburação de Gasolina.... 153

PLANILHA 7.3 - Ensaio nº 03 de Plena Carga com Injeção Indireta de GN..... 154

PLANILHA 7.4 - Ensaio nº 04 de Plena Carga com Injeção Indireta de GN..... 155

PLANILHA 7.5 - Ensaio nº 05 de Plena Carga com Injeção Direta de GN....... 156

PLANILHA 7.6 - Ensaio nº 06 de Plena Carga com Injeção Direta de GN....... 157

TABELA C-1 - Faixa de Incerteza para as Variáveis Independentes do Motor.. 193

TABELA C-2 - Faixa de Incerteza para as Variáveis Dependentes do Motor.... 194 


\section{SÍMBOLOS}

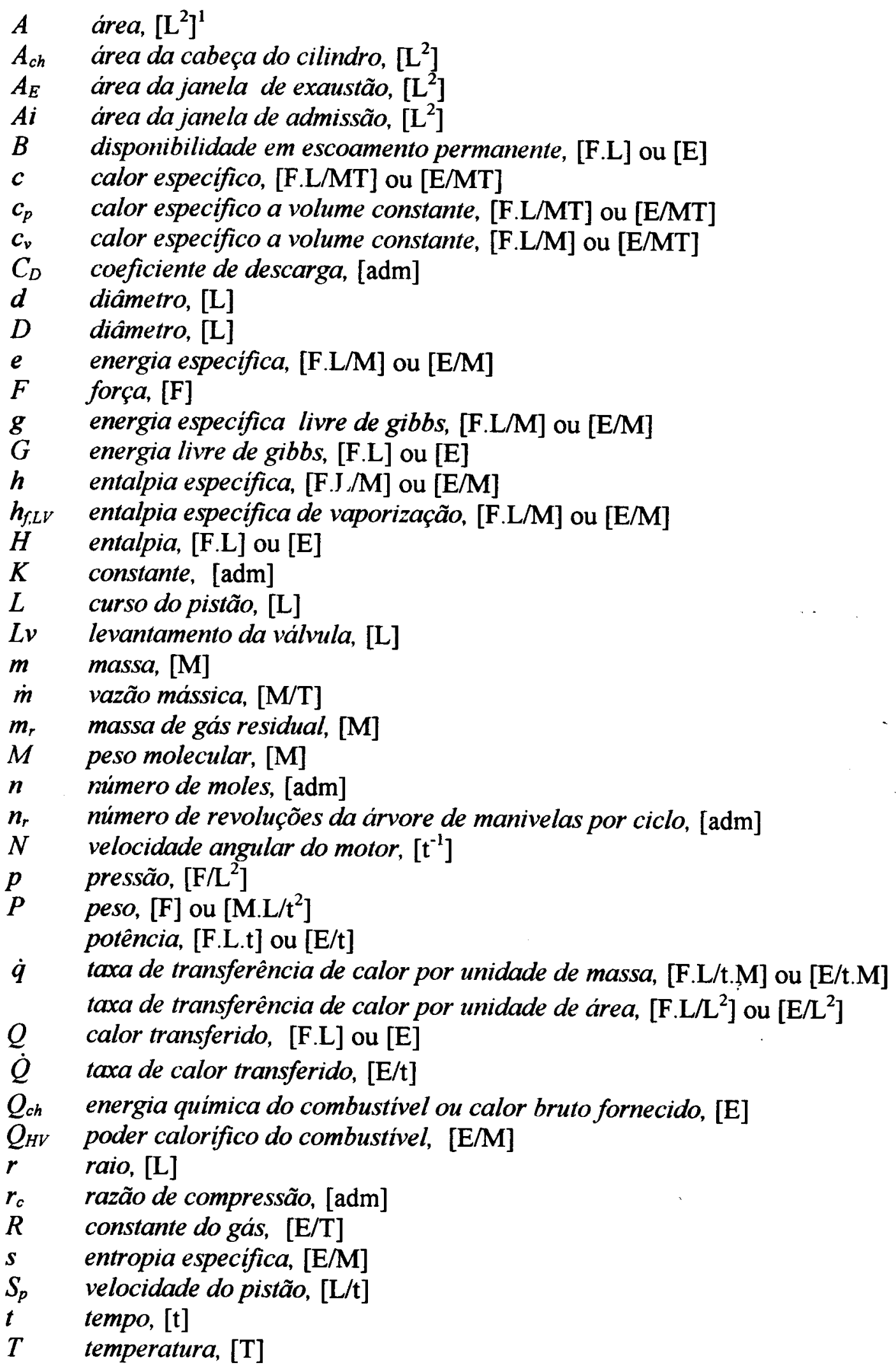

\footnotetext{
${ }^{1}$ Dimensões Fundamentais: Força [F]; Massa [M]; Comprimento [L]; Tempo [t]; Temperatura [T];
} [E] energia: ângulo trigonométrico $(\theta)$;Admensional [adm] 


\section{SÍMBOLOS}

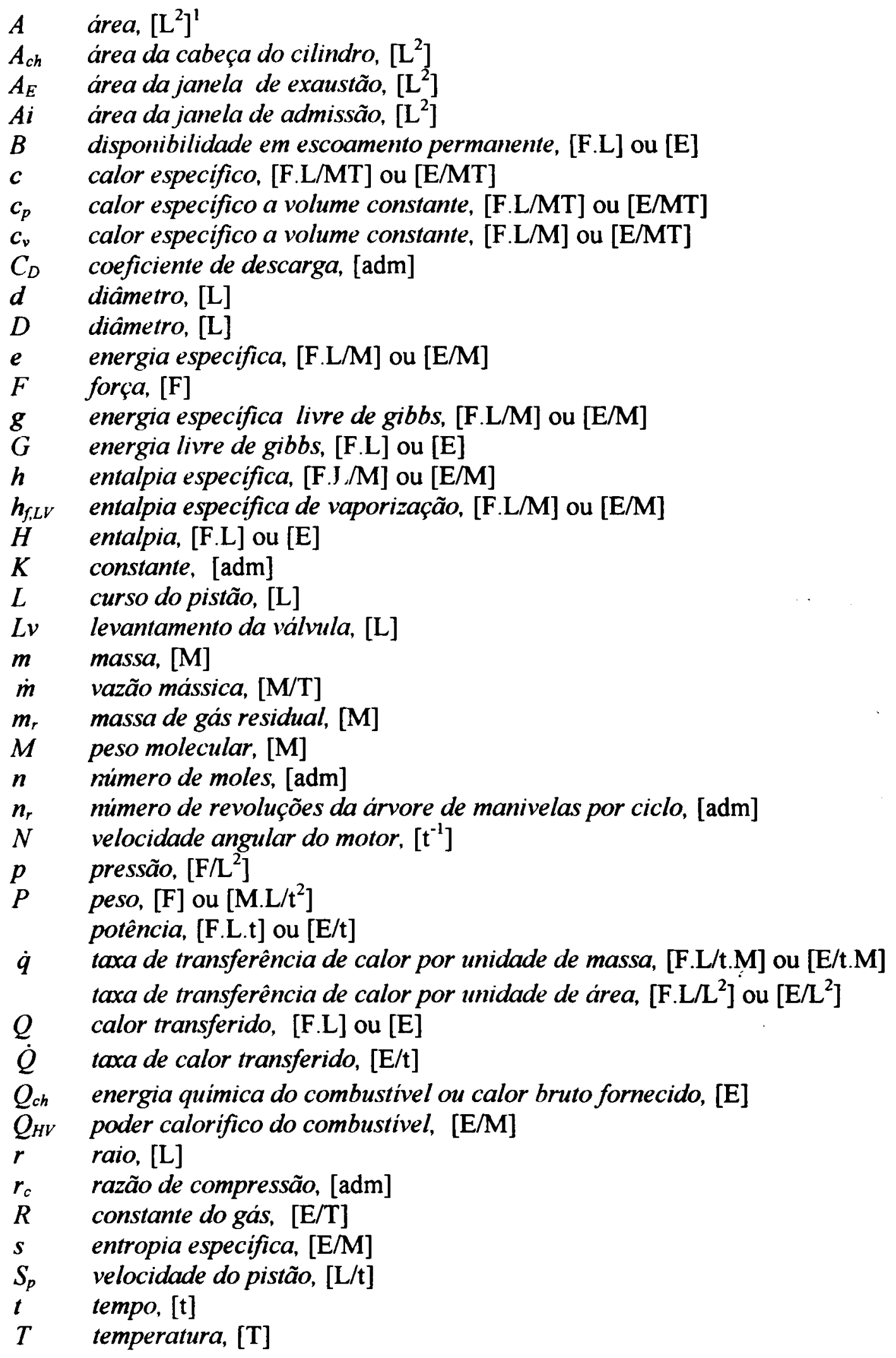

${ }^{1}$ Dimensões Fundamentais: Força [F]; Massa [M]; Comprimento [L]; Tempo [t]; Temperatura [T]; [E] energia: ângulo trigonométrico $(\theta)$;Admensional [adm] 


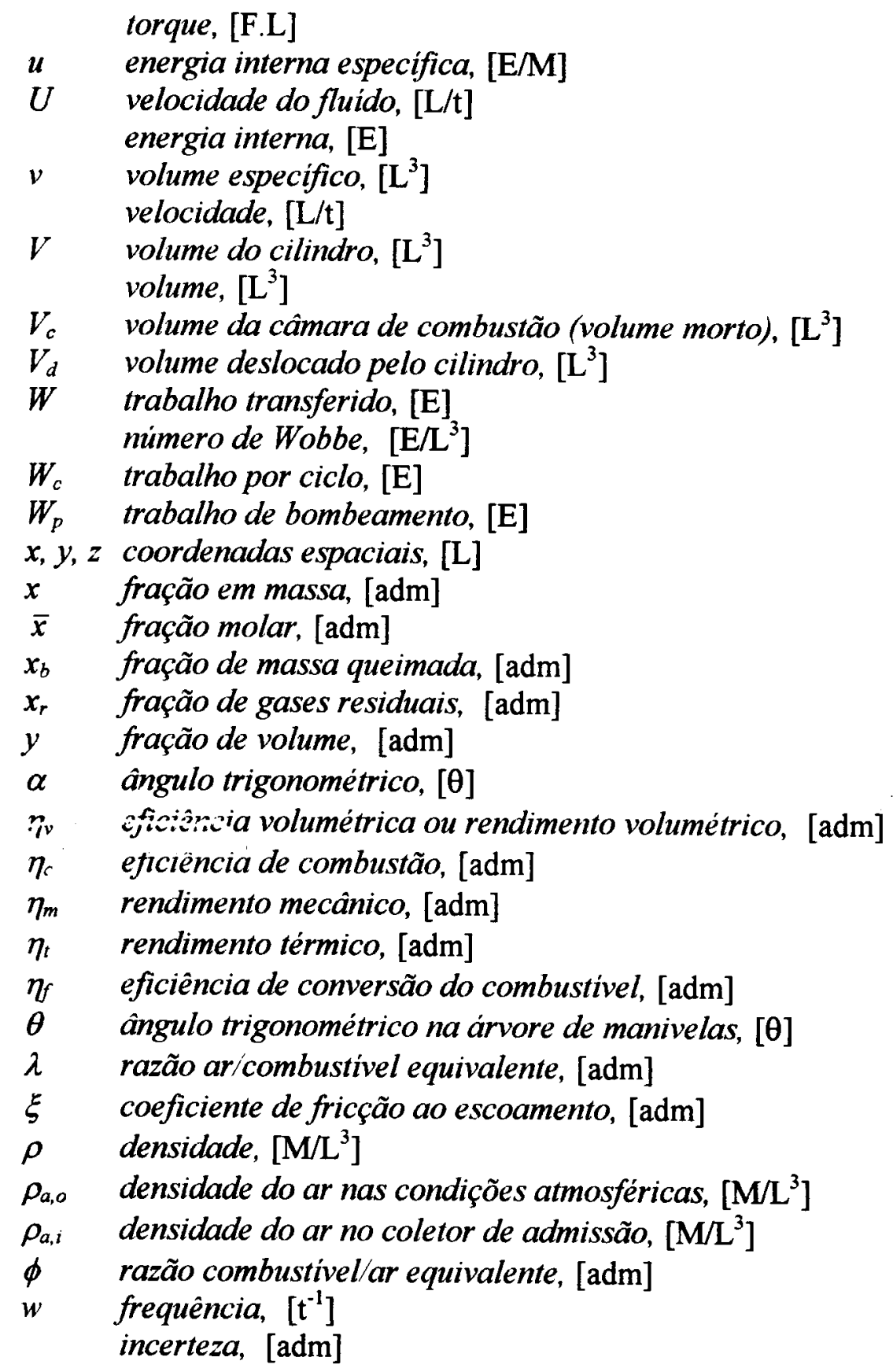




\section{SUBSCRITO}

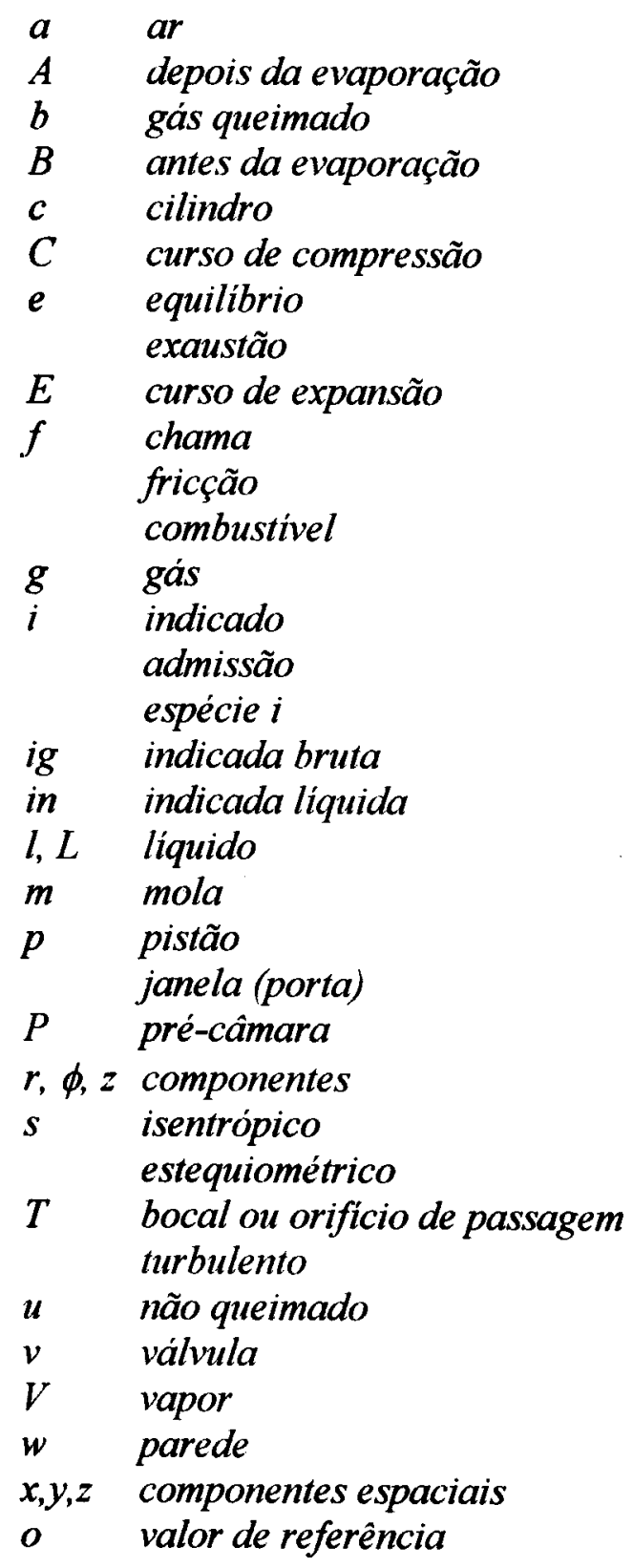




\title{
NOTACÃO
}

\author{
$\Delta$ diferença \\ - diferença ou valor médio \\ - valor aproximado \\ - taxa de variação no tempo
}

\section{ABREVIAÇÕES}

\begin{tabular}{|c|c|}
\hline$A / F$ & razão ar-combustivel \\
\hline$B C, A B C, B B C$ & ponto motor inferior, depois do $B C$, antes do $B C$ \\
\hline CFI & injeção central de combustivel \\
\hline$C I D$ & conjunto de injeção direta de gás natural \\
\hline$E C U$ & unidade de controle eletrônico \\
\hline$E G R$ & recirculação dos gases de exaustão \\
\hline$E P C$ & fechamento da janela de exaustão \\
\hline EPO & abertura da janela de exaustão \\
\hline$E V C$ & fechamento da válvula de exaustão \\
\hline EVO & 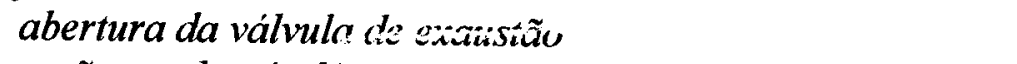 \\
\hline$F / A$ & razão combustiveliar \\
\hline$G N$ & gás natural \\
\hline GNC & gás natural comprimido \\
\hline$I P C$ & fechamento da janela de admissão \\
\hline$I P O$ & abertura da janela de admissão \\
\hline$I V C$ & fechamento da válvula de admissão \\
\hline IVO & abertura da válvula de admissão \\
\hline$M E C$ & módulo eletrônico de controle \\
\hline mep & pressão média efetiva \\
\hline$M P I, M F P I$ & multi-point fuel injection (injeção múltipla de combustivel) \\
\hline $\begin{array}{ll}s f c \\
S P I\end{array}$ & consumo especifico de combustivel \\
\hline $\begin{array}{l}S P I \\
T B I\end{array}$ & single-point injection (injeção central de combustivel) \\
\hline$T B I$ & $\begin{array}{l}\text { throttle body injection (injeção de combustivel no corpo da } \\
\text { válvula) }\end{array}$ \\
\hline $\begin{array}{l}T C, A T C, B T C \\
V C\end{array}$ & $\begin{array}{l}\text { ponto morto superior, depois do } T C \text {, antes do } T C \\
\text { volume de controle }\end{array}$ \\
\hline VEIC & válvula elétrica injetora de combustivel \\
\hline
\end{tabular}




\section{RESUMO}

BARBOSA, C.R.F. Desempenho de um motor ciclo Otto com injeção direta de gás Natural. São Carlos, 1997, 197p. Tese (Doutorado) - Escola de Engenharia de São Carlos - Universidade de São Paulo.

Um motor ciclo Otto funcionando com injeção direta de gás natural, durante o curso de admissão, foi submetido a ensaios de plena carga em um dinamômetro corrente de Foucaut. Os resultados obtidos revelam um aumento de eficiência volumétrica do motor com injeção direta de GNC em relação à injeção indireta de GNC realizada no coletor de admissão, a montante da borboleta do acelerador. Na adaptação para operação com injeção direta de gás natural, as características técnicas do motor não foram alteradas. Um conjunto de injeção direta de gás natural, com gerenciamento eletrônico, foi inserido no cabeçote do motor de testes. Mantendo-se a pressão da linha de alimentação de gás natural constante, através de uma válvula redutora, a quantidade de combustivel injetada no cilindro foi ajustada variando-se o tempo de abertura da válvula elétrica injetora de combustivel. Dados de desempenho do motor são comparados, destacando-se os fatores que contribuem para este aumento relativo de eficiência volumétrica. Discute-se ainda, modificações a serem implementadas no motor visando maximizar sua potência com injeção direta de gás natural.

PALAVRAS CHAVE: Motor Ciclo Otto, Injeção Direta, Gás Natural 


\begin{abstract}
BARBOSA, C.R.F. Desempenho de um motor ciclo Otto com injeção direta de gás natural. São Carlos, 1997, 197p. Tese (Doutorado) - Escola de Engenharia de São Carlos, Universidade de São Paulo.
\end{abstract}

Otto cycle engine direct injection natural gas, during the inlet stroke, submitted to runs with full power in a Foucaut dynamometer. The results obtained show a increase in the volumetric efficiency of the engine with natural gas direct injoction whon cumpared which natural gas injection apllied in the inlet manitold, upstream of the throttle butterfly. In the conversion to natural gas direct injection, the technical characteristics of the were not changed. A kit for natural gas direct injection, with eletronic managment, was located on the cylinder head of the test engine. Maintaining the pressure constant in the natural gas fuel line, using a reduction valve. The mass of fuel injected into the cylinder was regulated, varying the opening time of the solenoid valve fuel injector. Engine performance data is compared, emphasizing the factors that contribute to this increase in relative volumetric efficiency. Modifications to be made to maximize the power of the engine with natural gas direct injection.

KEY WORKS: Otto Cycle Engine, Direct Injection, Natural Gas 


\section{CAPÍTULO 01 - INTRODUÇÃO}

Nos últimos anos, as possibilidades cada vez mais evidentes de escassez e flutuações de preços dos combustiveis derivados do petróleo aliadas as preocupações de preservação ambiental contribuíram decisivamente para o aumento da utilização de combustiveis alternativos, menos poluentes, em motores veiculares.

Neste contexto, o gás natural. predominantemente metano, desponta como uma das alternativas mais pron nssoras e atrativas em virtude da sua disponibilidade, custo e excelentes propriedades termodinâmicas. Além disso, o programa de gás natural veicular vem crescendo ano após ano no cenário mundial. Esta característica, o distingue dos álcoois etanol e metanol que ficaram restritos respectivamente ao Brasil e América de Norte. MAXWELL (1995)

Os primeiros motores movidos a gás que se tem notícia, surgiu praticamente com o advento do motor de ignição por centelha e utilizavam o carburador para realizar a formação da mistura ar-gás no duto de admissão. Hoje, a grande utilização e produção em escala industrial de veículos a gás natural já é uma realidade no Brasil e no mundo. Recentemente, o governo brasileiro apostando no programa do gás natural automotivo, através de decreto presidencial em janeiro de 1996, liberou o uso do GNC para quaisquer fins veiculares. VOLKSWAGEN (1996) 
Embora rotulados como motores de alto desempenho e ecológicos, os modernos motores do ciclo Otto, com injeção eletrônica de gás e aspiração natural, ainda apresentam uma baixa eficiência volumétrica com queda de até $15 \%$ em relação a alimentação com gasolina, que limita sua potência, e emitem uma carga significativa de óxidos de nitrogênio (NOx). MAXWELL (1995)

Nos motores de ignição por centelha em que a relação custo-beneficio é favorável, tecnologias de supercarregamento, de distribuição multiválvulas (16 válvulas), de sistemas com tempo de acionamento de válvulas variável (VVT) e de injeção direta de combustível, vem sendo utilizadas em escala de produção para otimizar a eficiência volumétrica e o desempenho dos motores. HATANO et al (1994), LENZ (1992) e HEYWOOD (1988)

O desenvolvimento e aplicação de sistemas de injeção indireta com gerenciamento eletrônico em motores veiculares obteve notáveis avanços. Sua ampla utilização deve-se basicamente ao barateamento dos componentes eletrônicos e melhor gerenciamento da mistura ar-combustível, o qual proporciona ao motor um melhor desempenho e redução dos índices de emissões quando comparado com os tradicionais carburadores. PASSARINI (1993)

Atualmente no Brasil, com exceção de alguns modelos populares, os veículos são produzidos com injeção eletrônica.

Processos de recirculação dos gases queimados (EGR), queima de mistura pobre "lean burning", ou ainda injeção de vapor de água no coletor de admissão, com ou sem o uso de catalisadores, são exemplos de algumas tecnologias já disponíveis e que eventualmente podem ser adotadas com o propósito de reduzir as temperaturas 
máximas do ciclo e por conseguinte a carga de $\mathrm{NO}_{\mathrm{x}}$. Porém, tais processos quando empregados isoladamente, atuam no sentido de reduzir as potências máximas do motor. PAUL (1995), BOSCH (1994) e LENZ (1992)

Neste trabalho é feito um estudo experimental sobre injeção direta de gás natural a baixas pressões, como forma de melhorar o carregamento de ar do cilindro e conseqüentemente aumento da potência do motor. $\mathrm{Na}$ injeção direta a baixas pressões, a própria pressão de armazenamento do gás é utilizada para realizar a injeção do combustivel gasoso no cilindro do motor, com maior utilização da carga útil de gás disponivel nos cilindros de armazenamentc. 


\section{1 - OBJETIVOS DA PESQUISA}

a) Desenvolver um sistema de injeção direta com gerenciamento eletrônico, capaz de injetar gás natural a baixas pressões diretamente na câmara de combustão de um motor ciclo Otto;

b) Avaliar o desempenho de um motor ciclo Otto funcionando com o sistema de injeção proposto;

c) Comparar o desempenho do motor de testes operando com injeção direta em relação à injeção indireta de gás natural no coletor de admissão e com carburação convencioniaí úe yasolina. 


\section{CAPÍTULO O2 - REVISÃO BIBLIOGRÁFICA}

\section{1 - BREVE HISTÓRICO DOS MOTORES A GÁS}

A utilização de combustiveis gasosos em motores de combustão interna é uma prática bastante antiga. Em 1801, na França, foi requerida uma patente para utilização de uma mistura de gases equivalentes ao gasogênio em motores. Motores estacionários funcionavam com gás de esgoto na Índią a nạ Inglaterra no início do século XIX. Na década de 20, o gás natural é extensivitinente utilizado em motores no norte da Itália. Em 1935, na Alemanha, surgiu o primeiro veículo alimentado com combustível gasoso. BET (1991). Em 1991, a frota mundial de veículos GNC era cerca de 700 mil, sendo aproximadamente 300.000 na Itália, 150.000 na Nova Zelândia, 100.000 no Canadá e 85.000 veículos na Argentina. Nesta época, o Brasil tinha apenas 360 veiculos a GNC. FONTES JR. (1994) e WANG et al (1993) . Em 1995, a frota mundial de veículos a GNC era cerca de 800.000 veículos. MAXWELL (1995). Em 1996, a frota brasileira de veículos movidos a GNC era de 11.000 unidades, e as expectativas é que até o ano 2000, este número salte para 100 mil unidades. Em janeiro de 1996, o Presidente Fernando Henrique assinou decreto liberando o uso do GNC em qualquer veículo. PINCIGHER (1996) e VOLKSWAGEN (1996) 


\section{2 - PRODUÇÃO E RESERVAS DE GÁS NATURAL}

A Tabela 2.1 compara as reservas de gás natural (GN) e petróleo e também as perspectivas de escassez destas reservas. As reservas comprovadas de GN até janeiro de 1995 totalizavam cerca de 141 trilhões de normal metros cúbicos. As projeções indicam que as reservas de GN devem durar muito mais que as reservas de petróleo. TOKIO GÁS (1996), ARPEU (1995) e TOKIO GÁS, (1995).

TABELA 2.1 - Reservas de Gás Natural e Petróleo.

\begin{tabular}{|c|c|c|}
\hline & GÁS NATURAL & PE TKÚLEU \\
\hline $\begin{array}{c}\text { RESERVAS } \\
\text { COMPROVADAS }\end{array}$ & 141 Trilhões de N.m $\mathrm{m}^{3}$ & $\begin{array}{l}1 \text { Trilhão de Barris } \\
\text { (equiv. a } 150 \mathrm{~N} \cdot \mathrm{m}^{3} \text { de GN) }\end{array}$ \\
\hline $\begin{array}{l}\text { DURAÇÃO DAS } \\
\text { RESERVAS } \\
\text { COMPROVADAS }\end{array}$ & 65 Anos & 45 Anos \\
\hline $\begin{array}{c}\text { RESERVAS MÁXIMAS } \\
\text { ESTIMADAS }\end{array}$ & 398 Trilhões de $\mathrm{N} \cdot \mathrm{m}^{3}$ & $\begin{array}{l}2 \text { Trilhões de Barris } \\
\text { (equiv. a } 300 \mathrm{~N} \cdot \mathrm{m}^{3} \text { de } \mathrm{GN} \text { ) }\end{array}$ \\
\hline $\begin{array}{c}\text { DURAÇÃO MÁXIMA } \\
\text { DAS RESERVAS } \\
\text { ESTIMADAS }\end{array}$ & 183 Anos & 90 Anos \\
\hline
\end{tabular}

FONTE: Catálogo da TOKYO GÁS (1996) 
As reservas comprovadas de gás natural, ao contrário do petróleo, encontramse mais uniformemente distribuídas no mundo. A Figura 2.1, reproduzida do Catálogo da TOKYO GÁS (1996), ilustra em termos percentuais e em valores absolutos a distribuição destas reservas no mundo.

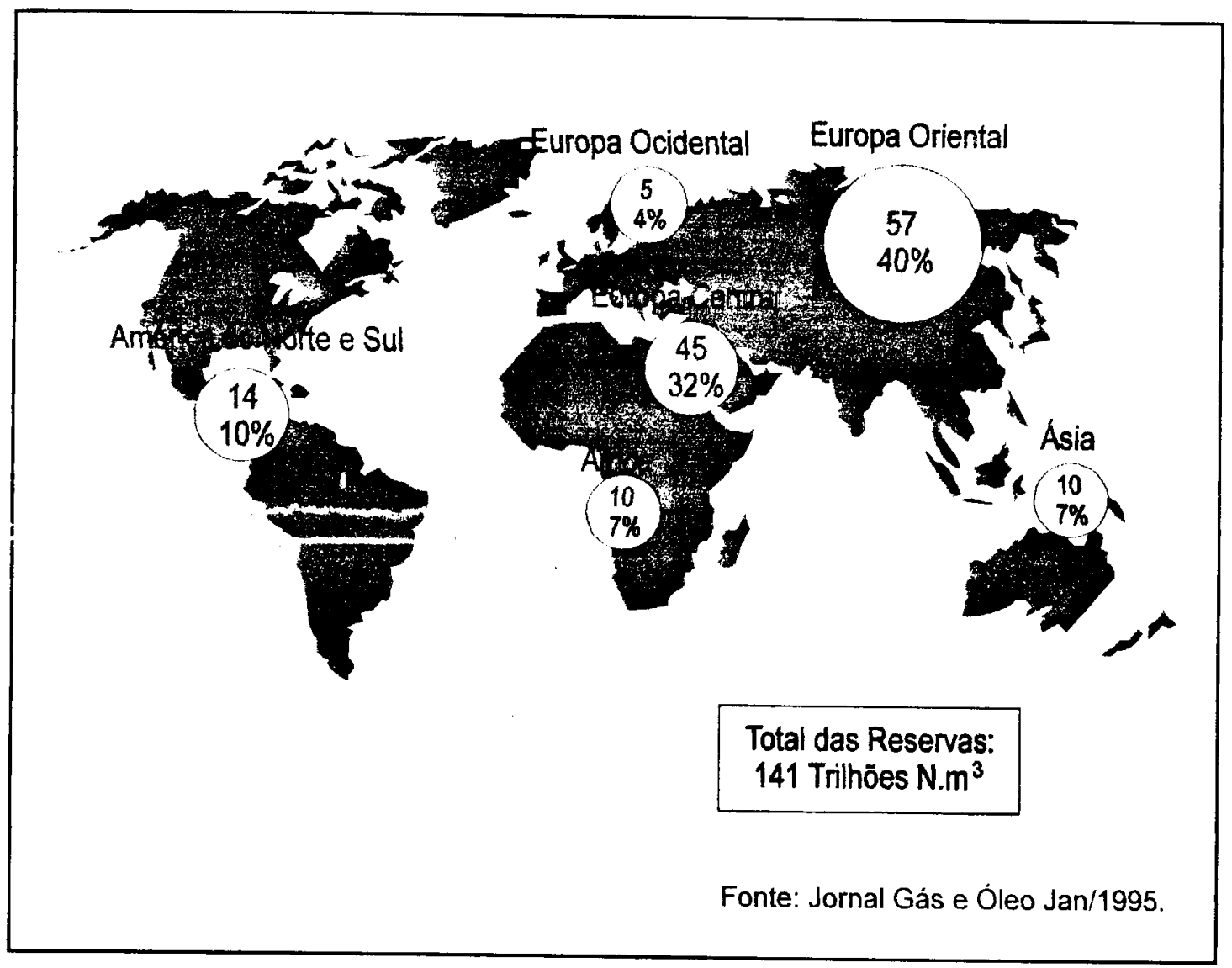

FIGURA 2.1 - Distribuição das Reservas de Gás Natural Comprovadas no Mundo.

O Brasil produz atualmente cerca de 25 milhões de normal metros cúbicos de gás natural por dia. $\mathrm{O}$ mercado de GN no país será ampliado com a entrada em operação do gasoduto Brasil-Bolívia. PROSPECTO DA PETROBRÁS-BR (1996) 
A Figura 2.2, publicada por FRYSZMAN (1992) mostra as reservas comprovadas de gás natural existentes no Brasil, a distribuição geográfica das principais jazidas e sua a infra-estrutura de abastecimento (gasodutos).

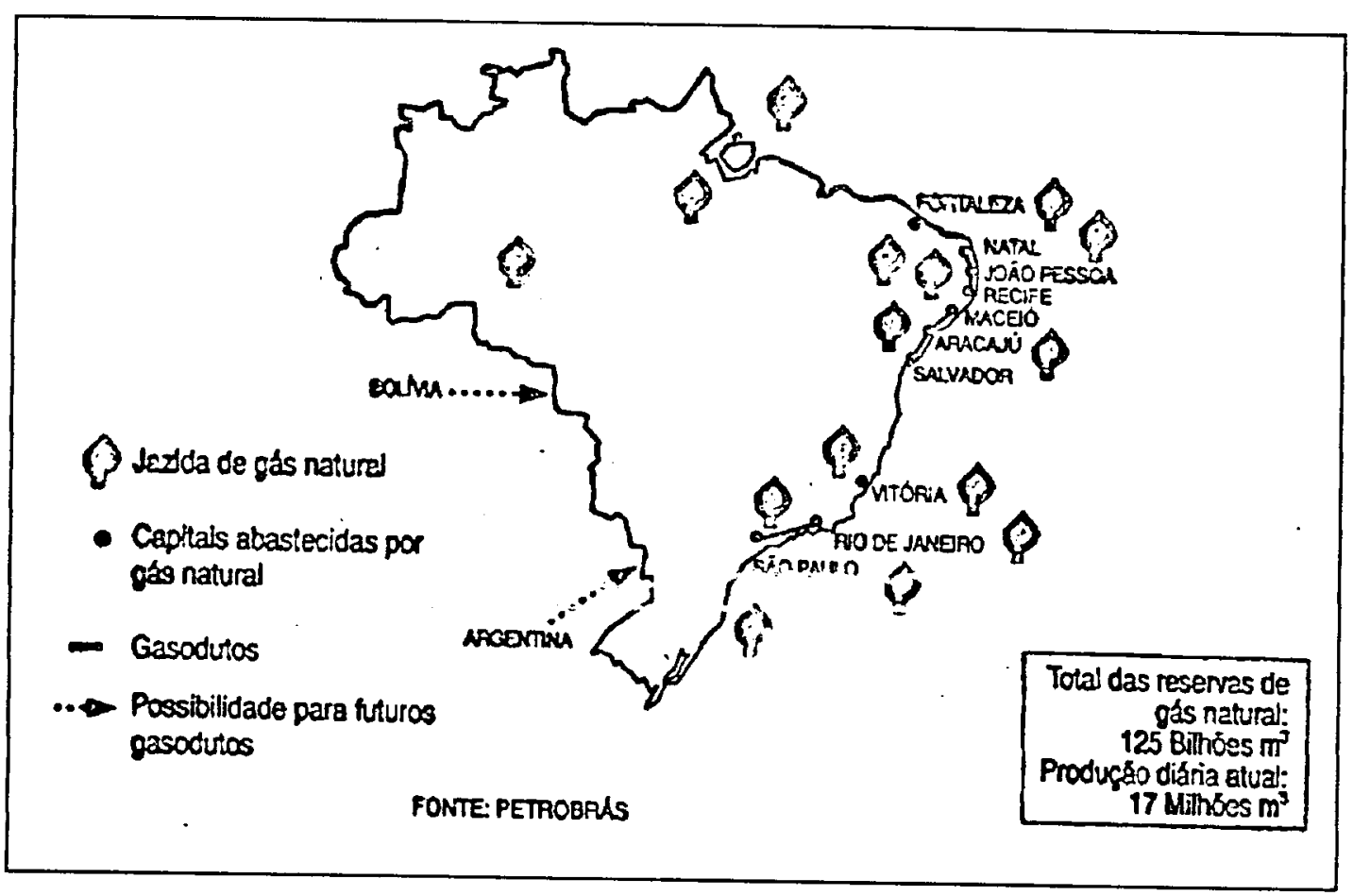

FIGURA 2.2 - Distribuição Geográfica das Jazidas de Gás Natural e Rede de Gasodutos no Brasil.

No Brasil, existem mais de 50 postos de abastecimento de veículos a GNC, espalhados pelas principais capitais do país. Estes postos estão localizados em São Paulo (SP), Rio de Janeiro (RJ), Fortaleza (CE) Salvador (BA), Recife (PE), Natal (RN) Aracaju (SE) e Vitória (ES). O Maior posto de abastecimento de GNC para uso veicular na América Latina está Localizado na cidade de Natal-RN, com capacidade para abastecer simultaneamente 24 veículos. PROSPECTO da PETROBRÁS-BR (1996) e BARBOSA (1990) 


\section{3 - CARACTERÍSTICAS DO GÁS NATURAL}

O gás natural é uma mistura de muitos gases, o principal componente é o gás metano que apresenta concentrações típicas de $89 \%$ a $99 \%$ em volume. Outros hidrocarbonetos em grau decrescente de concentração são etano, propano, butano. Ainda pequenos traços de gases inertes como hidrogênio, nitrogênio e dióxido de carbono podem ser encontrados. MAXWELL (1995) e UNICH et al (1993)

$\mathrm{O}$ gás metano, principal constituinte do gás natural, apresenta uma estrutura molecular muito simples e estável em comparação com a gasolina e o óleo diesel. A estabilidade estrutural significa maior dificuldade de oxidação, baixa reatividade fotoquímica e alto índice de octanas, requerendo portanto altas energia d!e ignição para combustão. A baixa reatividade foquímica, por sua vez, expressa a dificuldade de degradação das moléculas de metano, pela ação da luz solar. JOSSON (1992)

O gás natural pode ser encontrado na natureza de forma associada ou não ao petróleo. No Brasil, as maiores reservas de GN são do tipo associado ao petróleo. As caracteristicas do gás natural para fins industriais variam consideravelmente de região para região, sendo função da fonte de produção (jazida), das características da unidade de processamento do gás natural e das necessidades de consumo. KOSER (1988) e PETROBRÁS (1988)

A Tabela 2.2, publicada pela PETROBRÁS-BR (1989-a) e PETROBRÁS (1989-b), mostra a composição típica do gás natural de várias regiões do Brasil. 
TABELA 2.2 - Características Físico-Químicas do GN em Várias Regiões do Brasil

\begin{tabular}{|l|c|c|c|c|}
\hline PROPRIEDADES & NATAL & R. DE JANEIRO & ARACAJU & SALVADOR \\
\hline $\mathrm{CH}_{4}$ & 84,30 & 86,73 & 89,30 & 87,29 \\
\hline $\mathrm{C}_{2} \mathrm{H}_{6}$ & 10,76 & 9,66 & 7,26 & 9,87 \\
\hline $\mathrm{C}_{3} \mathrm{H}_{8}$ & 0,25 & 1,76 & 0,38 & 0,44 \\
\hline $\mathrm{iC}_{4} \mathrm{H}_{10}$ & $-\cdots$ & 0,30 & 0,02 & -- \\
\hline $\mathrm{nC}_{4} \mathrm{H}_{10}$ & --- & 0,60 & 0,02 & --- \\
\hline $\mathrm{CO}_{2}$ & 3,12 & 0,56 & 1,32 & 0,70 \\
\hline $\mathrm{N}_{2}+\mathrm{O}_{2}$ & 1,57 & 1,29 & 1,74 & 1,70 \\
\hline $\mathrm{PCS}_{\mathbf{K}}$ Kal $\left./ \mathrm{m}^{3}\right)$ & 9.185 & 9.569 & 9.514 & 9.354 \\
\hline Densidade Relativa & 0,645 & 0,629 & 0,613 & 0,620 \\
\hline
\end{tabular}

Obs.: a $20^{\circ} \mathrm{C}$ e $1,033 \mathrm{Kg} / \mathrm{cm}^{2}$, composição vol. (\%).

Segundo WEAVER (1989), grandes quantidades de propano e butano e de hidrocarbonetos mais pesados no gás natural, aumentam a tendência à detonação, enquanto que a presença de maiores quantidades de gases inertes, como o dióxido de carbono $\left(\mathrm{CO}_{2}\right)$ e o nitrogênio $\left(\mathrm{N}_{2}\right)$, agem no sentido contrário, ao mesmo tempo em que diminuem o conteúdo energético do gás natural.

WEAVER (1989) descreve que, para contabilizar os efeitos da variação de composição do gás natural sobre a energia liberada, a indústria do gás estabeleceu um 
índice denominado número de Wobbe. O número de Wobbe é definido como a razão entre o poder calorífico superior (PCS) do gás, em base volumétrica, e a raiz quadrada de sua gravidade específica (densidade) em relação ao ar. LISS \& THRASHER (1991), LASTRES (1987) e KLIMSTRA (1986)

$$
W=\frac{P C S}{\left(\rho_{G N}\right)^{1 / 2}}
$$

onde:

$\mathrm{W}=$ indice de Wobbe a $0^{\circ} \mathrm{C},\left[\mathrm{MJ} / \mathrm{m}^{3}\right]$

$\mathrm{PCS}=$ poder calorifico superior a $0^{\circ} \mathrm{C},\left[\mathrm{MJ} / \mathrm{m}^{3}\right]$

$\rho_{\mathrm{GN}}=$ densidade relativa ào gás, [adim.j

O número de Wobbe é um índice indicativo da capacidade do fluxo de energia de um gás escoando em um orificio ou válvula, mediante um diferencial de pressão. Tal indice é muito útil quando se pretende avaliar equipamentos industriais e motores alimentados com gás natural. LISS \& THRASHER (1991) e WEAVER (1989)

KING (1992) e LISS \& THRASHER (1991) destacam importância da composição do gás sobre o número de Wobbe e a razão ar-combustível. Segundo eles, uma pequena variação da razão ar-combustivel em motores operando com combustão misturas pobres, implica em grandes variações nas emissões de óxidos de nitrogênio $\left(\mathrm{NO}_{\mathrm{X}}\right)$. Outro aspecto ressaltado pelo mesmo autor, é que a composição de gás afeta substancialmente o limite inferior de inflamabilidade, importante nos motores de mistura pobre. 
LISS \& THRASHER (1991) e WEAVER (1989) destacam que, se o gás natural com diferentes números de Wobbe é usado em veículos operando com sistemas de controle do motor em circuito aberto "open-loop", a razão equivalente arcombustivel $(\phi)$ deve ser afetada, com prejuizos para o desempenho do motor e emissão de poluentes.

Porém, para operação com sistemas de controle do motor em circuito fechado "close-loop", as variações no número de Wobbe pouco afetam as condições de operação do motor, uma vez que o módulo de controle eletrônico reage ao sinal do sensor de oxigênio lâmbda $(\lambda)$ ra exaustão e corrige instantaneamente as variações da razão equivalente.

Segundo UNICH et al (1993), devido a aita relação de hıd ogenı/ carbono (H/C) do gás natural (GNC), sua combustão produz cerca de $25 \%$ menos Dióxido de carbono $\left(\mathrm{CO}_{2}\right)$ do que a gasolina e o diesel, considerando-se o mesma eficiência do motor.

De acordo com WEAVER (1989) e LASTRES (1987), o gás natural é um excelente combustivel para motores de ignição por centelha, podendo também ser utilizado em motores do ciclo Diesel.

A Tabela 2.3, publicada por SILVA (1993), apresenta algumas propriedades da gasolina e do gás metano, principal constituinte do gás natural.

Comparando-se as propriedades dos combustíveis apresentados nesta tabela, nota-se que apesar do metano possuir um poder calorifico inferior (PCI) $12 \%$ maior que o da gasolina, o conteúdo energético por unidade de volume da mistura 
estequiométrica de metano e ar é 10\% menor em relação ao da mistura de gasolina-ar. Portanto, para o mesmo motor, o uso do metano provoca uma queda de potência da ordem de $10 \%$ em relação a alimentação com gasolina, em virtude do menor conteúdo energético por unidade de volume da mistura estequiométrica.

TABELA 2.3 - Propriedades do Gás Metano e da Gasolina.

\begin{tabular}{|c|c|c|}
\hline PROPRIEDADE & $\mathrm{CH}_{4}$ & GASOLINA \\
\hline Densidade $\left(\mathrm{Kg} / \mathrm{N} \cdot \mathrm{m}^{3}\right)$ & 0,718 & 5,093 \\
\hline Poder calorífico inferior $(\mathrm{Kcal} / \mathrm{Kg})$ & $\sim 11900$ & $\sim 10600$ \\
\hline Razão ar-combustivel estequiométrica (massa) & 17,2 & 14,9 \\
\hline Razãc ar-çmhustível estequiométrica (volumétrica) & 9,55 & 59,0 \\
\hline Cor $i$ eúdo energético da mistura $\left(\mathrm{Kcal} / \mathrm{N} \cdot \mathrm{m}^{3}\right)$ & $\sim 810$ & $\sim 900$ \\
\hline Calor latente de evaporação (Kcal/Kg) & 122 & $\sim 70$ \\
\hline Temperatura de auto-ignição a 1 atm $\left({ }^{\circ} \mathrm{C}\right)$ & $\sim 650$ & $\sim 500$ \\
\hline Limite de inflamabilidade (\%) & 5,3 a 36 & 1,2 a 6 \\
\hline Energia mínima para ignição (Mj) & 0,28 & 0,25 \\
\hline Velocidade de chama laminar $(\mathrm{cm} / \mathrm{s})$ & 33,8 & $\sim 38$ \\
\hline Temperatura adiabática de chama $\left({ }^{\circ} \mathrm{C}\right)$ & 2227 & 2270 \\
\hline Número de octanas ${ }^{T}$ & 120 & $92 \sim 98$ \\
\hline
\end{tabular}

UNICH et al (1993) afirmam que o conteúdo energético da mistura estequiométrica ar-gás natural é cerca de $10 \%$ menor quando comparada com a gasolina. Tal desvantagem pode ser compensada pelo aumento da eficiência térmica do motor. 
SILVA (1993) descreve que, no caso da gasolina, a maior parte do combustível carburado entra no cilindro do motor na forma de gotículas, sendo vaporizadas na câmara de combustão, após o fechamento da válvula de admissão. Uma pequena parcela de vapor de gasolina entretanto, se forma ainda no coletor de admissão, reduzindo cerca de $1,7 \%$ da aspiração de ar do motor. Portanto, a menor eficiência volumétrica do motor a gás contribui também para redução da sua potência

O gás metano, principal constituinte do gás natural, apresenta temperatura de auto-ignição superior a gasolina e um pouco maior que dos álcoois (etanol e metanol), e seu índice de octanagem, é maior dentre os combustíveis comumente usados em motores Em virtude das suas propriedades anti-detonantes, o gás natural, cuja octanagem RON é da ordem dẹ 130, node ser usado em motores de ignição por centelha com taxas de compı:sião de até 15:1, enquanto que as gasolinas usuais $(\mathrm{RON}=91)$, somente admitem taxas de compressão da ordem de 9:1. A finalidade de se trabalhar com taxas de compressão maiores, está associado no fato de que esta ação aumenta o rendimento térmico do motor. MAXWELL (1995), LENZ (1992) e WEAVER (1989)

A Figura 2.3, publicada por CHAFFIN et al (1991), apresentam as temperaturas de chama adiabática da gasolina e do metano para diferentes razões equivalentes $(\phi)$, na pressão constante de $100 \mathrm{KPa}$ e temperatura inicial de $298 \mathrm{~K}$. Esta figura indica que os picos de pressão e temperatura indicadas de um motor alimentado com gasolina são maiores que alimentado com metano, se a mesma taxa de compressão é usada. Em outras palavras, a combustão do metano é mais "fria" do que a combustão da gasolina nas mesmas condições. 


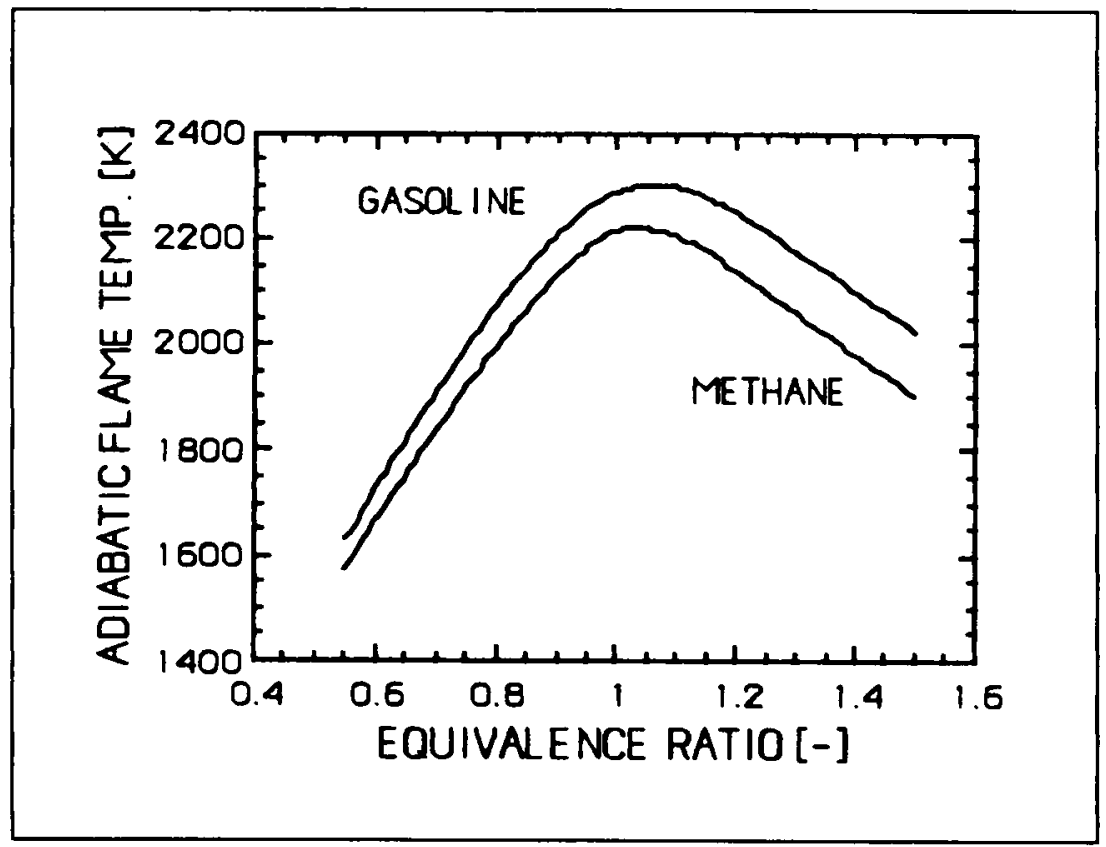

FIGURA 2.3 - Curvas de Temperatura adiabática de Chama para a Gasolina ¿ ¿ Mítetano em Funcào d’a Razão Equivalente.

Entretanto, o processo de combustão em motores exclusivos a gás natural deve fornecer maiores picos de temperatura do que os motores a gasolina, uma vez que utilizam altas taxas de compressão.

Segundo WEAVER (1989), devido as altas energias de ativação do gás natural, sua velocidade de chama laminar é menor que os outros hidrocarbonetos. A baixa velocidade de chama apresentada pelo gás natural resulta em uma longa duração do processo de combustão, sendo necessário um maior avanço de ignição para operação com maior nivel de eficiência. $\mathrm{O}$ avanço de ignição é menor na medida em que se utiliza câmaras de combustão compactas e de alta turbulência e altas taxas de 
compressão, uma vez que estes aumentam as velocidades de chama e diminuem o percurso de chama.

UNICH (1993) e WEAVER (1989) descrevem que em virtude da baixa densidade do gás natural, a mistura de gás natural e ar ocupa um volume cerca de $10 \%$ maior que a mistura estequiométrica de gasolina e ar de mesmo conteúdo energético. Assim, em um motor convencional convertido para operação no modo bicombustível com gás natural, a quantidade de mistura de ar-gás natural que pode ser aspirada, via coletor de admissão, é cerca de $10 \%$ menor do que a mistura argasolina, penalizando substancialmente a potência do motor. Nos motores a gás exclusivo, essa perda de potência é compensada aumentando-se a taxa de compressão do motor e, por conseguinte, a sua eficiência térmica, de modo que resulta em uma maior potência indicada por unidade de mistura queimada.

Para MAXWELL (1995), a menor capacidade de aspiração de ar dos motores alimentados com gás natural ou gases liquefeito do petróleo (GLP) está associada em parte a menor densidade do combustível gasoso e outra parte a restrição imposta pelo conjunto "Kit" de carburação a gás inserido no coletor de admissão, para dosagem do combustivel gasoso.

MAXWELL (1995) afirma que os combustíveis gasosos podem requerer de 4 a $15 \%$ do volume do coletor de admissão. O espaço ocupado pelo combustível reduz a quantidade de ar que entra no motor. Assim, a eficiência volumétrica do motor é reduzida. Esta perda de potência inerente aos combustiveis gasosos não pode ser facilmente superada. A densidade dos combustíveis gasosos no coletor de admissão do motor deve determinar a exata perda de potência. $O$ gás natural, e em menor 
extensão, o GLP são menos densos do que o vapor de gasolina nas condições reinantes no coletor de admissão. Como resultado, esses combustiveis de menor densidade deslocam o ar, reduzindo a pressão parcial do ar na mistura no coletor de admissão, e assim, menor quantidade de ar é introduzida nos cilindros. A magnitude das perdas na potência devido baixa densidade do gás metano pode ser estimada através da equação da combustão, como indicada abaixo:

$$
\begin{aligned}
& \mathrm{CH}_{4}+2\left(\mathrm{O}_{2}+3,77 \mathrm{~N}_{2}\right) \rightarrow \mathrm{CO}_{2}+2 \mathrm{H}_{2} \mathrm{O}+7,55 \mathrm{~N}_{2} \\
& \frac{\text { moles }_{\text {comb. }}}{\text { moles }_{\text {mistura }}}=\frac{1(100)}{1+2(1+3,77)}=9,49 \%
\end{aligned}
$$

Da equação da combustão acima, verifica-se que a relação entre o volume de metano e ว volume de mistura ar-combustível é de 9,5\%. Assim, teoricamente, o gás natural (metano) causa uma perda de potência de aproximadamente $9,5 \%$.

LENZ (1992) e MAXWELL (1995) descrevem que os combustíveis líquidos, quando inseridos via carburação ou injeção indireta, vaporizam parcialmente na corrente de ar no coletor de admissão e entram posteriormente nos cilindros do motor. Essa vaporização absorve energia do meio resfriando a mistura arcombustível. O resfriamento reduz a temperatura da mistura ar-combustível aumentando sua densidade e contribuindo por conseguinte para o aumento da eficiência volumétrica do motor. Os combustíveis gasosos, por outro lado, já existem na forma de vapor superaquecido, não fornecendo esse efeito de resfriamento da mistura ar-combustível. Essa falta de resfriamento nos motores a gás, constitui-se 
numa perda adicional de potência comparada com os motores alimentados com combustiveis líquidos.

Segundo MAXWELL (1995), os álcoois combustíveis tais como metanol e etanol propiciam uma maior refrigeração quando vaporizado do que a gasolina. Essa refrigeração adicional, aumenta a eficiência volumétrica, e portanto, tende a aumentar a potência de eixo do motor.

A uso do gás natural em motores de ignição por centelha é mais seguro e apresenta algumas vantagens quando comparado aos combustíveis convencionais devido as seguintes características: PETROBRÁS-BR (1989-a)

- O metano possui a maior relação hidrogênio/carbonn (1:4) dentre os combustíveis hidrocarbonetos, resultando em uma queima mais curıpleta, com indices de emissões muito inferior aos motores similares a gasolina;

- A queima mais completa do gás natural reduz por conseguinte, a formação de resíduos de carbono na câmara de combustão, prolongando a vida útil do motor;

- O maior poder anti-detonante do gás natural (metano), permite o seu uso com taxas de compressão maiores, contribuindo para um maior rendimento térmico do motor;

- Nas condições normais de temperatura e pressão, ele existe na forma de gás, e nesta condição, se mistura facilmente com o ar atmosférico em qualquer proporção. Ao contrário dos combustiveis líquidos, não há necessidade de vaporizá-lo para entrar em combustão. As partidas a frio do motor a gás são mais fáceis, não havendo necessidade de enriquecer a mistura. Nos motores alimentados com gasolina, o 
enriquecimento da mistura durante as partidas a frio, constitui-se na maior fonte de emissão de monóxido de carbono (CO).

- Os Limites de inflamabilidade da mistura (ar-gás natural) que proporciona condições de autoinflamação é estreito da ordem de 5 a $15 \%$. em volume.

- A temperatura de auto-ignição do gás natural é cerca de $650^{\circ} \mathrm{C}$, bem superior a gasolina que se inflama aproximadamente a $300^{\circ} \mathrm{C}$.

- A densidade do gás natural é inferior a do ar atmosférico, de modo que em caso de vazamento, o gás sobe e se dispersa rapidamente. Além disso, como medida de segurança o gás natural é odorizado de forma que uma concentração da ordem de $0,5 \%$ de gás no ar é detectada. Tal concentração, não é prejudicial a saúde e é muito menor do que o limite inferior de inflamabilidade da mistura ar-gás natural;

- O gás metano não é tóxico quando aspirado em baixas concentrações, entretanto, a inalação deste gás a altas concentrações pode causar vômitos e asfixia.

\section{4 - ARMAZENAMENTO E ABASTECIMENTO}

Segundo BRUNETTI (1996), a densidade energética do metano é aproximadamente $40 \mathrm{MJ} / \mathrm{Nm}^{3}$, o que corresponde aproximadamente ao mesmo conteúdo energético de 1 litro de gasolina não etanolizada. Em outras palavras, isto significa que, em igualdade de condições, a autonomia do veículo a gás metano seria 1000 vezes menor que o mesmo, alimentado com um tanque de gasolina de igual 
capacidade. Isto impõe a necessidade de utilização de formas especiais de armazenamento para uso de combustíveis gasosos em veículos.

O gás natural pode ser armazenado no compartimento do veículo na forma de gás comprimido em tanques de alta pressão, como gás liquefeito à temperaturas criogênicas ainda através da tecnologia de hidretos metálicos (adsorção molecular). As duas últimas formas de armazenamento de gás, encontram-se em fase de desenvolvimento e ainda são muito dispendiosas, com raras aplicações práticas na engenharia automotiva. BEVIER et al (1989) e WEAVER (1989)

De acordo com WEAVER (1989), o armazenamento de gás natural na forma comprimida para utilização em motores automotivos, é menos onerosa e mais uriluzada. E!e destace que, à pressão máxima, recomendada por norma, de armazenamento do gás natural nos cilindros dos veículos é de 220 bar. Nesta pressão, o GNC ocupa um volume de cinco vezes o volume do combustível diesel e quatro vezes o volume da gasolina com o mesmo conteúdo energético. $O$ peso e o tamanho dos cilindros de armazenamento tem sido constantemente citados com desvantagens para o uso de GNC em motores automotivos, principalmente em carros de passeio

ESTON (1992) destaca que os cilindros de aço para gás natural fabricados no Brasil apresentam peso de $1,4 \mathrm{Kg}$ por litro hidráulico, enquanto na Itália os cilindros são $30 \%$ mais leves, de $1,0 \mathrm{Kg}$ por litro hidráulico. Existem ainda os cilindros chamados "compósitos" de alumínio, reforçados com fibra de vidro ou de alumínio com relação de peso volume de $0,5 \mathrm{Kg} /$ litro, o que corresponde a uma redução de quase $2 / 3$ em relação aos cilindros de aço. 
ESTON (1992) descreve ainda que a tecnologia de armazenamento de gás natural por adsorção molecular vem sendo desenvolvida nos Estados Unidos e Inglaterra, sendo que naquela época já se conseguia armazenar a 25 atmosferas com zeólitos, a mesma massa de gás comprimido correspondente a 100 atmosferas. Segundo ele, alguns obstáculos precisam ainda ser vencidos, tais como liberação de calor no enchimento por frações mais pesadas do gás, vida útil etc.

Segundo WEAVER \& TURNER (1994) estudos mais recentes, mostram que o emprego de compósitos podem reduzir o peso dos cilindros até $70 \%$ em relação aos cilindros de aço e 30 a 50\% em relação aos tanques de alumínio.

Existe basicamente duas modalidades de enchimento dos cilindros de gás natural, o enchimento lents, e ₹ enchimenta rópids. NI snchimento lento tem-se a compressão gradual do gás, fluindo de unı compressor para o cilindro a ser abastecido. No início do enchimento, o gás no cilindro sofre um processo de expansão com o conseqüente abaixamento de temperatura. Depois a temperatura do gás sobe acima do ambiente, em virtude do atrito das moléculas do gás com as paredes do cilindro. WEAVER (1989), PETROBRÁS (1988-a) e PETROBRÁS (1988-b)

No enchimento rápido, o gás flui, sob alta pressão, de um banco de cilindros "tanque-pulmão" para o cilindro vazio. No início, a temperatura do gás no cilindro cai drasticamente e depois cresce até 10 a $20^{\circ} \mathrm{C}$ acima da temperatura ambiente. $\mathrm{O}$ fator de compressibilidade $(Z)$, diminui com o aumento da pressão e temperatura do gás no cilindro. MAXWELL (1995) e WEAVER (1989) 
A Figura 2.4, publicada por MAXWELL (1995), apresenta esquematicamente um posto de abastecimento típico de gás natural comprimido.

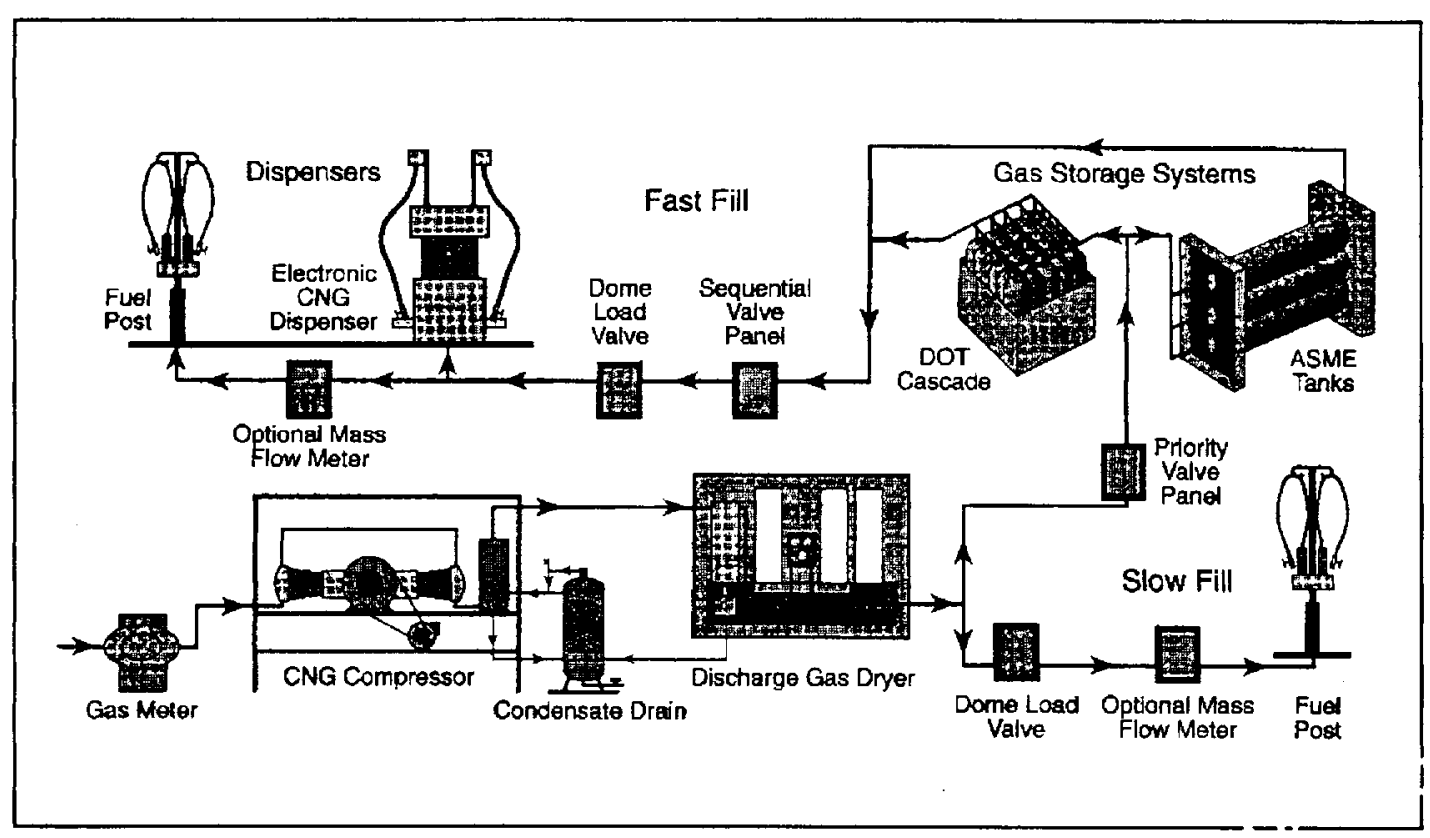

FIGURA 2.4 - Diagrama Esquemático de um Posto de Abastecimento de Veículos com GNC.

\section{5 - SISTEMAS DE FORMAÇÃO DE MISTURA}

Nos motores de ignição por centelha o processo de formação da mistura arcombustivel pode ter inicio no coletor de admissão ou no interior do cilindro. A formação da mistura no coletor de admissão é a maneira mais simples de alimentação desses motores, sendo normalmente conseguida por meio de um carburador ou ainda através de sistemas de injeção de combustível a baixas pressões. A injeção no coletor 
de admissão, pode ser realizada com um único injetor ("single-point") ou por vários injetores, normalmente um por cilindro ("mult-point"). BOSCH (1989) e BOSCH (1993)

Por outro lado, a formação da mistura no interior do motor, imperiosamente, é realizada por sistemas de injeção que pode ser de baixa ou alta pressão. Nos sistemas de injeção direta a baixas pressões (cerca de 10 a 15 bar), a injeção de combustível pode ocorrer durante os cursos de admissão e ou parte da compressão, logo após o fechamento da válvula de admissão. SILVA (1993)

A injeção direta de combustível em motores de ignição por centelha, ao contrário do motor diesel, não tem como função inflamar ou regular o periodo de

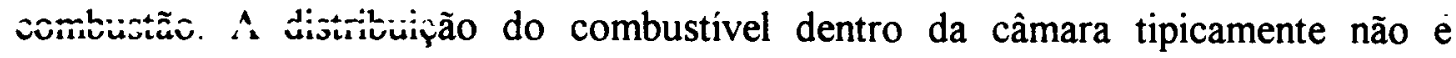
uniforme, apresentando zonas de razão ar-combustível variáveis. Tal mistura é denominada de carga estratificada. BRUNETTI (1996), BOSCH (1994), BOSCH (1993)

Nos motores a gás, a injeção direta a baixas pressões na compressão, permite a aspiração somente de ar atmosférico durante o curso de admissão e por conseguinte elimina por completo a perda de potência ocasionada pela baixa densidade do gás quando inserido no curso de admissão. Esta técnica apresenta como vantagens a maior utilização da carga de combustível disponível nos cilindros de gás e a eliminação do retorno de chama, fenômeno tão característico nos motores carburados ou de injeção indireta. Por outro lado, a injeção direta, em motores de ignição por centelha, realizada a altas pressões no final do curso de compressão, consiste num método muito eficaz no combate a pré-ignição, sendo recomendada para combustiveis 
com altas velocidades de chama e grandes limites de inflamabilidade, como é o caso do hidrogênio. SILVA (1993)

\section{6 - MOTORES DE CARGA ESTRATIFICADA}

A história da injeção direta de combustíveis em motores do ciclo Otto é tão antiga quanto o próprio motor de ignição por centelha. Dados históricos revelam que em 1884, um motor "Spiele" funcionou com injeção direta no cilindro de combustível leve. Com o desenvolvimento mais tarde do carburador, este método de injeção de combustível foi abandoriadú, ressurgindn temnns dẹ yis com o finalidade de prevenir a detonação. KOWALEWICZ (1984)

Nos primeiros motores do ciclo Otto com injeção, o combustível era injetado diretamente na câmara de combustão durante o curso de admissão, com pressões de injeção da ordem de 100 a 500 bar. LENZ (1992)

Segundo KOWALEWICZ (1984), a injeção direta de combustiveis em motores de ignição por centelha, foi muito utilizada em aviões e tanques de guerra durante a II guerra mundial, em virtude das altas pressões médias efetivas e altas velocidades do motor que este método de injeção proporcionava.

A estratificação da carga possibilita estender o limite inferior de inflamabilidade das misturas ar-combustível, melhorando as propriedades 
termodinâmicas do fluído de trabalho, de modo que a operação com excesso de ar permite obter maior economia de combustível. FRENC (1980) e REYMOND (1980)

Até hoje (1984), a injeção direta é utilizada em motores de avião, carros de corrida e carros de passeio, em conseqüência das seguintes características: KOWALEWICZ (1984)

- maior economia, principalmente em cargas parciais;

- menor indice de emissões;

- possibilidade de queimar combustíveis de baixa octanagem;

SPRINGER (1996) descreve que a injeção direta de motores a gasolina tem sido exaustivamente pesquisada no Japão nos últimos anos pela Mitsubishi e pela Toyota. Segundo ele, o motor da Toyota de ignição por centelha e carga estratificada pode operar com razões ar-combustível de até 50: 1, resultando em uma economia de combustível de até $30 \%$ em relação aos similares com mistura pré-misturadas.

SHIMOTANI et al (1996) investigaram as características de um motor a gasolina com injeção direta de gás natural. Segundo eles, o motor de carga estratificada pode operar com misturas estequiométricas ou misturas pobres. Cargas demasiadamente estratificadas aumentam o consumo de combustível com maiores emissões de hidrocarbonetos não queimados, uma vez que, misturas muito ricas localizadas causam combustão incompleta.

DAISHO (1990) investigou o desempenho de um motor de dois tempos operando com injeção direta de gasolina. Os resultados mostram uma melhor 
eficiência térmica e menores emissões de NOX do motor operando com injeção direta em relação a injeção original de gasolina no coletor.

A Toyota do Japão, anunciou recentemente, o lançamento de um novo produto no mercado. Trata-se de um motor D-4 de carga estratificada com injeção direta de gasolina. Neste motor há 4 válvulas por cilindro, com sistema de recirculação de gases da combustão (EGR) e a injeção de gasolina é feita a uma pressão $12 \mathrm{MPa}$. A estratificação da carga é proporcionada pela alta pressão de injeção, pelo formado da câmara de combustão e disposição das válvulas, especialmente projetadas com esta finalidade. $O$ injetor é especialmente tratado para evitar acúmulo de depósitos. Comparado com os motores convencionais, apresenta uma economia de combustível da ordem de $30 \%$ e redução nas emissões da ordem de $95 \%$. TOYOTA (1996)

STONE (1993), ressalta que a injeção direta de combustíveis líquidos nos cilindros do motor de ignição por centelha seguramente ocasiona estratificação de carga, uma vez que a mistura ar-combustível dispõe de menos tempo para homogeneização. Por outro lado, os injetores de combustível para injeção direta devem ser capazes de resistir às altas temperaturas e pressões da câmara de combustão.

OBERT (1971), descreve que no motor Otto de carga estratificada, a mistura é inflamada pela vela de ignição e a frente de chama deve-se deslocar a todas as misturas de combustíveis. A mistura é mais resistente à detonação, pois o gás final não necessariamente é uma mistura inflamável e também o tempo de permanência ou 
aquecimento do combustível é menor, uma vez que a injeção começa mais tarde no curso de compressão.

A Figura 2.5, extraída do KOWALEWICZ (1984), apresenta o motor Helsselman de carga estratificada.

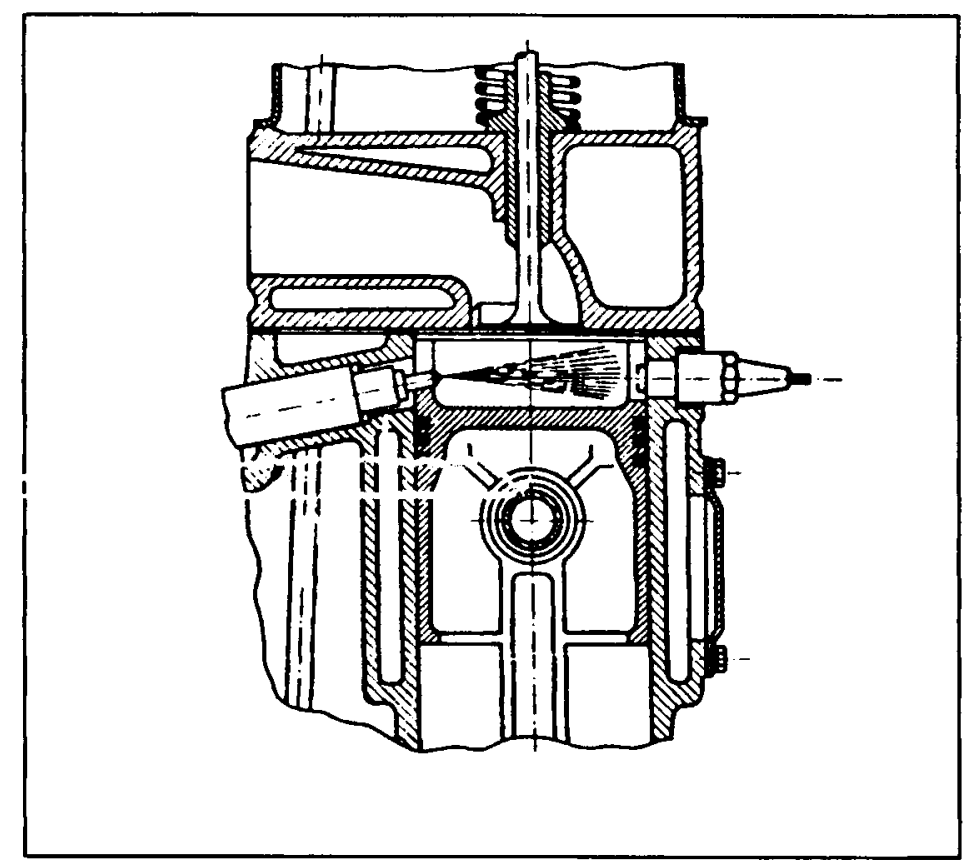

FIGURA 2.5 - Sistema de Combustão Hesselman.

Segundo KOWALEWICZ (1984), o combustivel era injetado no final do curso de compressão dentro da câmara de combustão, sendo inflamado logo depois por uma centelha colocada do lado oposto do injetor. A frente de chama consumia inicialmente as misturas levemente rica nas vizinhanças da vela e depois se propagavam com grandes velocidades consumindo as misturas mais pobres. A alta 
turbulência gerada pela geometria da câmara de combustão e válvulas permitiam a estratificação da carga admitida no cilindro.

De acordo com REYWOOD (1988), desde a década de 20, inúmeras tentativas tem sido feitas no sentido de desenvolver um motor de combustão híbrido que combine as melhores vantagens dos motores de ignição por centelha e dos motores diesel. A finalidade é desenvolver um motor com taxas de compressão consideradas ótimas para o desempenho de um motor ciclo Otto (na faixa de 12 a 15). Para tanto, o motor deve apresentar as seguintes características:

1) Injeção do combustivel diretamente dentro da câmara de combustão, durante o processo de compressão (para evitar o problema da detonação ou ignição expontânea,

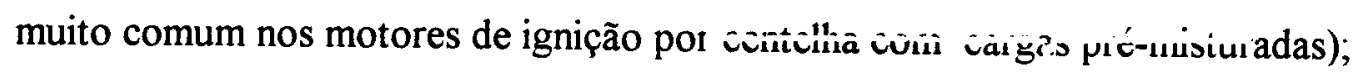

2) Inflamação do combustível com uma vela de ignição na medida que ele se combina com o ar para obter controle direto do processo de ignição.

3) Controle do nível de potência variando-se a quantidade de combustivel injetada por ciclo (com a vazão de ar não estrangulada para minimizar o trabalho de bombeamento).

Diferentes tipos de motores de carga estratificada tem sido propostos ao longo dos anos, mas somente poucos tem sido completamente desenvolvidos e utilizados em motores veiculares. A Figura 2.6, reproduzida do REYWOOD (1988), apresenta dois modelos de motores de carga estratificada utilizados comercialmente. 
A câmara de combustão desses motores apresenta um formato côncavo, proporcionando um alto grau de redemoinhos "swirl" ao ar aspirado, fundamental para uma combustão rápida da mistura ar-combustível.

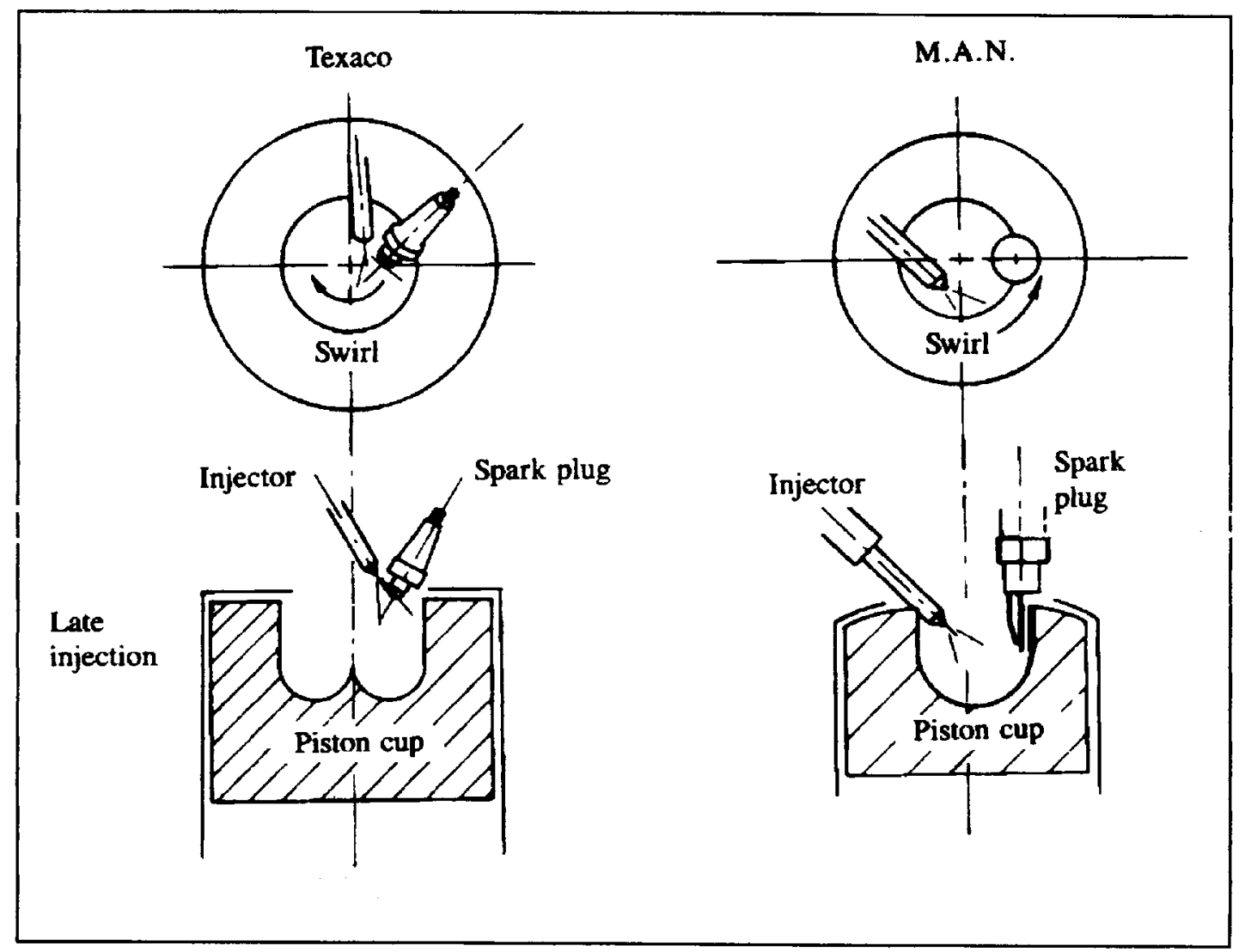

FIGURA 2.6 - Motores de Carga Estratificada de Produção Comercial: O Sistema de Combustão Controlada TCCS da TEXACO e o Sistema FM da MAN.

O combustível é injetado tangencialmente e direcionado para a concavidade do pistão, durante os últimos estágios da compressão. Uma descarga elétrica de longa duração inflama o jato em desenvolvimento nas vizinhanças da vela de ignição. A partir daí, frente de chama se expande consumindo a mistura ar-combustivel até os estágios finais da combustão que são completados durante o curso de expansão. Estes 
motores são usualmente denominados de motor de carga estratificada com injeção direta.

Um outro conceito de motor carga estratificada, proposto em 1918 por Ricardo, tem sido extensivamente desenvolvido e produzido na Ex-União Soviética e no Japão. Este motor também é freqüentemente denominado de motor de ignição por jato "jet-ignition" ou de ignição por tocha "toch-ignition". A Figura 2.7, reproduzida do REYWOOD (1988), apresenta uma versão deste motor com três válvulas.

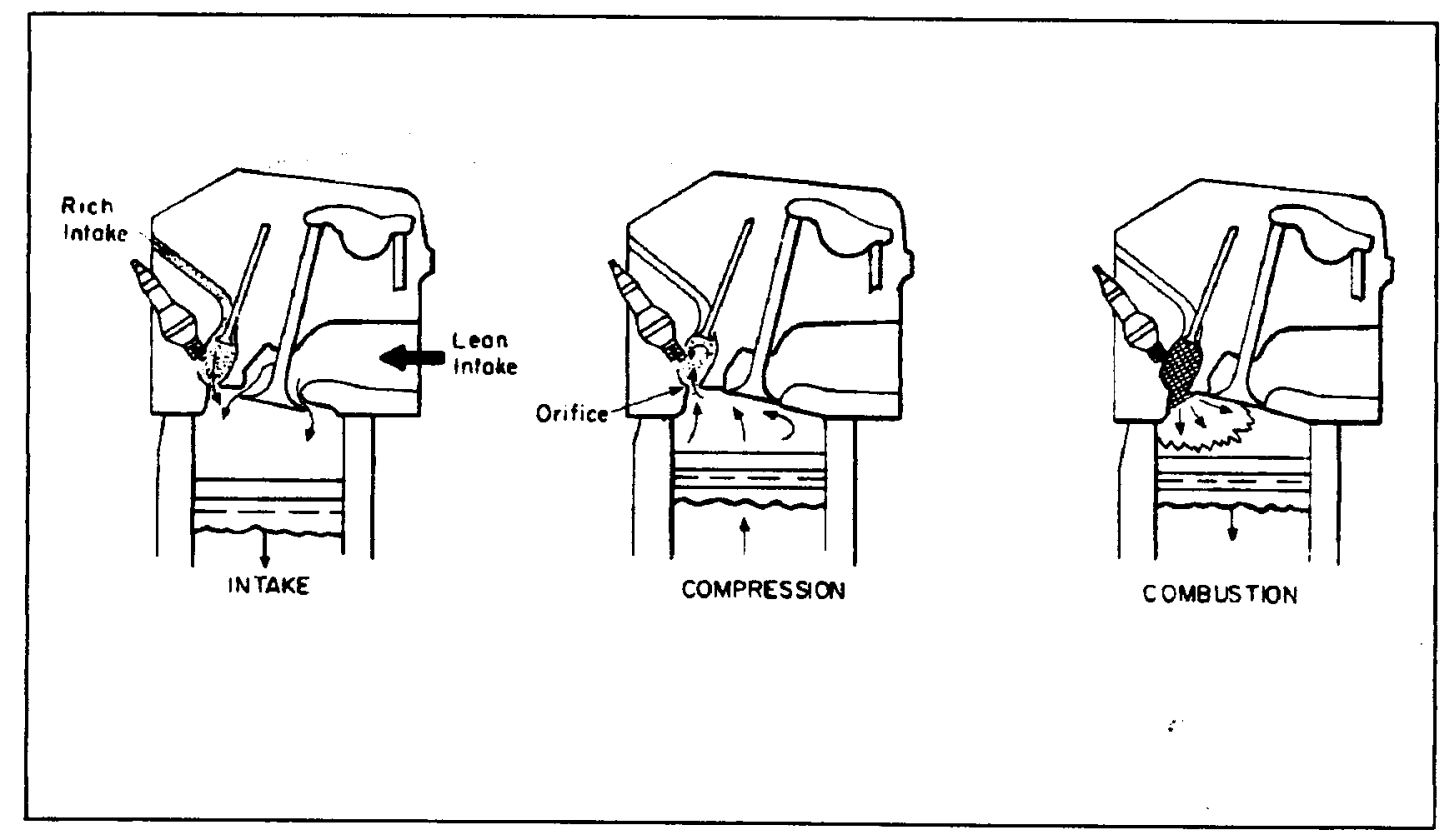

FIGURA 2.7 - Esquema de um Motor Ciclo Otto de Carga Estratificada e Ignição por Tocha.

O volume de uma pequena pré-câmara, aonde está inserida a vela de ignição, é preenchido completamente com uma mistura muito rica em combustivel (que contém 
combustível além da quantidade que pode ser inflamada com o ar disponível), através de uma válvula auxiliar.

Ao mesmo tempo, a mistura principal muito pobre (que contém ar além daquele requerido para queimar completamente o combustivel) é introduzida na câmara principal do motor através da válvula de admissão e preparada de forma convencional por um sistema de carburação ou injeção indireta.

Após o fechamento da válvula de admissão, as pressões no cilindro crescem e a mistura pobre é comprimida para dentro da pré-câmara tornando a mistura nas vizinhanças da vela de ignição facilmente inflamável e levemente rica. Depois que esta mistura levemente rica é inflamada na pré-câmara, um jato de mistura em combustão

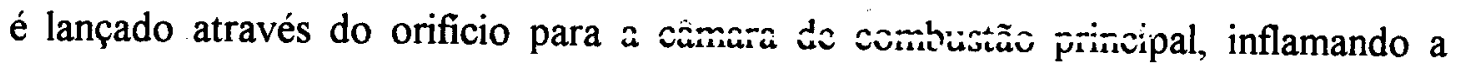
carga principal de mistura pobre ali existente.

A finalidade da pré-câmara é transformar a frente de chama iniciada ao redor da vela de ignição em um ou mais jatos de chama na câmara de combustão principal, os quais apresentam uma maior superficie de área, com maior capacidade de diluição e maior poder de inflamação de misturas pobre.

Muito embora denominado de motor de carga estratificada, ele é realmente um motor de ignição por jato, cuja função básica é ampliar o limite de operação dos motores de ignição por centelha convencional para misturas mais pobres. REYWOOD (1988) e KOWALEWICZ (1984) 


\section{7 - CONVERSÃo DE MOTORES PARA GÁS NATURAL}

TENNANT (1994) e WEAVER (1989), relatam que a conversão de motores convencionais para operação com combustíveis gasosos, particularmente, gás natural e GLP já existe à décadas, e consiste numa prática bastante comum nos países que não dispõe de grandes reservas de petróleo como é o caso da Itália, Nova Zelândia e Japão. Em 1981, operavam com GLP 550.000 veículos na Itália, 380.000 na nova Zelândia, 60.000 na Bélgica, 35.000 na Dinamarca e 23.000 na Alemanha. LENZ (1992). Ultimamente, nos Estados Unidos e Canadá, para atender à legislação ambiental, muitos veículos de frota foram convertidos para operar com gás natural ou

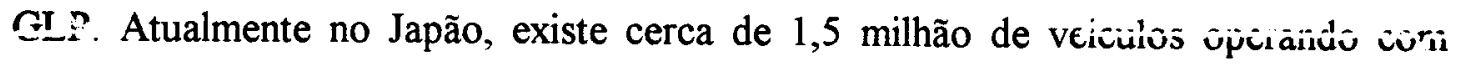
GLP. MAXWELL (1995)

De acordo com BOSCH (1993), LASTRES (1987) e RODAGÁS (1984), o gás metano principal constituinte do gás natural e também do biogás, pode ser empregado tanto para acionar motores do ciclo Diesel quanto do ciclo Otto. Entretanto, a alimentação do combustível e o processo de combustão da mistura arcombustível ocorre de forma diferente em cada ciclo. A conversão de um motor de ignição por centelha convencional a gasolina ou a álcool para operação com gás metano, pode ser realizada segundo diferentes graus de complexidade, no que tange ao sistema de alimentação e à otimização do processo de combustão.

A conversão mais simples consiste na adaptação de um motor ciclo Otto para operação no modo bi-combustivel e é realizada mediante a incorporação de um 
sistema de alimentação de gás ao motor, preservando suas características construtivas originais. A falta de regularidade no abastecimento de gás, justifica este tipo de conversão, uma vez que o modo bi-combustivel não retira a habilidade do motor de operar com o combustivel original. SILVA (1993), WEAVER (1989) e LASTRES (1987)

De acordo com MAXWELL (1995), nos motores convertidos ou projetados para uso exclusivo do gás natural, o rendimento térmico é aumentado pela adoção de taxas de compressão adequadas ao gás e adicionalmente otimizando-se a curva de avanço da centelha. Um aumento significativo de rendimento volumétricc somente é possível por meio de supercarregamento do motor, alteração no diagrama ou número de válvulas ou ainda fạendo a injeção do combustível gasoso diretamente do cilindro do motor.

Os sistemas de conversão de veículos para uso do GNC ou GLP comercializados atualmente são basicamente dois: os sistemas mecânicos (carburação) e os sistemas de injeção eletrônica. Os sistemas mecânicos tem sido usados por muitos anos e operam de forma semelhante aos sistemas de carburação à gasolina. Os sistemas eletrônicos utilizam injetores ou válvulas de controle de fluxo para dosar o combustível na corrente de ar. MAXWELL (1995) e BOSCH (1993)

A Figura 2.8, publicada por MAXWELL (1995), mostra o esquema típico de um sistema mecânico de conversão de um motor convencional a gasolina para operação com gás natural ou GLP. O sistema mecânico de conversão para uso do GNC ou GLP são muito semelhantes, exceto quanto aos cilindros de armazenamento de gás, vaporizadores e o regulador de pressão. 
O sistema de conversão mecânico a gás, consiste basicamente de um misturador, válvulas de bloqueio de combustivel, filtros de combustível, regulador de pressão e reservatórios de armazenamento de gás.

Opcionalmente, pode ser incorporado ao sistema mecânico um pacote eletrônico "kit" que possibilita dentre outras funções de controle, a operação com sensor lâmbda $(\lambda)$ em circuito fechado "closed-loop". O sistema mecânico com o kit eletrônico opcional corresponde a um carburador eletrônico de gás.

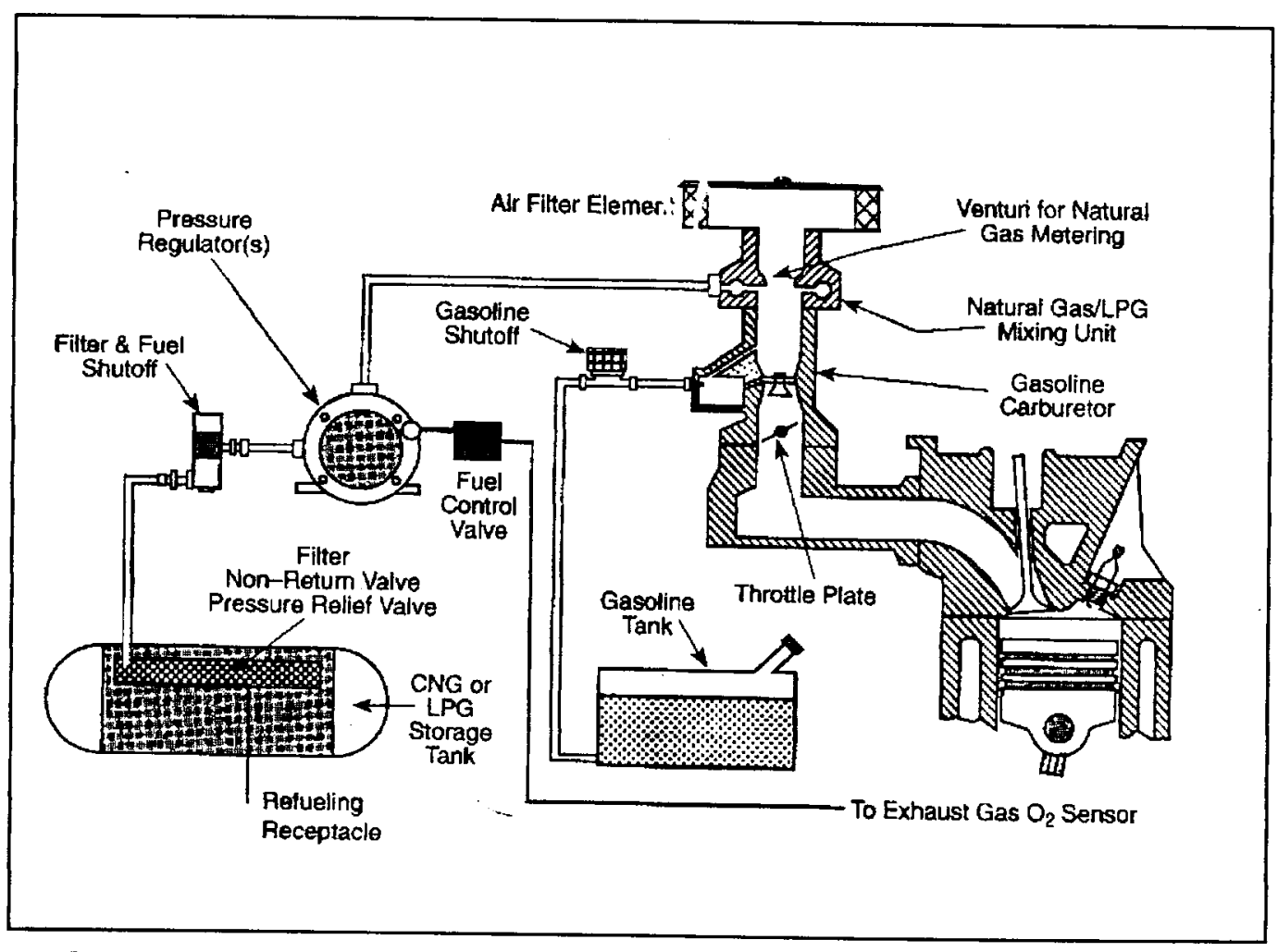

FIGURA 2.8 - Diagrama Típico de um Sistema Mecâniço de Conversão Bicombustivel para uso do GNC ou GLP. 
A Figura 2.9, também extraída do MAXWELL (1995), apresenta um sistema típico de conversão de um motor convencional a gasolina para operação com injeção eletrônica de gás Natural ou GLP. Na injeção eletrônica de gás natural o combustivel é injetado no coletor de admissão de modo semelhante à injeção de combustíveis liquidos (gasolina ou álcool).

Fazem parte também do sistema de injeção eletrônica de gás, um regulador de pressão que reduz a pressão de armazenamento do gás para a pressão de alimentação do injetor, válvulas de bloqueio de gás, filtros e reservatórios de armazenamento de gás.

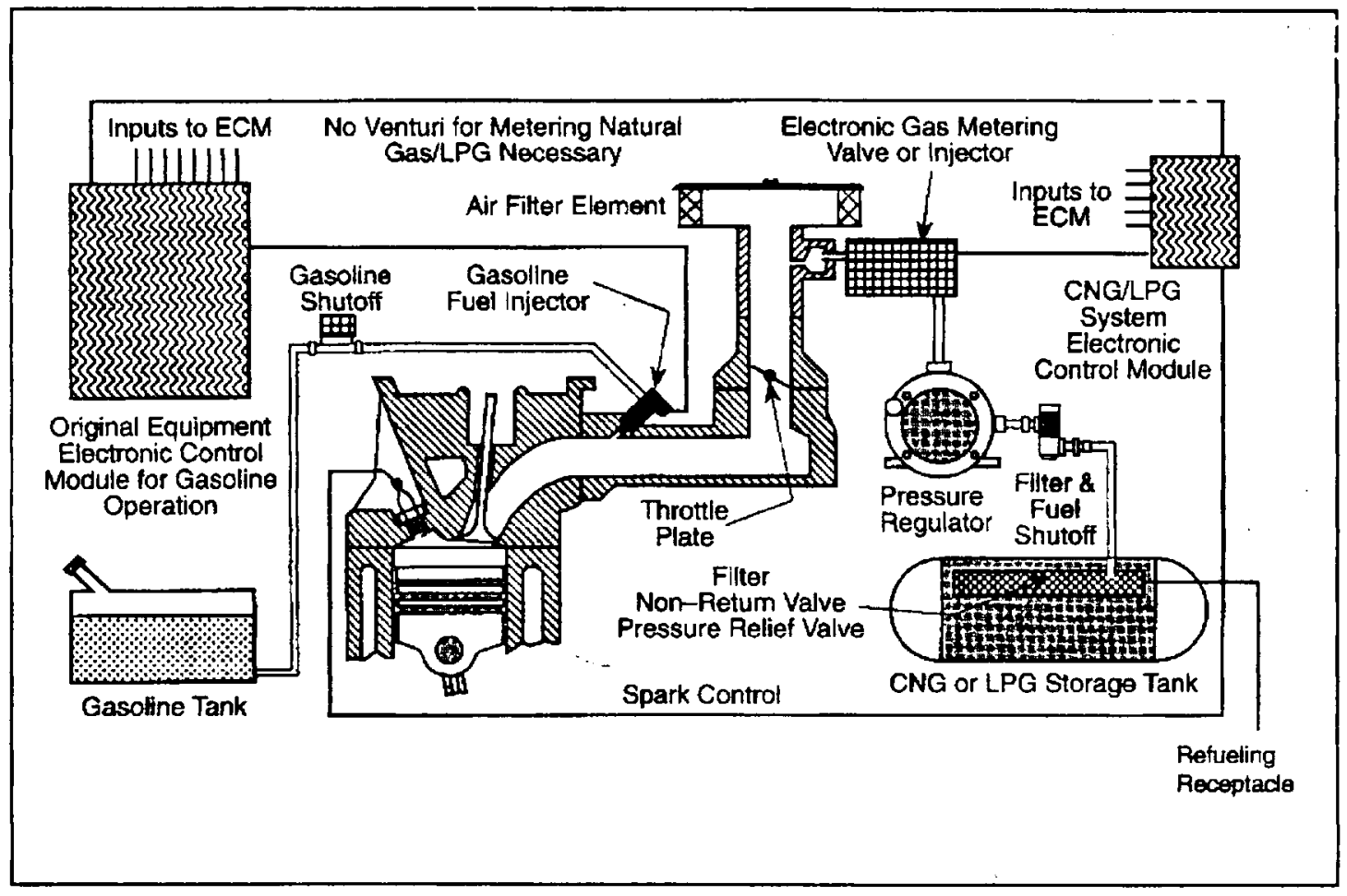

FIGURA 2.9 - Diagrama Típico de um Sistema de Conversão Eletrônico Bicombustível para uso do GNC ou GLP. 


\section{8 - DESEMPENHO DOS MOTORES A GÁS NATURAL}

KO et al (1991) investigaram o desempenho de um motor monocilindrico com injeção direta de gás natural a altas pressões $(8 \mathrm{MPa})$. Os resultados mostram um aumento significativo de eficiência térmica do motor em altas cargas.

MAXWELL (1995) descreve que a perda total de potência nos motores bicombustível, convertidos para uso do gás natural pode ser de até $30 \%$, dos quais aproximadamente $10 \%$ é devido a baixa densidade do combustível gasoso e o iesianté, cerca de $20 \%$. node ser atribuído ao "kit" de carburação a gás. Segundo ele, muitos motores convertidos para queimar gás natural ou GLP, apresentam uma perda de potências que varia entre 10 e $20 \%$, devido à restrição imposta pelo "Kit" de carburação de gás.

Para MAXWELL (1995), a perda de eficiência volumétrica dos motores a gás pode ser compensada aumentando-se a pressão de admissão por intermédio de superalimentadores ou turboalimentadores. Uma outra possibilidade que tem sido considerada é enriquecer o conteúdo de oxigênio do ar empregando uma membrana separadora de gás ou outro mecanismo. $O$ enriquecimento de oxigênio, no presente momento, é alvo de algumas pesquisas, não sendo encontrado em veículos comerciais. 
MAXWELL (1995) afirma ainda que a perda de potência devido a queda de eficiência volumétrica dos motores a gás (gás natural e GLP) pode ser eliminada totalmente fazendo-se a injeção do combustivel diretamente no cilindro do motor. Entretanto, esta técnica de injeção direta de gás natural ou GLP ainda não se encontra disponível no mercado.

TENNANT (1994) e WEAVER (1989) descrevem que a queda de potência nos motores a gasolina adaptados para operação no modo bi-combustivel com GNC tem sido exaustivamente documentada, variando no intervalo de 11,3 a $22 \%$. Segundo estes pesquisadores, as principais razões desta queda de potência são a perda de eficiência volumétrica, devido ao volume deslocado pelo GNC e, por outro lado, o acréscimo de eficiência volumétriçe, deviido ao aumento de densidade da carga aspirada, promovido pela evaporação do combustivel líquido (gasolina) no coletor de admissão.

Testes realizados na universidade de Toronto com um motor 4.9 litros I-6, apresentou uma queda de potência entre 12 e $22 \%$ e entre 6 a $15 \%$ com um motor V8 de 6.1 litros, quando convertidos de gasolina para funcionar com GNC. Segundo os pesquisadores, Para compensar a baixa densidade energética da mistura ar-GNC e desenvolver a mesma potência do motor a gasolina de $350 \mathrm{in}^{3}$, foi necessário aumentar a cilindrada do motor em $83 \mathrm{in}^{3}$. Na conversão do motor, foi utilizado um sistema single-point para injeção de GNC e ignição mapeada. CHIU et al (1991)

HARA (1994) investigou o desempenho de um motor de ignição por centelha monocilíndrico com taxa de compressão variável, de quatro tempos, funcionando com GNC ou gasolina, variando o fator de excesso de ar, o tempo de ignição por centelha, 
a razão de compressão. Também investigou os efeitos da adição de oxigênio durante a operação do motor com GNC. O motor pode operar com altas razão de compressão de até 19:1, com misturas pobre de GNC $\operatorname{com} \lambda=1,6$. A potência do motor foi maximizada e o limite inferior de inflamabilidade, isto é o limite de combustão pobre ampliado, adicionando-se pequenas quantidades de gás oxigènio ao ar de admissão. Na razão de compressão 19:1, a potência do motor com GNC aumentou $92 \%$ em comparação com a potência desenvolvida pelo mesmo motor funcionando com gasolina com taxa de compressão de 9:1.

SPRINGER et al (1994) realizaram testes de emissões em dinamômetro de chassi com uma Pick-up Chevrolet de $3 / 4$ ton. e constataram que na partida a frio do motor usando GNC se reduz em até $70 \%$ as emissñes de pcliuculies cm teiação a operação com gasolina.

GOTO \& NARUSAWA (1996) investigaram a influência de diversos parâmetros sobre a estabilização da combustão, e em particular das misturas pobres "lean burn" em um motor de ignição por centelha. Segundo estes pesquisadores, o aumento da turbulência na mistura de GNC-ar, contribui para uma frente de chama mais estável e com menores variações cíclicas. A formação de óxidos de nitrogênio (NOx) é fortemente influenciada pelo fator de excesso de ar $(\lambda)$, sendo reduzida drasticamente quando se utiliza misturas pobres, as quais proporcionalmente apresentam menores temperaturas indicada.

ISHII et al (1994) investigaram algumas características de desempenho e emissões de um motor com injeção MPI a gasolina de 6 cilindros, com taxa de compressão de 9:1 e convertido para operação no modo bi-combustível com injeção 
MPI de GNC. Os resultados indicam que a máxima potência do motor com injeção de GNC foi $15 \%$ menor em relação ao motor com injeção de gasolina usando a mesma taxa de compressão. Os gráficos da Figura 2.10 mostram o desempenho do motor com injeção MPI de gasolina ou GNC, para o regime de plena carga.

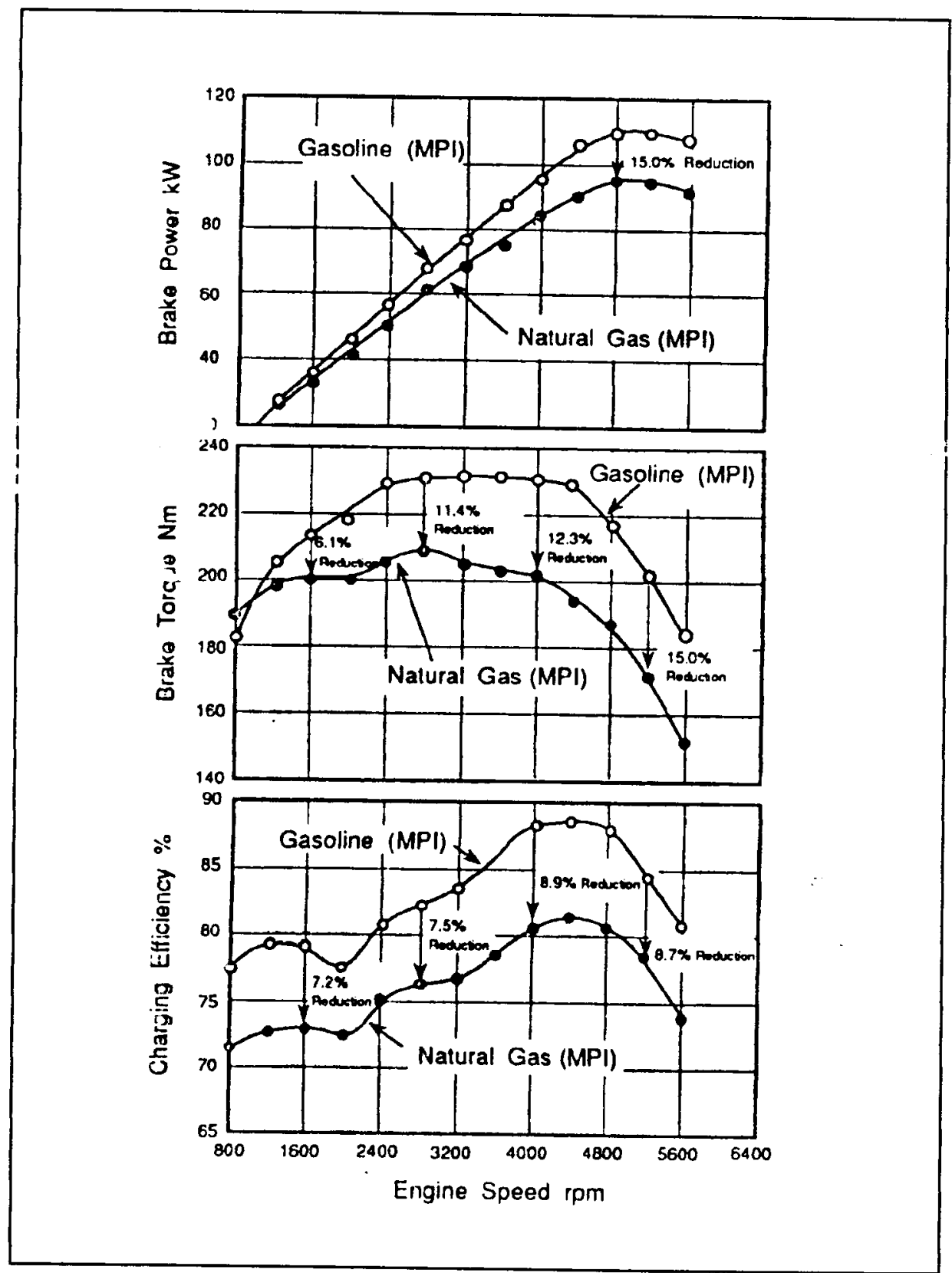

FIGURA 2.10 - Curvas de Desempenho de Motor Operando com Gasolina e GNC em Regime de Plena Carga. 


\section{CAPÍTULO 03 - SISTEMAS DE INJEÇÃo ELETRÔNICA DE COMBUSTÍVEL PARA MOTORES DE IGNIÇÃo POR CENTELHA.}

\section{1 - SISTEMAS DE CONTROLE INTEGRADOS}

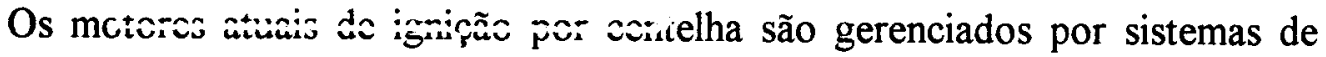
controle integrados os quais incorporam as funções de controle da injeção de combustível, controle do avanço da centelha, controle do nível de detonação, controle da marcha lenta, controle das emissões de poluentes, controle da recirculação de gases de exaustão, controle das emissões evaporativas, dentre outros. Todos estes controles são gerenciados por uma unidade de-controle eletrônico (ECU). VOLKSWAGEN (1996-a), PROBST (1995), RIBBENS (1993) e LENZ (1992)

A Figura 3.1, publicada por MIZUTANI (1992), mostra um sistema típico de controle integrado de um motor de ignição por centelha. O coração do sistema é a unidade de controle eletrônico (ECU). A Figura 3.2, publicada pelo mesmo autor, apresenta o diagrama de bloco típico de uma ECU de um sistema de controle integrado. 


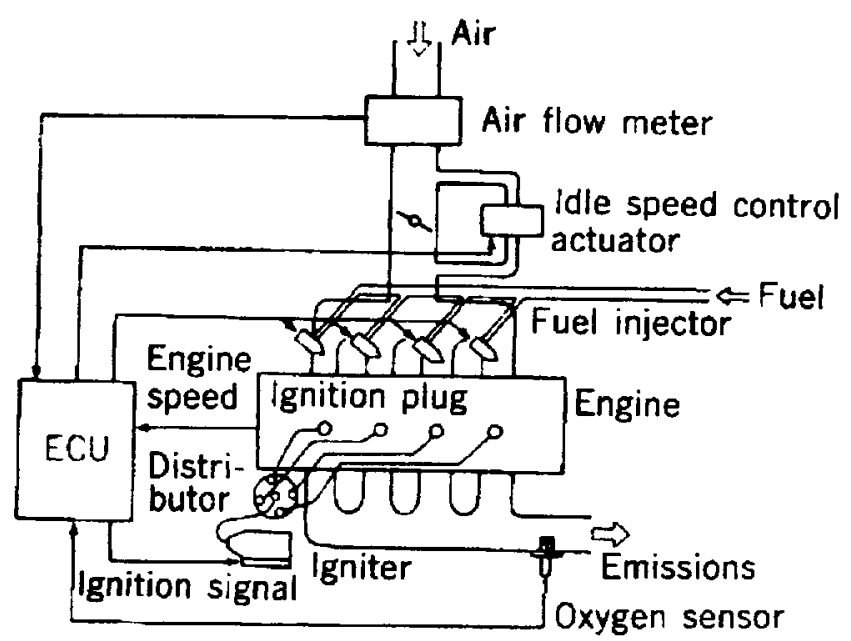

FIGURA 3.1 - Sistema de Controle Integrado Típico de um Motor.

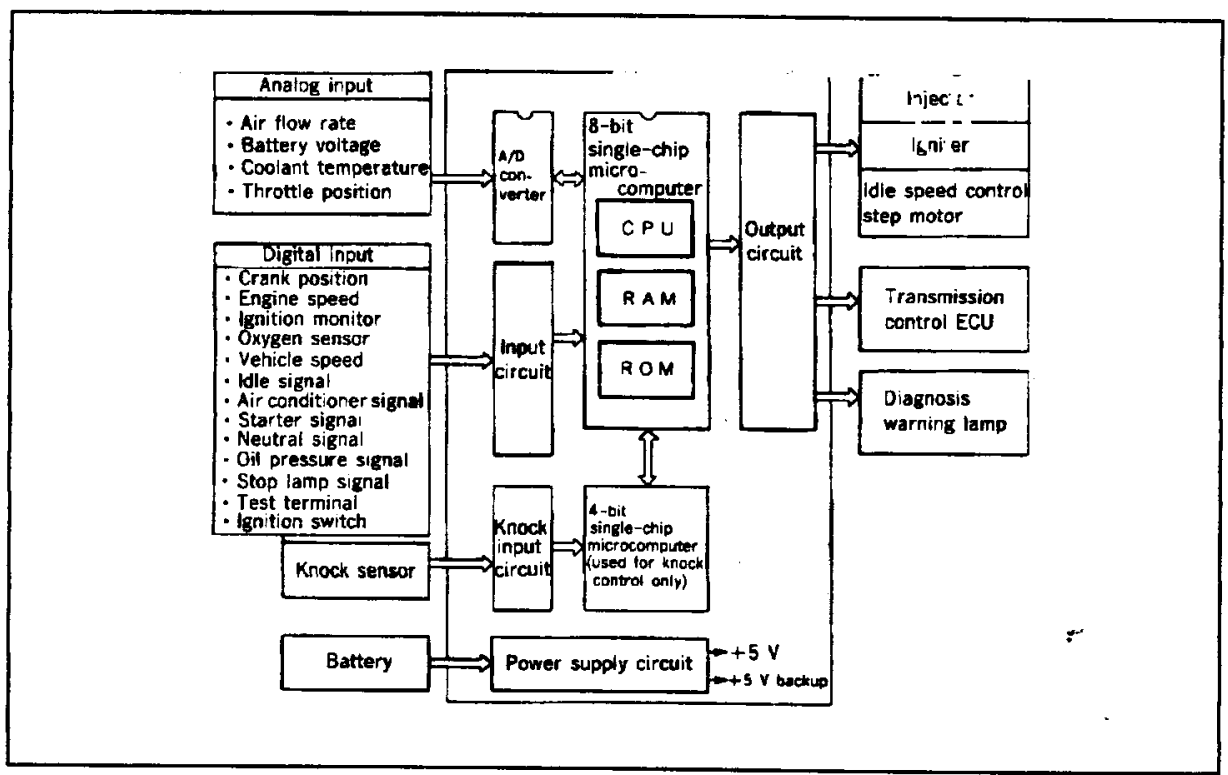

FIGURA 3.2 - Configuração de uma ECU.

De acordo com RIBBENS (1993), LENZ (1992) e MIZUTANI (1992), os sistemas de controle integrados possibilitam ao motor operar com um alto nível de desempenho, otimizando as curvas de potência e torque, reduzindo o consumo de combustivel e também as emissões de poluentes. 


\section{2 - INJEÇÃO ELETRÔNICA DE COMBUSTÍVEL}

Neste capitulo será abordado apenas o sistema de injeção eletrônica de combustivel, mas é importante ressaltar que o gerenciamento dos motores atuais é realizado de forma integrada, conforme elucidado no item anterior.

O princípio básico de funcionamento de um equipamento de injeção, para motores de ignição por centelha, consiste em regular a potência do motor controlando o fluxo de ar aspirado por meio de uma válvula restritora, geralmente uma borboleta, para posteriormente injetar o combustível, em algum ponto do coletor de admissão ou no interior do próprio cilindro, que satisfaçam aos requisitos de mistura para as diferentes condições de operação do motor. SENAI (1994-a), SENAI (1994-b) e MUÑOZ (1989).

Os sistemas de injeção eletrônica de combustível foram desenvolvidos com o objetivo de melhorar algumas característicos de desempenho do motor tais como potência, consumo específico de combustível, nível de emissões de poluentes e dirigibilidade. Uma variedade de sensores informam constantemente a ECU sobre as condições de operação do motor. Estas informações são usadas pela ECU para calcular a quantidade de combustível requerida pelo motor e controlar a injeção do combustível, nas diversas condições de operação. VOLKSWAGEN (1996-a), MOTOROLA (1993), RIBBENS (1993) e MIZUTANI (1992)

Os sistemas de injeção eletrônica de combustível, além de controlar a quantidade exata de combustivel em todas as condições de operação do motor, 
possuem ainda outras funções adicionais, tais como: corte de combustível durante as desacelerações, corte de combustível em velocidades excessivas, regulagem da razão ar-combustivel estequiométrica com sensor lambda, controle da recirculação dos gases de exaustão, controle das emissões evaporativas, diagnóstico de falhas e a operação em situações de emergência, dentre outras. PROBST (1995), BOSCH (1993), RIBBENS (1993) e MIZUTANI (1992)

O corte de combustivel durante as desacelerações abruptas tem como objetivo reduzir ao máximo o desperdício de combustível quando o motor funciona como freio motor, isto é, em altas velocidades e com a borboleta do acelerador totalmente fechada. Nestas condições, a ECU cessa o fornecimento de combustivel para o motor, sendo somente restabeleridn qu!ando a rotação do motor cai a um nível pré-calibrado.

A Figura 3.3, reproduzida do MIZUTANI (1992), ilustra o corte de fornecimento de combustível em situações de freio motor.

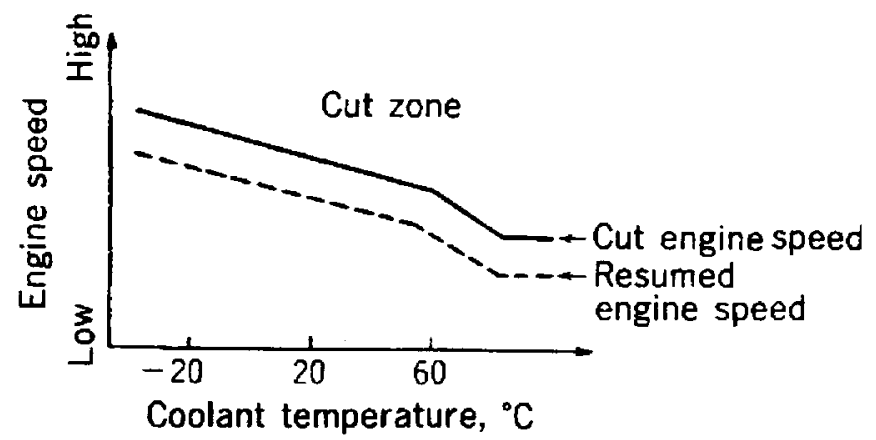

FIGURA 3.3 - Curva Típica de Corte de Combustível em Altas Rotações do Motor. 
Em casos de velocidades excessivas do motor, que podem danificar ou comprometer sua vida útil ou de alguns componente do motor, a ECU também reconhece esta condição e corta o fornecimento de combustivel para o motor, restabelecendo a injeção de combustivel somente quando as velocidades caem abaixo do limite de segurança. VOLKSWAGEN (1996-a), PROBST (1995), BOSCH (1993), RIBBENS (1993), MIZUTANI (1992) e BOSCH (1989)

A Figura 3.4, publicada por MIZUTANI (1992), mostra a taxa de conversão típica dos gases de exaustão em um catalisador de um motor de ignição por centelha, em função da variação do fator de excesso de ar $(\lambda)$.

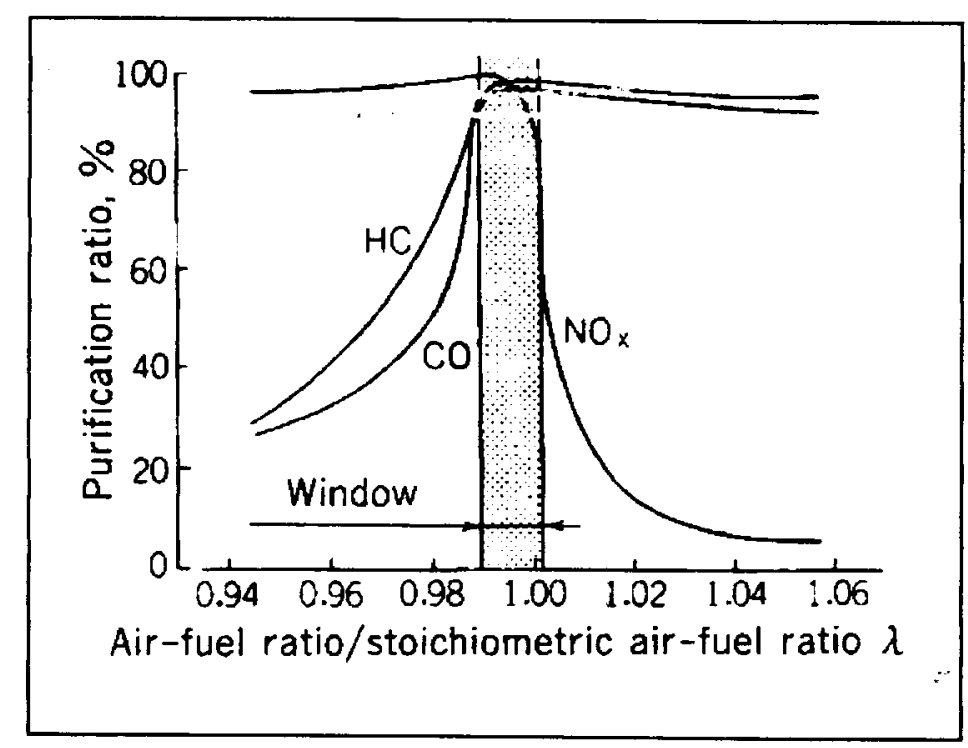

FIGURA 3.4 - Taxa de Purificação dos Gases de Exaustão Típica de um Catalisador de 3-Vias.

O conversor catalítico de 3 vias utilizado nos motores Otto, converte cerca de $90 \%$ dos gases poluentes da combustão ( $\mathrm{CO}, \mathrm{NOx}$ e $\mathrm{HC})$ em produtos inócuos como dióxido de carbono, nitrogênio, oxigênio e vapor d'água. Os hidrocarbonetos (HC) e o monóxido de carbono ( $\mathrm{CO}$ ) dos gases de exaustão, ao passar pelo catalisador, 
sofrem uma "reação de oxidação" promovida pelo Paládio $(\mathrm{Pb})$, transformando-se em vapor d'água $\left(\mathrm{H}_{2} \mathrm{O}\right)$ e dióxido de carbono (CO2). Por outro lado, os óxidos de nitrogênio (Nox) em contato com o molibdênio (Mo) ou Ródio (Rh) do catalisador, sofrem um "processo de redução" e são transformados em nitrogênio $\left(\mathrm{N}_{2}\right)$ e oxigênio (O2). PROBST (1995), BOSCH (1993), RIBBENS (1993) e LENZ (1992)

A Figura 3.4, mostra que para o bom funcionamento do conversor catalítico, é necessário que o motor funcione com razões ar-combustível muito próxima da razão estequiométrica. Manter a razão ar-combustível de um motor próxima da estequiométrica, somente é possível mediante o emprego de um circuito de controle de "laço fechado". PROSBT (1995), RIBBENS (1993), RODRIGUES (1993), VOLKSWAGEN (1991) e BOSCH (1989)

A Figura 3.5, publicada pela GLOECKLER (1984), mostra um motor cum conversor catalítico de três vias e circuito de laço fechado, retroalimentado com o sinal do sensor lambda.

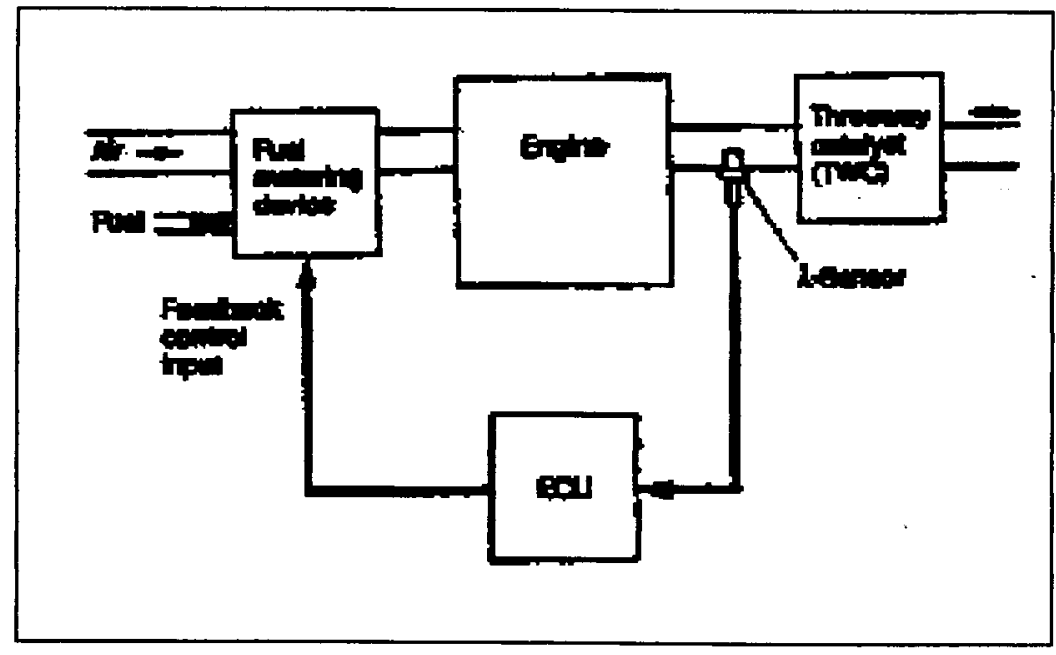

FIGURA 3.5 - Sistema de Retroalimentação com Sensor Lambda. 
O sensor de oxigênio (lambda) informa constantemente a ECU o título da mistura ar-combustivel que está sendo queimada no motor, através da medição do teor de oxigênio dos gases de exaustão. Quando a mistura é demasiadamente rica, a ECU corrige instantaneamente a mistura, reduzindo o pulso de injeção. Caso contrário, isto é, quando a mistura é muito pobre, a ECU aumenta o pulso de injeção aproximando a mistura da estequiométrica. PROBST (1995), VOLKSWAGEN (1992), BOSCH (1993) e LENZ (1992)

A unidade de controle eletrônico (ECU) também é programada para desativar o circuito de laço fechado com sensor lambda e, operar em modo de "laço aberto" nos seguintes casos: durante as acelerações, desacelerações, partida a frio, fase de aquecimento do motor e em regime de plena carga do motor. VOLKSWAGEN (1996-a), PROBi:.' (1995), SENAI (1994-a), BOSCH (1993), RIBBENS (1993), MIZUTANI (1992) e BOSCH (1989)

As emissões de óxidos de nitrogênio (Nox) de um motor podem ser reduzidas diminuindo-se as temperaturas máximas do ciclo. Nos países do primeiro mundo como Japão e Estados Unidos, uma técnica muito utilizada com esta finalidade consiste em recircular uma parcela dos gases de exaustão, diluindo-a na mistura fresca de admissão.

A recirculação dos gases de exaustão (EGR), entretanto, pode comprometer seriamente a dirigibilidade, especialmente em regimes de marcha lenta, durante as partidas a frio e em baixas velocidades e cargas parciais, aonde a fração de gases residuais diluídos na mistura fresca é mais significativa . BOSCH (1993), RIBBENS (1993), LENZ (1992) e MIZUTANI (1992) 
O processo de recirculação dos gases de exaustão (EGR) também é gerenciado pela ECU, mediante o controle da válvula pneumática dos gases de exaustão, de modo a reduzir substancialmente as emissões de óxidos de nitrogênio (Nox) do motor, sem contudo comprometer a sua dirigibilidade. VOLKSWAGEN (1996-a), PROBST (1995), RIBBENS (1993), LENZ (1992) e MUZITANI (1992).

A Figura 3.6, publicada por BOSCH (1989), mostra um controle típico de um sistema de recirculação dos gases de exaustão.

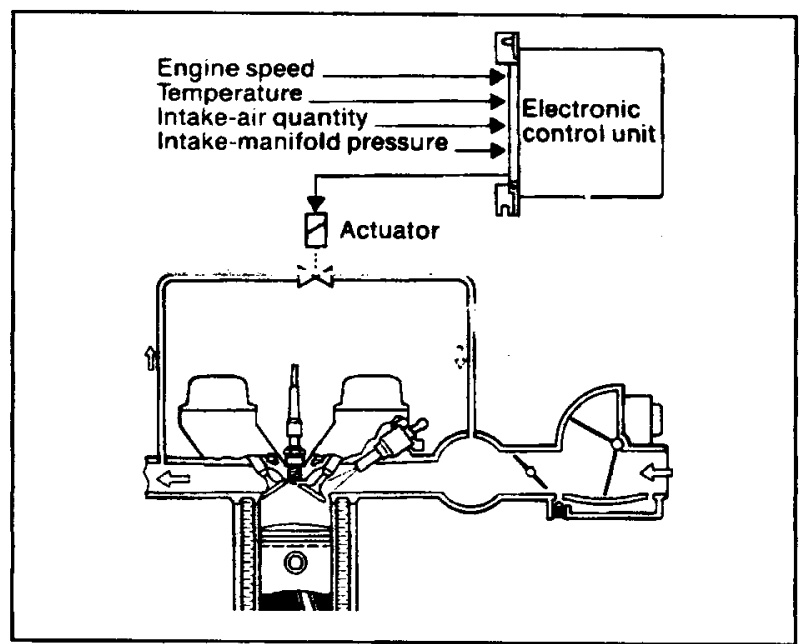

FIGURA 3.6 - Sistema de Recirculação dos Gases de Exaustão (EGR).

Um outro recurso importante dos sistemas de injeção eletrônica é sua capacidade de detectar e armazenar na memória da ECU códigos de diagnósticos de falhas dos componentes da injeção. Este códigos facilitam bastante a identificação de anomalias no sistema de injeção e podem ser recuperados e lidos facilmente por intermédio de ferramentas especiais de diagnósticos denominadas "scanner". Quando a falha é detectada e corrigida, a ECU automaticamente apaga da sua memória "limp home" o código de falha correspondente. PROBST (1995) e FIAT (1993) 
Um outro recurso também importante dos sistemas de injeção eletrônica de combustível, é a possibilidade de funcionamento do motor em caráter emergencial "go home", quando um ou mais sensores, que informam a ECU as condições de operação do motor, apresentam falhas, impossibilitando a determinação exata da quantidade de combustível a ser liberada. Nestes casos, a ECU também é programada para assumir valores padrão, simulando o funcionamento normal dos sensores que apresentam falhas. Desta forma, é possível funcionar o motor em caráter emergencial e conduzir o veículo até uma oficina especializada onde o problema pode ser resolvido. VOLKSWAGEN (1996-a), VOLKSWAGEN (1996-b), PROBST (1995), CHEVROLET (1993), RIBBENS (1993) e LENZ (1992)

A Figura 3.7, reproduzida do LENZ (1992), mostra a utilização dos divarsos sistemas de formação de mistura em carros de passeio na Europa no períc do de 1987 a 1993.

Este gráfico, revela uma redução drástica na produção de veículos com sistemas de carburação e a utilização cada vez mais intensa dos sistemas de injeção de combustivel em carros de passeio na Europa.

A produção de veículos com sistemas de injeção multi-point (MPI) cresceu de 1987 até 1990 e manteve-se a partir deste ano, praticamente constante. Por outro lado, a produção de veiculos com sistemas de injeção single-point (SPI) teve uma taxa de crescimento praticamente constante durante todo o período. A quantidade de veículos de passeio com motores diesel manteve-se praticamente inalterada durante todo o período. 


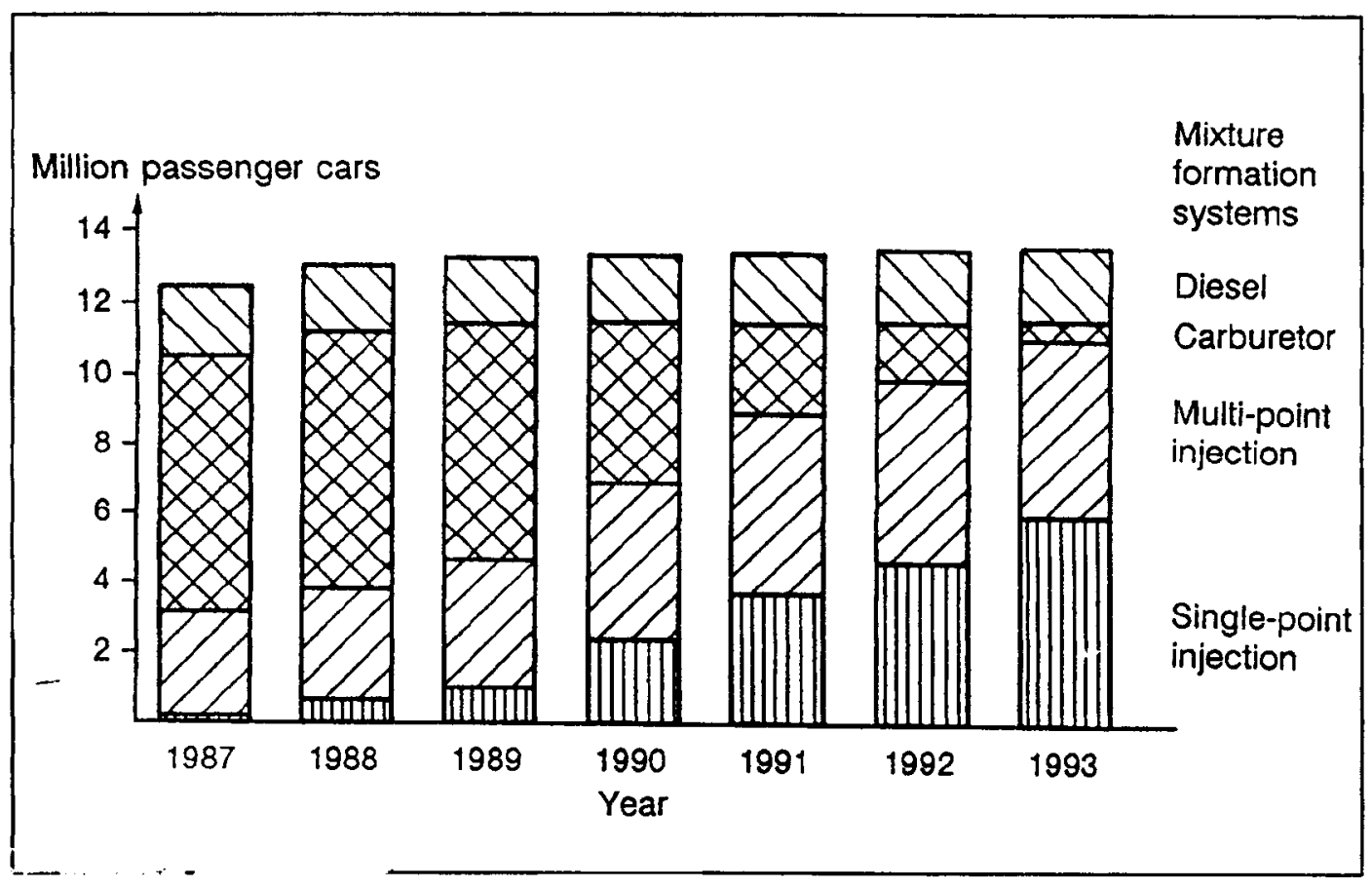

FIGURA 3.7 - Projeção de Utilização dos Sistemas de Formação de Mistura em Carros de Passeio na Europa.

A Figura 3.8, publicada por BECK et al (1991) e reproduzida por MAXWELL (1995), mostra o tempo de resposta típico dos sistemas de carburação e injeção eletrônica de combustível versus o tempo de resposta requerido para boa dirigibilidade e índice de emissões aceitáveis.

Este gráfico mostra com muita propriedade porque os tradicionais sistemas de carburação, que reinaram absolutos como os sistemas de formação de mistura dos veículos, até o início dos anos 70 , foram sendo substituídos nos últimos anos pelos sistemas de injeção eletrônica de combustível e hoje estão completamente absoletos. 


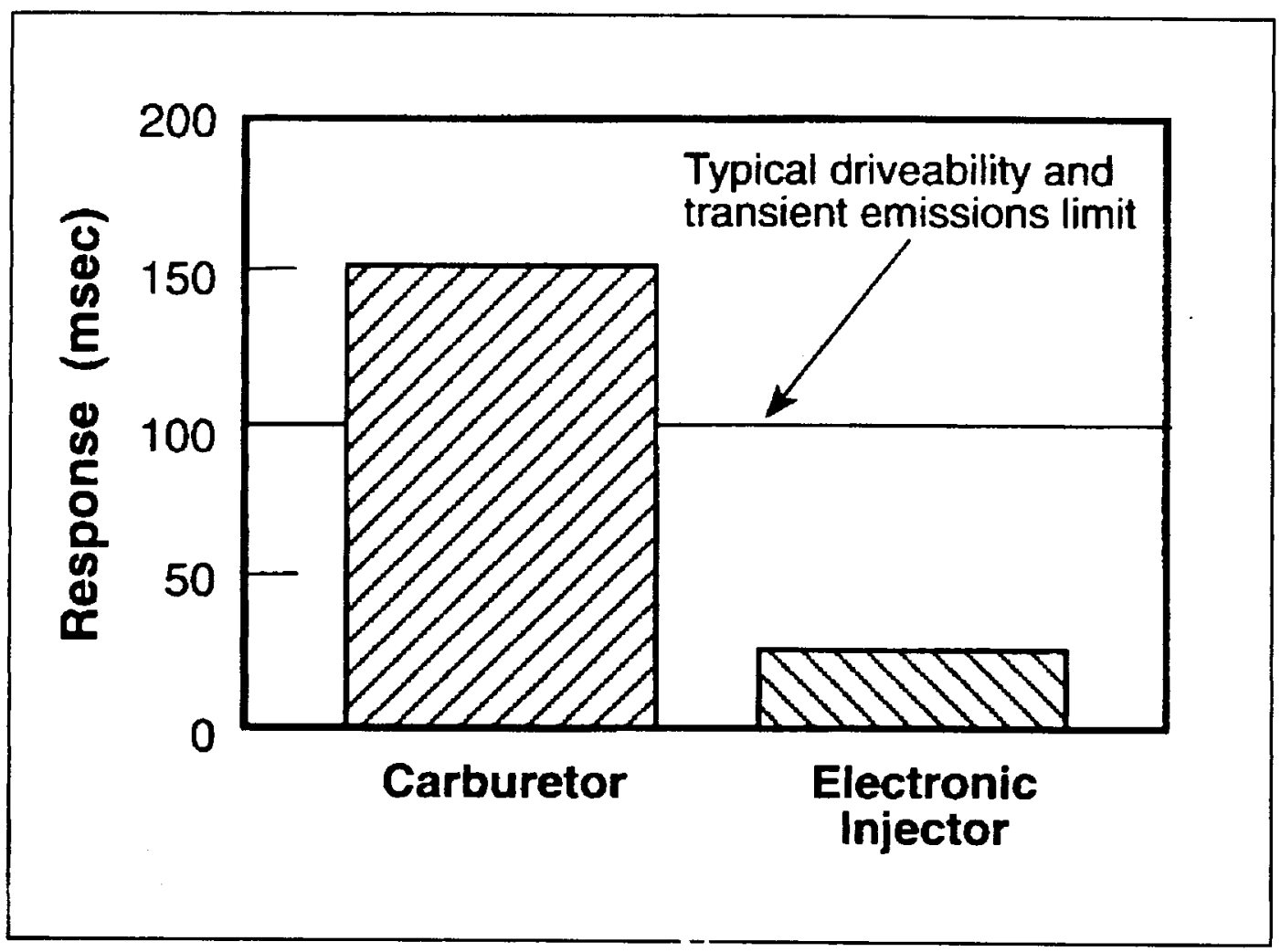

FIGURA 3.8 - Tempos de Resposta Típicos dos Sistemas de Injeção Eletrônica de Combustível e Carburador Versus o Tempo de Resposta Requerido para Boa Dirigibilidade e Emissões Aceitáveis.

\section{3 - SISTEMA DE INJEÇÃO MULTI-POINT (MPI)}

A Figura 3.9, publicada por GLOECKLER (1984), mostra um diagrama esquemático do sistema de injeção multi-point (MPI), também conhecido como sistemas de injeção na porta.

No sistema MPI, o ar e o combustível são controlados separadamente. Existe um injetor de combustivel para cada cilindro do motor, o qual é inserido a montante da válvula de admissão. Esta configuração, além de não interferir no projeto do 
coletor de admissão, permite uma melhor distribuição de combustível aos cilindros do motor do que o sistema de injeção single-point (SPI) e, além disso, elimina o problema condensação de combustivel nas paredes do coletor de admissão, conferindo ótimas respostas durante os regimes transientes: nas acelerações ou desacelerações e também durante as fases de aquecimento e partida a frio. Isto resulta em maiores torques, potência e redução dos índices de emissões de poluentes. VOLKSWAGEN (1996-a), PROBST (1995) e BOSCH (199?)

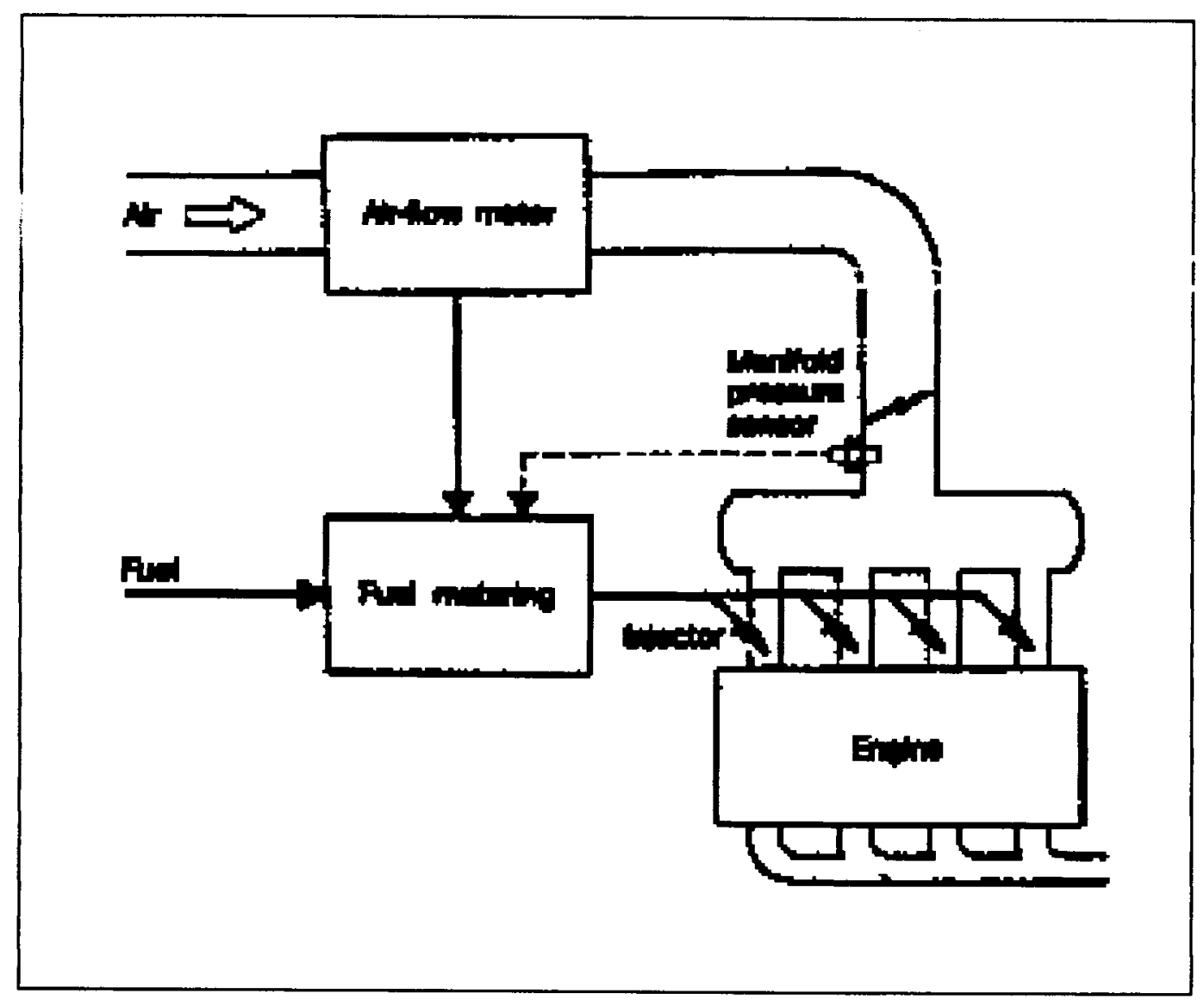

FIGURA 3.9 - Diagrama Esquemático de um Sistema de Injeção Multi-Point.

A Figura 3.10, publicada por PROBST (1995), apresenta um diagrama esquemático da unidade de controle eletrônico da injeção (MPI), com indicação das principais variáveis de entrada. 


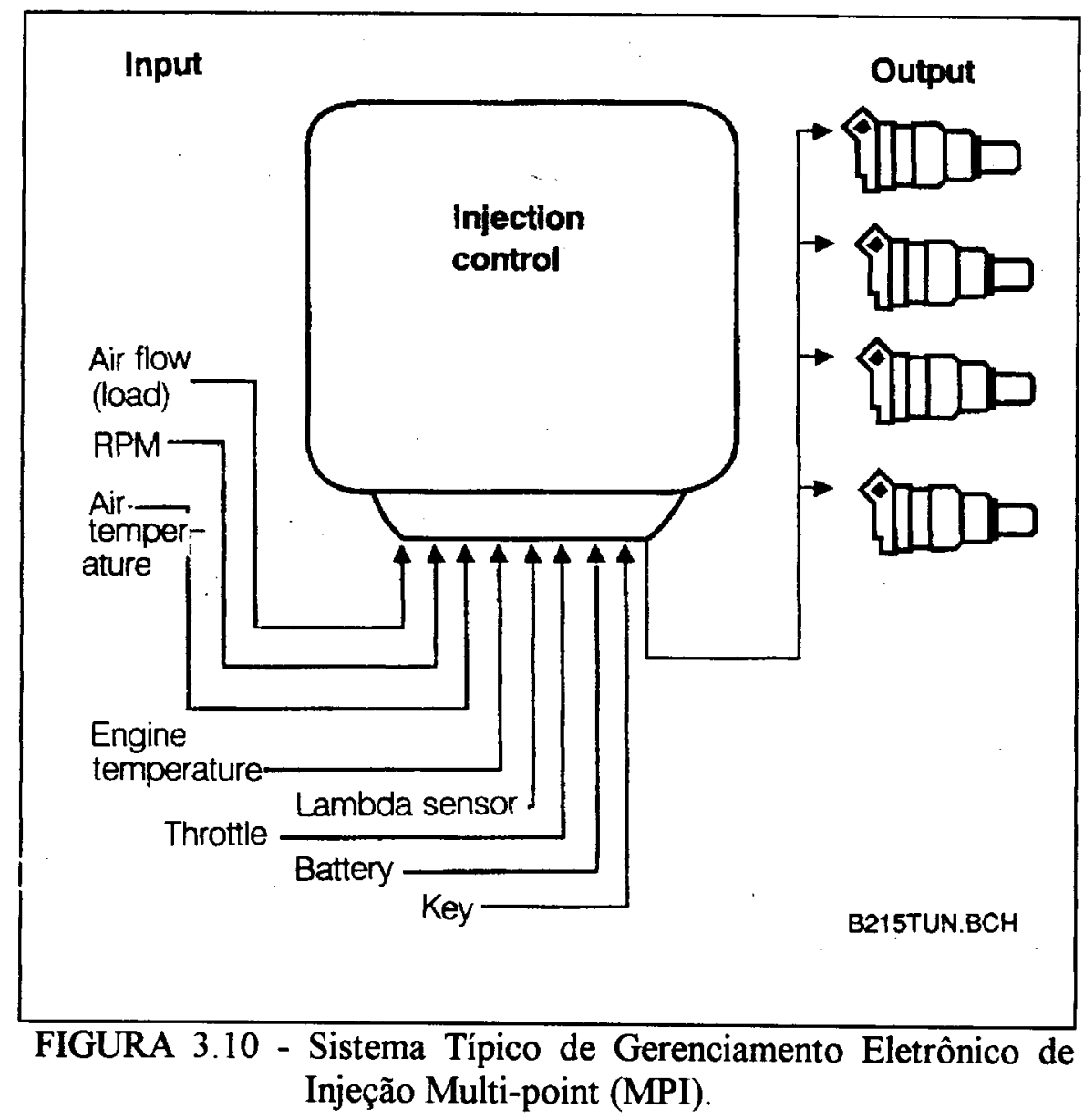

A unidade de controle eletrônico da injeção (ECU), recebe continuamente informações de vários sensores, os quais permitem estabelecer a cada instante as condições de operação do motor. Estes dados são processados instantaneamente pela ECU, definindo a quantidade exata de combustível que deve ser consumida pelo motor. O sinal de comando aos injetores para injeção do combustível é dado em função da estratégia de controle pré-definida na ECU. BOSĊH (1996), PROBST (1995) e BOSCH (1993)

A Figura 3.11, publicada por PROBST (1995), mostra o circuito de alimentação de combustivel de um sistema MPI. O combustível é conduzido sob 
pressão (cerca de 1,5 a 2,5 bar) por uma bomba elétrica até as válvulas injetoras. Um regulador de pressão, inserido no tubo de distribuição de combustivel, mantém constante o gradiente de pressão entre a linha de alimentação de combustível e o coletor de admissão. Quando a pressão de alimentação excede ao valor pré-calibrado, o regulador de pressão abre e o combustível em excesso na linha de alimentação é drenado e retorna para o reservatório de combustivel. Este retorno de combustivel elimina a possibilidade de formação de vapor de combustivel na linha de alimentação.

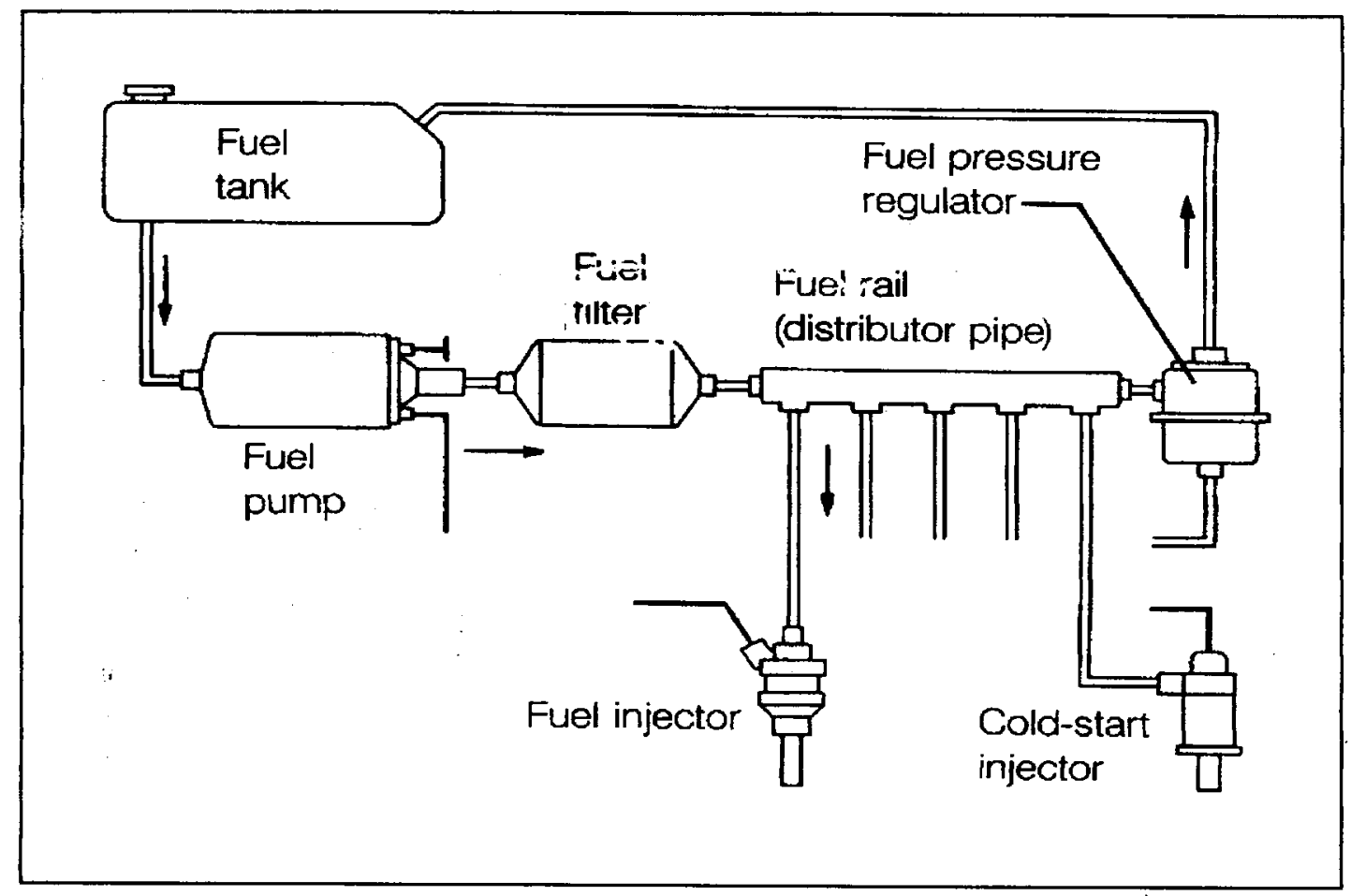

FIGURA 3.11 - Circuito de Combustível de um Sistema de Injeção Multi-point (MPI).

A injeção do combustível no sistema MPI é feita de forma intermitente (pulsante). Como a área de passagem do combustível através do injetor é fixa, a quantidade de combustível injetada por ciclo varia em função do tempo em que a válvula injetora de combustível permanece aberta, uma vez que, o gradiente de pressão entre linha de combustível e o coletor de admissão é mantido constante. 
A Figura 3.12, extraida do PROBST (1995), mostra a montagem de um válvula injetora típica de um sistema MPI. A válvula deve ser montada de modo que o jato de combustível molhe o mínimo possível as paredes do coletor e com menor resistência possível ao fluxo de ar, durante o curso de admissão.

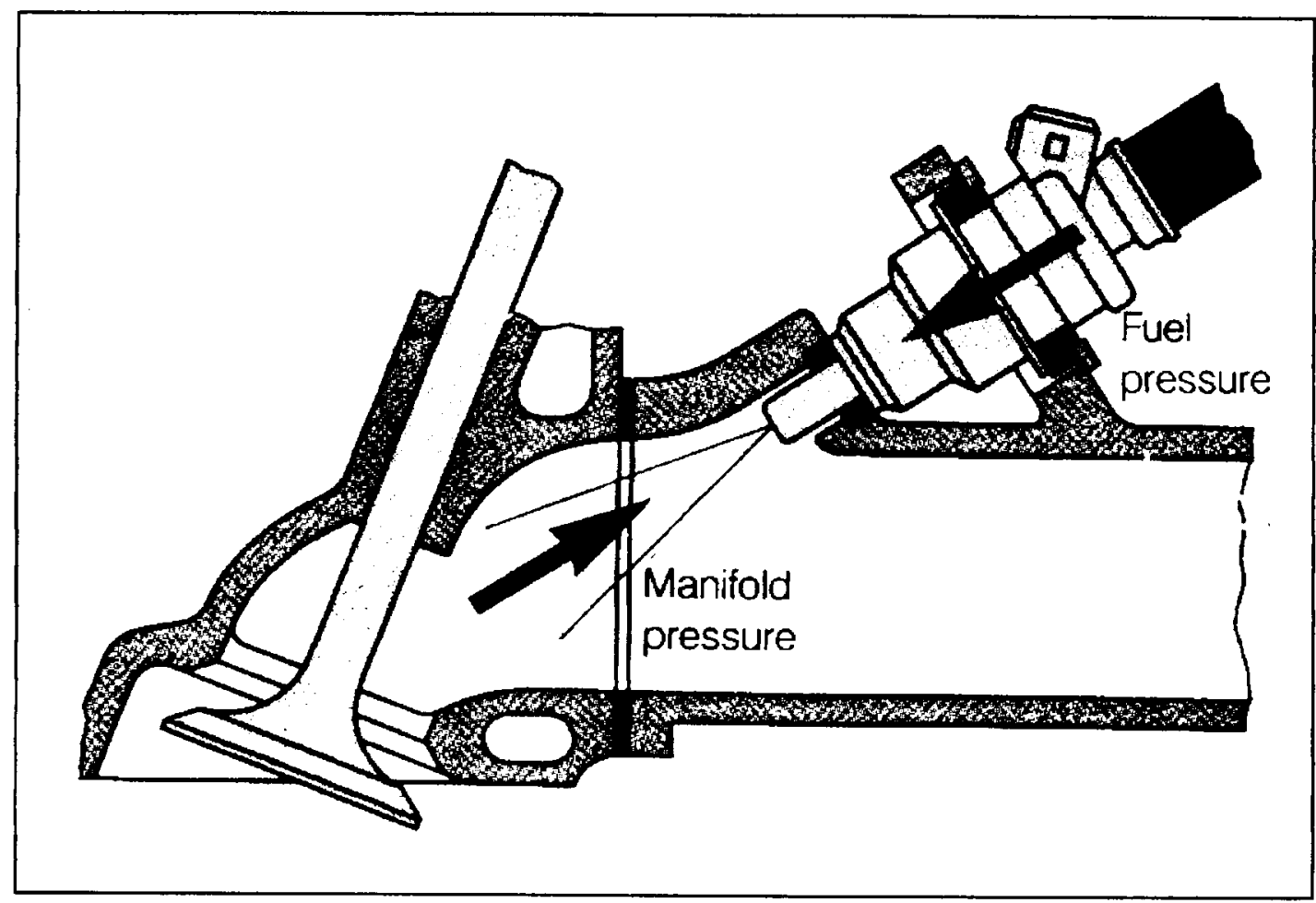

FIGURA 3.12 - Montagem Típica de uma Válvula Injetora de um Sistema Multipoint (MPI), com Indicação do Gradiente de Pressão Entre a Linha de Combustivel e o Coletor de Admissão.

O tempo de injeção é formado pelo tempo básico de injeção e pelo tempo de injeção complementar ou de enriquecimento da mistura. $O$ tempo básico de injeção é determinado em função da massa de ar aspirada e da velocidade angular do motor e estabelece a razão ar-combustivel estequiométrica em qualquer regime de operação do motor. Enquanto que, o tempo de injeção complementar é estabelecido em função 
dos requisitos de mistura para os diferentes regimes e condições de operação do motor. BOSCH (1996), PROBST (1995) e BOSCH (1993)

A título de exemplificação, no caso de frio intenso, durante as partidas à frio ou na fase de aquecimento do motor, há necessidade de misturas mais ricas e as válvulas injetoras, nestas circunstâncias, liberam duas ou três vezes mais combustivel do que a razão estequiométrica. BOSCH (199?)

บ.ง.i - tstratégias de Injeção Multi-Point (MPI)

A Figura 3.13, publicada por LENZ (1992), mostra que na injeção multi-point (MPI) o combustível pode ser injetado de três modos diferentes. Os modos ou estratégias de injeção são:

- Injeção simultânea;

- Injeção em grupo;

- Injeção seqüencial.

$\mathrm{Na}$ injeção simultânea, os injetores são conectados em paralelo e injetam combustivel simultaneamente, uma vez a cada revolução da árvore de manivelas, independentemente da fase em que se encontra o cilindro. Portanto, há dois períodos de injeção por ciclo, sendo que a metade da quantidade de combustível necessário é fornecido em cada período de injeção. Neste modo de operação, as condições de 
formação de mistura são diferentes em cada cilindro. BOSCH (1996), BARKHIMER (1995), SENAI (1994-a), BOSCH (1993), RIBBENS (1993) e LENZ (1992)

$\mathrm{Na}$ injeção em grupo ou semi-sequencial, os injetores são acionados por grupos, de modo que cada grupo de injetores tem seu período próprio de injeção de combustível.. Cada grupo de injetores pode ter um ou dois períodos de injeção de combustivel por ciclo. Este modo de operação pode ser compreendido como uma injeção simultânea realizada em grupo. BARKHIMER (1995), LENZ (1992) e MIZUTANI (1992)

$\mathrm{Na}$ estratégia de injeção seqüencial, o combustivel é injetado de forma sincronizada com o curso de admissão. Portanto, cada injetor tem seu próprio periodo de injeção. Neste mode de operąãa, a exemplo dos dois modos de injeção apresentados anteriores, cada injutor pode realizar um ou dois disparos (períodos) de injeção por ciclo. VOLKSWAGEN (1996-a), BARKHIMER (1995), RIBBENS (1993), LENZ (1992) e MIZUTANI (1992)

A escolha, por parte dos fabricantes, da estratégia de injeção multi-point (MPI) a ser adotada para um determinado modelo de veículo, leva em conta vários fatores, principalmente o custo de fabricação, as necessidades de controle da emissões de poluentes e as características do veículo. PASSARINI (1993), RIBBENS (1993), LENZ (1992), MIZUTANI (1992). De uma forma geral, a estratégia de injeção MPI seqüencial proporciona ao motor um melhor gerenciamento da mistura do que a injeção em grupo e a injeção simultânea. A injeção em grupo, por sua vez, é melhor em termos de controle do que a injeção simultânea. LENZ (1992), MIZUTANI (1992) 
Simultaneous injection

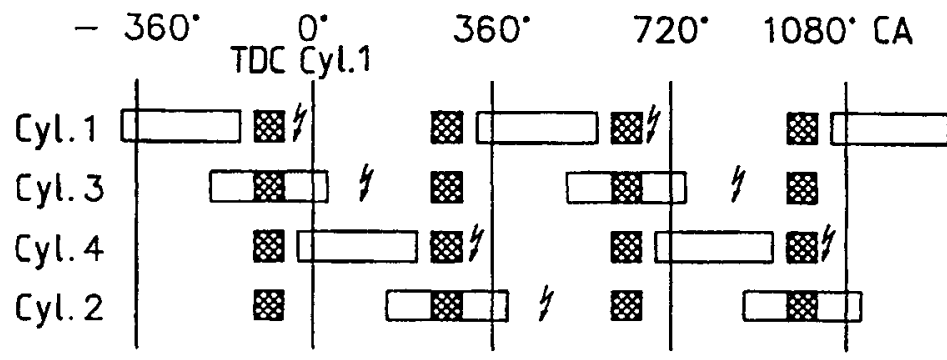

Group injection

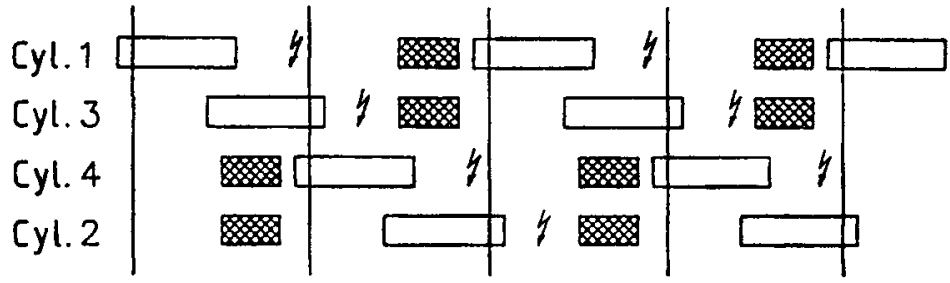

Sequential injection

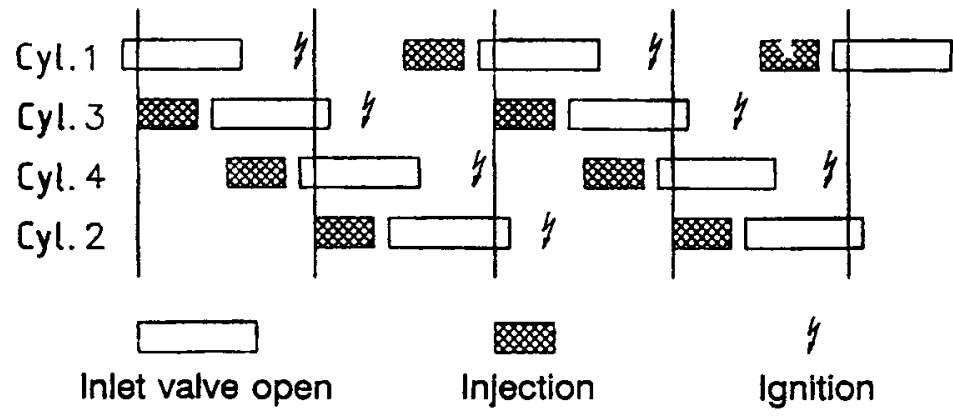

FIGURA 3.13 - Estratégias de Injeção Simultânea, em Grupo e Seqüencial para Sistemas de Injeção Multi-point (MPI).

\section{4 - SISTEMA DE INJEÇĀO SINGLE-POINT (SPI)}

No sistema de injeção eletrônica single-point (SPI), também conhecido como injeção monoponto, injeção no corpo da válvula (TBI), ou ainda injeção central de 
combustivel (CFI), o controle do ar de admissão e do combustivel são feitos separadamente. BOSCH (1993), LENZ (1992), MIZUTANI (1992)

A unidade de controle eletrônico (ECU) recebe constantemente informações sobre as condições de operação do motor através dos diversos sensores. Baseada nestes dados de entrada, a ECU calcula e controla a injeção do combustível. LENZ (1992), MIZUTANI (1992) e BOSCH (1993)

O sistema SPI caracteriza-se por possuir somente um injetor de combustível para alimentar todos os cilindros do motor ( ou dois no caso de motores de 6 a 8 cilindros). Para se obter uma mistura mais homogênea, o injetor de combustível é inserido na zona comum do coletor de admissão, geralmente à montante da válvula

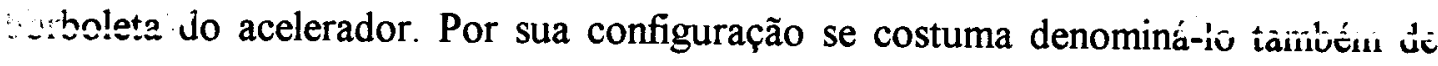
carburador de injeção, mas na realidade é um sistema de injeção. VOLKSWAGEN (1994), RIBBENS (1993), MIZUTANI (1992), VOLKSWAGEN (1992), CHEVROLET (1991), MUNOZ (1989)

A Figura 3.14, publicada por GLOECKLER (1984) apresenta um diagrama esquemático de um sistema de injeção de combustível single-point (SPI). O sistema SPI é um bom compromisso entre o desempenho e o custo. Algumas limitações encontradas no sistema de carburação convencional também podem ser observadas, ainda que em menor grau, no sistema SPI tais como: distribuição do combustivel, principalmente em regime de plena carga, e comportamento dinâmico da mistura, particularmente durante a fase de aquecimento do motor, devido a condensação parcial do combustivel nas paredes do coletor de admissão. Por outro lado, a alta flexibilidade, alta acuracidade e estabilidade no controle do combustivel 
são melhoradas com o sistema de injeção SPI. PROBST (1995), BOSCH (1993), LENZ (1992), VOLKSWAGEN (1992), CHEVROLET (1991), GLOECKER (1984) e BOWLER (1980)

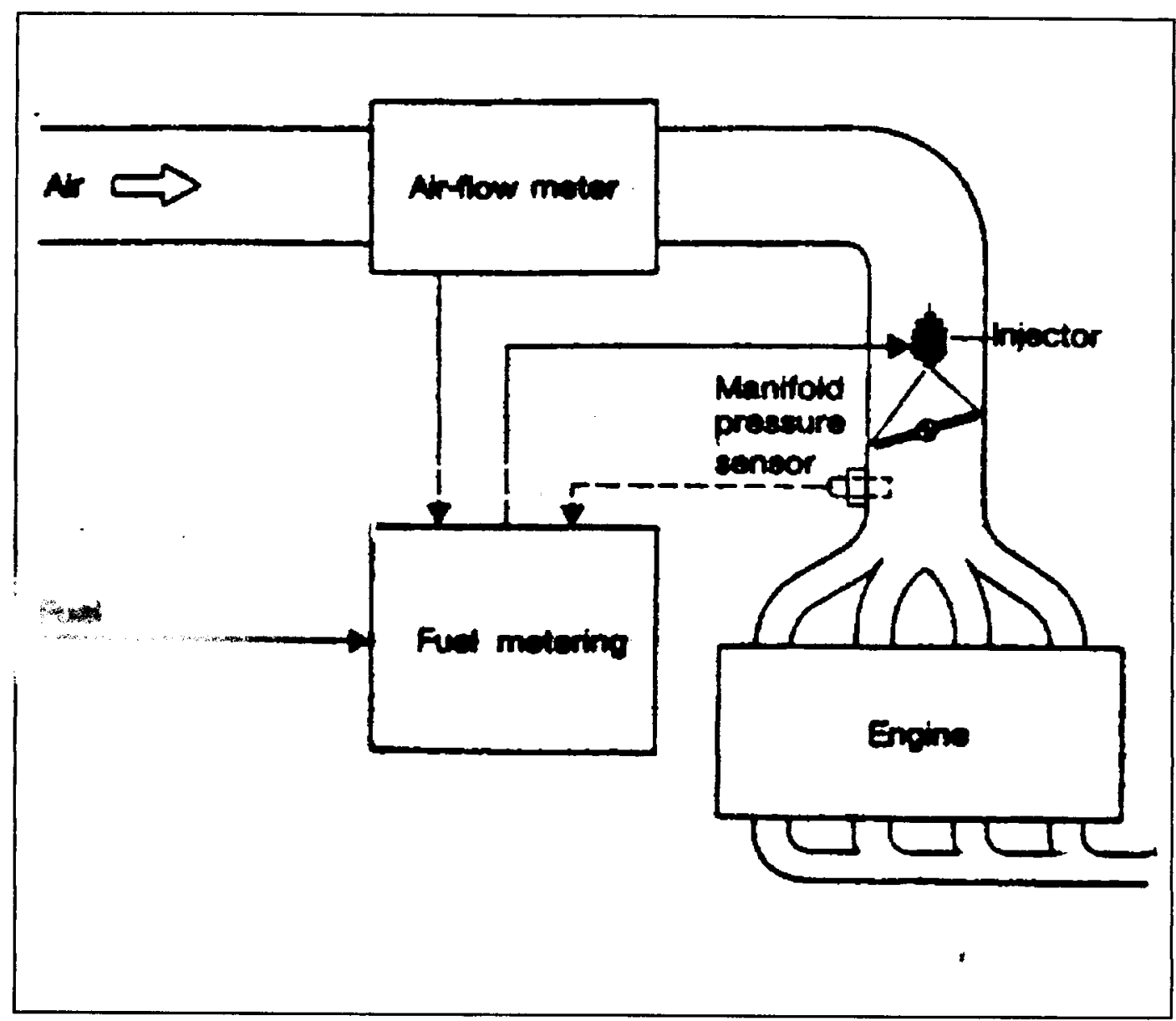

FIGURA 3.14 - Diagrama Esquemático de um Sistema de Injeção Single Point 


\section{5 - INJETOR ELETRÔNICO DE COMBUSTÍVEL}

Segundo BARKHIMER et al (1996) e PASSARINI (1993), o projeto de um injetor eletrônico de combustivel, e em especial do injetor eletrônico de gás deve satisfazer aos seguintes requisitos:

a) controle preciso do combustivel em todas as condições de operação;

b) linearidade entre a vazão de combustível e a duração do pulso de injeção;

-azão dinâmica de combustível adeq̨uada;

d) baixo custo de fabricação;

e) durabilidade. 


\section{CAPÍTULO O4 - ANÁLISE TERMODINÂMICA DO MOTOR}

\section{1 - CICLO PADRÃo DE AR OTTO}

O ciclo ideal de volume constante, representativo dos motores de ignição por centelha, é comumente denominado de "ciclo padrão de ar Otto". Neste ciclo, o fnr:ecimento e rejeição de calor são realizados a volume constante. Na Figugra 4.1, "stão representados os diagramas hipotéticos de pressão versus volume $(\mathrm{P} \times \mathrm{V})$ e de ura Esus entropia (T x S) para o ciclo padrão de ar Otto.
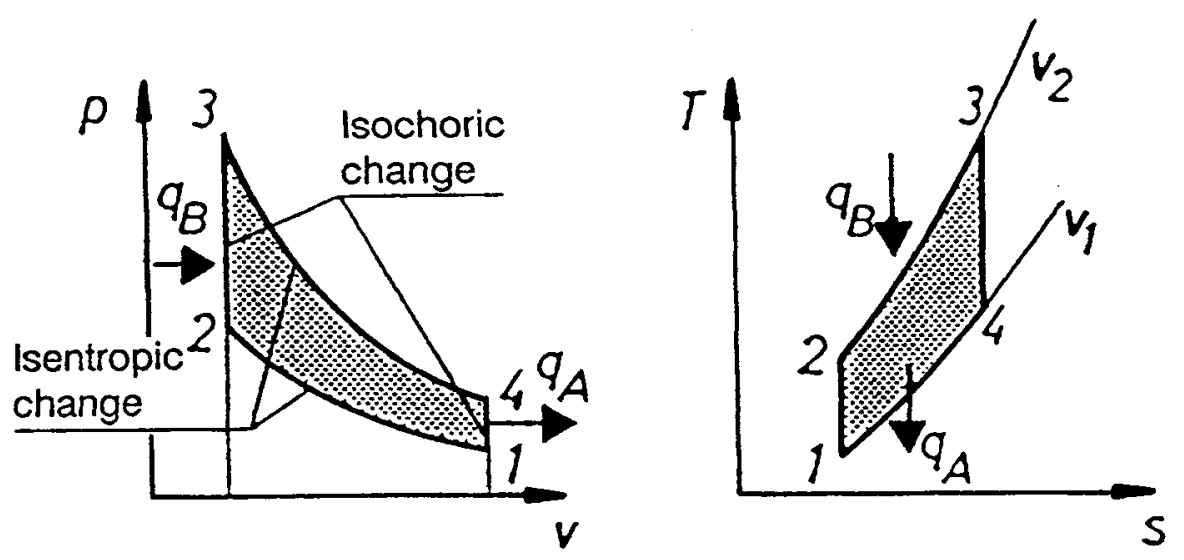

FIGURA 4.1 - Diagramas de Pressão versus Volume (P x V) e Temperatura versus Entropia (T x S) para o Ciclo Padrão de Ar Otto. 
o ciclo se baseia nas seguintes premissas:

a) O fluído de trabalho é o ar, considerado como um gás ideal com os calores específicos $\left(C_{p}\right.$ e $\left.C_{v}\right)$ constantes;

b) Os processos de compressão (1-2) e de expansão (3-4) são ambos isentrópicos, isto é, não se consideram os efeitos de friç̧ão (reversível) nem tampouco as perdas de calor (adiabático);

c) A liberação de calor pelo processo de oxidação do combustível é substituído por um processo de adição calor a volume constante (2-3) de uma fonte externa;

d) Finalmente, o processo de exaustão é substituído por um resfriamento a volume conistanite (4-i). até a temperatura inicial.

Apesar das divergências entre o ciclo teórico e o motor real, a análise do ciclo termodinâmico é muito simples e possibilita estabelecer algumas tendências de comportamento de um motor real, em particular com relação a influência da razão de compressão na eficiência do motor.

Para o ciclo Padrão de ar, o rendimento térmico por definição é:

$$
\begin{aligned}
& \eta_{t}=\frac{\text { calor fornecido }- \text { calor rejeitado }}{\text { calor fornecido }} \\
& \eta_{t}=\frac{q_{A}-q_{B}}{q_{A}}=\frac{\Delta s\left(T_{3}-T_{1}\right)}{\Delta s \cdot T_{3}}
\end{aligned}
$$


fazendo-se os arranjos necessários, resulta:

$$
\begin{gathered}
\eta_{t}=1-\frac{1}{\left(r_{c}\right)^{\gamma-1}} \\
\eta_{t}=\text { rendimento térmico [adm] } \\
\left.r_{c}=\text { razão de compressão [adm }\right] \\
\gamma=\text { razão dos calores específicos }\left(c_{\mathrm{p}} / \mathrm{c}_{\mathrm{v}}\right)[\mathrm{adm}]
\end{gathered}
$$

Totralmente que os eventos em um motor real divergem consideravelmente Wlo teorico, principalmente com relação aos seguintes aspectos:

1) As trocas de calor entre $o$ tluids de trabalho e as paredis do cilindro, reduzem o trabalho de compressão e diminuem a temperatura e pressão durante a combustão e o trabalho no curso de expansão;

2) A combustão não se realiza essencialmente a volume constante, resultando em dos os de pressão e temperaturas máximas, com conseqüente perda de

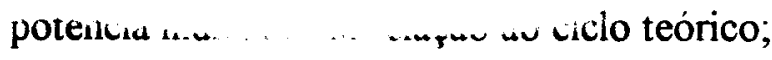

3) As propriedades do fluído de trabalho, uma mistura de ar, combustivel e gases residuais remanescentes do ciclo anterior, não correspondem aquelas do gás ideal, resultando em uma redução de potência em relação aquela estimada pelo ciclo teórico;

4) Os processos de renovação da carga são ignorados no ciclo teórico. 
A Figura 4.2, publicada por PLINT (1995), mostra a variação do rendimento térmico em função da razão de compressão para o ciclo teórico (padrão de ar) e dos motores de ignição por centelha e diesel.

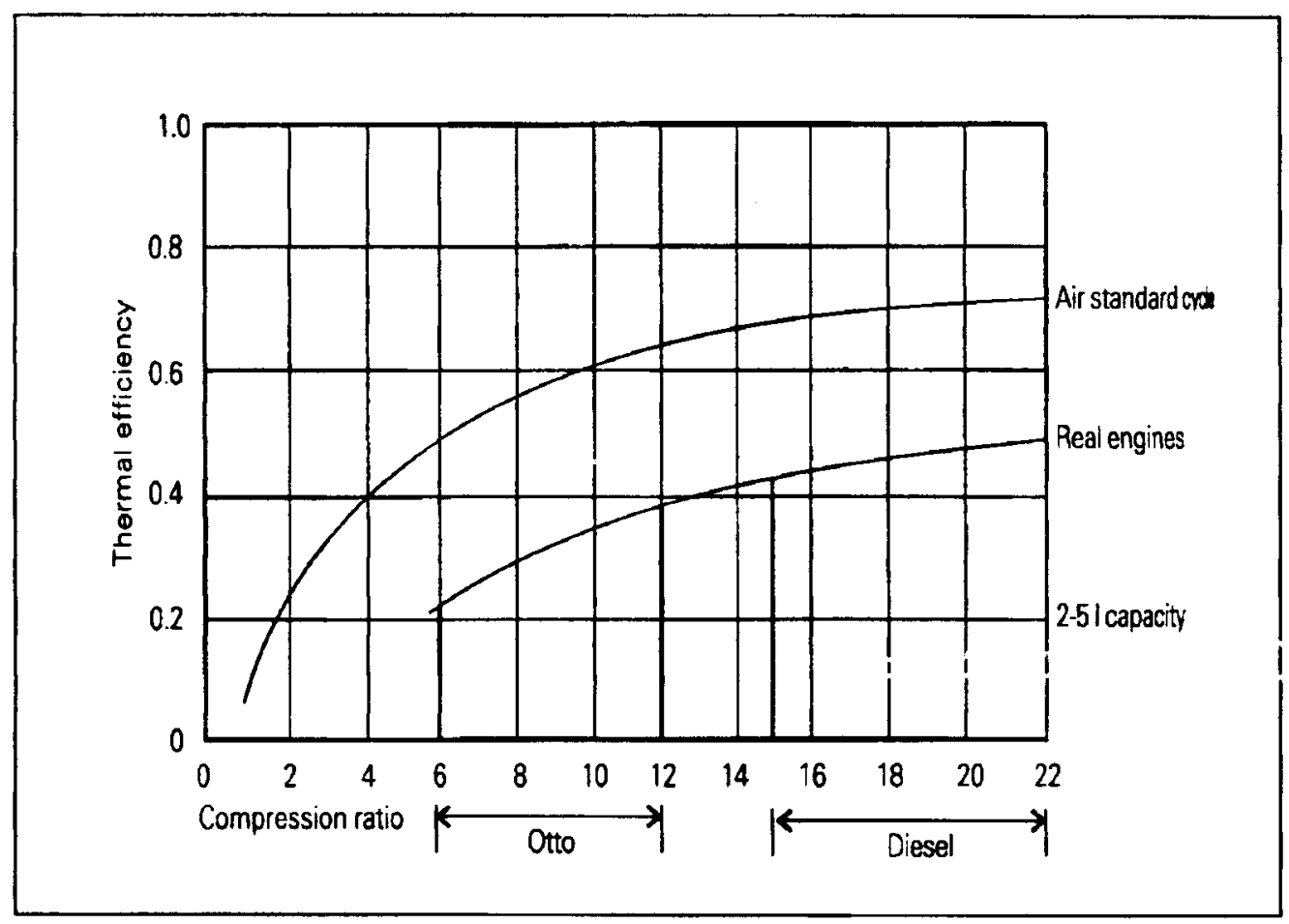

FIGURA 4.2 - Curvas de Rendimento Térmico versus Razão de Compressão.

\section{2 - MÁXIMO TRABALHO DE UM MOTOR DE COMBUSTÃO INTERNA}

Um motor de combustão interna pode ser avaliado como um sistema aberto o qual troca calor e trabalho através de suas fronteiras para a atmosfera. Os reagentes (uma mistura de ar e combustível) entra no sistema (volume de controle) enquanto os produtos (gases de exaustão) saem do sistema. Aplicando-se a $2^{\mathrm{a}}$ Lei da 
termodinâmica ao volume de controle apresentado na Figura 4.3, é possível encontrar o máximo trabalho que o motor pode fornecer.

Considerando-se que uma massa $(\mathrm{m})$ de fluído passa através do volume de controle. Da $1^{\text {a }}$ Lei da termodinâmica tem-se:

$$
\Delta Q-\Delta W_{U}=\Delta H
$$

onde

$\Delta \mathbf{W}_{\mathrm{U}}=$ trabalho útil transferido para o ambiente;

$$
\Delta H=H_{P}-H_{R}
$$

tonds $\mathrm{cm}$ corta que $\approx$ căior transferido $(\Delta Q)$ ocorre somente para a atmosfera cuji : $T_{A}$ da $2^{\text {a }}$ Lei da termodinâmica Vem:

$$
\frac{\Delta Q}{T_{A}} \leq \Delta S
$$

combinando estas equações resulta:

$$
\Delta W_{U} \leq-\left(\Delta H-T_{A} \Delta S\right)=-\Delta B
$$

a função disponibilidade (B) é:

$$
B=H-T_{A} \cdot S
$$

Normalmente $\left(T_{R}=T_{A}\right)$ e $\left(P_{R}=P_{A}\right) . O$ trabalho máximo deve ser obtido quando $\left(T_{p}=T_{A}\right.$ e $\left.P_{p}=P_{A}\right)$. Nestas condições: 


$$
\Delta W_{U} \leq-\left[(H-T S)_{P_{T A, T A}}-(H-T S)_{R_{T A, P A}}\right]=(\Delta G)_{T_{A}, P_{A}}
$$

ou

$$
\Delta W_{U \max }=-(\Delta G)_{T_{A}, P_{A}}
$$

onde (G) é a energia livre de Gibbs, (H - TS), e $(\Delta G)_{\text {TA PA }}$ é o aumento de energia livre de Gibbs na reação de mistura ar-combustível a temperatura e pressão atmosférica. - $(\Delta \mathrm{G})_{\mathrm{TA}}$ PA será a máxima quando a combustão for completa.

Uma medida fundamental da ineficiência de um motor real é a razão entre o trabalho de eixo e o trabalho máximo. Esta razão deve ser chamada de "eficiência de conversão disponivel" ( $\left.r_{\mathrm{ia}}\right)$ :

$$
\frac{1 W}{\Delta W_{U \max }}=-\frac{\Delta W}{(\Delta G)_{T_{A}, P_{A}}}
$$

\section{3 - BALANÇO TÉRMICO DE UM MOTOR DE COMBUSTÃO}

O rendimento térmico de um motor de combustão interna em regime de plena carga varia aproximadamente entre $20 \%$ para pequenos motores a gasolina até pouco mais de 50\% para motores diesel de baixa rotação. PLINT (1995). 
As irreversibilidades dos processos em um motor real impedem que toda a energia disponivel no combustível seja integralmente transformada em trabalho útil, resultando em perdas de energia inevitáveis.

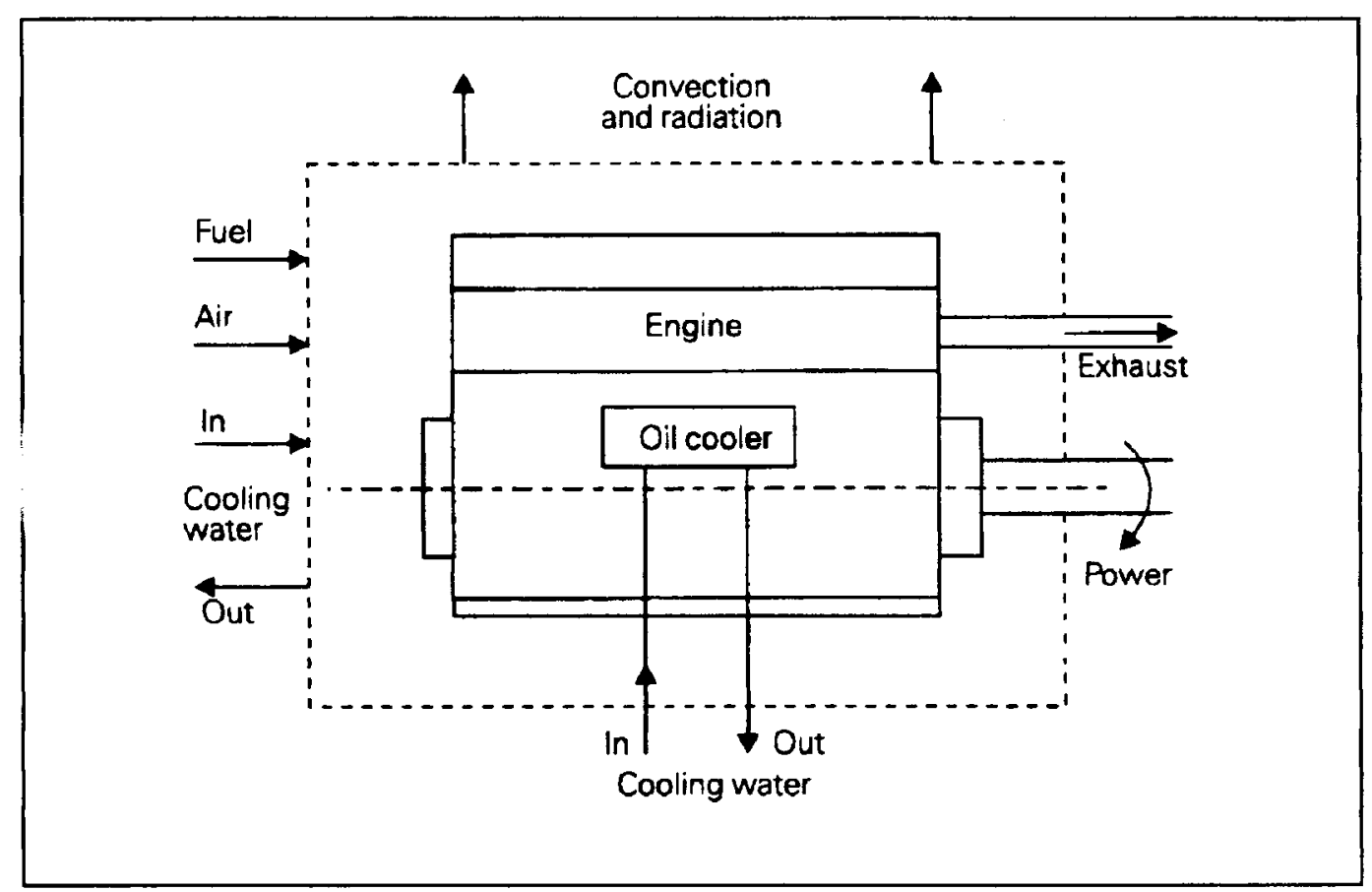

FIGURA 4.3 - Volume de Controle para um Motor de Combustão Interna, com Indicação dos fluxos de energia e massa através das fronteiras.

Estas perdas de energia, típicas de um motor de combustão interna, podem ser avaliadas de maneira simples, aplicando-se a equação da conservação da energia em regime permanente ao volume de controle (V.C) indicado na Figura 4.3. Conforme ilustrado nesta figura, fluxos de massa e energia atravessam as fronteiras do sistema (volume de controle), interagindo com o meio (atmosfera). A equação da energia em regime permanente aplicada ao volume de controle (V.C) da Figura 4.3, resulta: 


$$
H_{1}=P_{s}+\left(H_{2}-H_{3}\right)+Q_{1}+Q_{2}
$$

onde:

$\mathrm{H}_{1}=$ energia do combustível;

$\mathbf{P}_{\mathbf{s}}=$ potência útil;

$\mathbf{H}_{2}=$ entalpia dos gases de exaustão;

$\mathrm{H}_{3}=$ entalpia do ar de admissão

$Q_{1}=$ calor absorvido pela fluído de refrigeração;

$\mathrm{Q}_{2}=$ calor retirado por convecção e radiação;

Valores típicos das perdas energéticas em um motor de ignição por centelha são: $30 \%$ para os gases de exaustão, $25 \%$ para o fluído de refrigeração, $7 \%$ por atrito, $8 \%$ para acionamento de componentes auxiliares e $3 \%$ por radiação e condução. A energia restante, $27 \%$ corresponde ao trabalho útil. PENIDO (1981)

Apesar da utilização de novos materiais e avançadas tecnologias tais como injeção e ignição eletrônica, o motor de combustão interna não atingiu seu ápice de desenvolvimento, apresentando ainda enormes irreversibilidades. REYWOOD (1988) 


\section{CAPÍTULO 05 - O RENDIMENTO VOLUMÉTRICO}

itrico é de grande importância no contexto deste trabalho, uma vez que a estrategıa de injeção direta de gás natural tinha como objetivo básico aumentar a capacidade de enchimento de ar do cilindro (eficiência de bombeamento de ar para o motor) em relação a injeção tradicional de gás natural feita no coletor de admissão. Neste capitulo, serão apresentadas as correlações existentes entre o rendimento volumétrico $\curvearrowright$ os parämetros característicos de desempenho do motor tais como potência, torque e pressão média efetiva etc. Discute-se ainda o processo de admissão ideal e os principais efeitos dinâmicos e estáticos que interferem no rendimento volumétrico.

\section{1 - CONSIDERAÇÕES PRELIMINARES}

De acordo com MAXWELL (1995), PLINT (1995), MUÑOZ (1989) e REYWOOD (1988) os motores de combustão interna são essencialmente bombas de ar, uma vez que a massa de ar ou mistura admitida por unidade de tempo é proporcional a velocidade angular do motor e a densidade do fluído de trabalho em algum ponto característico do sistema de admissão. 
MAXWELL (1995) descreve ainda que o ar de admissão aspirado pelo motor fornece o oxigênio que se constitui num dos elementos básicos da reação de oxidação do combustível no interior do motor. Para fornecer mais potência ao motor, se faz necessário queimar uma parcela maior de combustível e consequentemente mais ar (oxigênio) deve ser aspirado. Nos motores atuais do ciclo Otto, a quantidade de ar disponivel no cilindro do motor para combustão, depende em grande parte das características do combustível reinantes no coletor de admissão e também, da resistência imposta pelos sistemas de admissão e exaustão.

Nas últimas décadas, tecnologias de otimização do rendimento volumétrico s como aumento do número de válvulas, aumento da pressão de admissão por meio de compressores ou turbinas (motor superalimentado) on ainda mecanismos de abertura e fechamento de válvulas variável, vem sendo pe:quisadas e utilizadas em motores de combustão interna para uso veicular.

\section{.2 - DEFINIÇÕES E CONDIÇÕES DE REFERÊNCIA}

Segundo HEYWOOD (1988) o rendimento volumétrico é um parâmetro admensional muito utilizado para aferir a capacidade de aspiração de ar dos motores de combustão interna de quatro tempos. 
MUÑOZ (1989) e HEYWOOD (1988) definem ${ }^{1}$ o rendimento volumétrico como sendo a razão entre a massa de ar que entra nos cilindros do motor por ciclo e massa de ar que ocuparia o volume deslocado pelo pistão na densidade de referência ${ }^{2}$. A expressão matemática para os motores de quatro tempos é:

$$
\eta_{\nu}=\frac{2 \dot{m}_{a}}{\rho_{a, 0} V_{d} N}
$$

onde:

$\eta_{v}=$ rendimento volumétrico $[\mathrm{adm}]$

$\dot{m}_{a}=$ vazão mássica de ar aspirada pelo motor [ $\left.\mathrm{kg} / \mathrm{min}\right]$

$Y=\operatorname{rntacano~do~motor~}[\mathrm{rpm}]$

$V_{d}=$ cilindrada total $\left[\mathrm{m}^{3}\right]$

$\rho_{a, o}=$ densidade do ar aspirado na temperatura e pressão de referência $\left[\mathrm{kg} / \mathrm{m}^{3}\right]$

Segundo MUÑOZ (1989) e TAYLOR (1985-a) nos motores aspirados, a densidade de referência toma-se normalmente nas condições de pressão e temperatura exteriores ( 1 da Figura 5.1). O rendimento volumétrico assim definido ${ }^{3}$, leva em conta a influência de todo o sistema de admissão. Se as condições de pressão e temperatura

\footnotetext{
${ }^{1}$ FERGUSON (1988) e TAYLOR (1885-a) definem $\eta_{v}=2\left(\dot{m}_{a}+\dot{m}_{f}\right) / \rho_{a, o} V_{d} N$; onde $\dot{m}_{f}=$ vazão mássica de combustivel induzida. Nos motores de injeção direta de combustível $\dot{m}_{f}=0$.

${ }^{2}$ REYWOOD (1988), considera a densidade de referência como sendo a densidade do ar atmosférico ou em algum ponto do coletor de admissão.

${ }^{3}$ REYWOOD (1988) eTAYLOR (1985-a) denominam de rendimento volumétrico global. quando a densidade é medida na entrada do coletor de admissão;
} 
de referência são tomadas em algum ponto intermediário ( 2 e 3 da Figura 5.1), o rendimento volumétrico mede a influência sobre o processo de perda de carga somente a jusante do ponto considerado. Como as maiores perdas de carga do sistema de admissão são geradas na válvula de admissão, é também possível, mas não muito freqüente tomar como condições de referência a densidade da mistura nas vizinhanças da válvula. Nestes casos, entretanto, é preciso adotar um procedimento criterioso, de modo a evitar que algum problema de medida possa surgir em virtude das grandes flutuações de pressão naquela região do conduto de admissão.

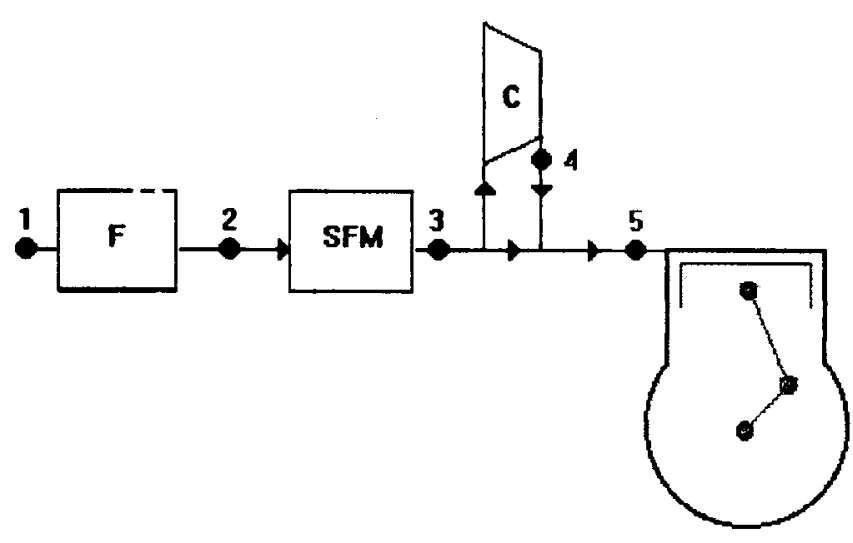

F - Filtro

SFM - Sistema de Formação de Mistura C - Compressor

FIGURA 5.1 - Condições de Referência para Determinação do Rendimento Volumétrico.

No caso dos motores sobrealimentados, se a densidade de referência é referida as condições exteriores, o rendimento volumétrico correspondente pode resultar 
maior que a unidade. Por esta razão, a densidade de referência é tomada normalmente após o compressor (4 e 5 da Figura 5.1)

\section{3 - O PROCESSO DE ADMISSÃO IDEAL}

MUÑOZ (1989) relata que o denominador da eq. (5.2) do rendimento volumétrico corresponde a massa de ar que é introduzida no cilindro do motor em um processo de admissão ideal. Tal processo, poderia ser obtido caso fossem satisfeitas as seguintes condições:

a) A velocidade de deslocamento do pistão é suficient.mente lenta de modo que os tos de inèrcia são despreziveis;

b) Não existe troca de calor com o fluído de trabalho durante o processo de admissão;

c) Não existe perda de carga durante o processo de admissão;

d) As válvulas de admissão e de exaustão abrem e fecham instantaneamente nos pontos mortos.

De acordo com o mesmo autor, o modelo mecânico de um processo de admissão ideal corresponderia a um motor hipotético operando tão lentamente que se supõe atendidas as condições (a) e (c) acima, devido a baixa velocidade de circulação do fluído de trabalho. Tal processo seria ainda adiabático por hipótese do processo de admissão e com fechamento e abertura das válvulas instantâneos, de forma a assegurar que as pressões durante o curso de admissão e exaustão seriam constantes, 
e por fim, o sistema seria perfeitamente estanque, sem fugas do fluido de trabalho entre o pistão e o cilindro.

\section{4 - OS PROCESSOS DE ADMISSÃO E EXAUSTÃO EM MOTORES DE QUATRO TEMPOS}

Nos motores de ignição por centelha, a mistura admitida nos cilindros consiste basicamente de combustivel, de ar atmosférico e de gases residuais. A preparação da mistura é um objetivo básico do processo de admissão. O processo de formação da ’ura compreende a preparação da mistura propriamente ditã a tümbémin a sua wistrivuição equilibrada, em termos qualitativos e quantitativos, para os cilindros to motor.

HEYWOOD (1988) descreve que nos motores de ignição por centelha, o sistema de admissão típico consiste de um filtro de ar, um sistema de formação de mistura ( carburação ou injeção), uma borboleta de controle do fluxo de ar, coletor de admissão e válvulas. O sistema de exaustão típico, por sua vez consiste basicamente de um silencioso, um catalisador e um sistema para controle das emissões.

A Figura 5.2, publicada por HEYWOOD (1988), mostra os processos de admissão e exaustão típicos de um motor de ignição por centelha multicilíndrico. 


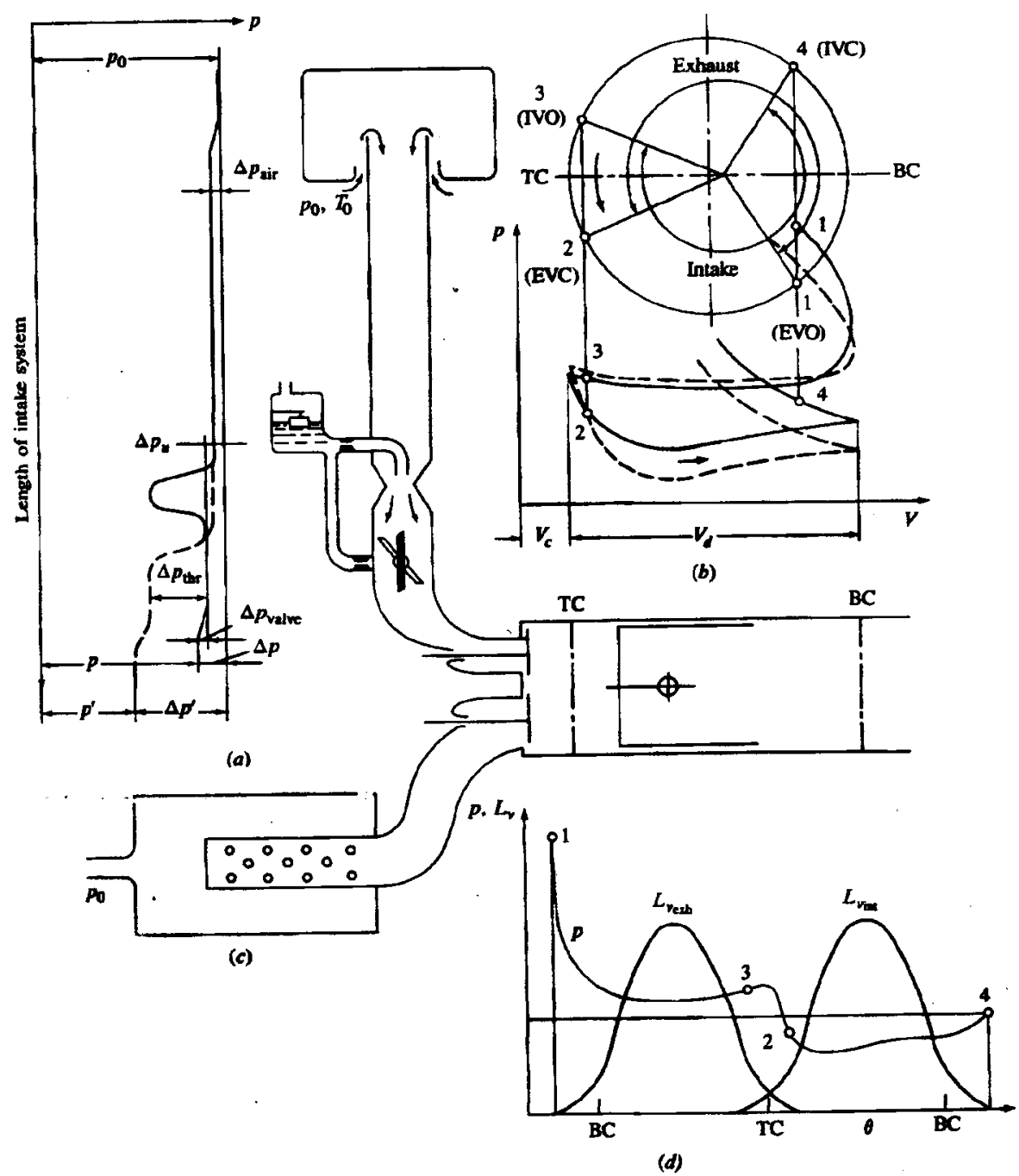

FIGURA 5.2 - Processos de Admissão e Exaustão de um Motor de Ignição por Centelha de 4 tempos. (a) Pressões Médias na Admissão; (b) Diagramas de Válvulas e Pressão versus Volume; (c) Sistema de Exaustão; (d) Pressões Indicadas (p) e Levantamento de Válvulas em Função do Ângulo $n$ Árvore de $\operatorname{Manivelas}(\theta)$. A Linha cheia é a Plena Carga e a Pontilhada em Regime Cargas Parciais.

Durante o processo de admissão, a mistura ar-combustível sofre perdas de carga ao passar por cada um destes elementos, sendo que a perda de carga na passagem da válvula de admissão é a mais significativa. Um sistema de exaustão típico 
consiste basicamente de um coletor de exaustão, tubulação de exaustão, um conversor catalítico de controle das emissões e um silencioso. O escoamento do fluído de trabalho nos sistemas de admissão e exaustão é predominantemente pulsante. Entretanto, alguns aspectos deste escoamento pode ser analisado em regime permanente.

Na Figura 5.2-a, estão representados os valores médios das pressões de admissão. A queda de pressão ao longo dos sistemas de admissão e exaustão depende essencialmente da velocidade do motor, da resistência oferecida ao fluxo pelos elementos do sistema, da área de passagem de cada um destes elementos e da densidade do fluído de trabalho.

A Figura 5.2-d, mostra a diagrama de distribuị̧̃ó, isto é, o diagrama de acionamento das válvulas de admissão e exaustão em função do ângulo igonométrico medido na árvore de manivelas. É usual antecipar a abertura das válvulas e postergar o seu fechamento, em relação aos cursos de admissão e exaustão correspondentes, para tirar proveito da inércia dos gases nos sistemas de admissão e exaustão, melhorando o enchimento do cilindro.

O processo de exaustão inicia-se usualmente entre $40^{\circ}$ a $60^{\circ}$ antes do pistão atingir o PMI no curso de expansão. A válvula de exaustão fecha tipicamente de $15^{\circ}$ a $30^{\circ}$ após o pistão passar pelo PMS, no início do curso de admissão.

A válvula de admissão, por sua vez, abre tipicamente entre $10^{\circ}$ e $20^{\circ}$ antes do pistão atingir o PMS no final do curso de exaustão. O fechamento da válvula de admissão ocorre tipicamente entre $50^{\circ}$ a $70^{\circ}$ após o pistão passar pelo PMI no início 
do curso de compressão, de modo que a mistura fresca (ar-combustivel) continua a encher o cilindro do motor, após o pistão passar pelo PMI.

O periodo em que as válvulas estão simultaneamente abertas é denominado de período de cruzamento de válvulas ou simplesmente cruzamento de válvulas. Neste período, quando a relação entre a pressão de admissão e a pressão de descarga é menor que a unidade $\left(\mathrm{P}_{\mathrm{i}} / \mathrm{P}_{\mathrm{e}}<1\right)$, parte dos gases descarregados retornam "backflow" ao cilindro do motor juntamente com a mistura fresca admitida.

1 mantagem do cruzamento das válvulas acontece em altas rotações, quando o longo penodo de cruzamento contribui para melhoria da eficiência volumétrica do motor.

REYWOOD (1988) afirma que devido às variações com o tempo, di volume do cilindro e da área de abertura das válvulas e também, dos efeitos de inércia dos gases e de propagação de ondas nos sistemas de admissão e exaustão, as pressões no coletor de admissão, no cilindro e no coletor de exaustão, durante o processo de renovação dos gases, variam de forma bastante complicada. Um cálculo analítico destes processos é extremamente dificil. $\mathrm{Na}$ prática, estes processos são freqüentemente tratados empiricamente, usando parâmetros globais, como a eficiência volumétrica, para determinar o desempenho dos sistemas de admissão e exaustão, em termos de capacidade de bombeamento de ar para o motor. 


\section{5 - VARIÁVEIS QUE INFLUENCIAM O RENDIMENTO VOLUMÉTRICO}

REYWOOD (1988) descreve que o rendimento volumétrico de um motor de combustão interna é função de inúmeras variáveis, sendo fortemente influenciado pelas propriedades do combustível, pelas condições operacionais e climáticas e ainda pelas características de projeto do motor, especialmente dos sistemas de admissão e exaustão. Segundo ele, a eficiência volumétrica é um parâmetro admensional muito utilizado para expressar a ineficiência de um motor de quatro tempos e seus sistemas de admissão e exaustão como dispositivos de bombeamento de ar para o cilindro. Uma exprıs; io equivalente a eq. (5.1) para o rendimento volumétrico é:

$$
\eta_{v}=\frac{m_{a}}{\rho_{a, o} V_{d}(N / 2)}
$$

onde: $\mathrm{m}_{\mathrm{a}}=$ massa de ar aspirada pelo motor por ciclo $[\mathrm{Kg}]$

As principais variáveis que interferem no rendimento volumétrico podem ser agrupadas da seguinte forma:

a) Tipo de combustível, razão ar-combustível;

b) Fração de combustivel vaporizado no sistema de admissão e calor de vaporização;

c) Temperatura da mistura a qual é influenciada pela transferência de calor; 
d) Razão de compressão;

e) Razão entre as pressões de admissão e exaustão;

f) Velocidade do motor;

g) Projeto das janelas de passagem e coletores de admissão e exaustão;

h) Projeto das válvulas de admissão e exaustão quanto a geometria, tamanho, levantamento e diagrama de distribuição.

O autor afirma ainda que os efeitos da maioria das variáveis são de natureza quasi-permanente, isto é, seu impacto é independente da velocidade, podendo ser descritos em termos de velocidade média do motor.

Entretanto, algumas dessas variáveis causam efeitos que dependem do kento transitório e dos fenômenos de ondas de pressão que acompanham a natureza da variação temporal dos processos de renovação de carga.

\section{6 - EFEITOS QUASI-ESTÁTICOS}

\subsection{1 - Eficiência Volumétrica do Ciclo Padrão Ar-Combustível.}

Para o ciclo ideal ar-combustível, representativo dos motores de ignição por centelha, é válida a seguinte expressão para o rendimento volumétrico: 


$$
\eta_{v}=\frac{2 \cdot m_{a}}{\rho_{a, o} V_{d}}=\frac{m\left(1-x_{r}\right)}{\rho_{a, o}[1+(F / A)]} \frac{r_{c}}{\left(r_{c}-1\right) V_{1}}
$$

onde $(m)$ é a massa no ponto (1) do ciclo. Sendo:

$$
\begin{aligned}
& \rho_{i} V_{1}=m \frac{\widetilde{R}}{M} T_{1} \\
& p_{a, o}=\rho_{a, o} \frac{\widetilde{R}}{M_{a}} T_{a, o} \\
& \frac{T_{1}}{T_{i}}=\frac{1-x_{r}}{1-1 /\left(r_{c}\right)\left[p_{e} / p_{i}+(\gamma-1)\right]}
\end{aligned}
$$

substituindo estas equações na eq. (5.3), obtem-se:

$$
\eta_{v}=\left(\frac{M}{M_{a}}\right)\left(\frac{p_{i}}{p_{a, o}}\right)\left(\frac{T_{a, o}}{T_{i}}\right) \frac{1}{[1+(F / A)]}\left\{\frac{r_{c}}{r_{c}-1}-\frac{1}{\gamma\left(r_{c}-1\right)}\left[\left(\frac{p_{e}}{p_{i}}\right)+(\gamma-1)\right]\right\}
$$

onde, os sub-índices significam: $(\mathbf{i})=$ admissão da mistura; $(a, 0)=$ ar nas condições exteriores; $(a)=$ ar atmosférico; $(e)=$ exaustão do gases; $(1)=$ no ponto 1 do ciclo.

T. $\mathbf{P}=$ temperatura absoluta $[\mathrm{K}]$ e pressão $[\mathrm{KPa}]$

$(F / A)=$ razão ar-combustível $[\mathrm{Kg} / \mathrm{Kg}]$

$r_{c}=$ razão de compressão [adm.]

$\mathbf{M}=$ peso molecular do fluido de trabalho no ciclo [adm]

$\gamma=$ razão dos calores específicos do fluido de trabalho no ciclo [adm] 
$\mathbf{x}_{\mathbf{r}}=$ fração de gases residuais $[\mathrm{adm}]$

$\mathrm{R}_{(\mathrm{a}, \mathrm{o})}=$ Constante do ar nas condições atmosféricas padrão [J/Kmol]

$\mathrm{V}_{\mathrm{d}}=$ cilindrada do motor $\left[\mathrm{m}^{3}\right]$

$\mathrm{V}_{1}=$ volume do cilindro $\left[\mathrm{m}^{3}\right]$

$\therefore:=1, \quad$ ermo entre \{\} da eq. (5.5) é igual a 1.

5.6.2 - Efeitos da Razão Ar-Combustivel, Fase e Composição do Combustível.

?. vtores de ignição por centelha, a presença do combustível gasoso e sor agua no coletor de admissão reduz substancialmente a pressão parcial do ar na mistura. Para misturas de ar $(a)$, vapor d'água $(w)$, gases ou vapor de combustível $(f)$, a pressão no duto de admissão $\left(p_{i}\right)$ pode ser expressa da seguinte forma:

$$
p_{i}=p_{a i}+p_{f i}+p_{w i}
$$

que aplicando a lei dos gases ideal resulta:

$$
\frac{p_{a, i}}{p_{i}}=\left[1+\left(\frac{\dot{m}_{f}}{\dot{m}_{a}}\right)\left(\frac{M_{a}}{M_{f}}\right)+\left(\frac{\dot{m}_{w}}{\dot{m}_{a}}\right)\left(\frac{M_{a}}{M_{w}}\right)\right]^{-1}
$$


O fator de correção do vapor d'água é usualmente pequeno, cerca de 0,03 . A Figura 5.3, extraída do REYWOOD (1988), mostra a influência da densidade do combustivel na pressão parcial do ar no coletor de admissão.

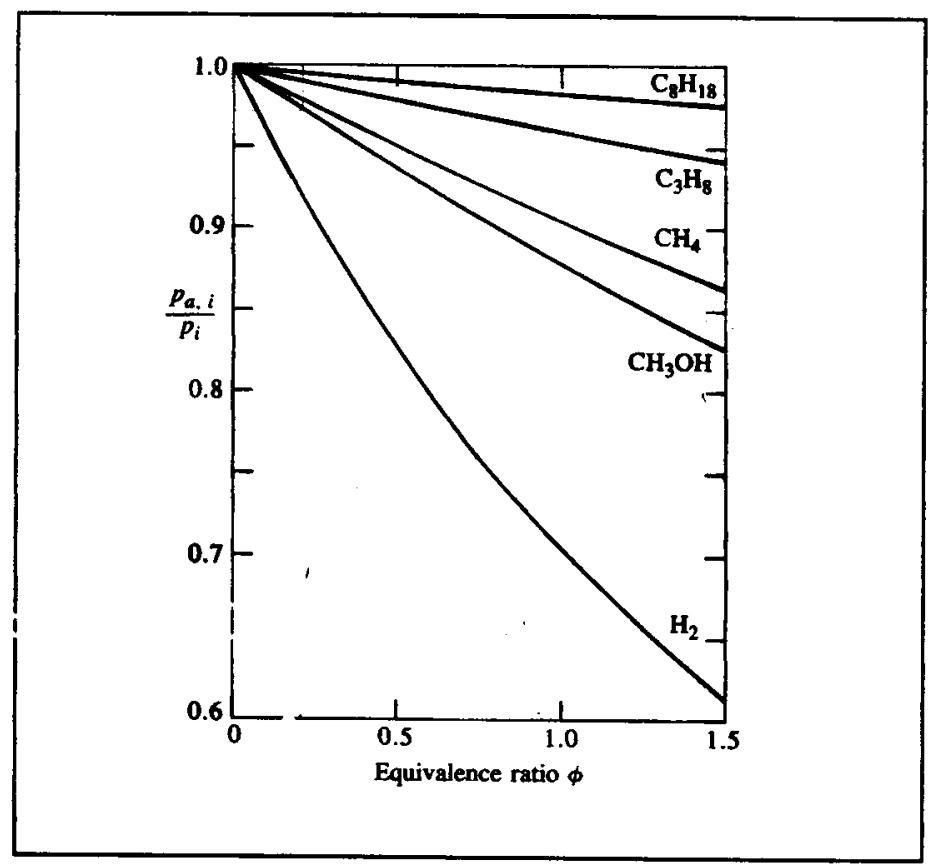

FIGURA 5.3 - Efeito o Vapor do Combustivel na Pressão Parcial do Ar. Razão da Pressão de Admissão do $\operatorname{Ar}\left(P_{a, i}\right)$ para Pressão de Admissão da Mistura $\left(P_{i}\right)$ Versus Razão Equivalente $(\phi)$ para Vapor de Iso-octano, propano, metano, vapor de metanol e hidrogênio.

Como se pode observar na figura anterior, para os combustiveis convencionais como a gasolina $\left(\mathrm{C}_{8} \mathrm{H}_{18}\right)$, esse efeito promovido pelo vapor do combustível, independentemente da razão ar-combustivel, é pequeno. Entretanto, para os combustíveis gasosos e metanol vaporizado, a eficiência volumétrica é substancialmente reduzida pela pressão parcial do combustivel na mistura. 


\subsection{3 - Efeitos da Fração do Combustivel Vaporizado, do Calor de Vaporização e da Transferência de Calor.}

Para escoamento a pressão constante de um fluido bi-fásico evaporando e com transferência de calor, a equação da energia em regime permanente é:

$$
\left[\dot{m}_{a} h_{a}+\left(1-x_{e}\right) \dot{m}_{f} h_{f, L}+x_{e} \dot{m}_{f} h_{f, V}\right]_{A}=\dot{Q}+\left(\dot{m}_{a} h_{a}+\dot{m}_{f} h_{f, L}\right)_{B}
$$

onde, $\left(\mathrm{x}_{\mathrm{e}}\right)=$ fração de massa evaporada e os sub-índices significam: $(a)=$ propriedades do ar; $(f)=$ propriedades do combustível; $(V)=$ vapor; $(\mathrm{L})=$ líquido; $(A)=$ depois da evaporação; $(B)=$ antes da evaporação. Aproximando-se a variação de entalpia necífica (h) de cada componente da mistura por $C_{p} \Lambda T$, e com a entalpia de vapuitzação $h_{f, V}-h_{L V}=h_{f, L V}$, da eq. (5.8) vem:

$$
T_{A}-T_{B}=\frac{\left(\dot{Q} / \dot{m}_{a}\right)-x_{e}(F / A) h_{f, L V}}{c_{p, a}+(F / A) c_{f, L}}
$$

uma vez que $c_{f, L} \sim 2 c_{p, a}$ o último termo do denominador pode ser desprezado.

Se não existe transferência de calor entre o meio (paredes do coletor) e a mistura ar-combustivel, a temperatura da mistura necessariamente diminue por efeito da evaporação do combustível. Para completa evaporação do isooctano com $\phi=1.0$, $\mathrm{T}_{\mathrm{A}}-\mathrm{T}_{\mathrm{B}}=-19^{\circ} \mathrm{C}$. Para o metanol nas mesmas condições, $\mathrm{T}_{\mathrm{A}}-\mathrm{T}_{\mathrm{B}}=-128^{\circ} \mathrm{C} . \mathrm{Na}$ prática, este processo não é adiabático, sempre ocorre troca de calor entre as paredes do coletor e a mistura e o combustível não é completamente vaporizado antes de entrar no cilindro. Dados experimentais mostram que o decréscimo na temperatura do 
ar que acompanha a vaporização do combustível líquido é mais significativo do que a redução da pressão parcial do ar devido ao aumento da quantidade de combustível vaporizado: para a mesma taxa de aquecimento, a eficiência volumétrica com a vaporização do combustível é aumentada em poucos pontos percentuais.

A eq. (5.5) da eficiência volumétrica mostra que os efeitos na variação da temperatura ao entrar no cilindro é dado pelo fator $\left(\mathrm{T}_{\mathrm{a} . \mathrm{o}} / \mathrm{T}_{\mathrm{i}}\right)$. Dados experimentais revelam que uma dependência da eficiência volumétrica com a raiz quadrada da razão de temperatura em um motor real. Essa dependência com a raiz quadrada é um padrão assumido nos testes de motores para redução dos dados.

\subsection{4 - Efeitos da Razão de Compressão e Razão da Pressão de Admissão e Exaustão.}

Segundo REYWOOD (1988) a fração do volume de gás residual retido no cilindro do motor varia em função da relação entre a pressão de admissão e a pressão de exaustão $\left(\mathrm{p}_{\mathrm{e}} / \mathrm{p}_{\mathrm{i}}\right)$ e também da razão de compressão $\left(\mathrm{r}_{\mathrm{c}}\right)$. Com o aumento do volume gases residuais a eficiência volumétrica diminue. Estes efeitos na eficiência volumétrica do ciclo ideal são expressos pelo termo entre \{\} da eq. (5.5). A Figura 5.4, reproduzida do REYWOOD (1988), mostra esses efeitos para $\gamma=1,3$. 


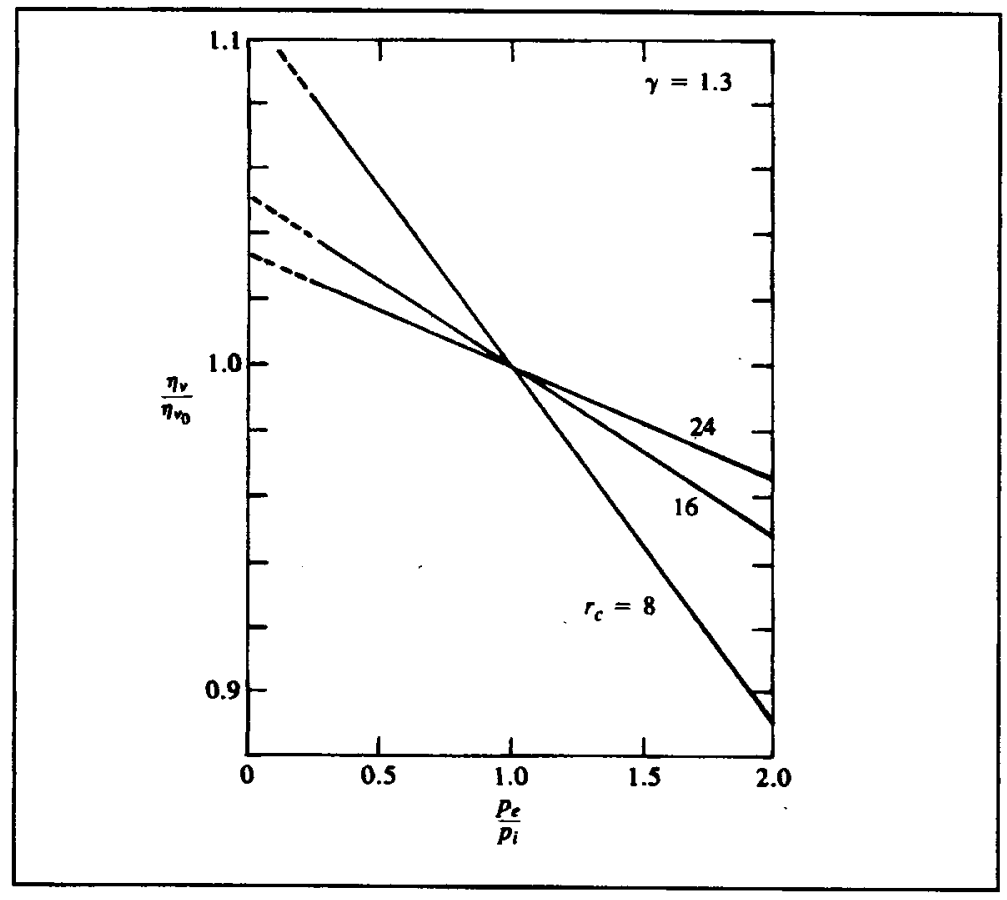

FIGURA 5.4 - Efeito da Razão de Pressões de Admissão e Escape na Eficiência Volumétrica do Cicln Irisal.

\section{7 - EFEITOS DINÂMICOS E QUASI-ESTÁTICOS COMBINADOS}

REYWOOD (1988) descreve que no escoamento transiente de um gás real através de tubos, câmaras, válvulas etc, estão presentes forças de pressão, de inércia e de fricção. A importância relativa dessas forças depende da velocidade do gás e do tamanho e forma das áreas de passagem e suas junções. Ambos'os efeitos, dinâmicos e quasi-estáticos são significativos. Muito embora os efeitos das variações na velocidade, projeto do coletores de admissão e exaustão e das válvulas estejam 
interrelacionados, alguns dos fenômenos que afetam a eficiência volumétrica podem ser identificados isoladamente, são eles:
a) Perdas por fricção
b) Efeito RAM (pressão de impacto)
c) Escoamento Reverso na admissão
d) Tuning

\subsection{1 - Perdas por Fricção}

Durante o curso de admissão, devido ao atrito em cada um dos elementos que compõem o sistema de admissão, a pressão no cilindro $\left(P_{c}\right)$ é menor que a pressão atmosférica por uma quantidade que depende da raiz quadrada da velocidade. Essa queda de pressão total é a soma da queda de pressão em cada elemento do sistema de admissão: filtro de ar, carburador e borboleta do acelerador, coletor, porta e válvula de admissão. A maior perda de carga ocorre justamente na porta e janela de admissão, com as demais perdas representando uma pequena porcentagem da perda total. Como resultado, a perda de pressão total no cilindro, quando ele se move com velocidade máxima durante o curso de admissão é cerca de $10 \%$ a $20 \%$ menor que a pressão atmosférica. A perda de carga em cada componente do sistema de admissão e de exaustão pode ser expressa a partir da equação de Bernoulli por: 


$$
\Delta p_{j}=\xi_{j} \rho v_{j}^{2}
$$

onde $(\xi)$ é o coeficiente de resistência para cada componente e depende de sua geometria e velocidade local. Assumindo que o escoamento é permanente, $\left(v_{\mathrm{j}}\right)$ está relacionado como a velocidade média do pistão $\left(S_{p}\right)$ por:

$$
v_{j} A_{j}=\bar{S}_{p} A_{p}
$$

onde $\left(A_{j}\right) e\left(A_{p}\right)$ corresponde respectivamente a menor área de escoamento no elemento e a área do pistão. Logo, a perda de pressão total devido a friç̧ão é:

$$
-p=\Sigma \Delta p_{j}=\sum \xi_{j} \rho \bar{S}_{p}^{2} \sum \xi_{j}\left(\frac{A_{p}}{A_{j}}\right)^{2}
$$

A eq. (5.14) irdica a importância de grandes áreas de escoamento dos elementos do sistema de admissão para redução das perdas por friç̧ão e a dependência destas perdas com a velocidade do motor.

A Figura 5.5 mostra as perdas de pressão devido as restrições dos elementos que compõem o sistema de admissão de um motor veicular operando em regime de plena carga.

As perdas de pressão no sistema de exaustão são principalmente devido às restrições na válvula e tubulação de exaustão, aonde os niveis de pressão são maiores que a pressão atmosférica. 


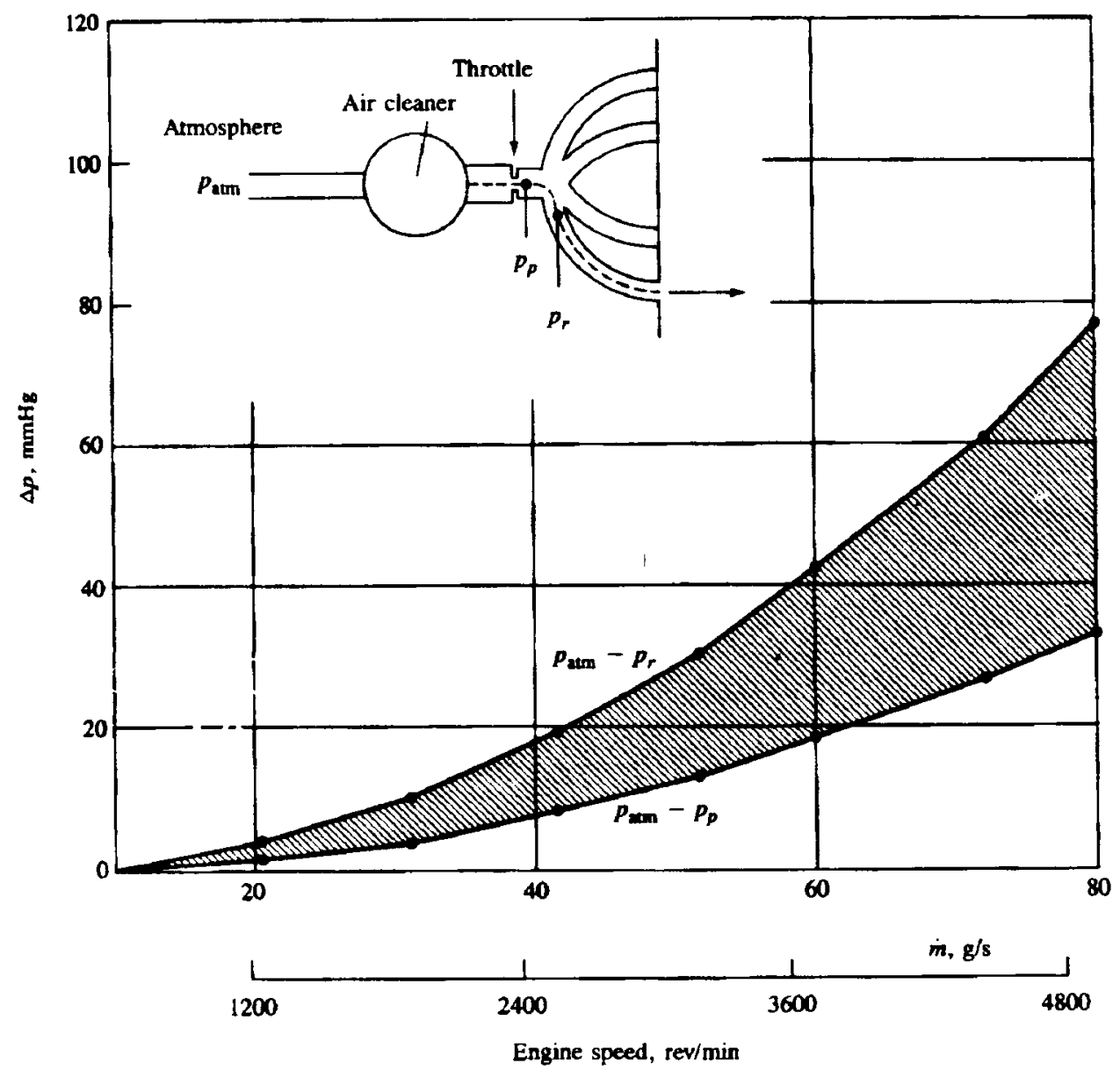

FIGURA 5.5 - Perdas de pressão no sistema de admissão de um motor de ignição por centelha em regime permanente, curso $=89 \mathrm{~mm}$ e $\cdot$ diâmetro $=$ $84 \mathrm{~mm}$.

A Figura 5.6 ilustra as perdas de pressão no coletor de exaustão em função do coletor de admissão (o qual varia inversamente com a carga) e velocidade para um motor de ignição por centelha veicular de quatro cilindros. Em altas velocidades e cargas, a pressão no coletor de exaustão é maior que a pressão atmosférica. 


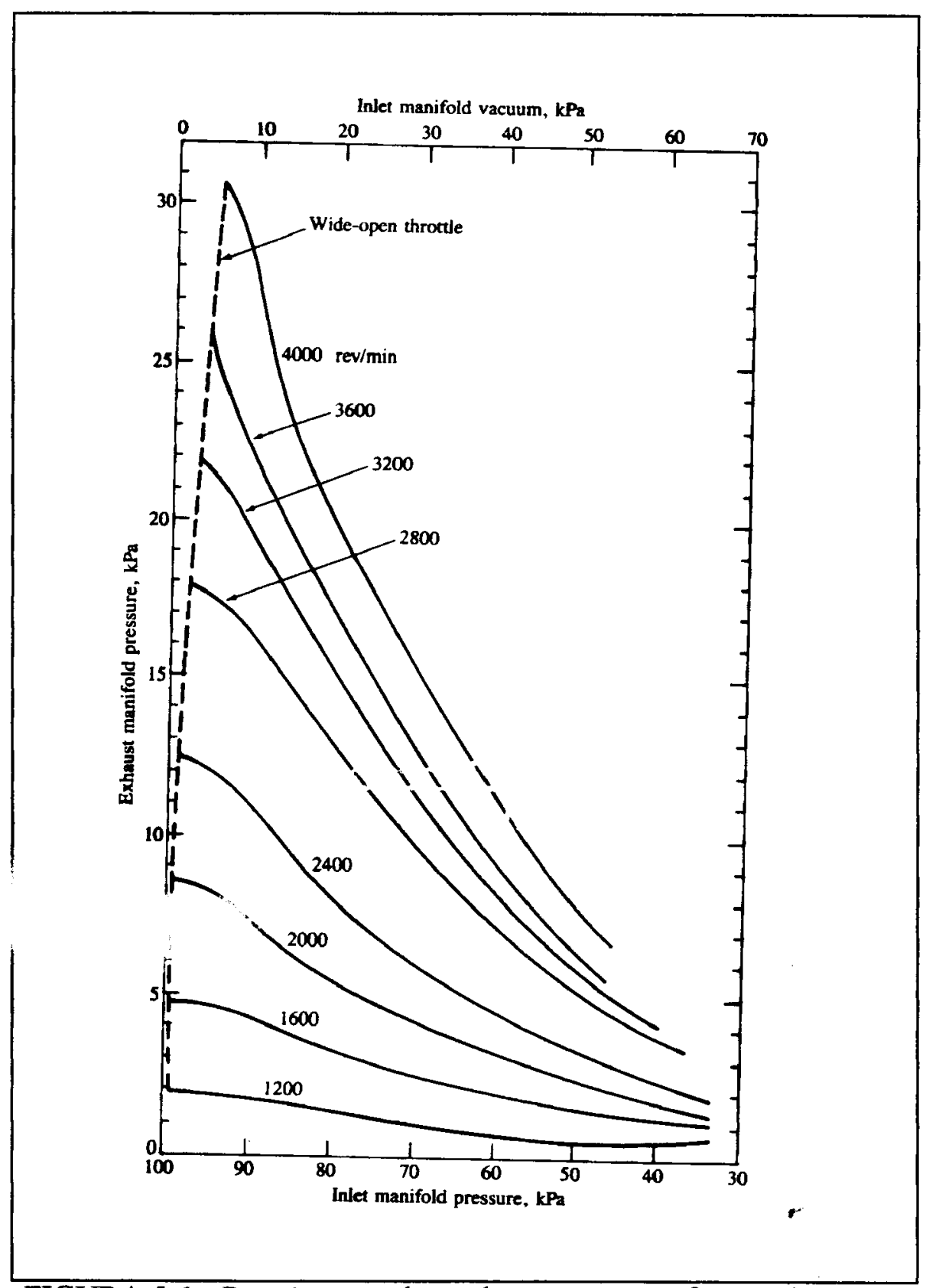

FIGURA 5.6 - Pressão no coletor de exaustão em função da carga e velocidade de um motor de ignição por centelha de 4 cilindros. 
Testes realizados em regime permanente, revelam que para todas as velocidades do motor operando em regime de plena carga, as perdas de pressão no escoamento da carga fresca são proporcionais ao quadrado da velocidade.

\subsection{2 - Efeito RAM}

A pressão no coletor de admissão varia durante o processo de admissão em cada cilindro devido às variações da velocidade do pistão, da área de abertura das válvulas e dos efeitos do escoamento não-permanente no fluído de trabalho, decorrentes dessas variações geométricas.

A massa de ar no cilindro e por conseguinte a eficiência volumétrica é muito dependente do nível de pressão na área de passagem da válvula, especialmente durante o pequeno período que antecede o fechamento da válvula.

Em altas velocidades, a inércia do gás no sistema de admissão quando a válvula de admissão está fechando aumenta a pressão na porta e continua o processo de enchimento mesmo após o pistão atingir o PMI e iniciar o curso de compressão.

Este efeito é majorado com o aumento da velocidade do motor. A válvula de admissão fecha totalmente cerca de 40 a $60^{\circ}$ depois do PMI, em parte para tomar vantagem deste efeito RAM. 


\subsection{3 - Fluxo Reverso na Admissão}

O atraso no fechamento da válvula de admissão para se obter, principalmente altas velocidades, um melhor enchimento decorrentes do efeito RAM, pode gerar também um escoamento reverso da carga fresca admitida no cilindro quando a pressão do cilindro cresce devido ao movimento do pistão durante a fase final do curso de admissão. Este fenômeno é maior para baixas velocidades do motor.

\subsection{4 -Tuning}

O escoamento pulsante resultante do processo de exaustão de cada cilindro, promove ondas de pressão em todo o sistema de exaustão. Estas ondas de pressão, na velocidade do som, propagam-se movimentando (perturbando) os gases de exaustão. A interação destas ondas de pressão com o coletor e toda tubulação de exaustão causa ondas de pressão que são refletidas de encontro aos cilindros do motor. Nos motores mulcilindricos, estas ondas de pressão de cada cilindro, transmitidas e refletidas no sistema de exaustão, podem interagir com os outros cilindros do motor. Os efeitos resultantes destas interações podem melhorar ou inibir o processo de renovação da carga. Quando há uma melhora no processo de carregamento, por redução das pressões a jusante (depois) da válvula de exaustão, no final do processo de exaustão, o sistema de exaustão é chamado de "tuning". 
De forma análoga, as variações no fluxo de admissão da carga fresca para o cilindro, causam ondas de expansão no coletor de admissão. Estas ondas de expansão podem interagir com o coletor e toda tubulação de admissão, resultando em ondas de pressão que são refletidas e transmitidas de encontro aos cilindros do motor. Se o tempo destas ondas é sincronizado de forma apropriada, o efeito resultante será um aumento da pressão de admissão, no final do curso de indução. Este acréscimo na pressão de admissão, deverá induzir uma maior massa de ar para o cilindro do motor. Assim, o sistema de admissão é denominado "tuning".

A Figura 5.7 mostra a variação da pressão nos coletores de admissão e de exaustão de um motor veicular operando em regime de plena carga. A amplitude dessas flutuações cresce substancialmente, com o aumento da rotação do motor. $\mathrm{O}$ fenômeno é complexo e a magnitudi cessas flutuações de pressão cresce com o aumento da velocidade do motor.

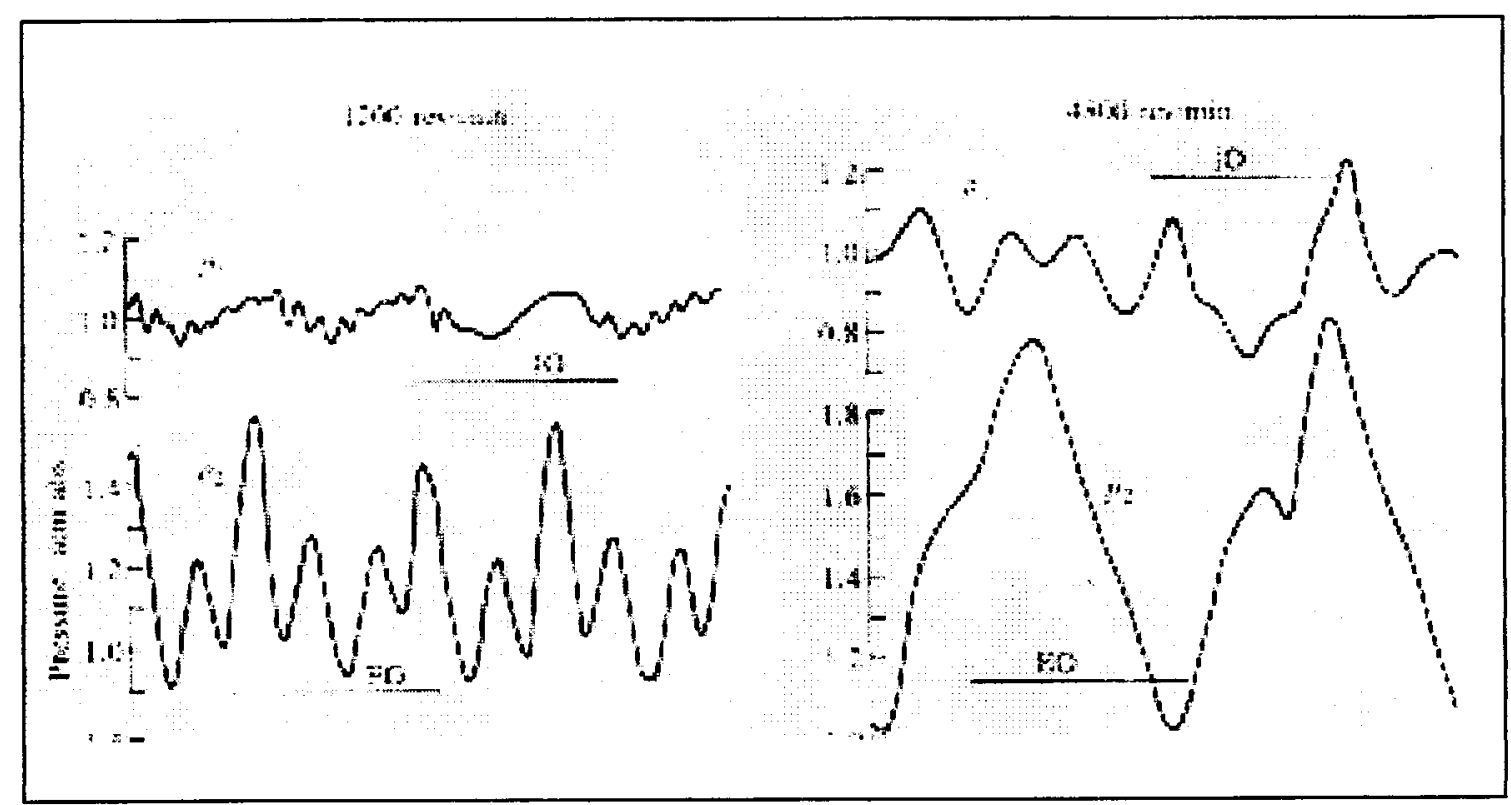

FIGURA 5.7 - Pressão instantânea no coletor de admissão e exaustão de um motor de ignição por centelha de 4 tempos. $P_{1}=$ coletor de admissão; $\mathrm{P}_{2}=$ coletor de exaustão. 


\subsection{5 - Efeitos da Velocidade, Área da Válvula e do Tempo}

De acordo com REYWOOD (1988), os efeitos do escoamento na eficiência volumétrica dependem da velocidade da mistura aspirada no coletor de admissão, na porta e válvulas. As velocidades local, para regime permanente são iguais à vazão volumétrica dividido pela área da seção transversal. Desde que as dimensões do sistema de admissão e válvulas estão em escala conveniente com o diâmetro do cilindro, as velocidades no sistema de admissão são proporcionais as velocidades do pistão. Logo, as eficiências volumétricas em função da velocidade, para diferentes motores, podem ser comparadas nas mesmas velocidades média do pịtão.

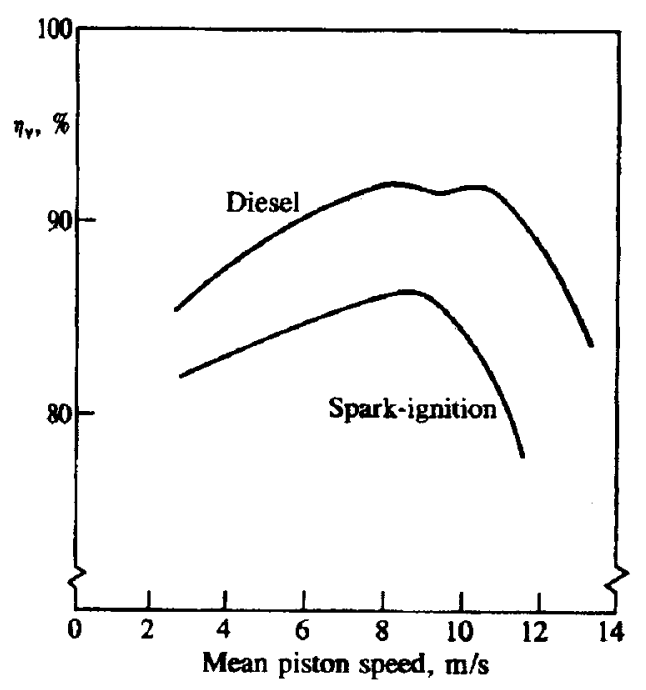

FIGURA 5.8 - Eficiência Volumétrica Versus Velocidade Média do Pistão de um Motor de 04 Cilindros com Injeção Indireta de Diesel e um Motor de 06 Cilindros de Ignição por Centelha. 
A Figura 5.8, extraida do REYWOOD (1988), mostra curvas típicas da eficiência volumétrica versus velocidade média do pistão para um motor Diesel de quatro cilindros de injeção indireta e de um motor de ignição por centelha de seis cilindros, em regime de plena carga.

Segundo ele, as eficiências volumétricas dos motores de ignição por centelha são menores que as dos motores Diesel devido as perdas de carga no carburador e borboleta do acelerador, aquecimento do coletor de admissão, presença de vapor de combustivel e uma maior fração de gases residuais no coletor de admissão. Os modernos motores de ignição por centelha apresentam rendimento volumétrico da ordem de 80 a $90 \%$.

Atravós du Figura 5.9, também extraida do REYWOOD (1988), é gossivei explicar a curva de tendência para eficiência volumétrica em função da velocidade angular do motor.

Esta figura apresenta de forma esquemática, os efeitos de diversos fenômenos, descritos nas seções anteriores deste capitulo, sobre a eficiência volumétrica em função da velocidade do motor. Os efeitos independentes da velocidade tais como pressão do vapor do combustível reduzem $\left(\eta_{v}\right)$ a menos de $100 \%$ (curva A). Os efeitos das trocas de calor no coletor de admissão e no cilindro é representado pela queda da curva A para curva B. Este efeito é mais acentuado nas baixas rotações quando o tempo de residência do gás é maior. As perdas por fricção do escoamento crescem proporcionalmente com o quadrado da velocidade, e tal queda é mostrada da curva B para curva C. Em altas velocidades, o escoamento para o cilindro durante as últimas partes do processo de admissão começa a ser obstruido, 
pelo fechamento da válvula de admissão (escoamento blocado) Quando isso ocorre, a eficiência volumétrica diminui suavemente com o aumento da velocidade angular do motor ( curvas de C para D). O efeito RAM de indução, em altas velocidades, aumenta da curva D para curva $E$. O fechamento tardio da válvula de admissão para aumentar o carregamento em altas rotações, resulta também em um decréscimo de $\eta_{v}$ em baixas rotações devido ao "Backflow" ( curvas C e D para curva F). Finalmente, o efeito "tuning" da admissão e/ou descarga, pode aumentar o eficiência volumétrica de uma quantidade substancial em todo o intervalo de rotação do motor (curva de $\mathrm{F}$ para G).

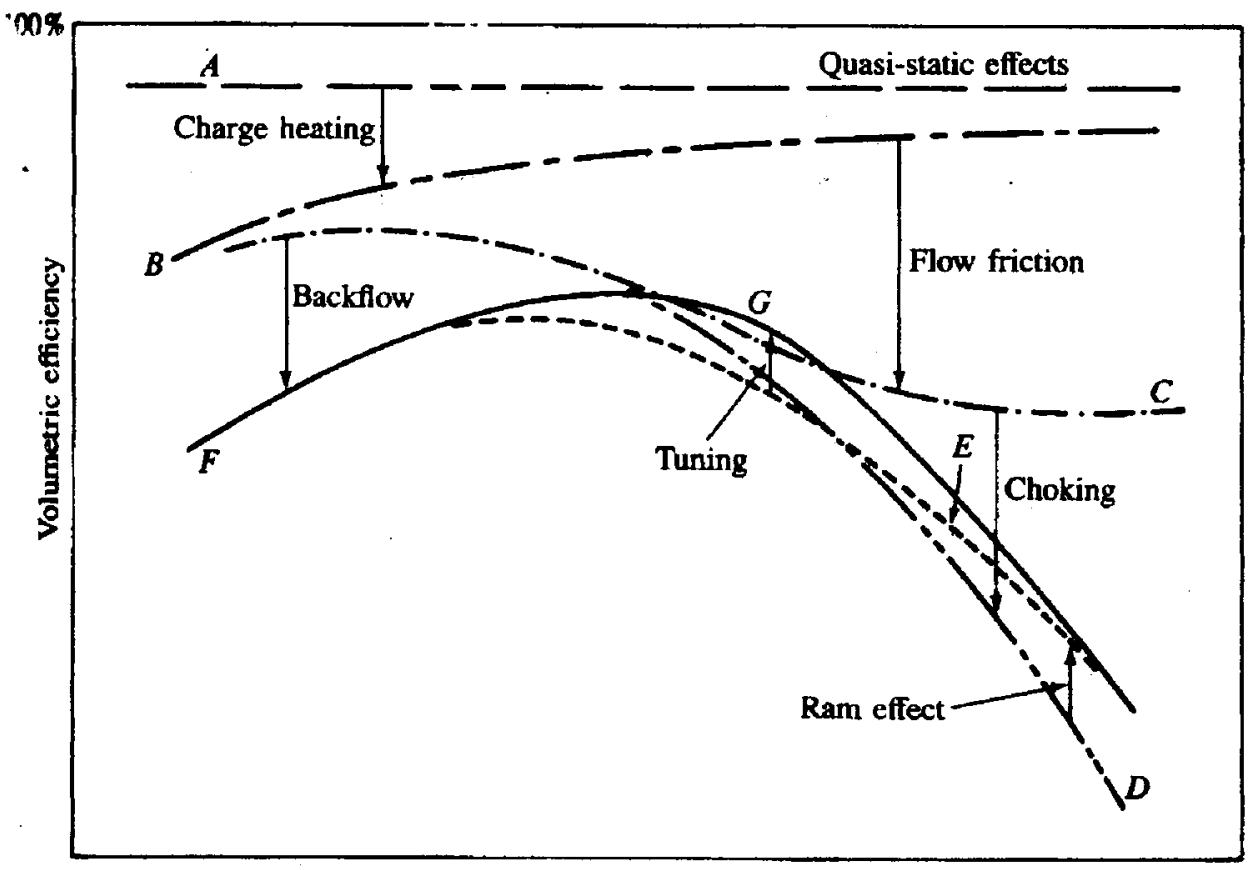

Mean piston speed

FIGURA 5.9 - Efeitos de diferentes fenômenos de escoamento do ar na eficiência Volumétrica do motor em função da velocidade. A linha sólida é a curva final de $\eta_{\mathrm{v}}$ versus a rotação. 


\section{8 - EFICIÊNCIA VOLUMÉTRICA REDUZIDA AS CONDIÇÕES PADRÃo}

Assim como a potência e o torque do motor, a capacidade de aspiração de ar dos motores de combustão interna, isto é, o rendimento volumétrico, também é influenciada pela pressão, temperatura e umidade do ar ambiente.

Fatores de correção são utilizados para ajustar os valores medidos de rendimento volumétrico às condições padrão, permitindo estabelecer uma base mais acurada de comparação entre os motores. REYWOOD (1988)

As condições padrão ${ }^{4}$ estabelecidas pela norma AFNT-5484 (Associação Brasileira de Normas Técnicas) para correção são:

- temperatura: $298 \mathrm{~K}$

- pressão do ar seco: $99 \mathrm{kPa}$

- pressão do vapor d'água: $1 \mathrm{kPa}$

Os fatores de correção são estabelecidos com base na eq. (5.15) para o escoamento unidimensional, permanente e compressivel através de um orificio ou restrição ao fluxo de área efetiva $\left(\mathrm{A}_{\mathrm{E}}\right)$.

\footnotetext{
${ }^{4}$ REYWOOD (1988), apresenta valores ligeiramente diferentes da norma ABNT-5484. Para ele, os valores padrão utilizados para correção são: temperatura $=302,4 \mathrm{~K}$; pressão do ar $\operatorname{seco}=98,21 \mathrm{kPa}$; pressão do vapor dágua $=1,286 \mathrm{kPa}$.
} 


$$
\dot{m}=\frac{A_{E} p_{o}}{\sqrt{R T_{o}}}\left\{\frac{2 \gamma}{\gamma-1}\left[\left(\frac{p}{p_{o}}\right)^{\gamma / 2}-\left(\frac{p}{p_{o}}\right)^{(\gamma+1) / \gamma}\right]\right\}^{1 / 2}
$$

na dedução da eq. (5.1), assumiu-se que o fluido é um gás perfeito com (R) e ( $\gamma=$ $C_{p} / C_{v}$ ) constantes; ( $p_{o}$ e $T_{o}$ ) são as pressões e temperaturas à montante da restrição e (p) é a pressão na garganta da restrição

Se, em um motor operando em regime de plena carga, a relação de pressão $\left(\mathrm{p} / \mathrm{p}_{\mathrm{o}}\right)$ é considerada constante, a vazão de ar seco $\left(\dot{m}_{\mathrm{a}}\right)$ varia da seguinte forma: REYWOOD (1988)

$$
\dot{m}_{a} \propto \frac{p_{o}}{\sqrt{T_{o}}}
$$

A eficiência volumétrica é proporcional a $\left(\dot{m}_{\mathrm{a}} / \rho_{\mathrm{a}}\right)$, visto que $\left(\rho_{\mathrm{a}}\right)$ é proporcionai a $(\mathrm{p} / \mathrm{T})$. Lai o fator de correção para eficiência volumétrica é:

$$
F_{c}^{\prime}=\frac{\eta_{v, s}}{\eta_{v, m}}=\left(\frac{T_{s}}{T_{m}}\right)^{1 / 2}
$$

onde:

$\eta_{\mathrm{v}, \mathrm{s}}=$ rendimento volumétrico padrão, $[\mathrm{adm}] ;$

$\eta_{\mathrm{v}, \mathrm{m}}=$ rendimento volumétrico medido, [adm];

$\mathbf{T}_{\mathrm{m}}=$ temperatura ambiente medida, $[\mathrm{K}]$;

$T_{\mathbf{s}}=$ temperatura ambiente padrão, $[K]$. 


\section{9 - A RELAÇÃO ENTRE O RENDIMENTO VOLUMÉTRICO E OUTROS PARÂMETROS DE DESEMPENHO DO MOTOR.}

A importância do rendimento volumétrico torna-se mais evidente quando outros parâmetros de desempenho do motor tais como potência, torque e pressão média indicada, são expressos em termos deste parâmetro. Partindo-se das seguintes equações básicas:

$$
\begin{aligned}
& P=\frac{2 \pi \cdot N T}{1000} \\
& \text { pem }=\frac{1000 \cdot P \cdot n_{r}}{V_{d} \cdot N} \\
& \eta_{c c}=\frac{P}{\dot{m}_{f} \cdot Q_{H V}} \\
& (F / A)=\frac{\dot{m}_{f}}{\dot{m}_{a}} \\
& \eta_{v}=\frac{2 \dot{m}^{\prime}}{\rho_{a, i} \cdot V_{d} \cdot N}
\end{aligned}
$$

onde: $\mathrm{P}=$ potência $[\mathrm{KW}] ; \mathrm{N}=$ rotação do motor $[\mathrm{rps}] ; \mathrm{T}=$ torque $[\mathrm{N} . \mathrm{m}] ;$ pem=pressão média efetiva $[\mathrm{kPa}] ; \mathrm{V}_{\mathrm{d}}=$ cilindrada $\left[\mathrm{dm}^{3}\right] ; \mathrm{n}_{\mathrm{r}}=$ número de revoluções da árvore de manivelas por ciclo; $\eta_{\mathrm{cc}}=$ eficiência de conversão do combustivel $[\mathrm{adm}] ; \dot{m}_{f}=$ vazão mássica de combustível por ciclo $[\mathrm{g} / \mathrm{h}] ; \quad Q_{H V}=$ poder calorifico superior $[\mathrm{g} / \mathrm{kw} . \mathrm{h}$ ]; 
$(F / A)=$ razão combustível-ar $[\operatorname{adm}]$. As seguintes relações podem ser desenvolvidas, para um motor de ignição por centelha de 4 tempos:

- Para Potência (P):

$$
P=\frac{\eta_{f} \eta_{v} \cdot N \cdot V_{d} \cdot Q_{H V} \cdot \rho_{a, i} \cdot(F / A)}{2}
$$

- Para o Torque (T):

$$
T=\frac{\eta_{f} \eta_{v} \cdot V_{d} \cdot Q_{H V} \rho_{a, j} \cdot(F / A)}{4 . \pi}
$$

- Para Pressão Média Efetiva (mep):

$$
m e p=\eta_{f} \eta_{v} \cdot Q_{H V} \rho_{a, i} .(F / A)
$$

5.20 e 5.21) revelam a importância direta no desempenho de um wivior de ignição por centelha do:

1. Alto rendimento volumétrico $\left(\eta_{\mathrm{v}}\right)$;

2. Da alta eficiência de conversão do combustível $\left(\eta_{\mathrm{cc}}\right)$;

3. Do aumentado da densidade do $\operatorname{Ar}$ de admissão $\left(\rho_{\mathrm{a}, \mathrm{i}}\right)$

4. Da razão ar-combustivel (F/A) que pode ser queimada no motor. 


\section{CAPÍTULO 06 - MATERIAIS E MÉTODOS}

Este capítulo tem como finalidade descrever os procedimentos experimentais e os equipamentos utilizados nesta tese, visando o desenvolvimento de um sistema de injeção direta de gás natural a baixas pressões e levantamento de dados para avaliação do desempenho do motor de testes, funcionando com o sistema de injeção proposto.

\section{1 - PROCEDIMENTOS EXPERIMENTAIS}

O sistema de injeção direta de gás natural, desenvolvido no presente trabalho, foi incorporado e testado em um motor monocilíndrico de 4 tempos e aspiração natural. $O$ diagrama da Figura 6.1 apresenta esquematicamente o motor de testes instalado no dinamômetro com os principais dispositivos utilizados para controle e medição dos parâmetros de interesse. 


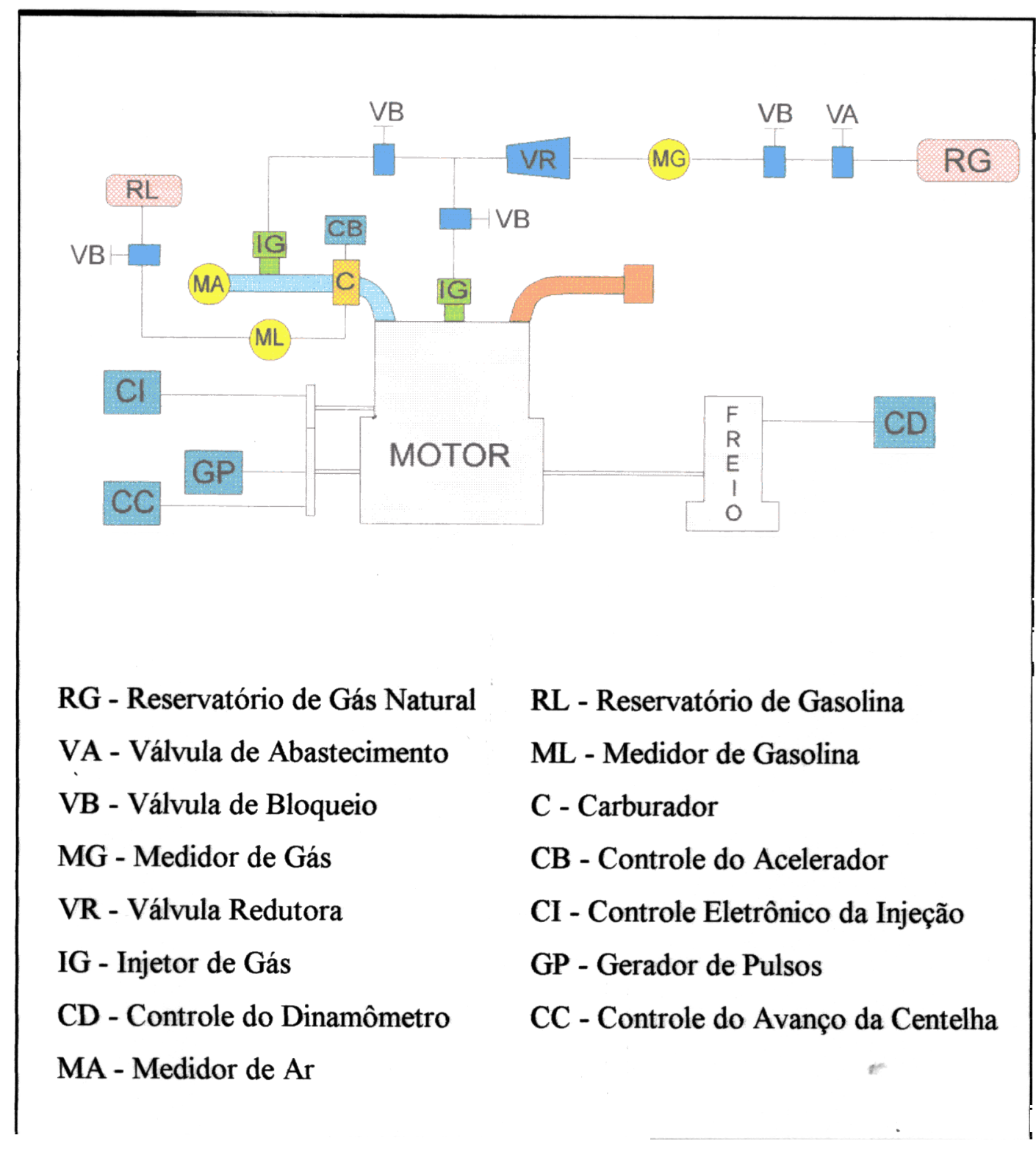

FIGURA 6.1 - Diagrama Esquemático de Montagem dos Equipamentos de Controle do Motor de Testes no Dinamômetro.

neste esquema, a seguinte simbologia é adotada 
RG - reservatórios de armazenamento de gás natural, composto de 03 cilindros com capacidade de aproximadamente $30 \mathrm{Kg}$ de gás natural na pressão de $220 \mathrm{Kgf} / \mathrm{cm}^{2}$;

VA - válvula de abastecimento de gás natural modelo RODAGÁS;

VB- válvula de bloqueio de combustivel líquido ou gasoso (modelo RODAGÁS) para o motor;

MG - sistema gravimétrico de medição do consumo de gás natural projetado e construído para mensurar o consumo de gás natural do motor de testes, composto de um pórtico com contrapesos, balança digital cap. $03 \mathrm{~kg}$, sensibilidade de 1 grama e 01 cilindro de gás com capacidade de aproximadamente $5 \mathrm{Kg}$ de gás natural na pressão de $220 \mathrm{Kgf} / \mathrm{cm}^{2}$;

VR - válvula pneumática reguladora de pressão, da WHITE MARTINS modelo R-80 (utilizada em equipamento de solda oxi-acetileno para controle do fluxo de oxigênio) adaptada para controlar a pressão de injeção do gás, a montante do conjunto de injeção direta de gás natural;

IG - Conjunto de injeção de gás natural, projetado e construído para injetar o gás natural, a baixas pressões, nas diversas condições de teste do motor. O conjunto de injeção direta de gás natural é composto de um porta injetor de gás contendo uma válvula solenóide dosadora de combustível em série com uma válvula de retenção e um circuito de refrigeração; 
CD - Sistema de Controle do Dinamômetro composto de uma unidade eletrônica que controla a carga (freio) aplicado ao eixo e a rotação do motor;

MA - sistema de medição do consumo de ar do motor composto, por um tambor de equalização e amortecimento das pulsações do fluxo de ar, com orificio calibrado de 19 mm de diâmetro, termopar e manômetro inclinado de coluna de água graduado de 0 a 30 $\mathrm{mm} \mathrm{H}_{2} \mathrm{O}$;

RL - reservatório de combustível líquido (gasolina), capacidade 5 litros;

ML - sistema volumétrico de medição do consumo de combustível líquido (gasolina) com bureta graduada em mililitros e cronômetro digital com resolução de centésimos de segundos.

C - Carburador tipo venturi fixo de fluxo ascendente monocorpo;

CB - sistema de controle da posição da borboleta do acelerador com acionamento manual através de manete de passo micrométrico;

CI - sistema eletrônico de controle da injeção de gás metano, composto de 01 sensor indutivo sincronizado com o comando de válvulas para captar o sinal de freqüência e referência do motor e 01 módulo eletrônico de controle da injeção (MEC), projetado e desenvolvido para adequar a dosagem de gás natural aos vários regimes de operação do motor de testes; 
GP - Gerador óptico de pulsos modelo AVL, acoplado ao eixo motor para medição de ângulos na árvore de manivelas e com sinal de saída conectado a um oscilcscópio marca Tecktronic de $100 \mathrm{mHz}$ com 8 canais, utilizado para monitoramento do avanço de centelha, da largura do pulso de injeção, ponto de injeção e pressão indicada (sensor AVL piezoeléctrico instalado no cabeçote do motor)

CC - Sistema de controle da ignição transistorizada com mecanismo de avanço da centelha, desenvolvido para otimizar a ignição da mistura ar-combustivel para todas as condições de operação do motor de testes;

Antes dos ensaios dinamométricos do motor propriamente dito, todos os componentes nrojetados e fabricados ou mesmo adaptados visando a injeção de gás natural nc interior do cilindro do motor, foram submetidos a testes de avaliação, com intuito de assegurar o seu perfeito estado de funcionamento, definir limites de operação e/ou corrigir eventuais falhas.

Uma vez definido os objetivos a serem alcançados, o desenvolvimento da parte experimental iniciou-se com a escolha do motor de testes. Os critérios de seleção adotados foram: facilidade de instalação do conjunto de injeção direta no cabeçote do motor e sensores, baixo consumo de combustível, disponibilidade ou custo do motor, taxa de compressão. Na oportunidade, outros critérios também relevantes e que deveriam ser levados em consideração como o tipo de câmara de combustão e sistema de ignição, nivel de vibração foram negligenciados, resultando em grandes dificuldades para o desenvolvimento da pesquisa. Com base nos critérios estabelecidos, foi selecionado e 
adquirido um motor ciclo Otto de $11 \mathrm{HP}$ da marca Briggs Stration, monocilindro e refrigerado a ar e cujas especificações técnicas estão apresentadas na Tabela 6.1.

TABELA 6.1 - Especificações do Motor.

\begin{tabular}{|l|l|}
\hline Marca & Briggs Stration \\
\hline Modelo & $11 \mathrm{Hp}$ \\
\hline Aplicação & Industrial \\
\hline Sistema de aspiração & Natural \\
\hline Sistema de partida & Retrátil e elétrico \\
\hline Cíclo de funcionamento & 4 tempos \\
\hline Sistema de combustão & Ignição por centelha \\
\hline Sistema de ignị̧ãc & iviagrıtu - àanço fixo \\
\hline Sistema de alimentação & Carburação de gasolina \\
\hline Número de cilindros & 01 \\
\hline Cilindrada & $400 \mathrm{~cm}$ \\
\hline Taxa de compressão & $8,3: 1$ \\
\hline Curso do pistão & 66,7 mm \\
\hline Diâmetro do cilindro & $87,3 \mathrm{~mm}$ \\
\hline Sistema de refrigeração & Ar \\
\hline Válvula de admissão abre a & $55^{\circ}$ antes do PMS \\
\hline Válvula de admissão fecha a & $20^{\circ}$ depois do PMI \\
\hline Válvula de exaustão abre a & $77^{\circ}$ antes do PMI \\
\hline Válvula de exaustão fecha a & $20^{\circ}$ depois do PMS \\
\hline
\end{tabular}


O primeiro passo para realização deste trabalho consistiu em definir as características do sistema de injeção direta, quanto ao sistema de controle, componentes e materiais utilizados. $\mathrm{Na}$ Tabela 6.2 é apresentado um resumo os testes realizados em componentes e sistemas, destacando os objetivos e resultados obtidos.

TABELA 6.2 - Testes de Avaliação dos Componentes.

\begin{tabular}{|c|c|c|}
\hline COMPONENTES & TESTE REALIZADO & CONCLUSỖES \\
\hline CID & $\begin{array}{l}\text { Estanqueidade (método da } \\
\text { bolha de sabão) com ar } \\
\text { comprimido até } 10 \text { bar. }\end{array}$ & $\begin{array}{l}\text { não } \quad \text { se } \\
\text { vazamentos. }\end{array}$ \\
\hline VEIC & $\begin{array}{l}\text { Acionamento bobina solenóide } \\
\text { direto na bateria com ar } \\
\text { comprimido até } 10 \text { bar. }\end{array}$ & funcionou normal. \\
\hline VEIC & $\begin{array}{l}\text { Motor MONZA } 1.8 \text { SPI com } \\
\text { injeção de GLP a } 4 \text { bar, com } \\
75 \% \text { do curso do acelerador. }\end{array}$ & $\begin{array}{l}\text { O toraue obser rado } \\
\text { fo: surca de } 50 \% \text { do } \\
\text { torq le máximo }\end{array}$ \\
\hline Refrigeração do CID. & $\begin{array}{l}\text { Ensaio de plena carga no } \\
\text { motor de testes }(11 \mathrm{Hp}) .\end{array}$ & $\begin{array}{l}\text { Temperatura da água } \\
\text { de retorno } \sim 35^{\circ} \mathrm{C} \text {. }\end{array}$ \\
\hline MEC & $\begin{array}{l}\text { Acionamento da VEIC no } \\
\text { coletor de admissão do motor, } \\
\text { a montante do acelerador. }\end{array}$ & $\begin{array}{l}\text { Permitiu regulagem } \\
\text { de mistura em todas } \\
\text { as cargas e rpm. } \\
\end{array}$ \\
\hline MEC & $\begin{array}{l}\text { Acionamento da VEIC no } \\
\text { cabeçote do motor. CID } \\
\text { próximo a vela de ignição. } \\
\text { (posição 1) }\end{array}$ & $\begin{array}{l}\text { ruídos elétricos da } \\
\text { ignição interferiam } \\
\text { no controle da } \\
\text { injeção. }\end{array}$ \\
\hline $\begin{array}{l}\text { MEC com filtro capacitivo } \\
\text { e cabo de vela supressivo. }\end{array}$ & $\begin{array}{l}\text { idem. com o CID mais afastado } \\
\text { da vela de ignição. (posição 2) }\end{array}$ & $\begin{array}{l}\text { Os ruídos elétricos } \\
\text { foram eliminados. }\end{array}$ \\
\hline Ignição transistorizada & Potência da centelha & $\begin{array}{l}10 \text { a } 20 \% \text { superior ao } \\
\text { sistema de magneto } \\
\text { em todas as RPM. }\end{array}$ \\
\hline $\begin{array}{l}\text { Mecanismo de regulagem } \\
\text { do Avanço da centelha }\end{array}$ & $\begin{array}{l}\begin{array}{l}\text { regulagem do avanço da } \\
\text { centelha. }\end{array} \\
\end{array}$ & satisfatório. \\
\hline
\end{tabular}


Como o motor em estudo era novo e por não ter sido operado anteriormente, antes mesmo das adaptações para operação com injeção de gás natural o motor foi submetido inicialmente a fase de amaciamento funcionando com o combustível original (gasolina), conforme as recomendações do fabricante.

As principais modificações do motor foram feitas nos sistemas de alimentação e ignição. O sistema de ignição original, por magneto, foi retirado e substituído por um sistema de ignição transistorizada com regulagem mecânica do avanço da centelha.

Foi desenvolvido, um sistema de injeção com gerenciamento eletrônico para injeção de gás natural a baixas pressões na câmara de combustão do motor de testes. A dosagem do gás, para as diversas condições de carga e velocidade angular do motor, foi fıita por meio de uma válvula elétrica injetora de combustível $V E I C$ inserida no cabeçote do motor. Mantendo-se a pressão da linha de alimentação do gás constante, através de uma válvula redutora, a quantidade de gás natural injetado no cilindro era ajustada eletronicamente variando-se o tempo de abertura da válvula de dosagem de combustível VEIC.

Um dinamômetro corrente de Foucaut foi utilizado para frenagem do motor. Sensores de temperatura e pressão foram inseridos no motor em pontos estratégicos, que adicionados a medidas de torque, rotação, consumo de ar e combustivel, avanço de centelha, tempo e ponto de injeção permitiram o monitoramento dos ensaios. 
Tal monitoramento foi realizado por um sistema de aquisição de dados computadorizado que mantinha em meio magnético de armazenamento um histórico do ensaio.

Para medição do consumo de ar aspirado, foi acoplado ao coletor de admissão do motor de testes, um sistema de tambor para equalização e amortecimento das pulsações do fluxo de ar, com placa de orificio calibrado e manômetro diferencial.

A Tabela 6.3, fornecida pela PETROBRÁS DISTRIBUIDORA, mostra as principais especificações do gás natural utilizado nos testes realizados.

TABELÁ 6.3 - Especificacões dì GNC

\begin{tabular}{|l|l|}
\hline Metano & 90,20 \\
\hline Etano & 6,96 \\
\hline Propano & 1,69 \\
\hline Butano & 0,23 \\
\hline Nitrogenio & 0,55 \\
\hline Dióxido de Carbono & 0,26 \\
\hline Outros & 0,11 \\
\hline PCS (Kcal/Nm ${ }^{3}$ ) & 9,342 \\
\hline Densidade Relativa & 0,616 \\
\hline Peso Molecular & 17,83 \\
\hline
\end{tabular}

Obs: a $20^{\circ} \mathrm{C}$ e $1,033 \mathrm{Kg} / \mathrm{cm}^{2}$, composição vol. (\%) 
Foi ainda desenvolvido no laboratório um sistema de medição do tipo gravimétrico, para medição do consumo de gás natural do motor de testes. $\mathrm{O}$ sistema gravimétrico foi inserido na linha de alta pressão de GNC, entre os reservatórios de armazenamento de gás e a válvula redutora de pressão e apresenta resolução de 1 grama.

O motor de testes foi submetido a ensaios de plena carga, em regime permanente, nas rotações de 2000 a 4000 com incrementos de 200 RPM. Inicialmente, o motor foi ensaiado com carburação de gasolina. Numa segunda etapa, foram realizados os ensaios de plena carga com injeção de gás natural no coletor de admissão e finalmente, numa terceira etapa, foram feitos ensaios de plena carga com injeção de gás natural diretamente no cilindro do motor. Nos ensaios de injeção direta, a pressão de injeção foi limitada na

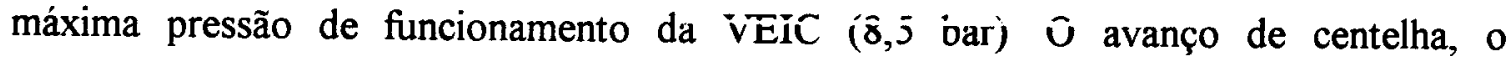
sincronismo da injeção e a dosagem do combustível foram ajustados em cada rotação de ensaio para a condição de melhor torque observado (MTB). Todos os ensaios dinamométricos, foram realizados com base nos procedimentos estabelecidos na norma ABNT 5484. 


\section{2 - DESCRIÇÃO DOS EQUIPAMENTOS E INSTALAÇÕES}

Para realização dos ensaios dinamométricos e obtenção das curvas características de desempenho do motor funcionando com injeção direta de gás metano, foram desenvolvidos e/ou incorporados ao banco dinamométrico, além da instrumentação e equipamentos já existentes, os seguintes equipamentos:

- Conjunto de injeção direta de gás natural;

- Módulo eletrônico de controle da injeção de gás natural;

- Sisterna de armazenamento e medição do consumo de gás natural;

- Sistema de ignição transistorizada;

- Sistema proteção e acoplamento motor-dinamômetro;

- Sistema de aquisição de dados computadorizado.

A seguir, são apresentados detalhes construtivos e de funcionamento do conjunto de injeção direta de gás natural, do módulo eletrônico de gerenciamento da injeção de gás natural, da ignição transistorizada adaptada ao motor de testes e também do sistema gravimétrico de medição do consumo de gás natural do motor de testes, desenvolvidos no presente trabalho. 


\subsection{1 - Sistema de Injeção Direta de Gás Natural}

A estratégia de injeção direta de gás natural, proposta no presente trabalho, caracteriza-se por utilizar uma válvula elétrica injetora de combustível $V E I C$ em série com uma válvula de retenção, para injeção de gás natural, a baixas pressões, diretamente na câmara de combustão de um motor ciclo Otto.

Dentre as vantagens do sistema de injeção direta de gás natural a baixas pressões, proposto no presente trabalho, destacam-se a maior utilização da carga útil de gas natural armazenada nos cilindros de alta pressão e o baixo custo do conjunto de injeção direta, uma yez que pode-se utilizar nari dosagem do gás natural no cilindro do motor, simplesmente uma váliula elétrica injetora de combustivel VEIC de um sistema convencional de injeção indireta.

No sistema de injeção direta proposto, a quantidade de combustivel injetado por ciclo é controlada ajustando-se o tempo de abertura da válvula solenóide $V E I C$, para uma pressão de injeção constante. A cada ciclo motor, tem-se um único período de injeção, sendo o tempo de injeção e o início da injeção ajustados eletronicamente. O combustível é injetado no cilindro de modo sincronizado com o curso de admissão.

A Figura 6.2 apresenta esquematicamente o sistema de controle e monitoramento da injeção direta de gás natural direta de gás natural que, juntamente com o diagrama da Figura 6.1 permitem descrever o princípio de funcionamento deste sistema de injeção. 


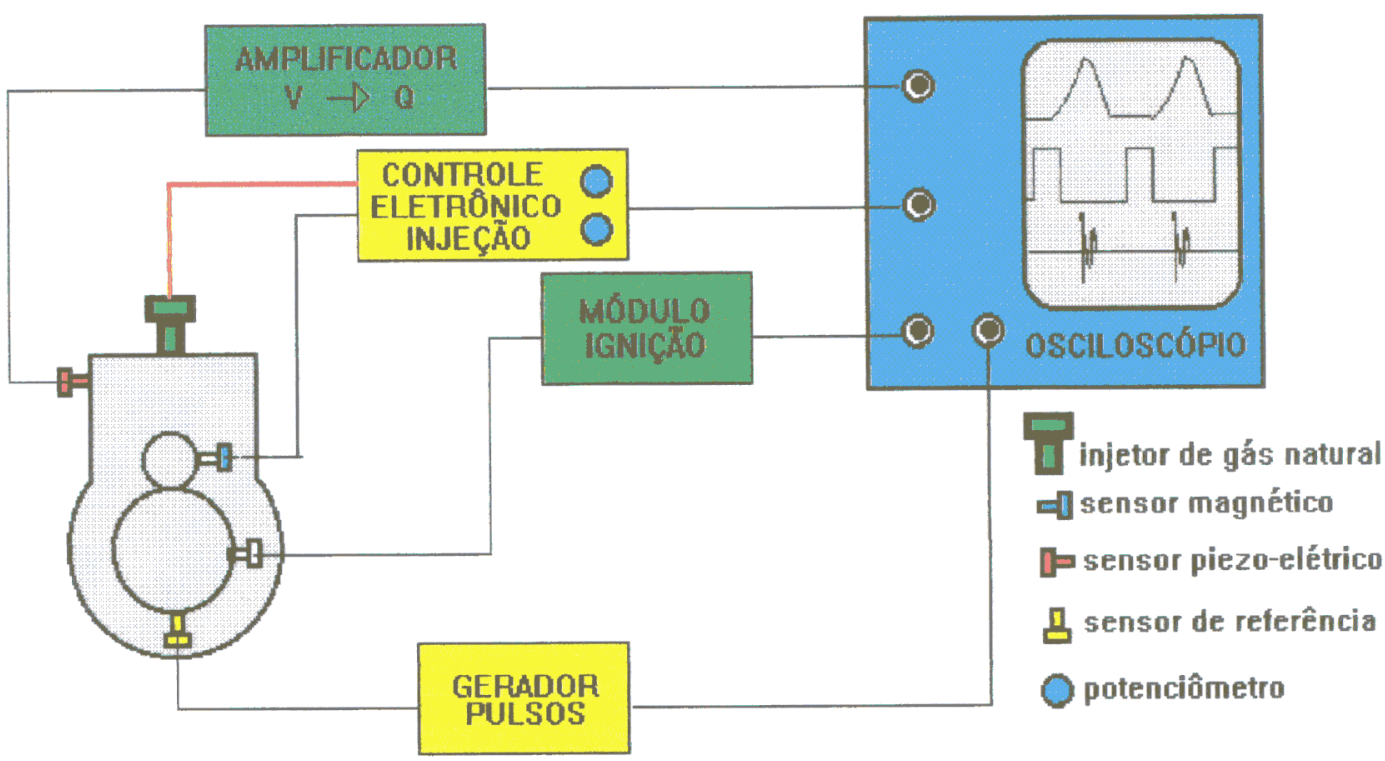

FIGURA 6.2 - Diagrama esquemático do sistema de controle e monitoramento da injeção direta de gás natural, do monitoramento da ignição e pressão indicada do motor de testes.

Na Figura 6.1, Estando a válvula de bloqueio (VB) aberta, o gás, proveniente dos cilindros de alta pressão (até 220 bar), passa através da válvula redutora de pressão (VR), aonde sua pressão é reduzida para pressão de injeção (aproximadamente 8,5 bar), seguindo até o conjunto de injeção direta de gás natural (CID), instalado no cabeçote do motor. Com o motor em funcionamento, o módulo eletrônico de controle da injeção (MEC) da Figura 6.2, recebe do sensor magnético (SM), instalado no eixo de comando de válvulas do motor, o sinal de freqüência ( $\mathrm{rpm}$ ) e referência do ciclo. O sensor magnético inserido no comando de válvulas, foi sincronizado inicialmente com o ponto 
morto superior no final do periodo de admissão. Posteriormente, para estabelecer o regime de plena em altas rotações do motor, houve a necessidade de um novo ponto de sincronismo, desta feita, com o ponto morto inferior do curso de admissão. Atuando-se nos potenciômetros do (MEC), ajusta-se, respectivamente, o tempo de injeção e o início da injeção. Os 02 potenciômetros do (MEC) foram selecionados para possibilitar, respectivamente, um ajuste preciso da quantidade de combustivel injetada e uma ampla variação do início da injeção, garantindo o funcionamento do motor desde a condição de marcha lenta até a condição de plena carga em todas as rotações de ensaios do motor.

A Figura 6.3, mostra um diagrama do conjunto de injeção direta de gás natural, com indicação dos principais componentes. O gás natural chega ao (CID) com uma pressão de 8,5 bar. A quantidade de gás que flui através da váivuia sưiciiưiủe ('viéc) ć controlada eletronicamente pelo (MEC). Quando a pressão do gás a montante da válvula de retenção é suficiente para mantê-la aberta, o gás flui naturalmente para a câmara de combustão do motor. Caso contrário, a válvula de retenção fecha cessando o periodo de injeção de gás. $\mathrm{O}$ circuito de refrigeração é de fundamental importância e tem como finalidade retirar o excesso de calor, garantindo a integridade dos componentes (anéis de vedação, VEIC, válvula de retenção) e evitando variações dimensionais que poderiam acarretar um funcionamento irregular destes elementos.

A válvula solenóide (1) de dosagem do combustível da Figura 6.3, é do tipo normalmente fechada. Quando energizada, o campo magnético estabelecido pela bobina do solenóide vence a ação da mola interna, deslocando verticalmente sua haste da sede 
cerca de $0,1 \mathrm{~mm}$ e permitindo assim, a passagem do gás, sob pressão, através do espaço anular entre a haste e sua sede, até a antecâmara, a montante da válvula de retenção.

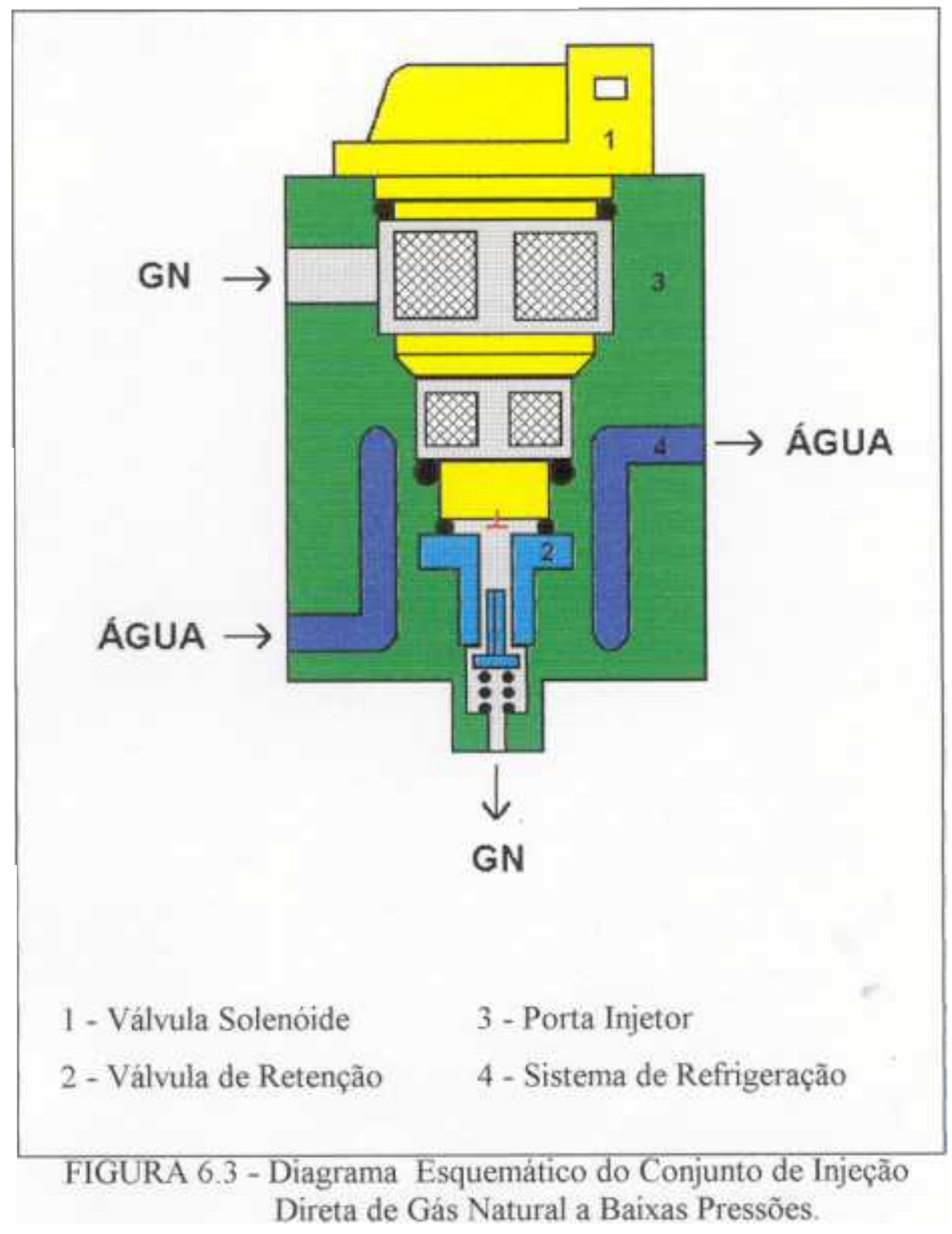


O diagrama de corpo livre da válvula de retenção do conjunto de injeção direta, mostrado na Figura 6.4, permite estabelecer com detalhes, o período de injeção de gás natural na câmara de combustão do motor de testes.

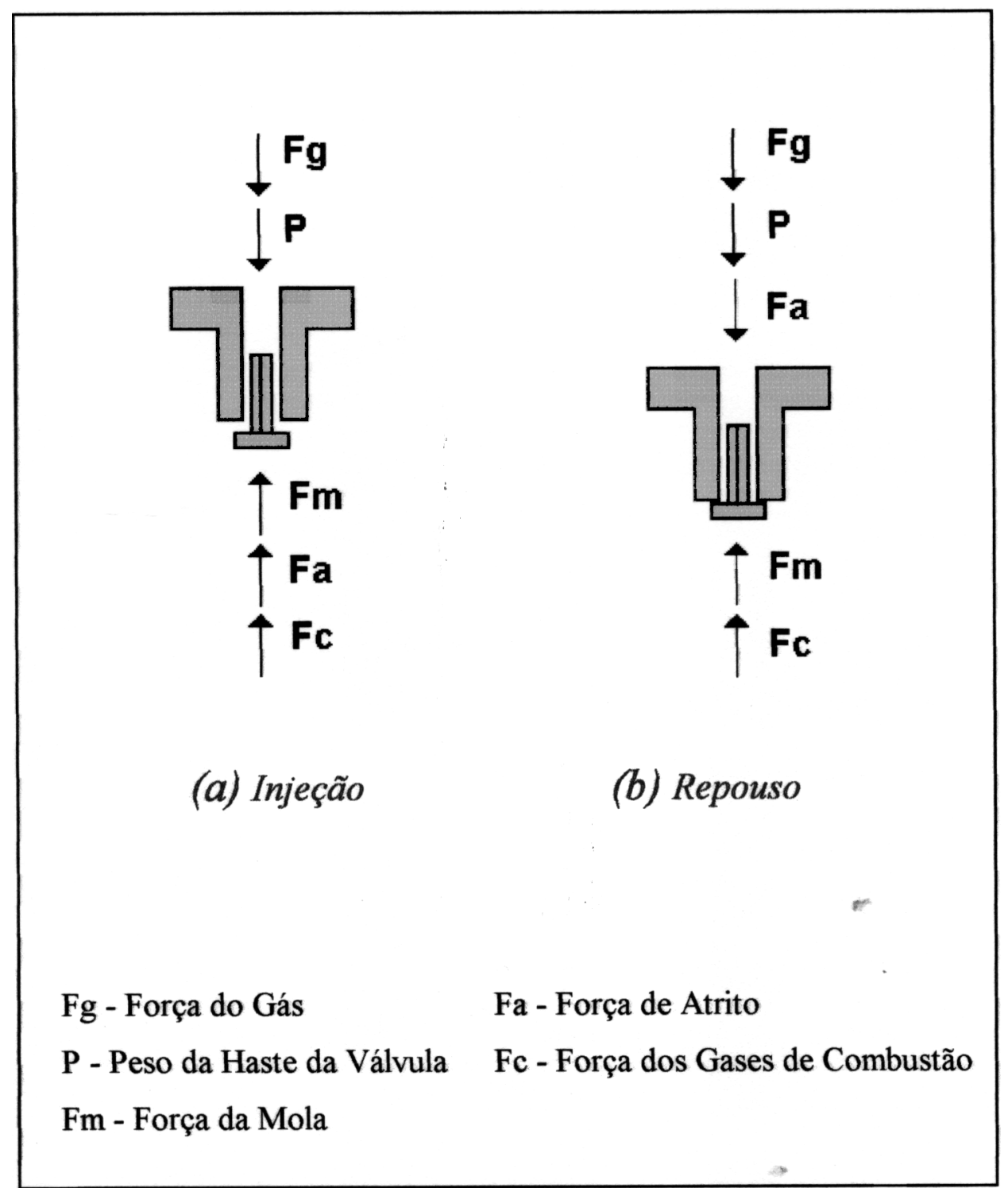

FIGURA 6.4 - Diagrama de Corpo Livre da Válvula de Retenção do Conjunto de Injeção Direta de Gás Natural. 
Quando a força do gás $\left(\mathrm{F}_{\mathrm{g}}\right)$ na antecâmara supera a ação da mola $\left(\mathrm{F}_{\mathrm{m}}\right)$, a força de pressão $\left(\mathrm{F}_{\mathrm{c}}\right)$ da câmara de combustão a e as forças de friç̧ão $\left(\mathrm{F}_{\mathrm{a}}\right)$ ali existentes, a válvula de retenção abre e o gás flui para o interior do cilindro do motor. Quando, a força de pressão da câmara de combustão mais a ação da mola vence a forca do gás da antecâmara o peso (P) do sistema mola-válvula de retenção, a válvula de retenção fecha, cessando o escoamento de gás natural para o cilindro do motor e, ao mesmo tempo, evitando que os gases queimados na câmara de combustão do motor, penetrem na antecâmara a jusante da válvula solenóide (VEIC).

\subsection{2 - Módulo Eletrônico de Controle da Injeção}

A Figura 6.5, apresenta o diagrama elétrico da unidade de gerenciamento eletrônico desenvolvida para controlar a injeção de gás natural no motor de testes. Este circuito elétrico consiste de dois estágios, o primeiro tem como finalidade fazer o sincronismo da injeção de gás natural, isto é, definir o melhor momento para iniciar o período de injeção. O segundo estágio do circuito, tem como função definir a quantidade de combustível a ser liberado em cada periodo de injeção de gás natural. o sincronismo e a dosagem do combustível foram realizados atuando-se nos dois potenciômetros do circuito. 


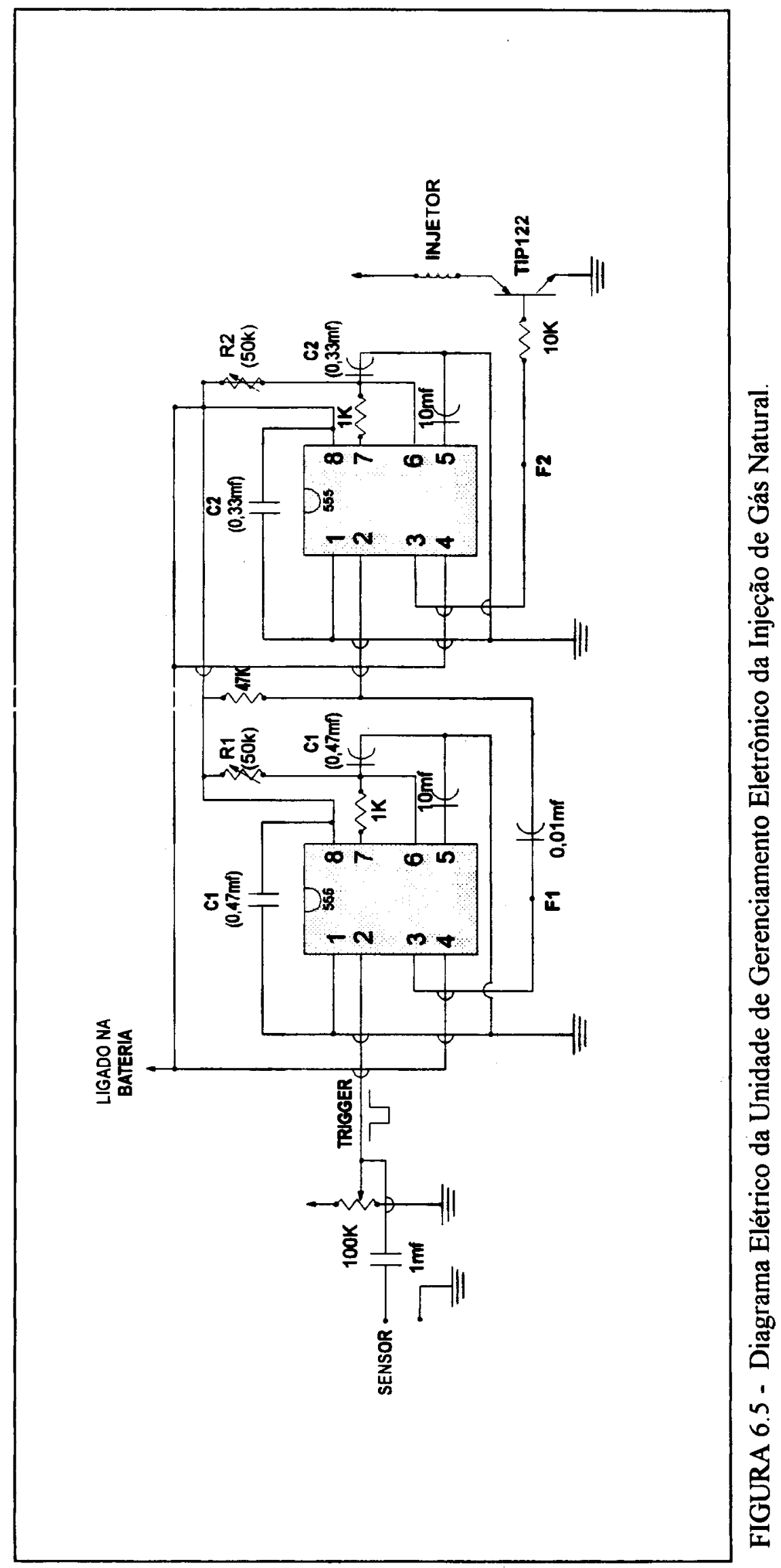




\subsection{3 - Sistema de Ignição Transistorizada}

Nos ensaios de otimização de um motor ciclo Otto, se faz necessário ajustar, além da razão ar-combustível, o avanço de centelha para propiciar uma queima mais eficiente do combustível, com maior economia de combustível e menor índice de emissão de poluentes na descarga do motor.

O sistema original de ignição por magneto do motor de testes, não apresentava dispositivos de avanço de centelha, impossibilitando portanto, a otimização do avanço de centelha para operação com injeçã s de gás natural. Inicialmente, foram propostos e construídos dois mecanismos para variar o avanço da centelha mediante o deslocamento angular do magneto sobre o volante do motor.

No primeiro protótipo, a base de fixação do magneto, em alumínio (material não ferroso), era presa a um disco que deslizava em outro disco guia fixado na carcaça do motor. No segundo protótipo, um mancal foi acoplado à arvore de manivelas do motor, através de dois rolamentos cônicos. Uma aste com suporte de alumínio fixa no mancal, prendia o magneto. Tais mecanismos, não atenderam as exigências de controle, desregulando com freqüência em virtude da grande força de atração do magneto e da vibração transmitida pelo funcionamento motor, principalmente em baixas rotações e cargas elevadas. 
Por estas razões, o sistema original de ignição por magneto do motor de testes, foi retirado e substituído por um sistema de ignição transistorizada de um veículo de série. Na adaptação da ignição transistorizada, um rotor em forma de setor circular, com meia volta de comprimento, fixado ao volante do motor, juntamente com um sensor indutivo incorporado ao mancal do protótipo 2 , descrito anteriormente, comandavam a ignição.

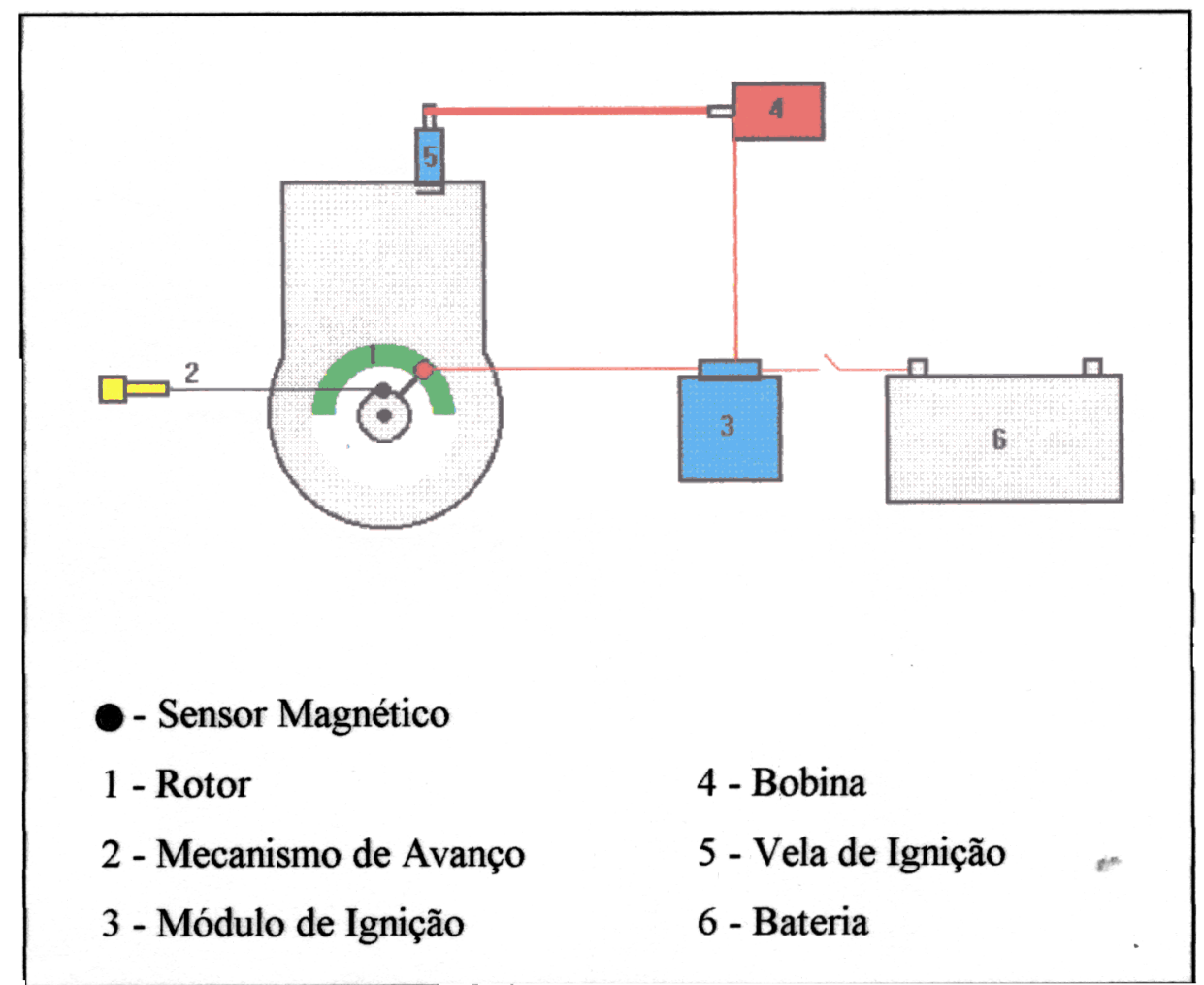

FIGURA 6.6 - Diagrama Esquemático do Sistema de Ignição transistorizada com Mecanismo de Controle do Avanço da Centelha

A Figura 6.6, apresenta o sistema de ignição transistorizada adaptado ao motor de testes. Estando o motor em funcionamento, a face (a) do rotor (1) ao passar a frente 
do sensor magnético (2) liga o circuito primário da bobina de ignição (3) que permanece energizada até que a face (b) do rotor passe a frente do sensor magnético. Neste instante, o circuito primário é interrompido bruscamente induzindo no secundário da bobina de ignição uma alta tensão que promove o centelhamento na vela de ignição (5).

Uma manete de passo micrométrico (6) articulada no suporte do sensor magnético, permite ao operador regular à distância (da sala de controle do dinamômetro), o avanço da centelha.

\subsection{4 - Sistema Gravimétrico de Medição do Consumo de Gás Natural}

Nos Ensaios de motores de combustão interna, a determinação do consumo de combustivel é fundamental para avaliação do desempenho e capacidade de transformação da energia química do combustível em energia mecânica disponivel no eixo. $\mathrm{O}$ consumo de combustível pode ser medido em base volumétrica ou mássica. Para combustiveis gasosos, a medição direta de massa é mais recomendada e, em muitos casos, de fácil calibração e operação.

A Figura 6.7, permite descrever o princípio de funcionamento do sistema de medição gravimétrico desenvolvido neste trabalho, para determinação da massa de gás natural consumida pelo motor de testes. 


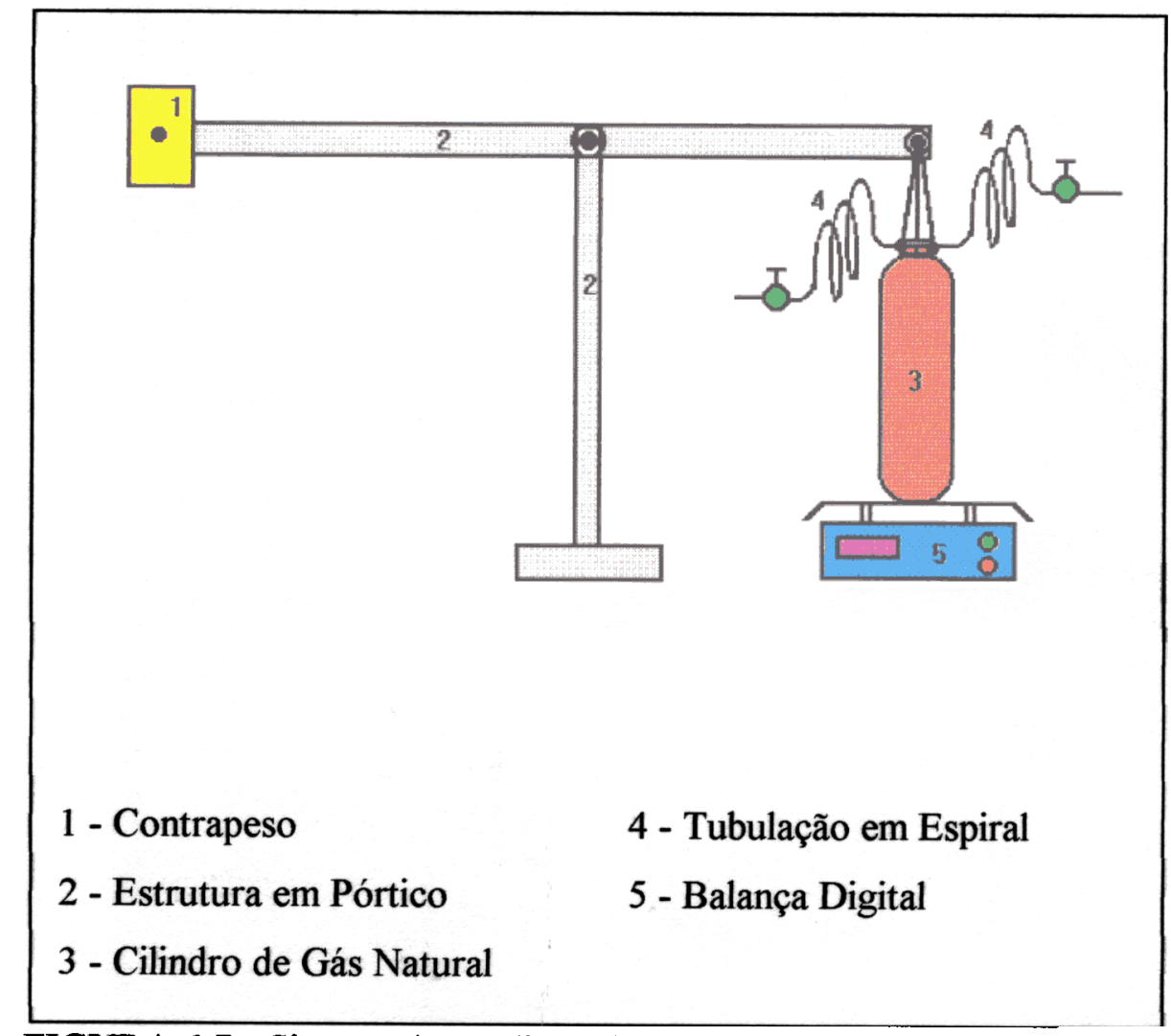

FIGURA 6.7 - Sistema de Medição do Consumo de Gás Natural

O sistema de medição gravimétrico foi inserido na linha de alta pressão de gás natural, entre os reservatórios de armazenamento e a válvula redutora de pressão. Os contrapesos eliminam o peso morto do cilindro de medição. Estando a válvula de bloqueio (VB) fechada, a massa de gás consumida pelo motor, em um determinado intervalo de tempo, é medida com uma balança digital. Os trechos de tubulação em espiral confere ao cilindro de medição movimento livre ( quase sem nenhuma restrição) na direção vertical, de modo que pequenas variações de massa no cilindro de medição podem ser detectadas com uma balança de precisão. 
A curva de calibração do sistema gravimétrico foi construída adicionando-se e retirando-se pesos padrão sobre c cilindro de medição.

Nas Figuras de 6.8 a 6.22 , para uma melhor percepção e caracterização, por parte do leitor, dos equipamentos e dispositivos de medição, de controle e de monitoramento utilizados, são apresentadas fotografias de diversos subconjuntos do experimento, destacando-se os principais componentes. 


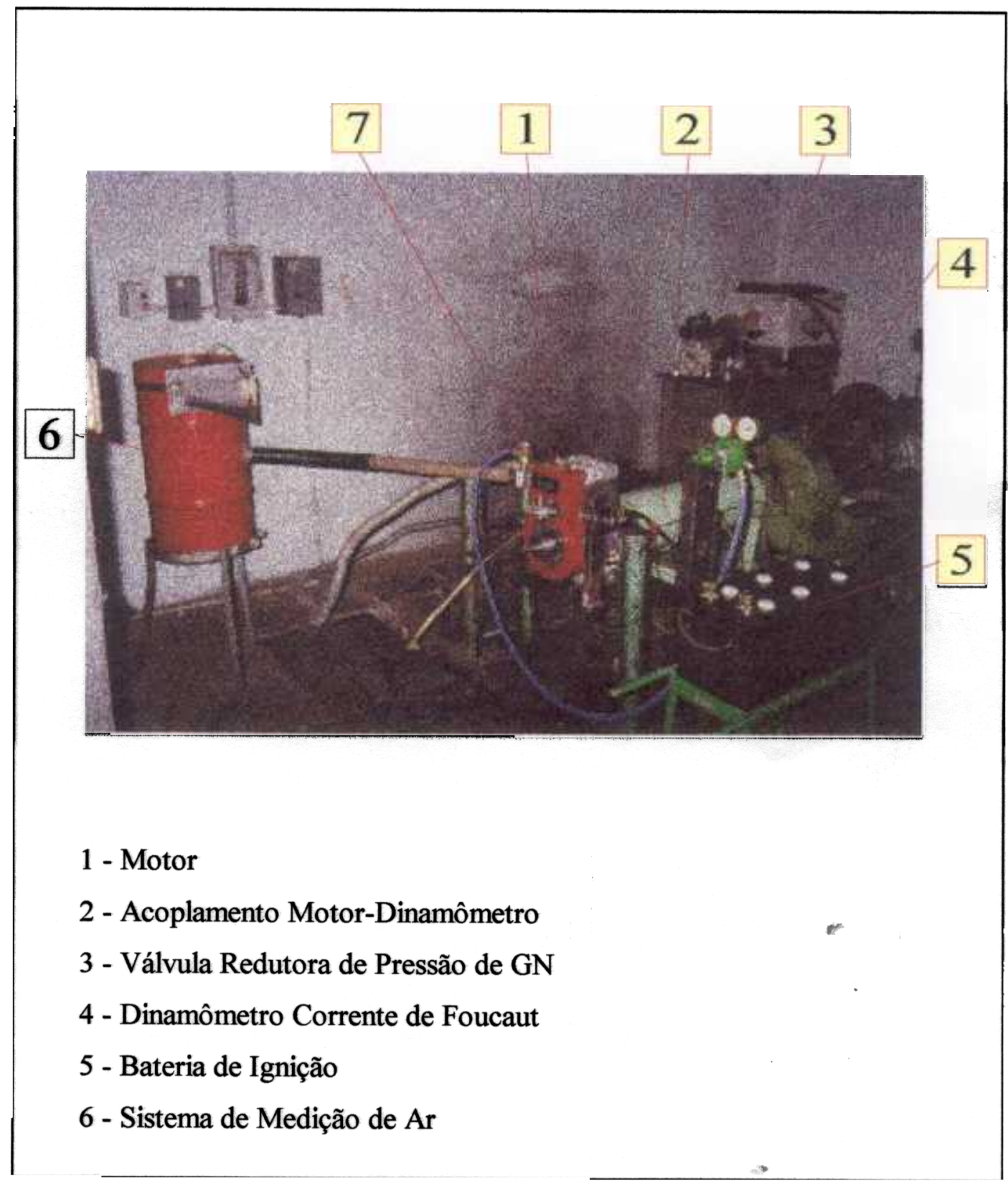

FIGURA 6.8. - Vista Geral do Motor no Dinamômetro. 


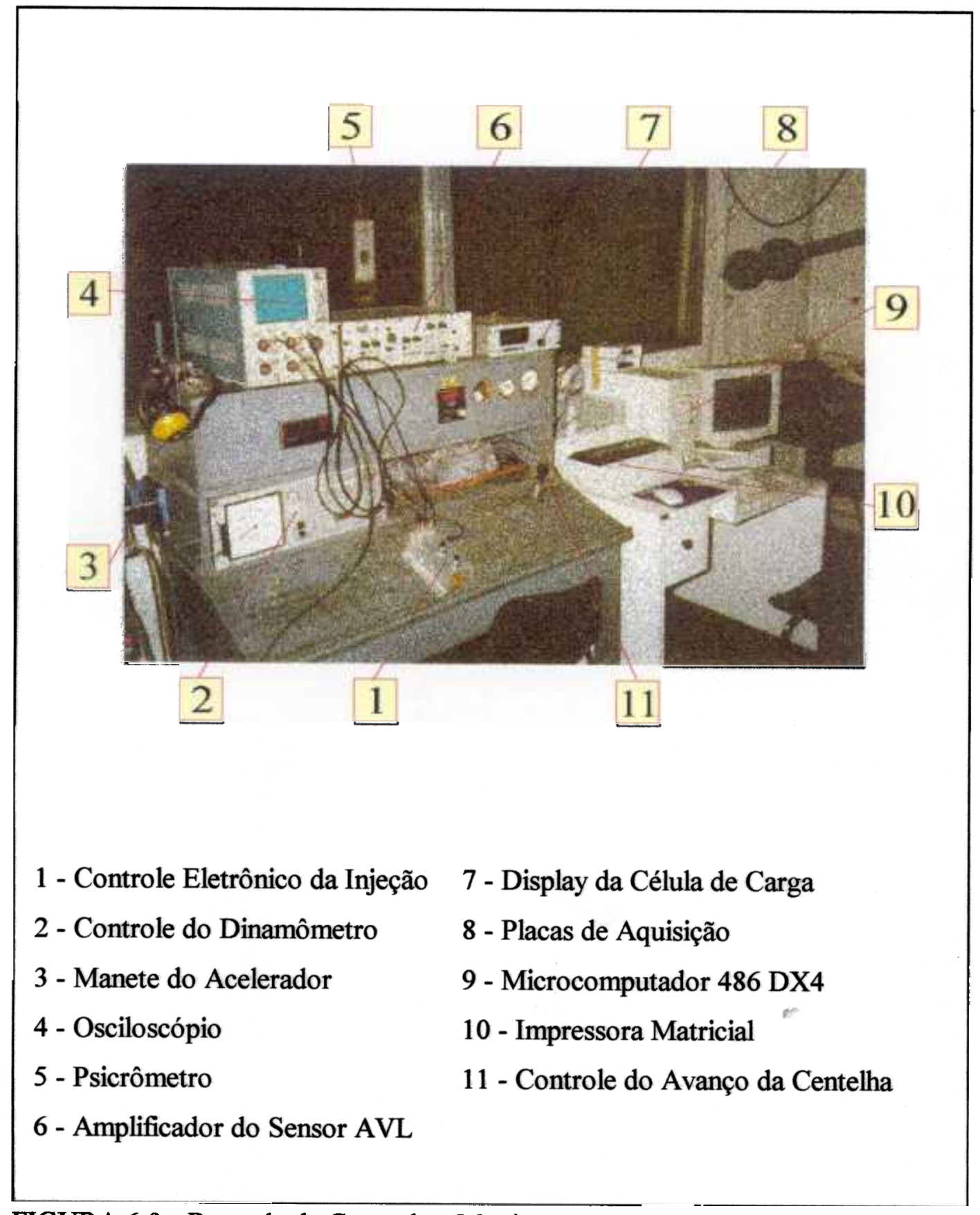

FIGURA 6.9 - Bancada de Controle e Monitoramento. 


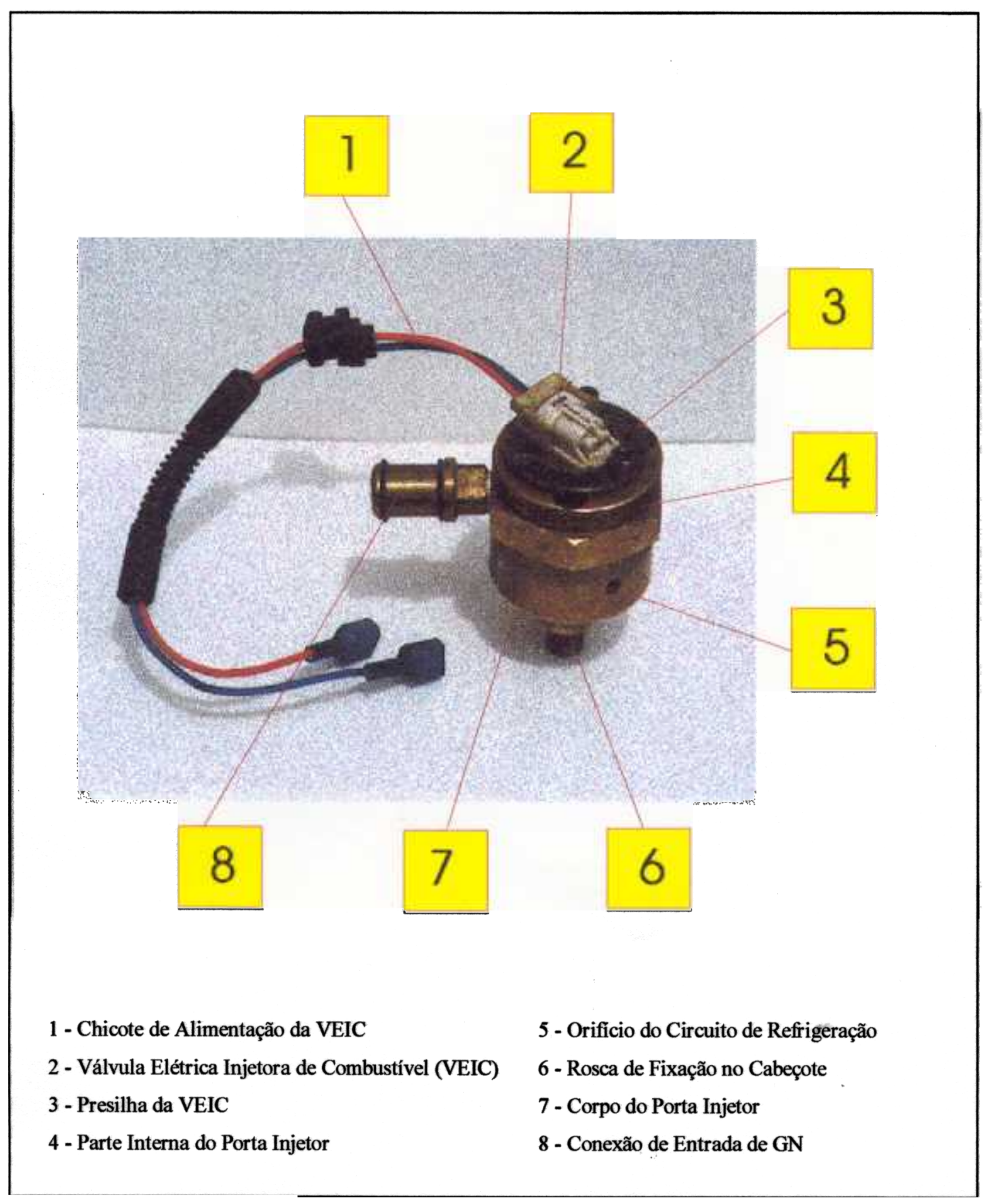

FIGURA 6.10 - Conjunto de Injeção Direta de Gás Natural. 


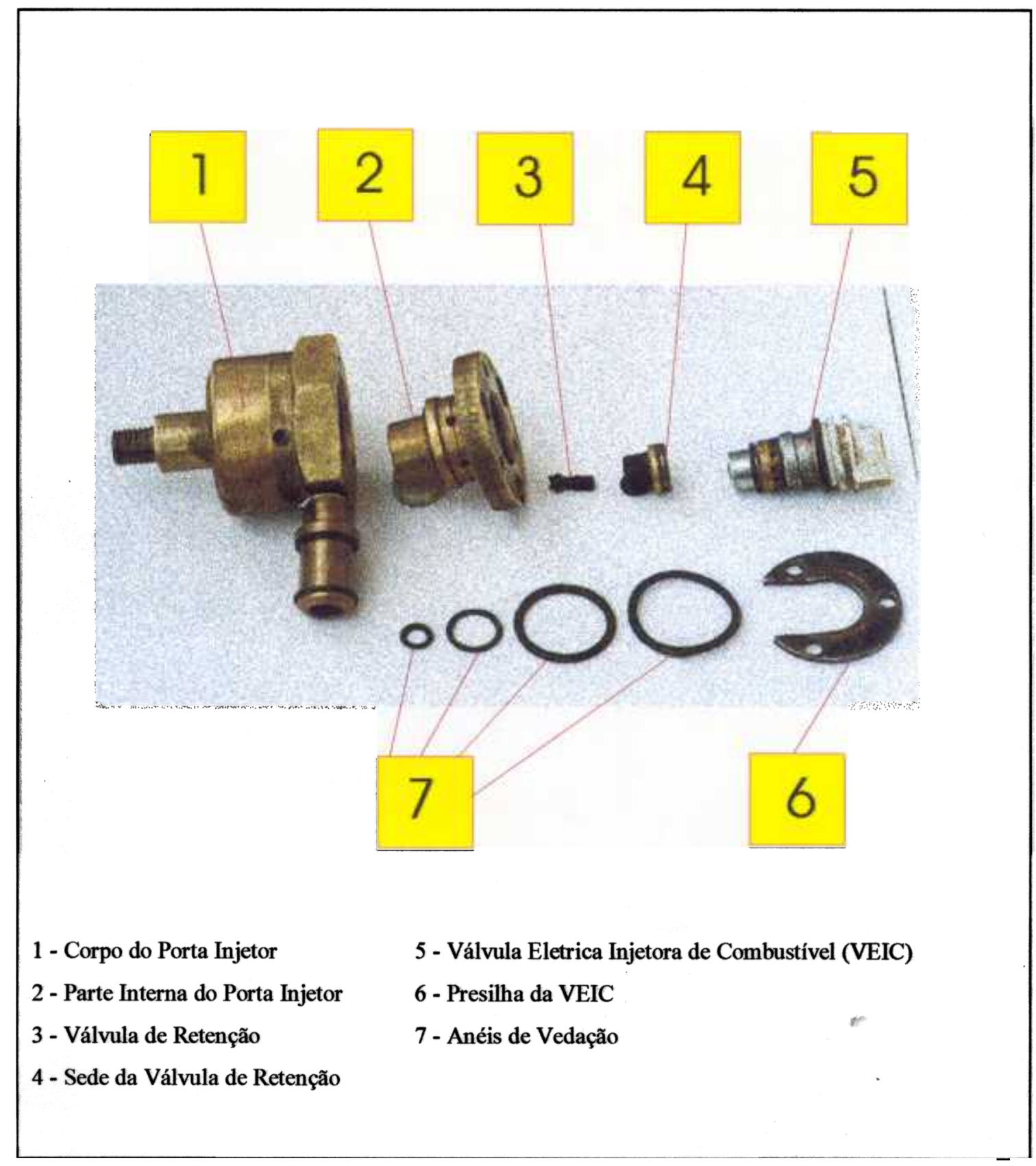

FIGURA 6.11 - Vista Lateral dos Componentes do Conjunto de Injeção Direta de GN. 


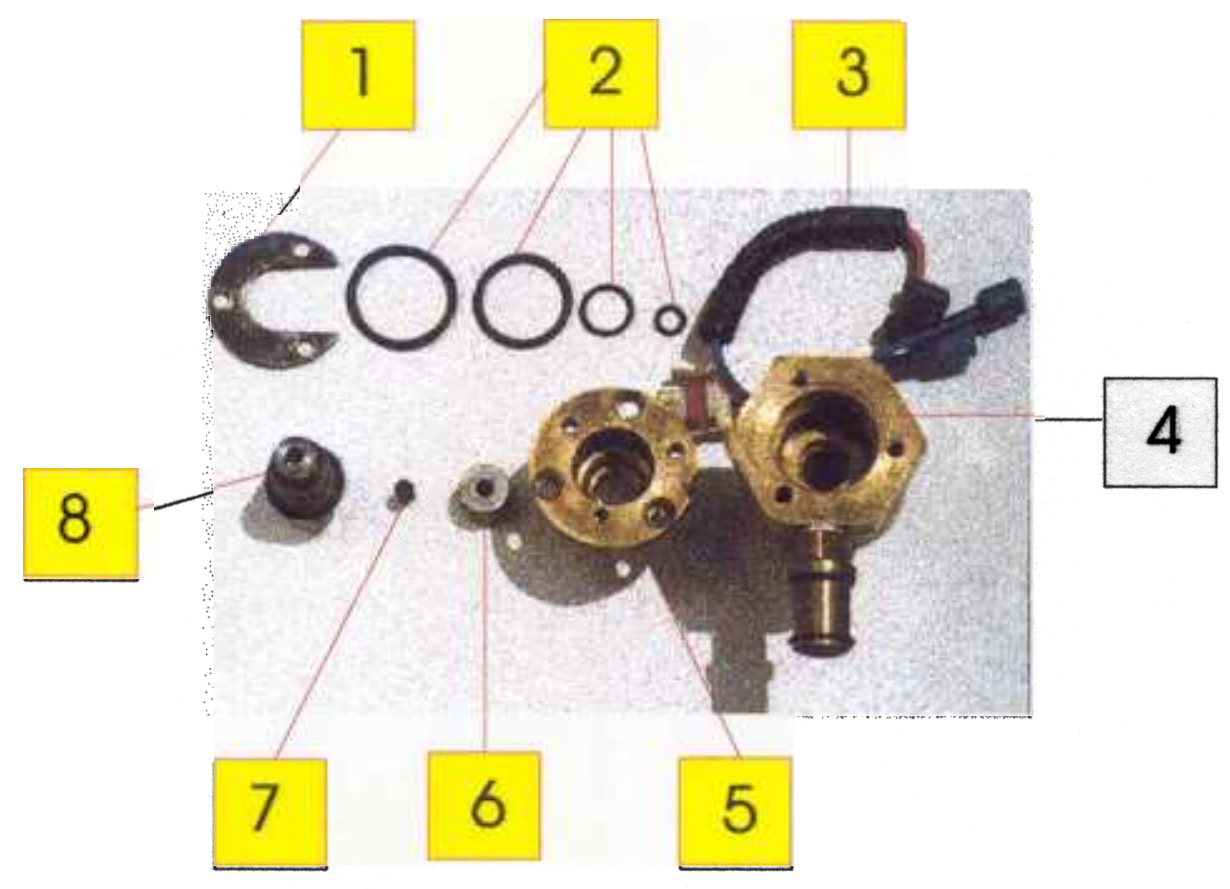

1 - Presilha da VEIC

5 - Parte Interna do Porta Injetor

2 - Anéis de Vedação

6 - Sede da Válvula de Retenção

3 - Chicote de Alimentação da VEIC

7 - Válvula de Retenção

4 - Corpo do Porta Injetor

8 - Válvula Elétrica Injetora de Combustível (VEIC)

FIGURA 6.12 - Vista de Topo dos Componentes do Conjunto de Injeção Direta de Gás Natural. 


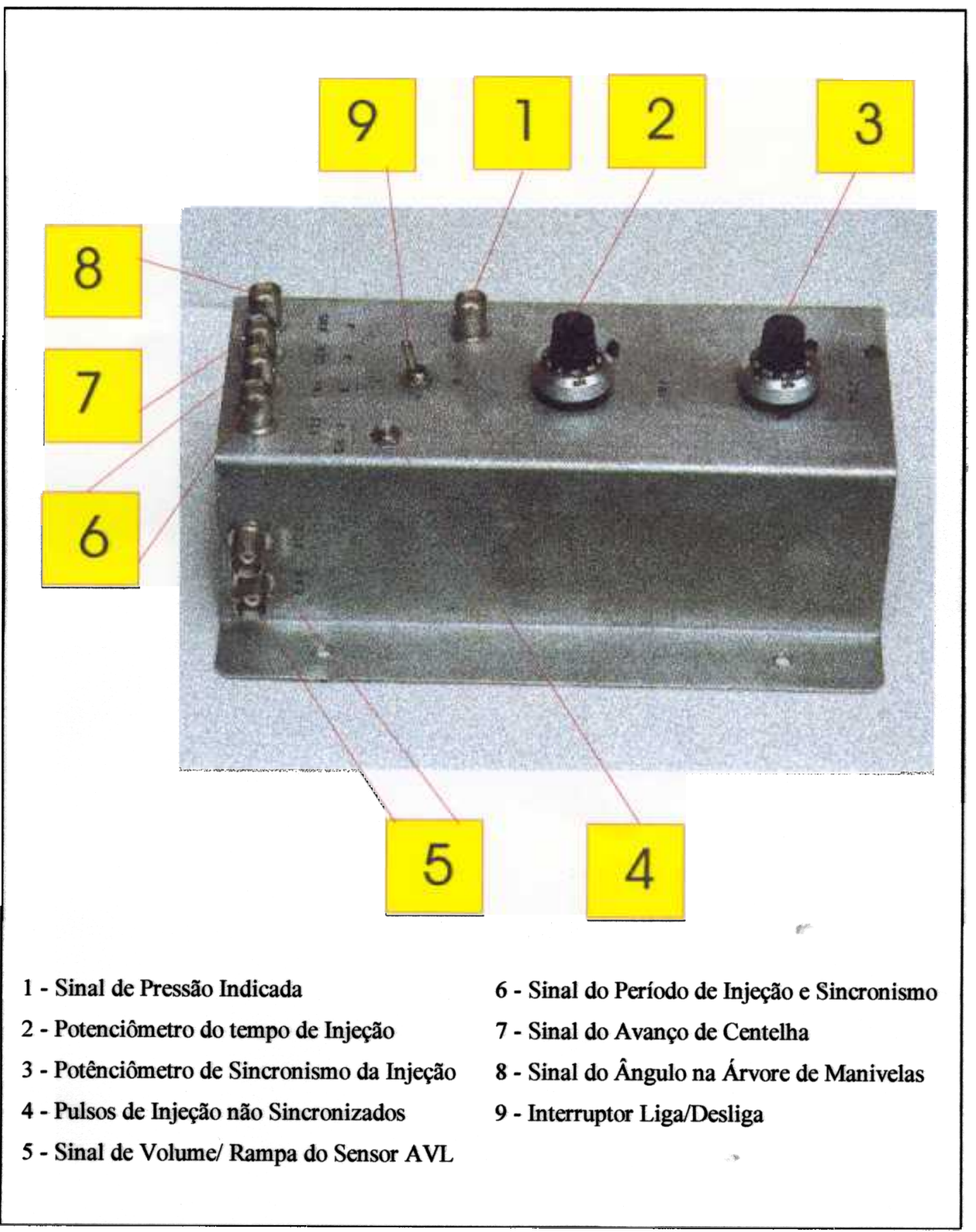

FIGURA 6.13 - Vista Superior da Unidade de Gerenciamento Eletrônico da Injeção de GN com Sinais de Monitoramento da Injeção e Ignição Transistorizada do Motor de Testes. 


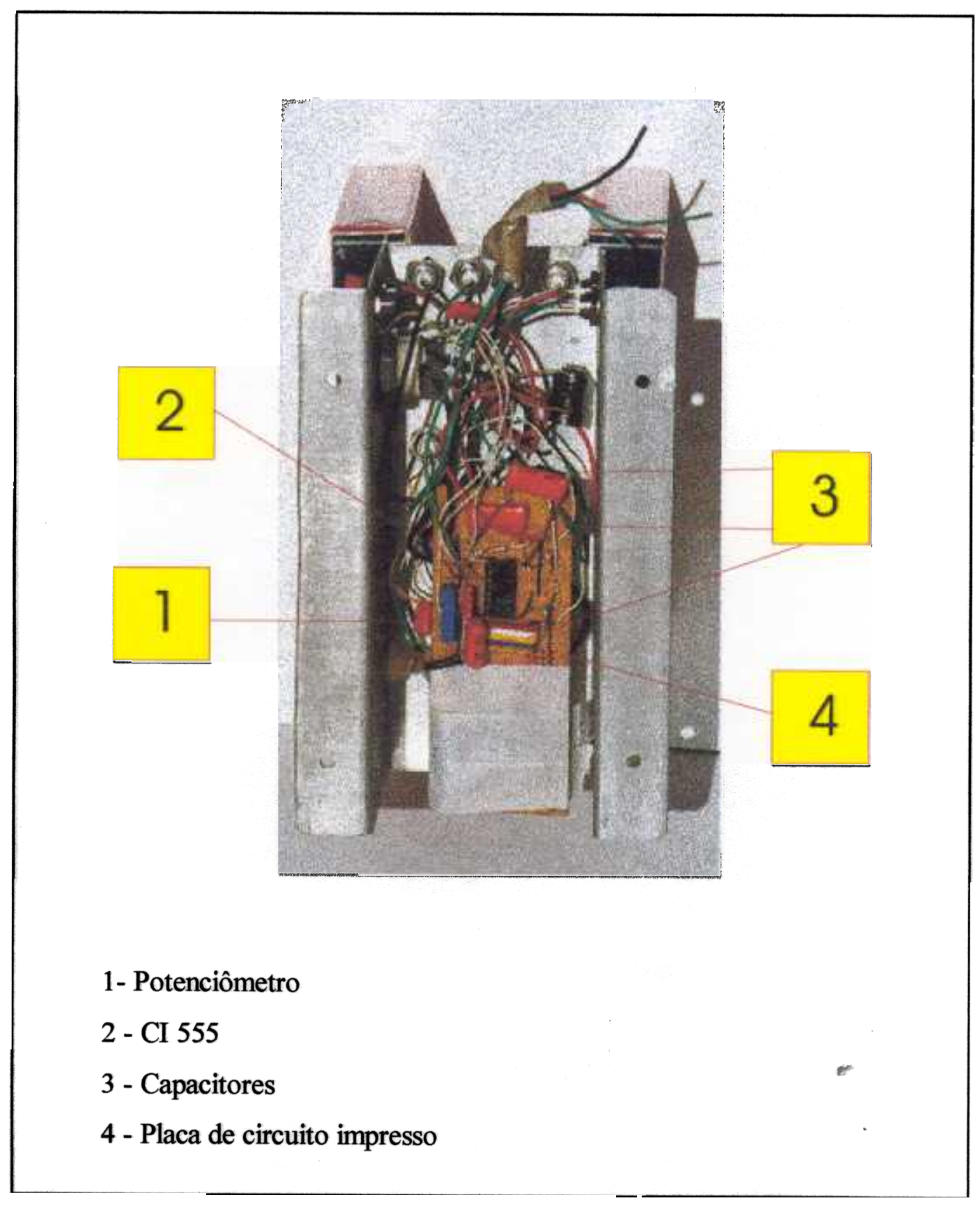

FIGURA 6.14 - Vista Inferior do Sistema de Controle da Injeção de Gás Natural. 


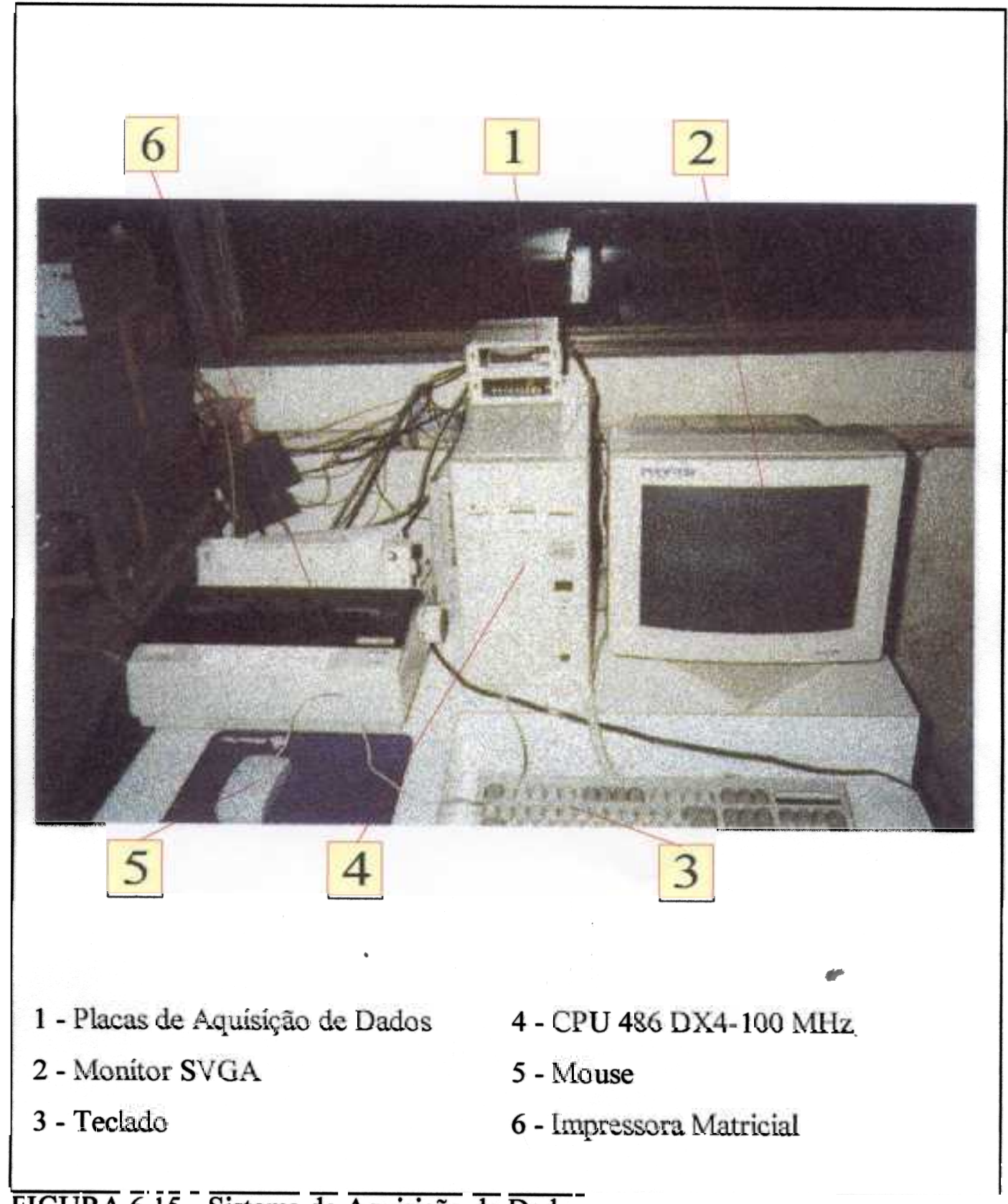

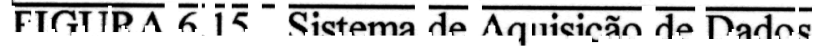




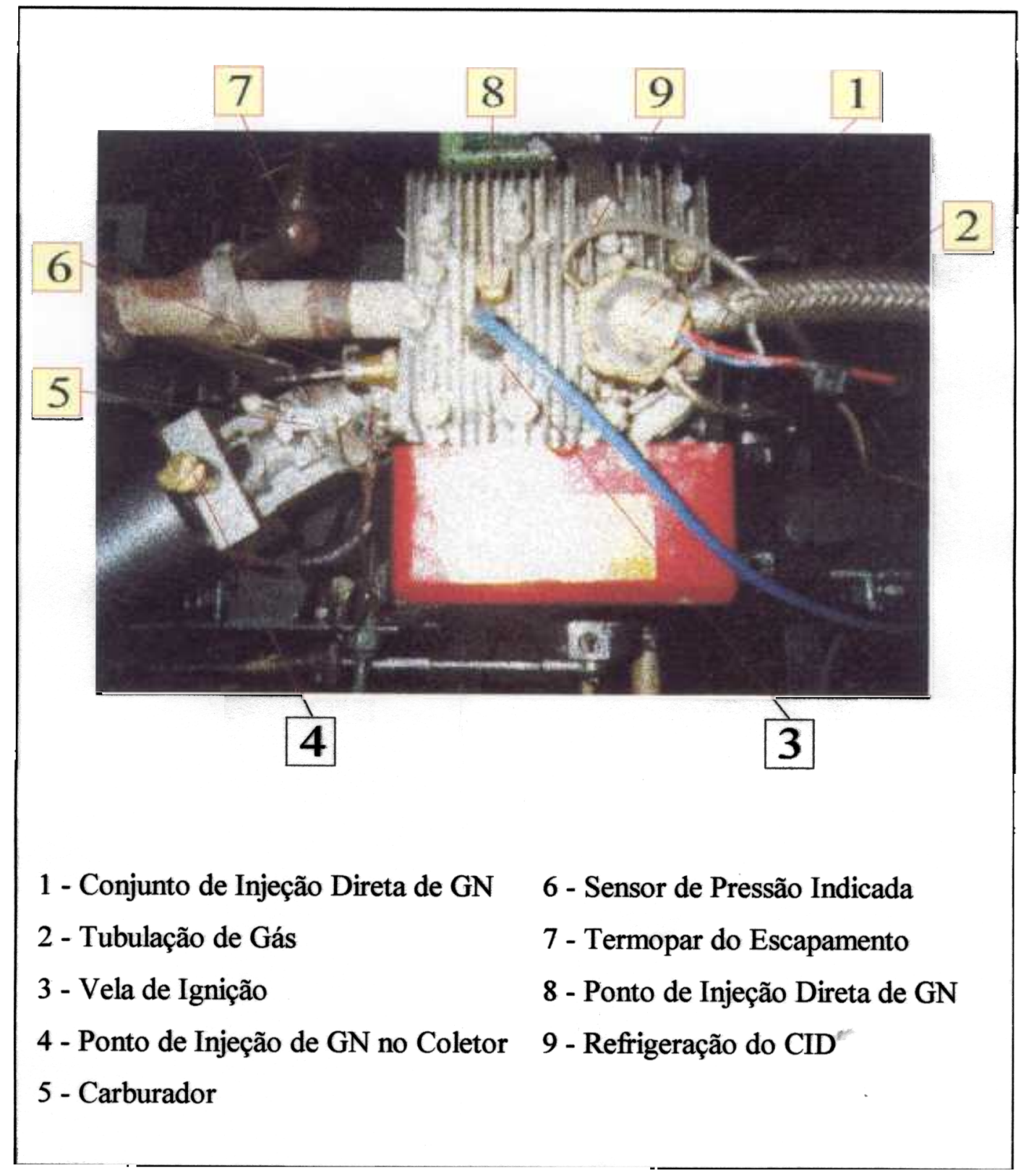

FIGURA 6.16 - Vista Superior do Motor de Testes. 


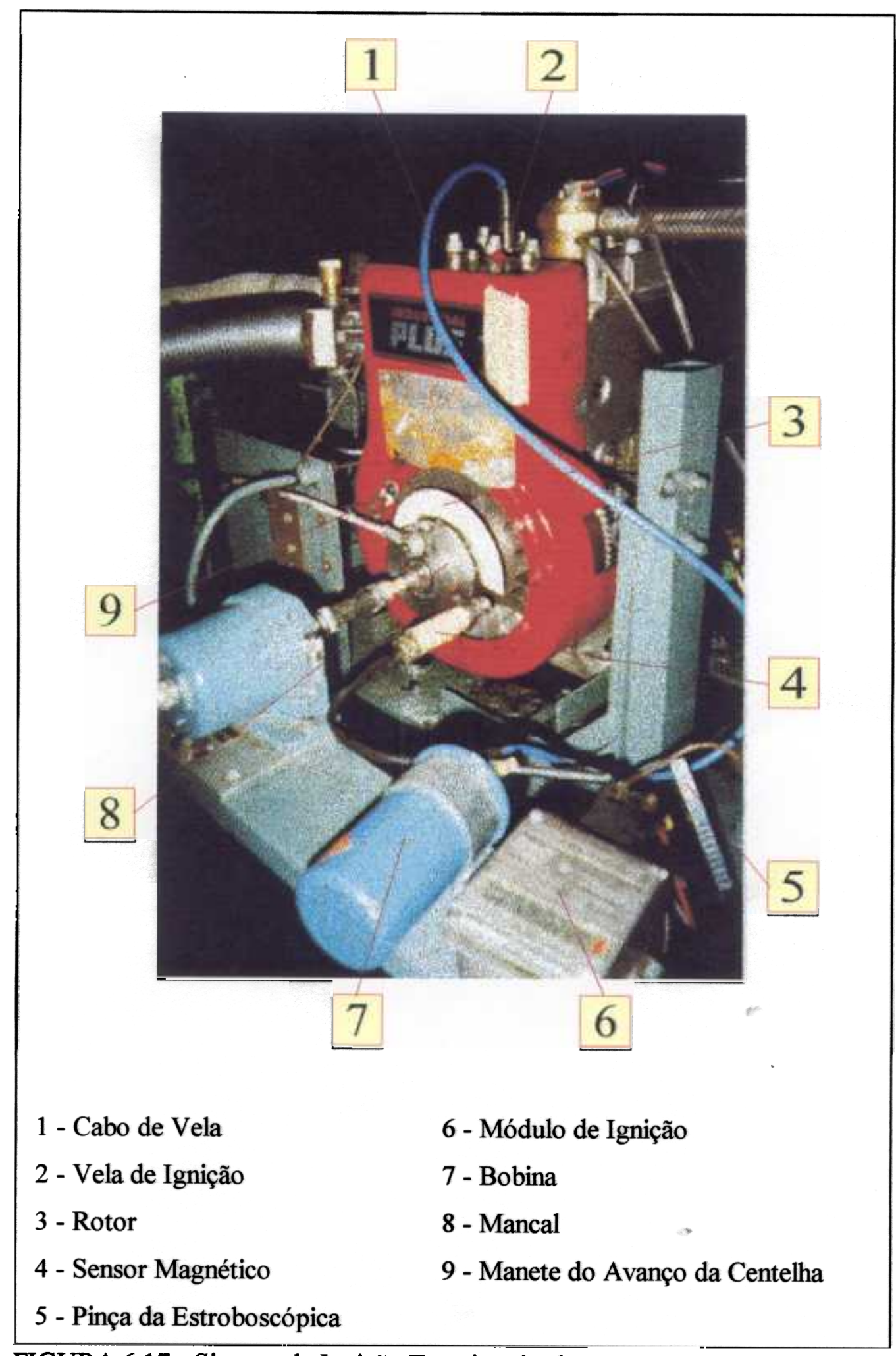

FIGURA 6.17 - Sistema de Ignição Transistorizada. 


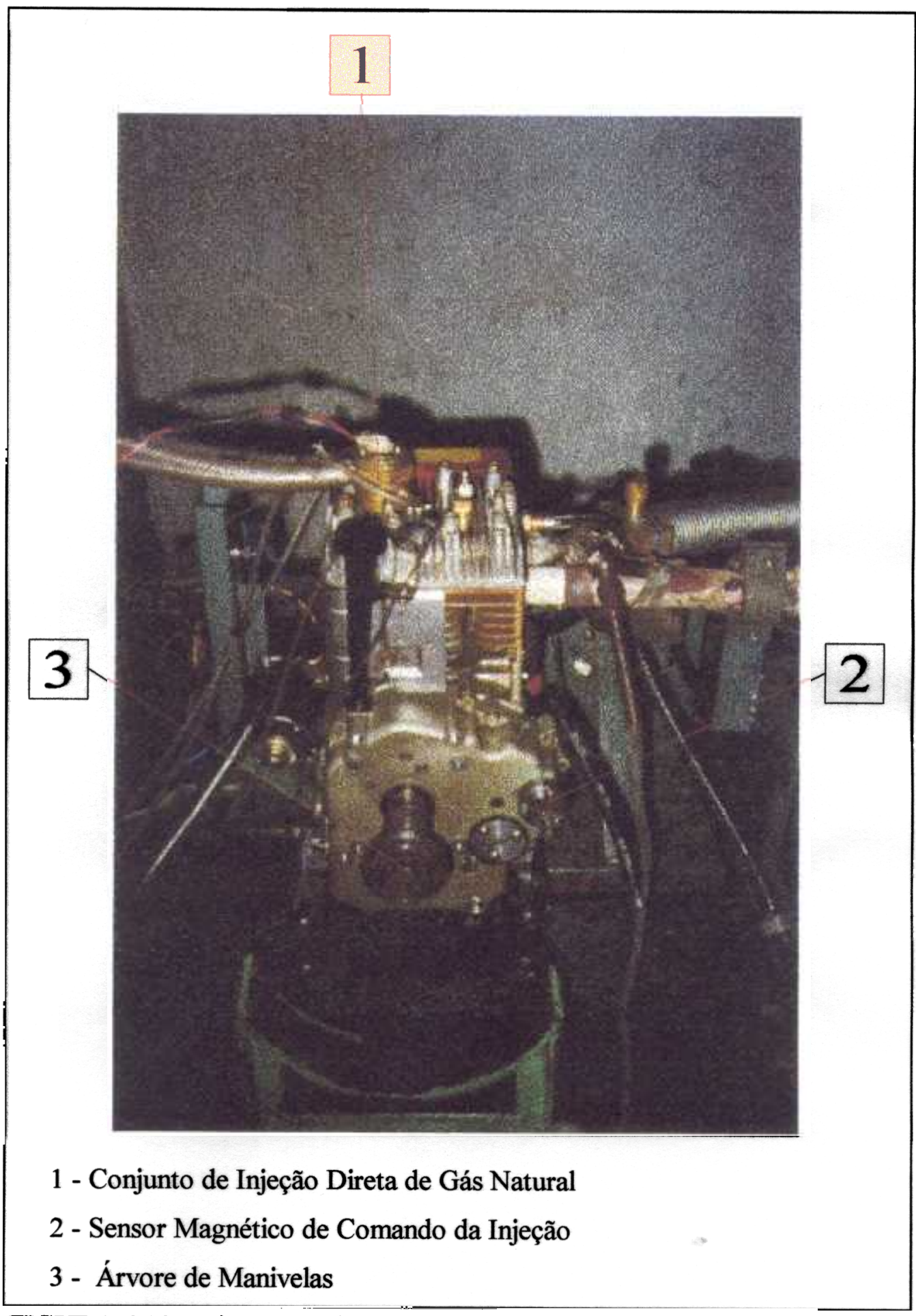

FIGURA 6.18 - Vista Posterior do Motor. 


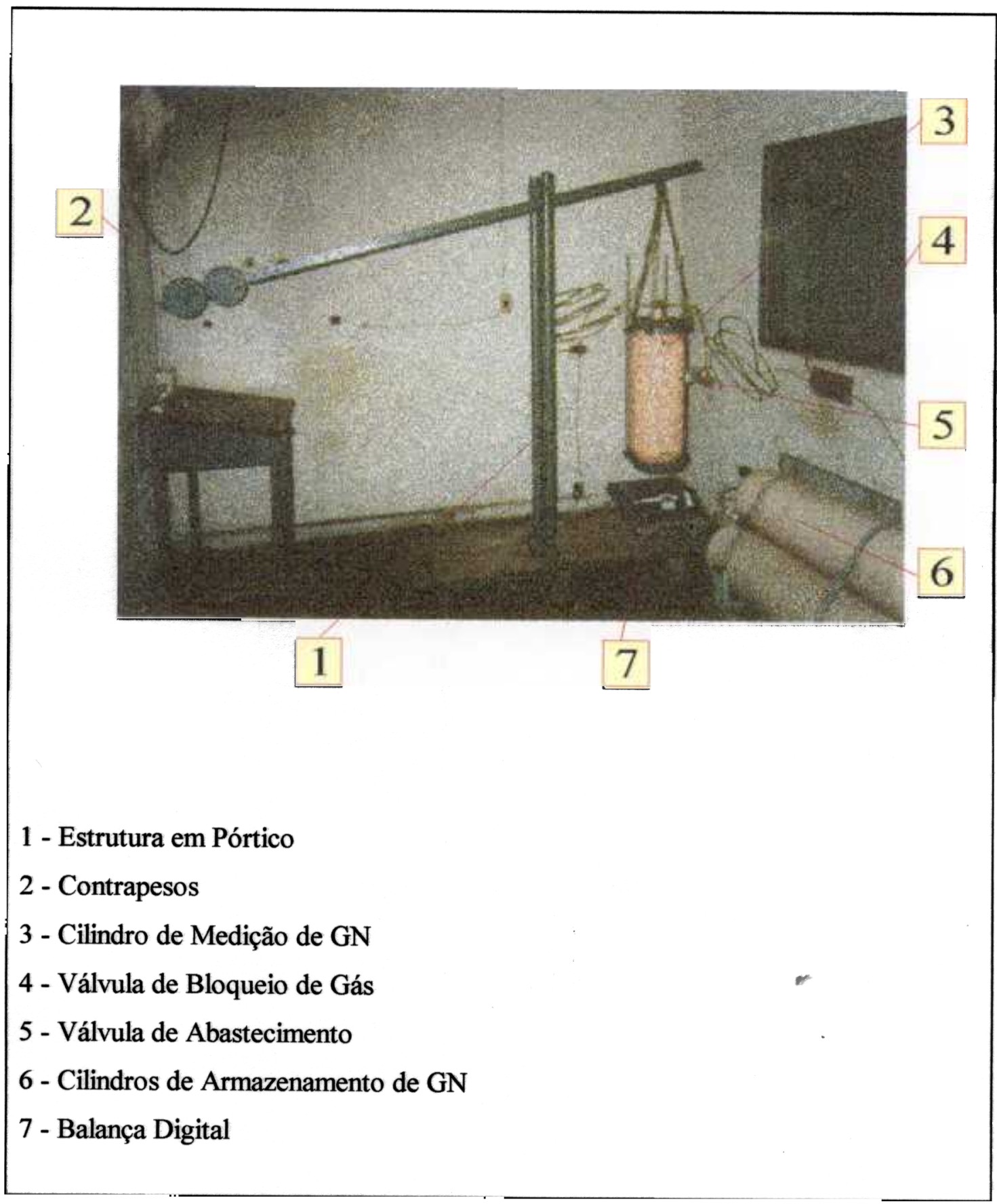

FIGURA 6.19 - Sistema de Medição do Consumo de Gás Natural. 


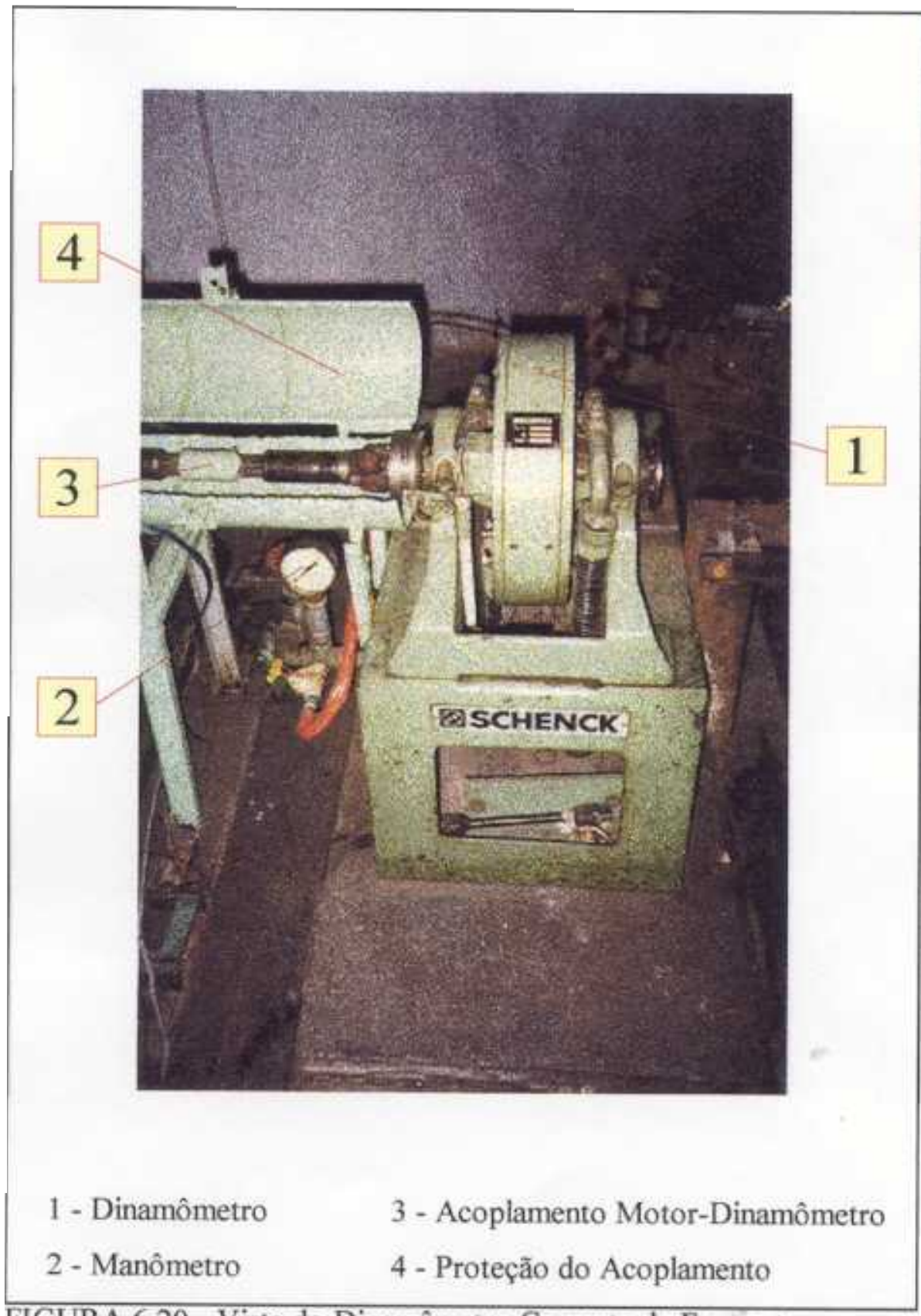

FIGURA 6.20 - Vista do Dinamômetro Corrente de Foucaut. 


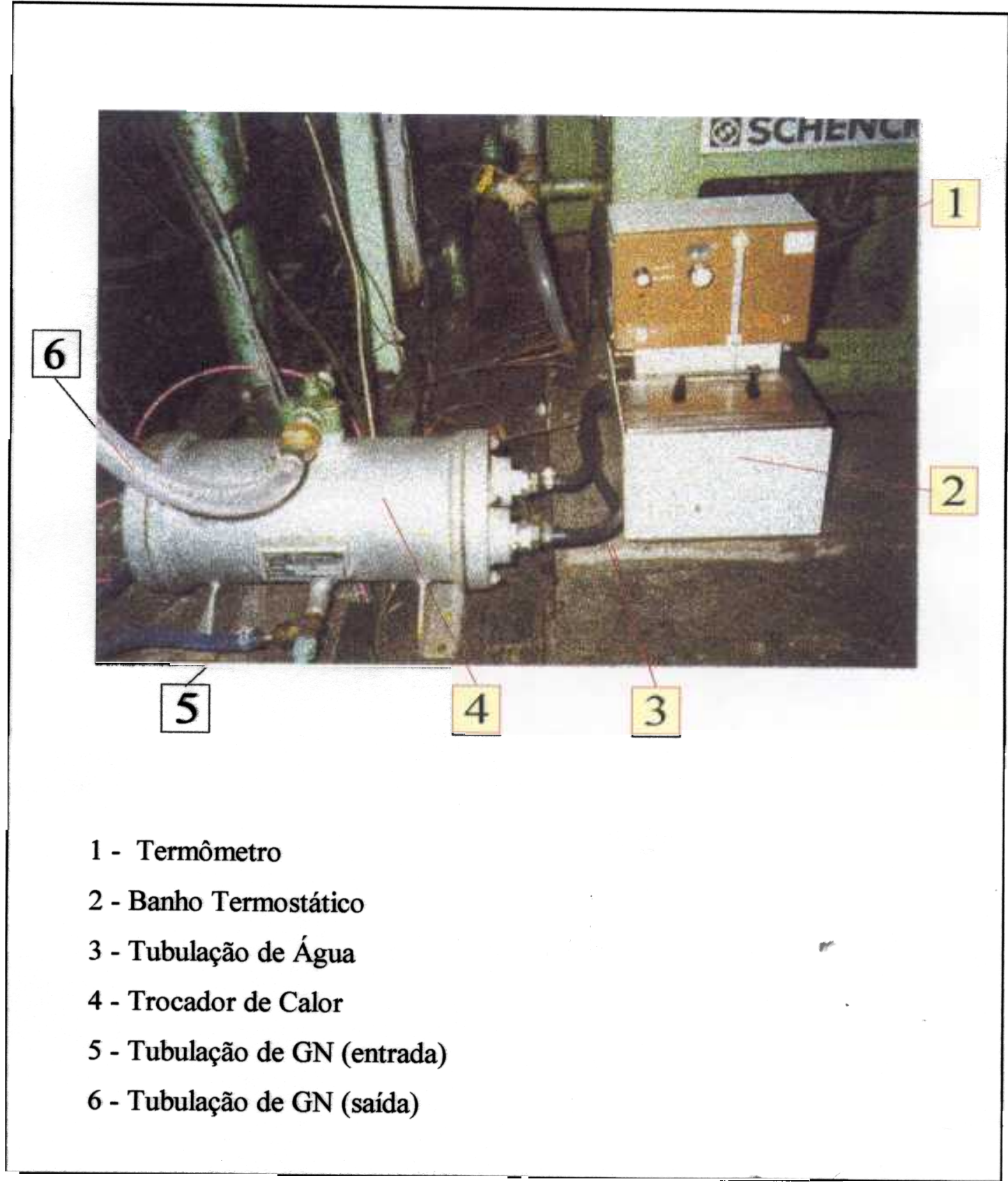

FIGURA 6.21 - Sistema de Aquecimento de Gás Natural para o Motor. 


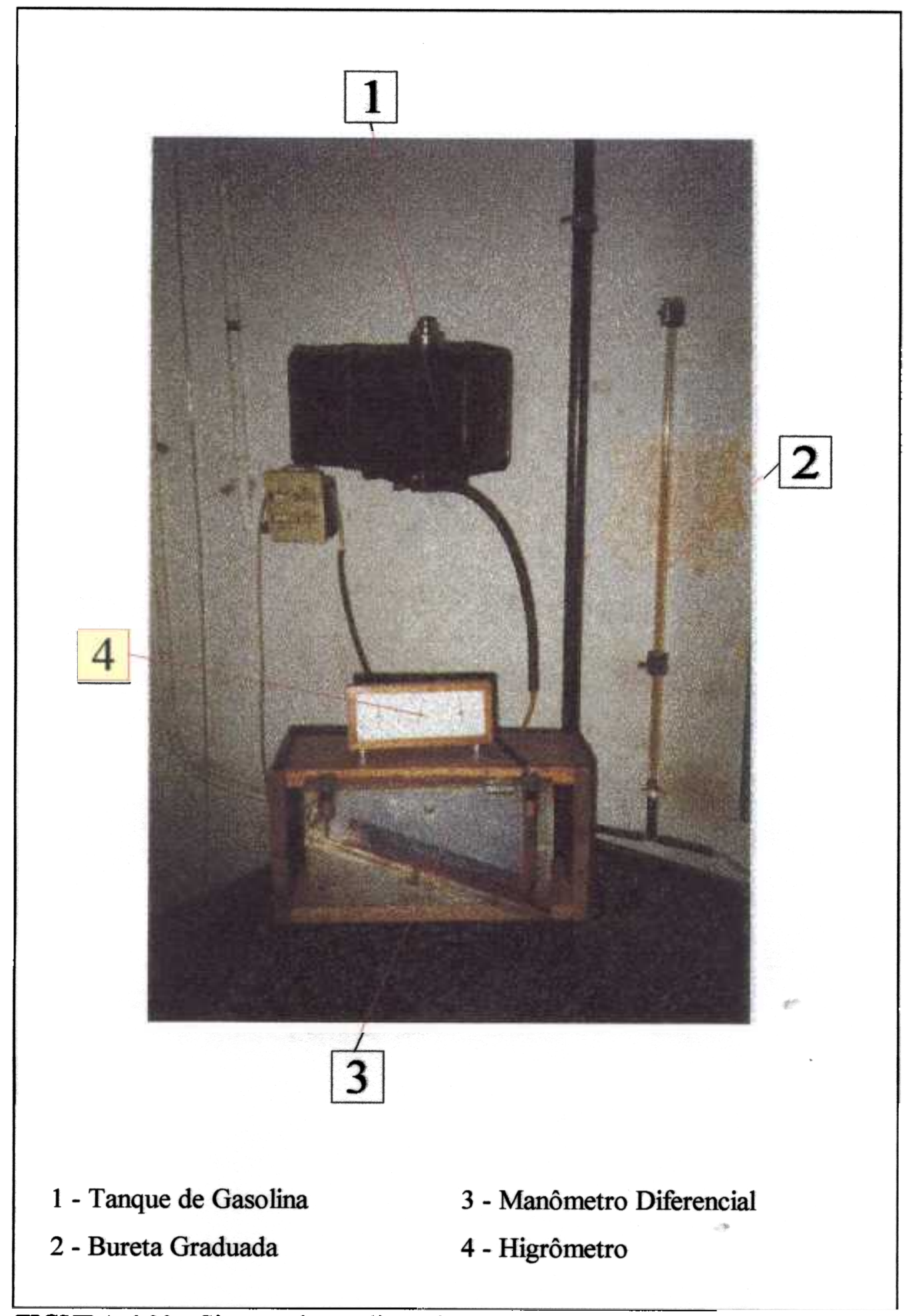

FIGURA 6.22 - Sistema de Medição do Consumo de Gasolina. 


\section{CAPÍTULO 07 - RESULTADOS E ANÁLISE}

\section{1 - SISTEMA DE INJEÇÃO DIRETA DE GÁS NATURAL}

Nos testes iniciais de avaliação do conjunto de injeção direta de gás natural, inserido no cabeçote do motor ensaiado, os principais problemas encontrados foram

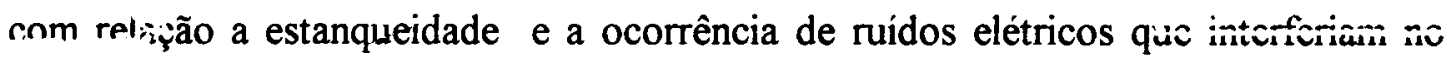
controle eletrônico da injeção, promovendo pulsos de injeção não sincronizados e indesejáveis.

A estanqueidade do conjunto de injeção, refere-se à vedação entre o combustivel gás natural, a água de refrigeração do conjunto de injeção e os gases da câmara de combustão. O problema da estanqueidade do conjunto de injeção foi resolvido, reforçando-se o sistema de vedação mediante o aumento do número de anéis de vedação. No total, foram utilizados 06 anéis de vedação para assegurar a estanqueidade do sistema.

A interferência de ruídos elétricos na injeção, provenientes do sistema de ignição do motor, somente foi resolvido mediante a mudança da posição do conjunto de injeção para uma posição mais afastada da vela de ignição e pelo emprego de filtros capacitivos na unidade de gerenciamento eletrônico da injeção e utilização de 
cabo de vela de ignição resistivo. A Figura 6.16. , mostra as diferentes posições de instalação do conjunto de injeção direta no cabeçote do motor de testes.

Após a solução destes problemas, foi possivel estabelecer o regime de plena carga nas rotações de ensaio, entre 2000 e 3000 rpm. Entretanto, nas altas rotações, devido às limitações dimensionais da $\mathrm{VEIC}^{1}$, o conjunto de injeção operando na pressão máxima e maior largura de pulso possivel, não fornecia combustível suficiente para estabelecer o regime de plena carga. Para solucionar tal impasse, o sincronismo da injeção foi modificado, possibilitando assim, aumentar a largura máxima de pulso de injeção (duração da injeção) por ciclo. O sensor magnético de comando da injeção que antes era sincronizado com o PMS do curso de admissão, passou então, à posiçãn do PMI no inicio do curso de exaustão. Tal modificação surtiu efeito, e assim, f j: possível estabelecer o regime de plena carga em todas as rotações de ensaio.

Para avaliar o inércia da válvula de retenção no processo de injeção, o motor foi ensaiado em regime de plena carga e em todas as rotações de ensaio, com o conjunto de injeção de GN, inserido no coletor de admissão, à montante da válvula borboleta do acelerador, operando a 8,5 bar de pressão, com e sem válvula de retenção. Os resultados mostram um aumento percentual de 7 a 16\%, majorado com o aumento da rotação do motor, na largura de pulso da injeção, para estabelecer o melhor torque em cada rotação de ensaio. O torque do motor nas duas situações permaneceu inalterado, uma vez que, a injeção de GN poderia ser realizada

\footnotetext{
${ }^{1}$ A Válvula eletrônica injetora de combustivel (VEIC) utilizada no experimento era de um motor a álcool 1.8 litros. Para injeção de GN, foi ajustado o "GAP" da VEIC para condição de melhor resposta do motor em termos de torque a $3000 \mathrm{rpm}$.
} 
praticamente durante todo o ciclo motor. O combustível injetado após o fechamento da válvula de admissão, permanecia no coletor de admissão, sendo queimado no ciclo posterior.

\section{2 - DESEMPENHO DO MOTOR}

As curvas de desempenho apresentadas nas Figuras 7.1 a 7.8 permitem visualizar o desempenho do motor de testes funcionando em regime de plena carga, com injeção eletrônica de gás natural a baixas pressões na câmara de combustão, ou com injeção eletrônica de gás naturaí. à ïıuniante da válvula borìoleta do acelerador, no coletor de admissão, ou ainda com gasolina caiburada. As curvas apresentadas foram obtidas, a partir dos dados experimentais, por regressão polinomial empregando-se o método dos mínimos quadrados. Os coeficientes de correlação $\left(R^{2}\right)$, são apresentados do lado esquerdo das respectivas curvas de regressão.

Nas planilhas de ensaio 7.1 a 7.6, são apresentados dados experimentais correspondentes (medidos e calculados) do motor de testes operando com injeção direta de GN, injeção de GN no coletor de admissão ou ainda com carburação convencional de gasolina, para o regime de plena carga.

O monitoramento do motor com injeção direta de GN no curso de admissão, durante a variação de alguns parâmetros de operação tais como: razão arcombustivel, avanço da centelha, sincronismo da injeção, pressão de injeção etc, permitiu fazer as seguintes observações: 
a) $\mathrm{O}$ ajuste do avanço da centelha aumenta o torque e a potência do motor, melhorando o consumo específico de combustivel;

b) O torque do motor é muito sensível à razão ar-combustível, a qual era ajustada eletronicamente, controlando-se a quantidade de gás natural injetado.

c) $O$ sincronismo da injeção também causa grandes variações no torque do motor. $O$ melhor torque do motor foi obtido com o inicio da injeção ocorrendo na parte final do curso de exaustão, durante o período de cruzamento das válvulas.

d) A avanço da injeção de GN, isto é, a injeção mais cedo no curso de admissão, muito provavelmente, melhorava o processo de formação da mistura ar-GN dentro do cilindro, proporcionando uma mistura mais homogênea. Porém, parte do combustível injetado durante o cruzamento de válvulas, escoava pela jarela de exaustão, contribuindo assim para um aumento do consumo específico e redução do rendimento global, conforme ilustram as Figuras 7.4 e 7.5 , respectivamente.

e) A injeção direta durante o curso de compressão, como era pretendido inicialmente, não foi possível em virtude das características geométricas e da baixa turbulência da câmara de combustão em " $\mathrm{L}$ " do motor ensaiado. O GN, quando injetado na compressão, formava ali misturas demasiadamente ricas, além do limite de inflamabilidade. $\mathrm{O}$ corte repentino do motor, ou melhor, a queda brusca de torque era visivel quando a injeção de GN começava a entrar no curso de compressão.

f) A válvula eletrônica injetora de combustível (VEIC), mesmo operando com a pressão de injeção máxima de 8,5 bar, necessitava utilizar praticamente todo o curso de admissão para estabelecer o regime de plena carga. 
g) Na injeção direta, sincronizada com o curso de admissão, o tempo disponível para injeção de gás natural (GN) diminuía com o aumento da rotação do motor. Ao mesmo tempo, as necessidades de combustível cresciam, pois as quantidades de ar aspirado pelo motor aumentavam com a elevação da rotação do motor, conforme ilustram as Figuras 7.7 e 7.8 , respectivamente.

Os dados de potência e torque máximos especificados pelo fabricante foram obtidos experimentalmente, atestando o bom estado do motor

No regime de plena carga, o motor com injeção de GN, apresentou uma queda de potência e torque da ordem de $20 \%$ em relação à operação com gasolina, estando compatível com os dados encontrados na literatura.

Esta perd $\hat{\imath}$ de potência e torque observada pode ser atribuída principalmente a menor eficiência volumétrica do motor a gás (em média $8 \%$ de queda em relação à gasolina), ao maior conteúdo energético da mistura ar-gasolina e também a baixa taxa de compressão do motor de testes a qual não permite o melhor aproveitamento das propriedades do metano.

A queda, já esperada, do torque e potência do motor funcionando com injeção no coletor de GN pode, conforme já citada na literatura, ser recomposta melhorandose o rendimento térmico através do aumento da taxa de compressão para adequá-la ao uso do GN.

Apesar do projeto original do motor não ser adequado ao GN, observou-se um rendimento global $46 \%$ superior à gasolina. Tal fato é atribuído ao controle e formação mais homogênea da mistura ar-GN e ao excesso de gasolina liberado pelo 
carburador, uma vez que os orificios calibrados "gicleaus" de passagem da gasolina disponíveis e utilizados, são recomendados para operação do motor ao nível do mar, aonde normalmente o motor respira melhor, isto é, admite mais ar e portanto necessita de mais combustível para desenvolver maiores potências.

O rendimento térmico de um motor de quatro tempos pode também ser otimizado aumentando-se a densidade do ar de admissão por meio de superalimentadores, turboalimentadores ou ainda reduzindo-se as restrições aerodinâmicas ao fluxo de ar de admissão, através da otimização do projeto do sistema de admissão, aumento do número de válvulas ou otimização do diagrama de válvulas.

Uma outra possibilidane de mavimizacãa da rendinento volumétrico, consiste na injeção direta de combustível a altas pressj̃es, durante o estágio final do curso de compressão. Atualmente, esta técnica é alvo de pesquisas nos países como Japão, EUA e Alemanha, inclusive utilizando-se combustíveis líquidos e gases liqüefeitos (hidrogênio). 


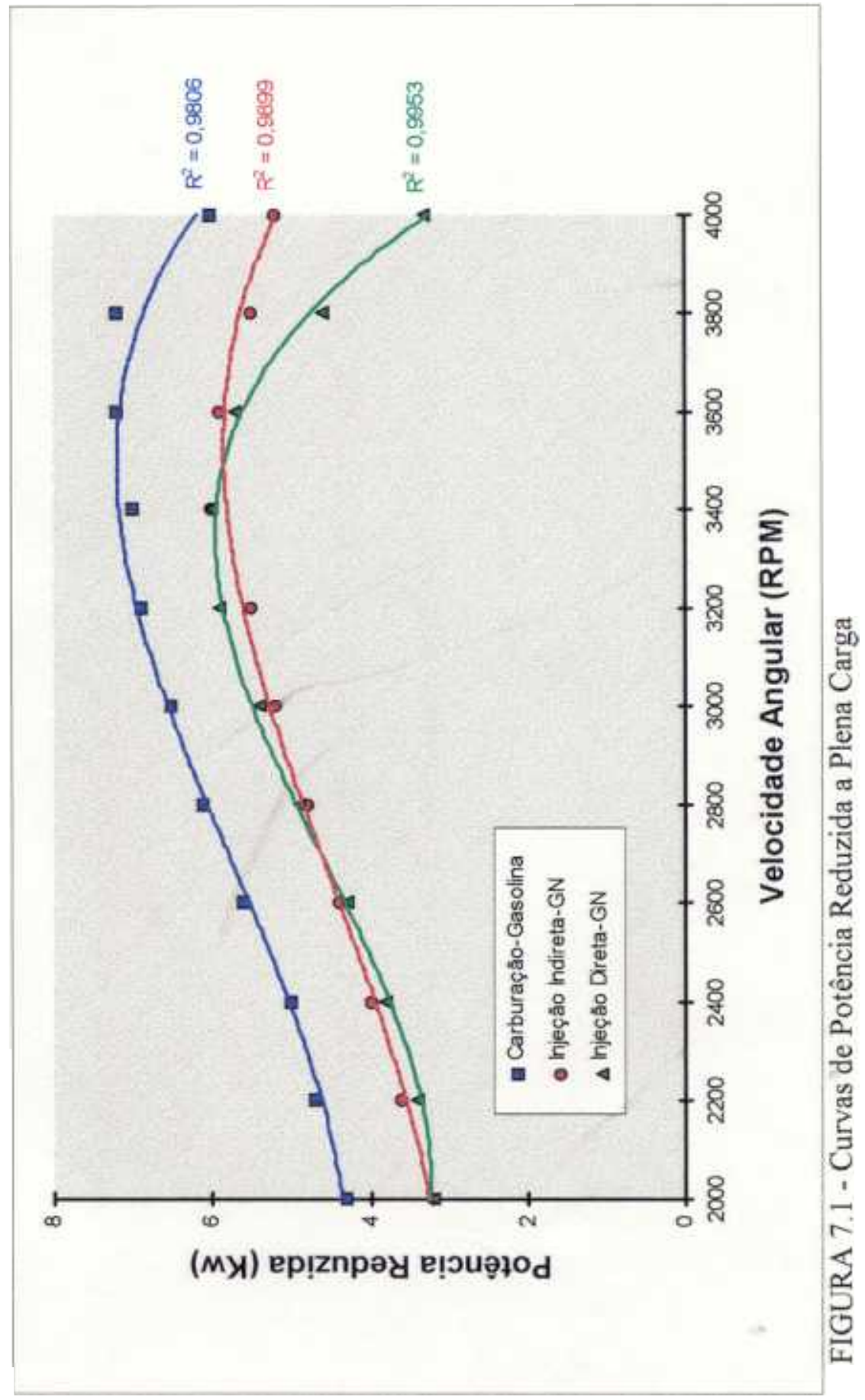




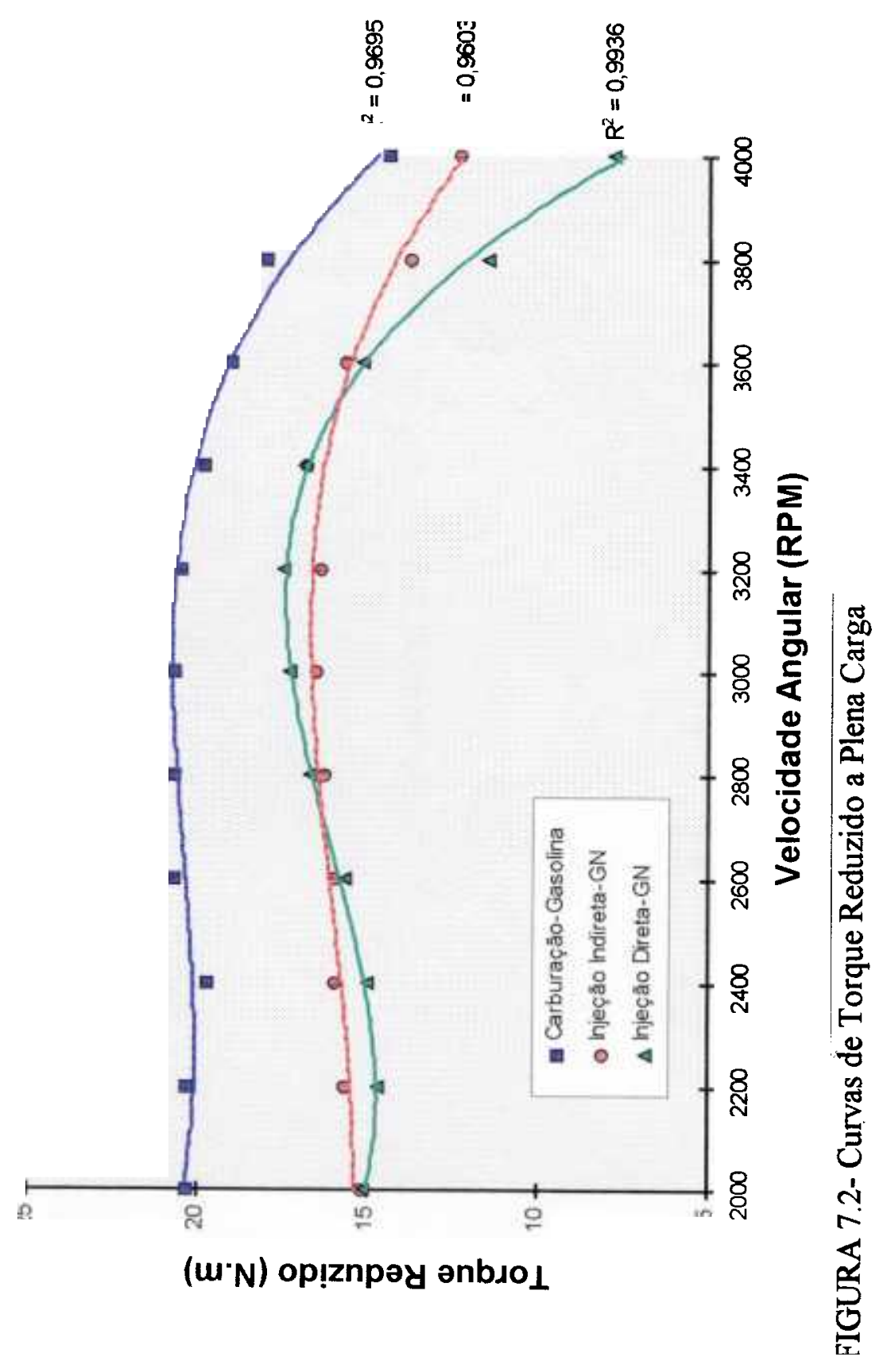




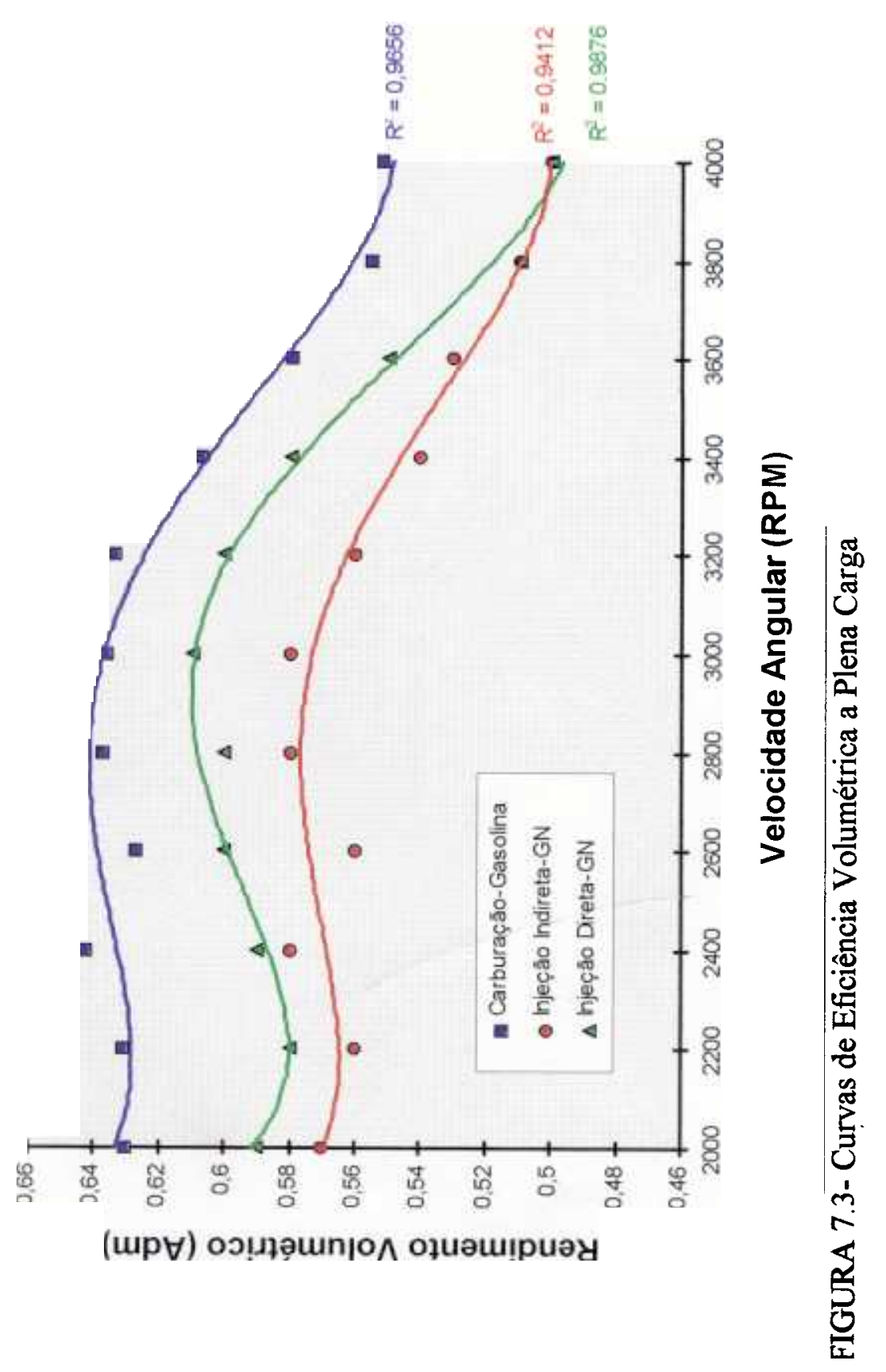




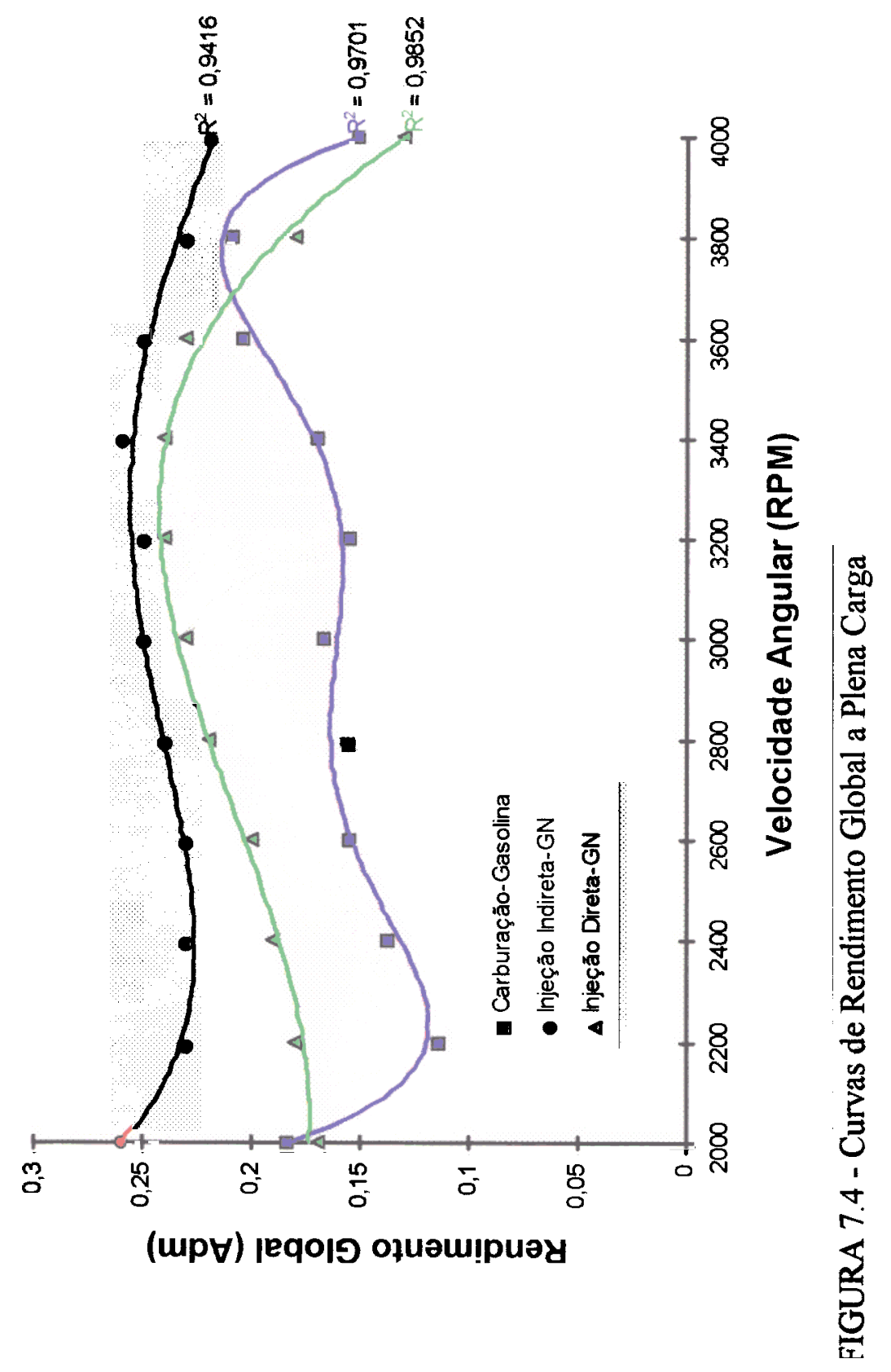




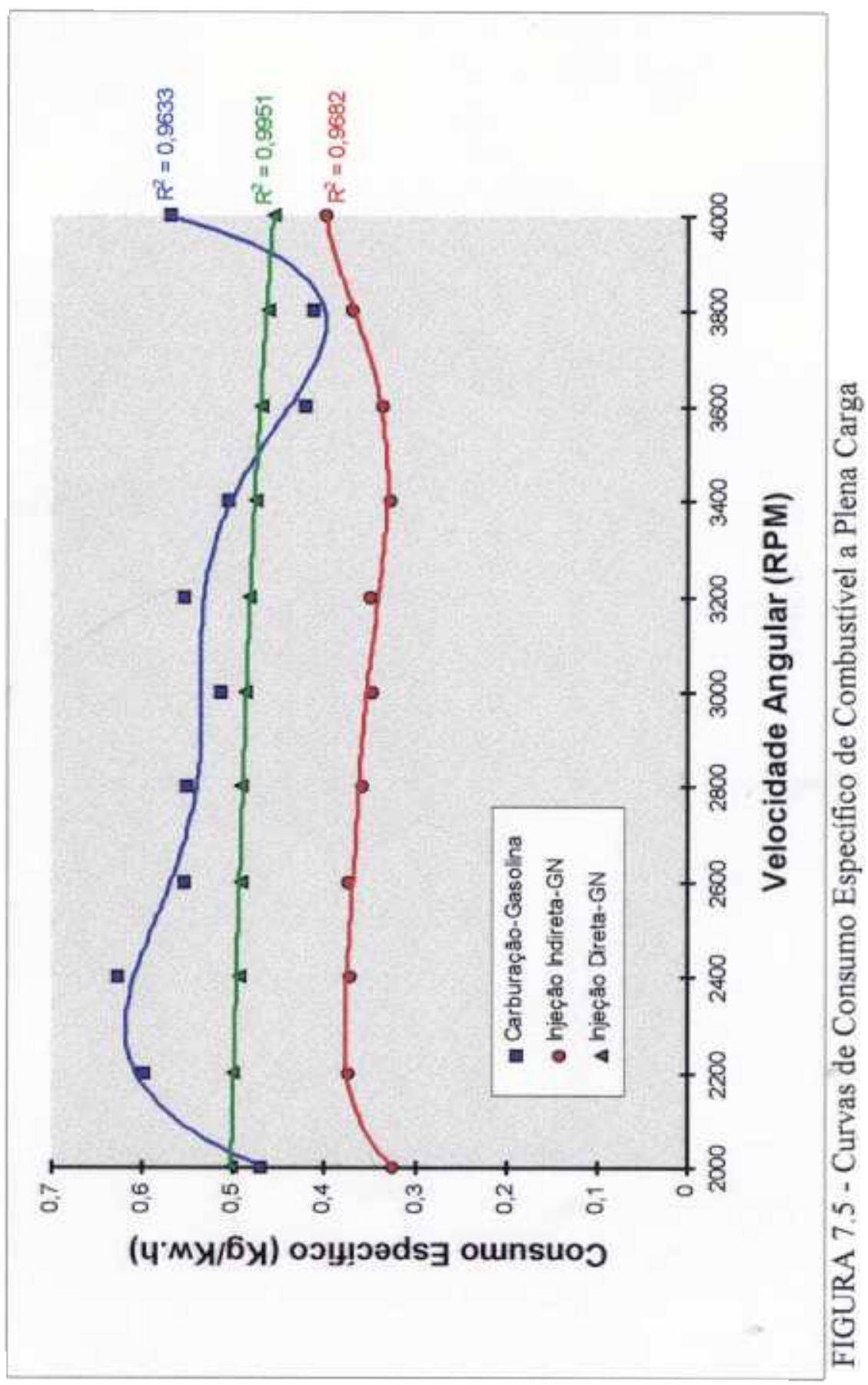




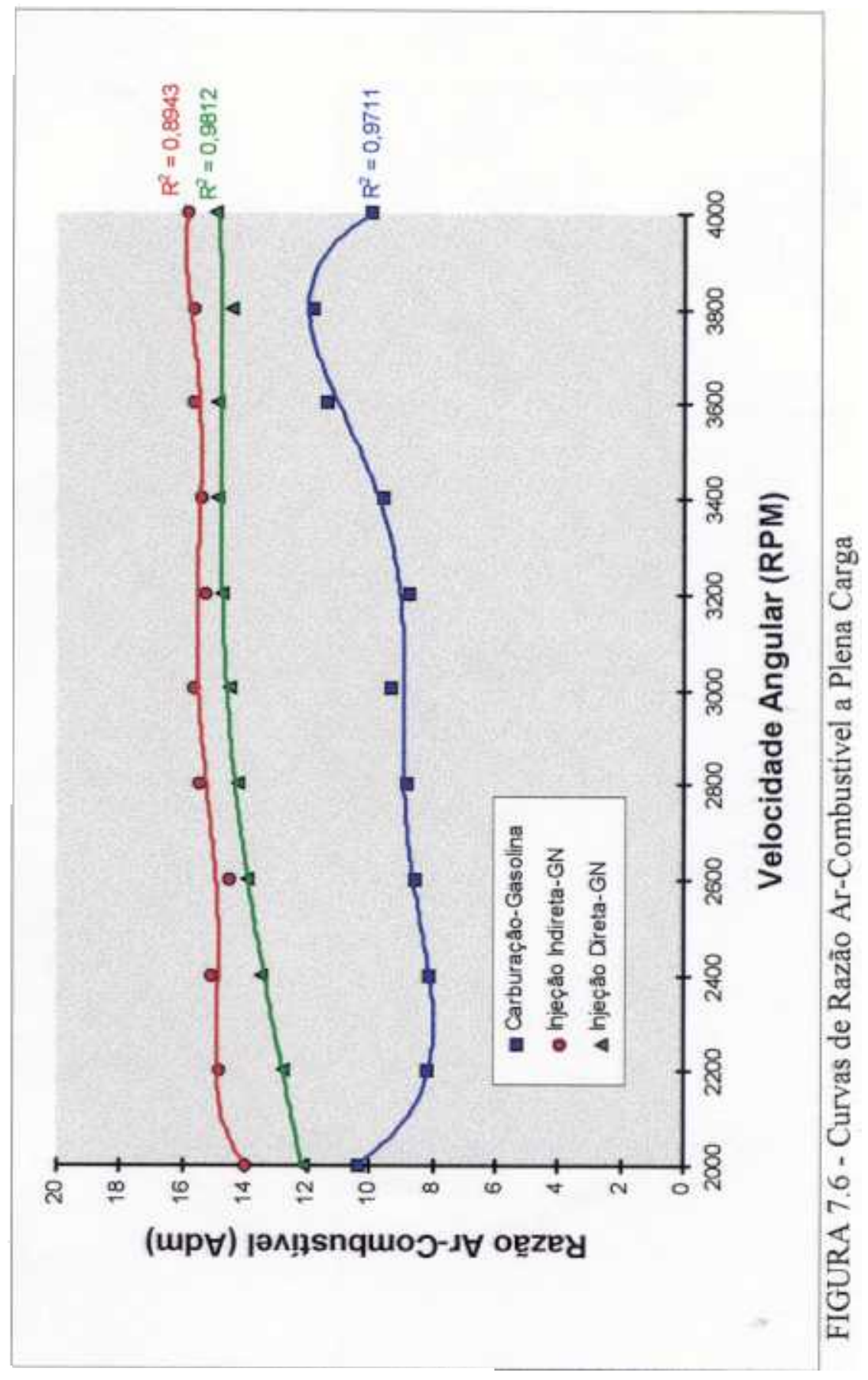




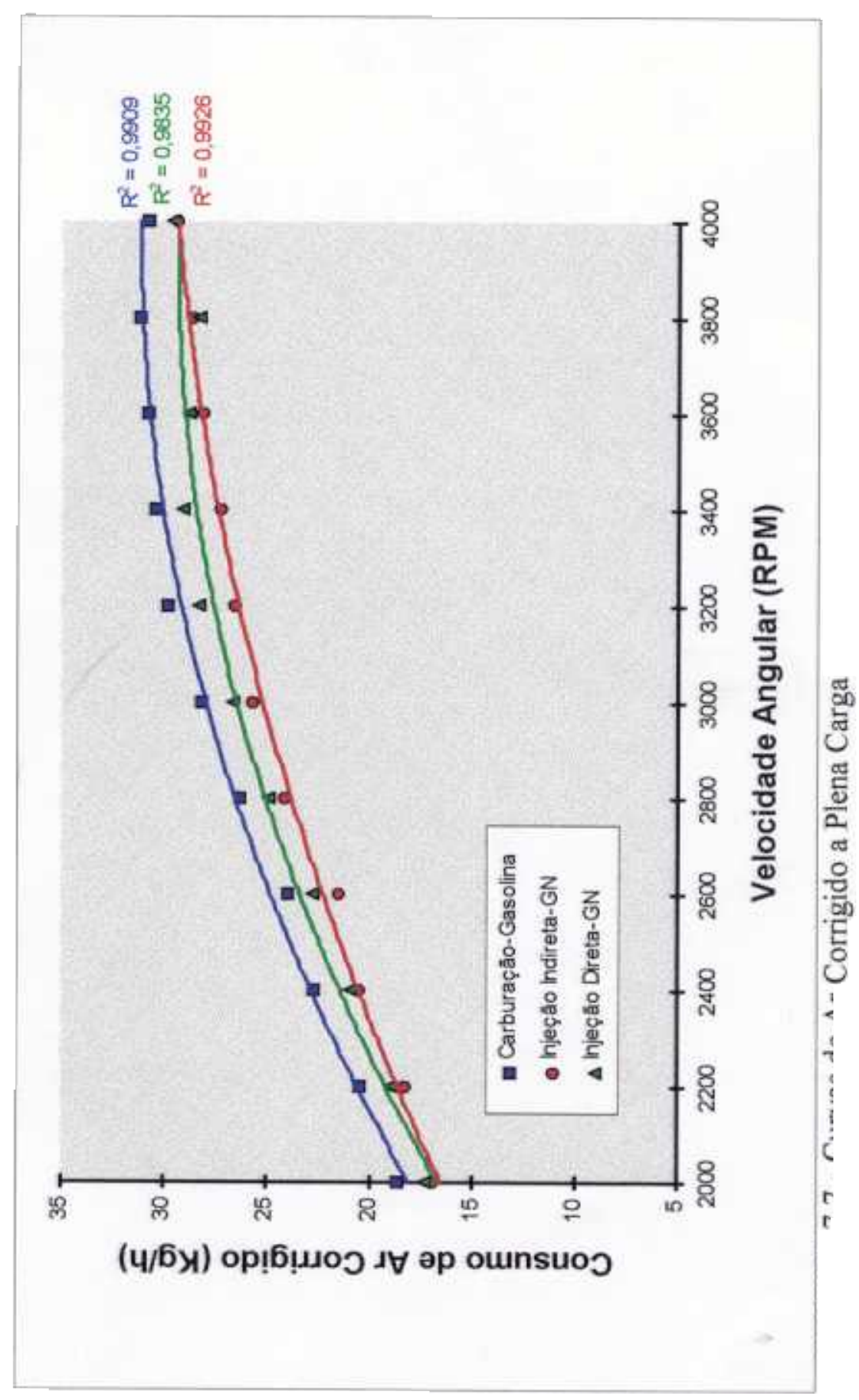




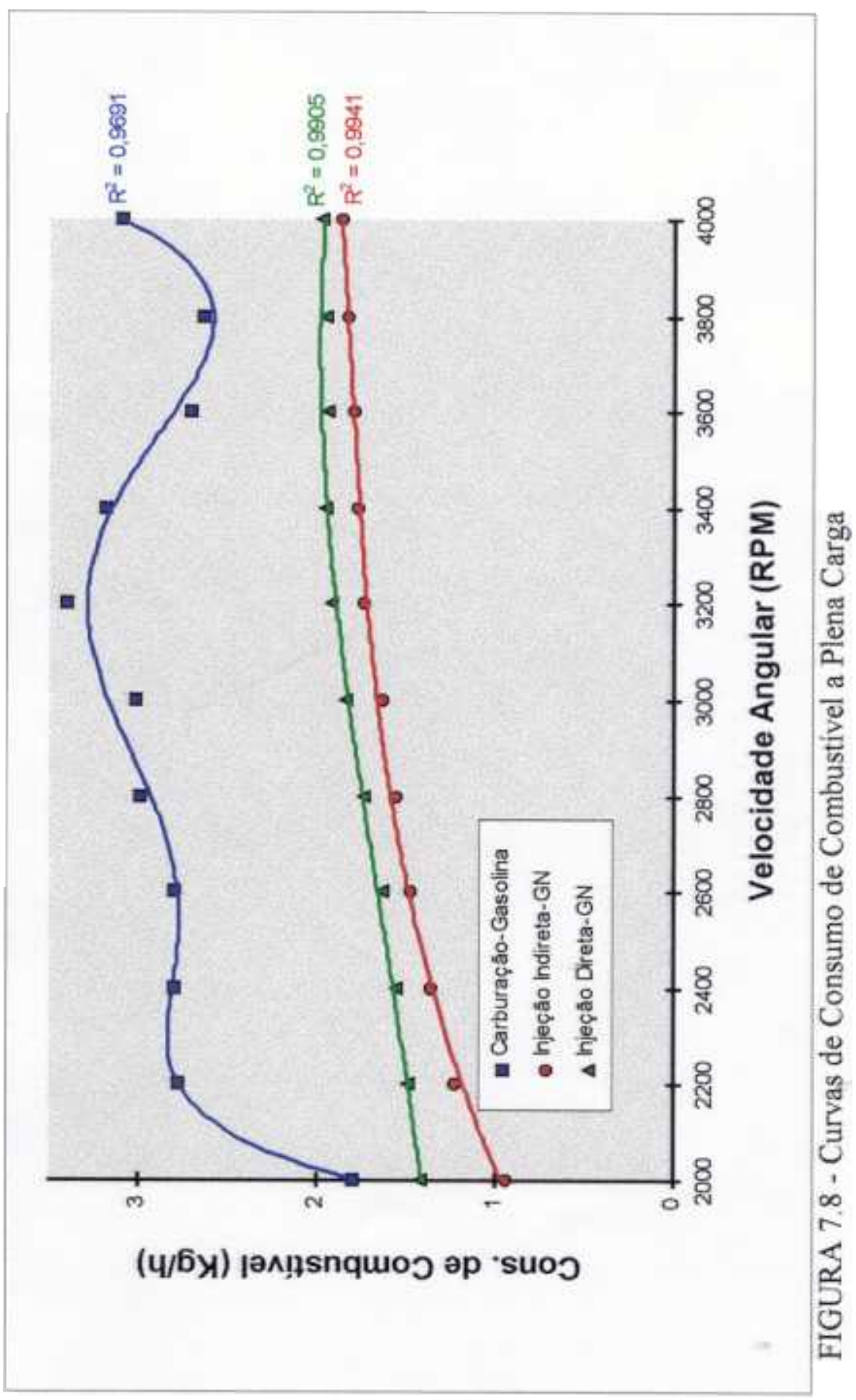




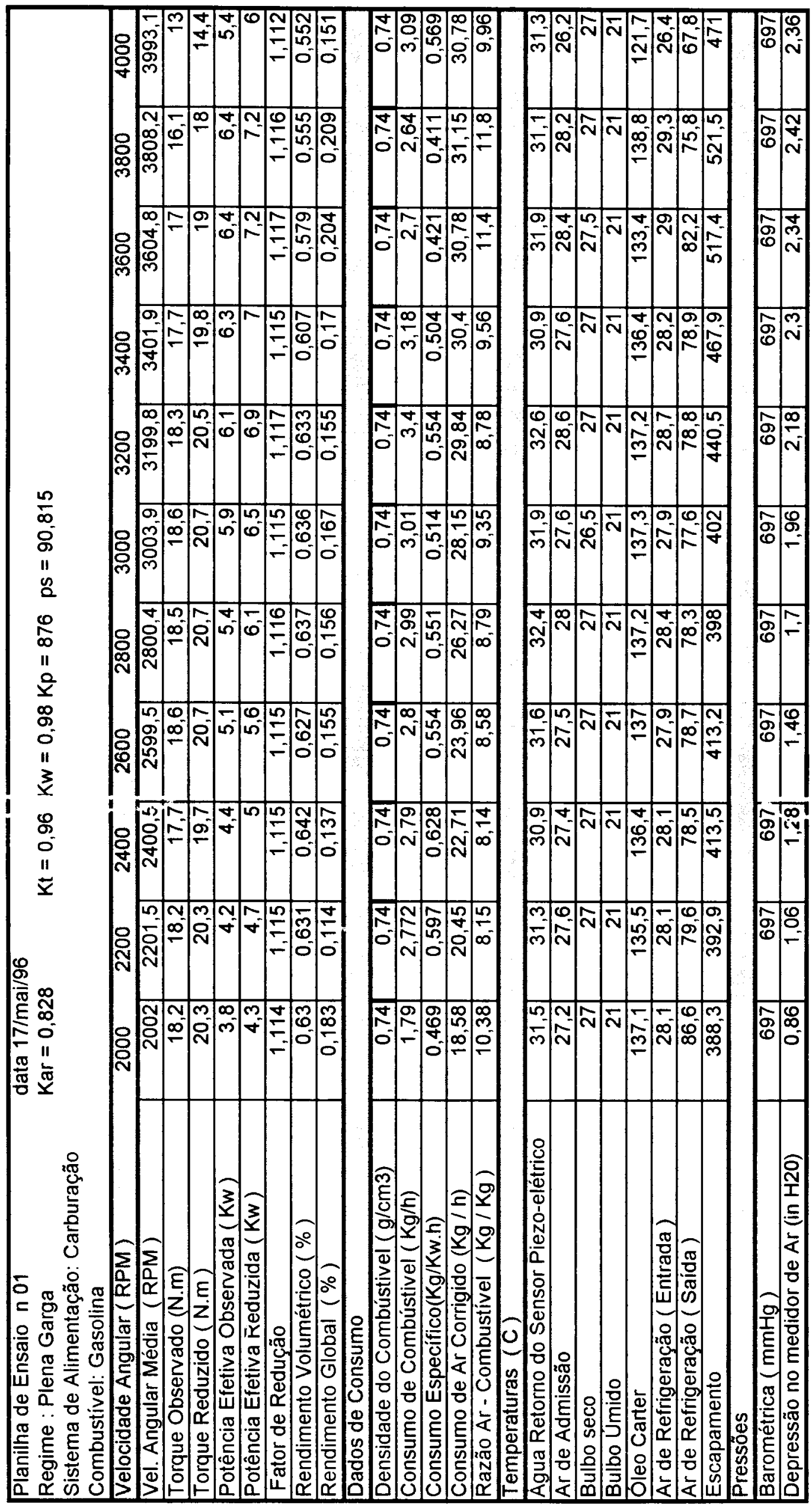




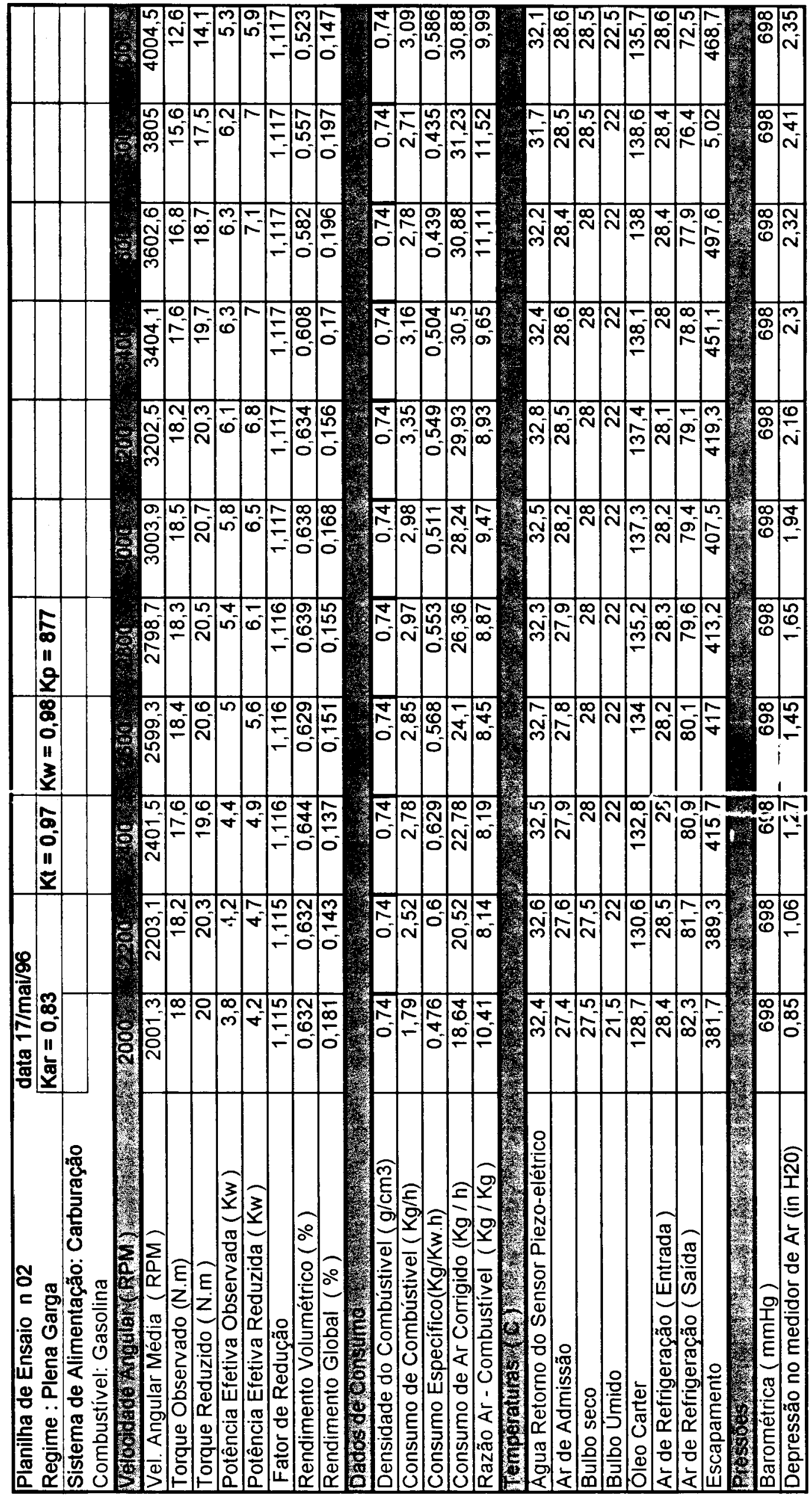




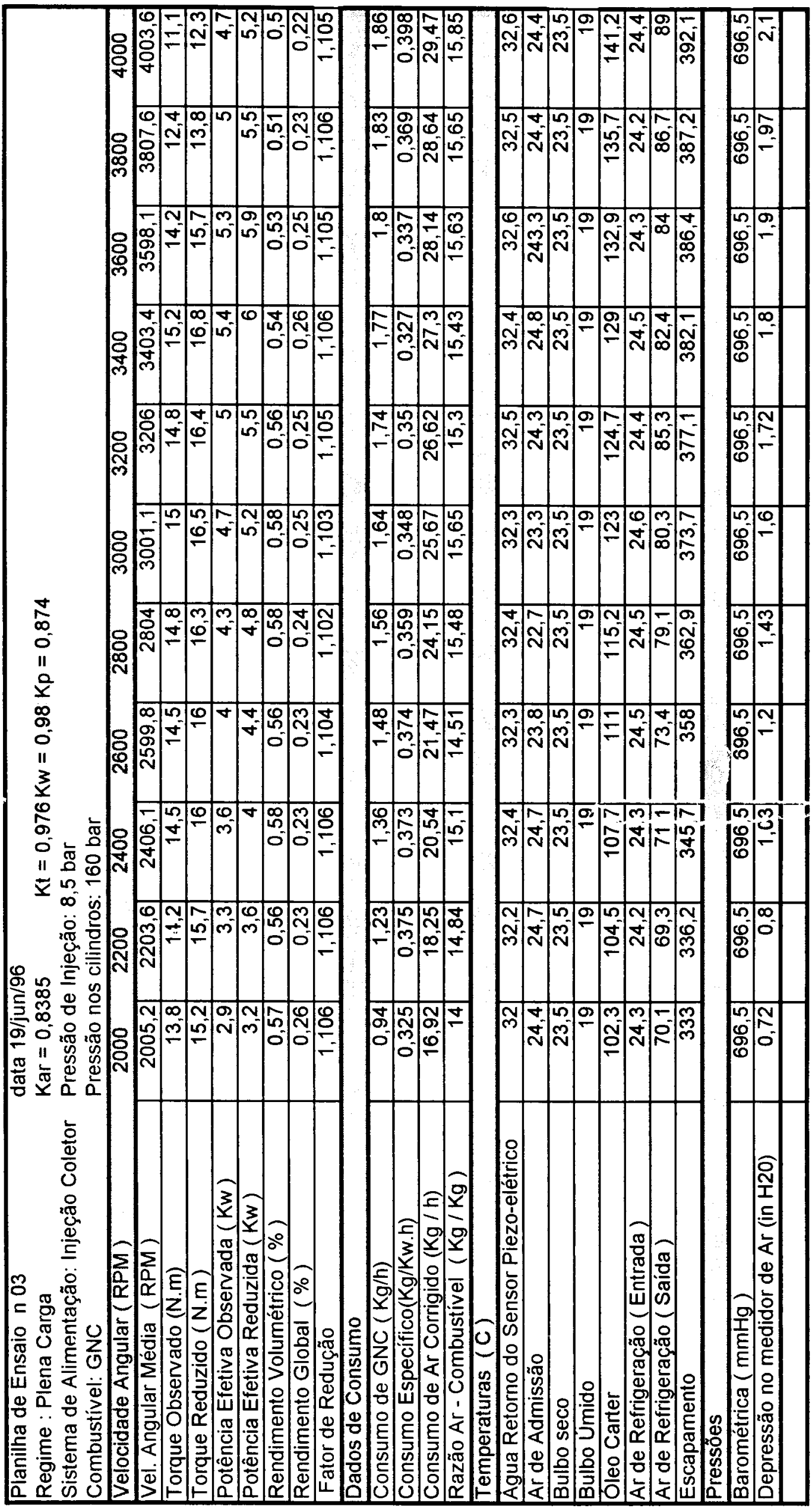





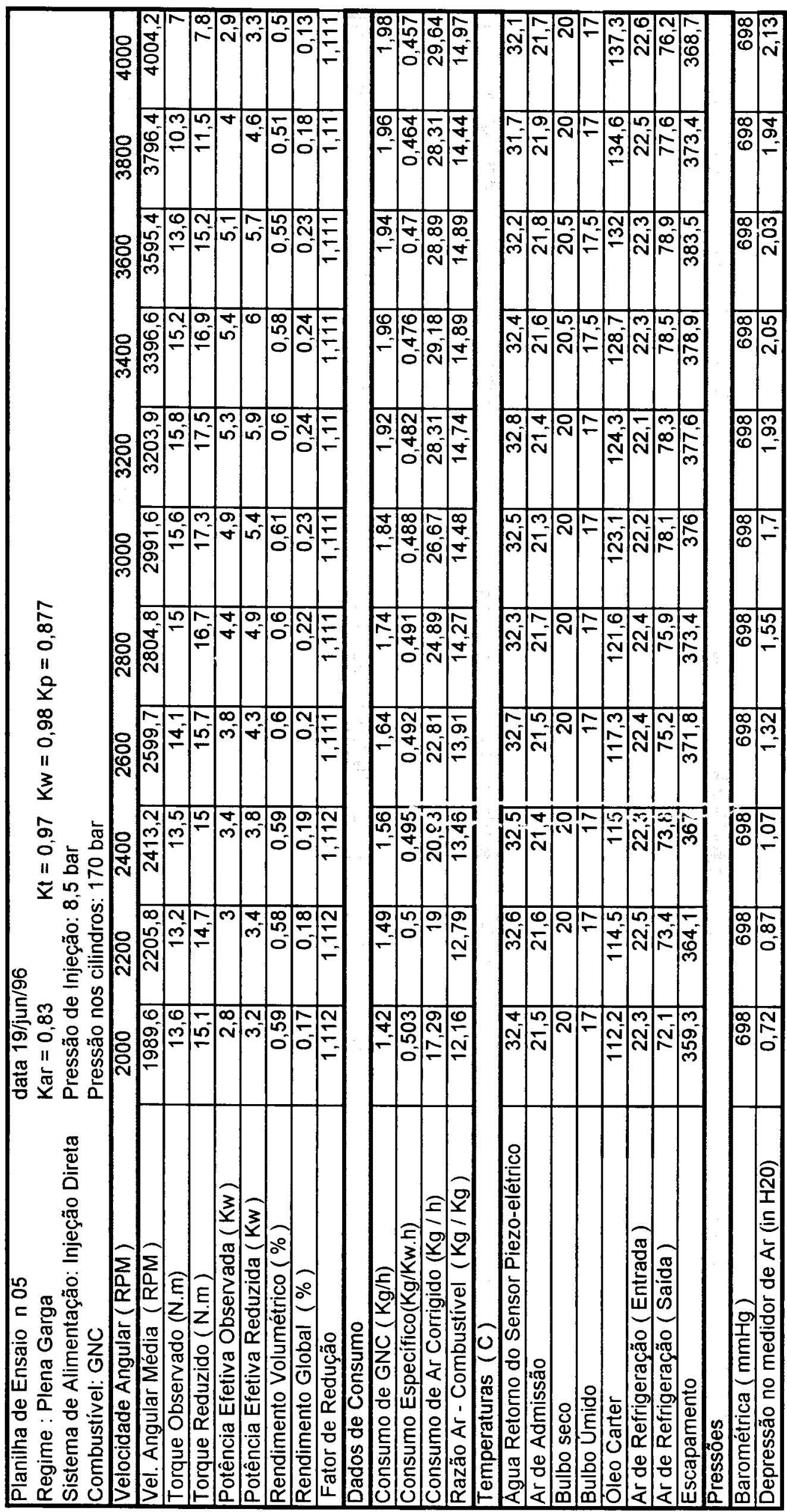




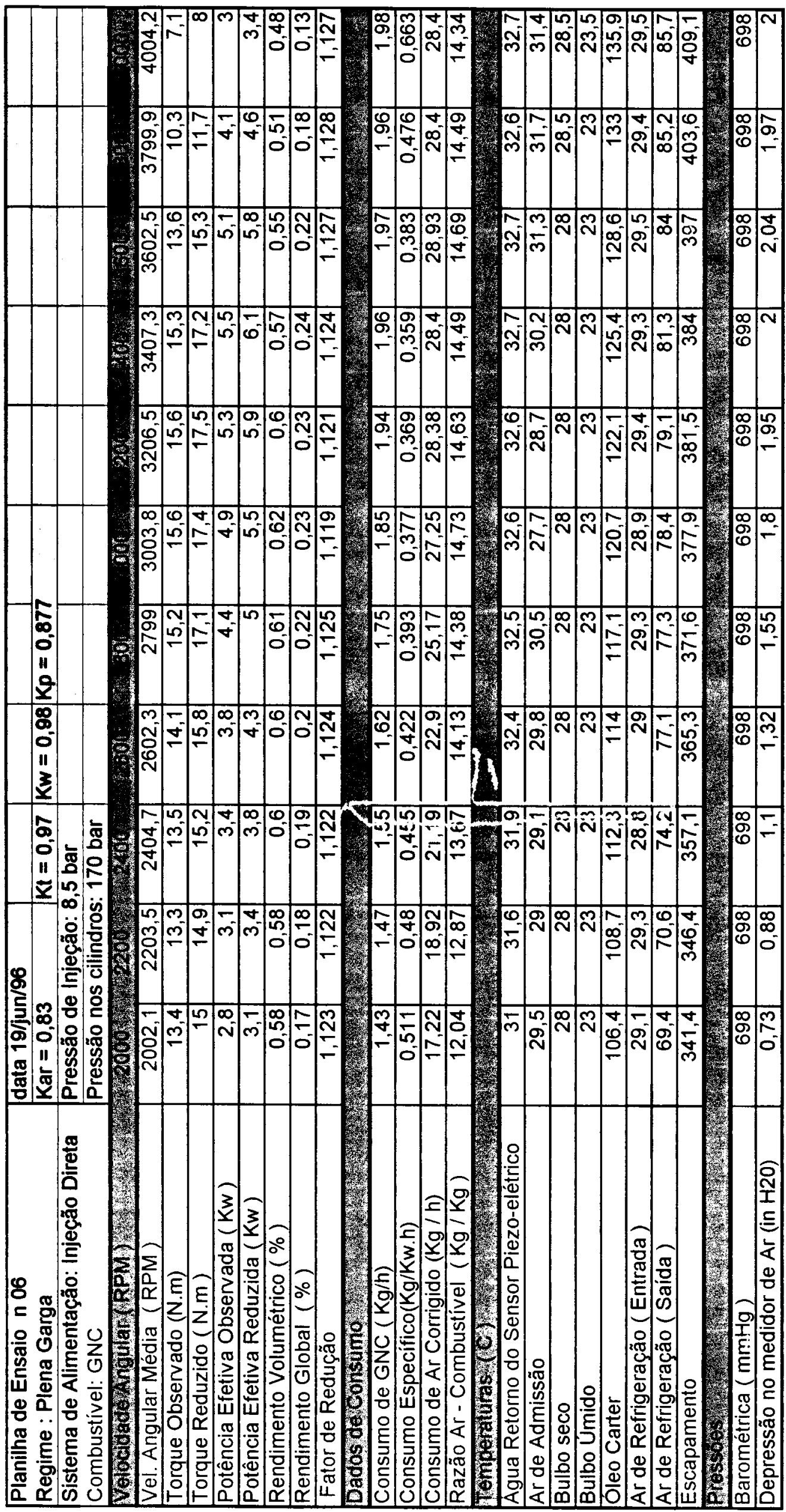




\section{CAPÍTULO 08 - CONCLUSÕES E SUGESTÕES}

\section{1 - CONCLUSÕES}

A partir dos fundamentos teóricos apresentados e resultados experimentais obtidos nesta pesquisa, pode-se estabelecer as seguintes conclusões:

i) 1) conjunto de injeção direta (CID), desenvolvido para injetar GN a baixas pressões no cilindro do motor, funcionou satisfatoriamente, permitindo uma operação regular (suave) do motor desde a condição de marcha lenta até o regime de plena carga do motor.

b) A principal limitação do CID consistia na baixa vazão de gás natural, a qual era uma característica da VEIC utilizada, sendo necessário um longo período de injeção para o estabelecimento do regime de plena carga do motor de testes.

c) O módulo de gerenciamento eletrônico, desenvolvido para gerenciar a injeção de GN, quer seja no cilindro ou no coletor de admissão do motor de testes, atendeu plenamente as expectativas de controle, uma vez que possibilitava o ajuste preciso da quantidade de $\mathrm{GN}$ requerido pelo motor, nos diferentes regimes de operação. 
d) Além da limitação da vazão da VEIC, a estratificação da carga no cilindro do motor, decorrente da geometria e da baixa turbulência da câmara de combustão do motor de testes, impossibilitaram que parte do periodo da injeção direta de GN fosse realizada no curso de compressão, como era pretendido inicialmente.

e) A injeção direta de GN, realizada durante o curso de admissão, resultou num ganho de rendimento volumétrico do motor da ordem de $3,74 \%$ com relação à injeção de GN no coletor de admissão. Em comparação com os ensaios de gasolina carburada, a injeção direta de GN apresenta uma queda de rendimento volumétrico da ordem de $6,5 \%$.

f) Apesar do ganho de rendimento volumétrico do motor operando com injeção direta de GNi em relação à injenão de GṆ nu coletor de admissão, a potência e o torque do motor, nas duas versões, permaneceram praticamente os mesmos até 3500 rpm. Porém, em rotações mais elevadas, devido ao menor tempo disponível para injeção no cilindro e às limitações de vazão da VEIC utilizada, a quantidade de GN introduzida no cilindro do motor de testes, não era o suficiente para queimar todo o oxigênio, resultando numa queda brusca de potência e torque do motor.

Enfim, os resultados obtidos nesta pesquisa, com o motor operando com injeção direta de GN a baixas pressões, mostram que existe uma perspectiva de aumento de potência do motor utilizando esta técnica de injeção. 


\section{2 - SUGESTÕES}

Para trabalhos futuros com injeção direta de GN a baixas pressões, recomenda-se observar os seguintes itens:

a) Utilizar válvulas injetoras combustivel (VEICs) que proporcionem maiores vazões de GN, reduzindo o periodo de injeção de combustível necessário para estabelecer o regime de piena carga do motor ou ainda, desenvolver VEICs específicas para este fim.

b) Utilizar sistemas de injeção direta de GN de baixas prissões em motores com câmara de combustão de alta performance.

c) Avaliar e comparar as emissões, principalmente de NOx, do motor funcionando com injeção direta de GN, proposto no presente trabalho, em relação a injeção convencional de GN no coletor de admissão. 


\section{REFERÊNCIAS BIBLIOGRÁFICAS}

ASSOCIAÇÃO BRASILEIRA DE NORMAS TÉCNICAS. (1982). NBR 5477 Apresentação de desempenho de motores - ACI (Alternativos de combustão interna / procedimento). Rio de Janeiro.

ASSOCIAÇÃO BRASILEIRA DE NORMAS TÉCNICAS. (1985). NBR 5484 Motores alternativos de combustão interna de ignição por compressão (diesel) ou de ignição por centelha (Otto) de velocidade angular variável - Método de ensaio. Rio de Janeiro.

ASSOCIAÇÃO RECIPROCA PETROLERA EMPRESARIAI LATINO AMERICANA. (1995). América latina y el mundo - Reservas Produccion. (Boletim Técnico), vol. 23, n2: p. 149-154, set.

AUTOMOTIVE eletricieletronic systems. (1989). 1.ed. BOSCH/SAE. 347p.

AUTOMOTIVE handbook. (1993). 3.ed. BOSCH. $852 \mathrm{p}$.

BARBOSA, C. R.F. (1990). Otimização da curva de avanço de centelha de um motor otto bi-combustivel alimentado com gás natural comprimido. Natal. 99p. Dissertação (mestrado) - Universidade Federal do Rio Grande do Norte.

BET, L. (1991). Avaliação do comportamento de um motor diesel, refrigerado a ar, funcionando como motor dual diesel-GNC. Natal. 204p. Dissertação (mestrado) - Universidade Federal do Rio Grande do Norte. 
BEVIER, W.E. et al. (1989). Adsorbent-enhanced methane storage for alternate fuel powered vehicles. Paper SAE 891638. 7p.

BOSCH. (1996). Sistema de injeção eletrônica de combustivel - LE-jetronic. (Apostila Técnica). $17 \mathrm{p}$.

BOWLER, L. L. (1980). Thorttle body fuel injection (TBI) - An integrated engine control system. Paper SAE 800164. 13p.

BRIGGS \& STRATION. (1989). Instrucciones de preparatión y servicio - Para motores de un cilindro 4 ciclos.

BRUNETTI, F. (1996). Combustiveis alternativos para motores de combustão interna. Revista Pesquisa \& Tecnologia da Faculdade de Engenharia Industrial, $n$ 16, p.14-24, jun.

CHAFFIN, C. et al. (1991). Conversion of gasoline engine to natural gas. SAE SP894. p.241-254.

CHENG, C. et al. (1991). Intake port phenomena in a spark-ignition at part load. Paper SAE 912401. 13p.

CHEVROLET. (1991). Sistema eletrônico de injeção de combustivel - EFI. 203p. (Manual de serviço).

CHEVROLET. (1993). Sistema múltiplo de injeção de combustivel. 19p. (Manual de treinamento).

CHIU, T.K. et al. (1991). Development of a viable dedicated natural gas vehicles. SAE SP-894. p.255-263.

CHOI, B. (1991). Reviews on present states of development and exhaust emission charactristics in natural gas fuled vehicles. Journal of Japan Automobile Research Institute. v.13, n.11, p.410-417. 
COSTA, F.G. (1988). Misturas ar-gás combustivel. In: $2^{\circ}$ CONGRESSO INTERNACIONAL SOBRE GÁS NATURAL, Salvador, 1988. Anais. Salvador. p.474-488.

DAISHO, Y. (1990). Performance and exhaust emissions of a two stroke sparkignition engine with a direct-injection system. JSAE Review, v.11, n.4, p.16-22, out.

DEGOBERT, P. (1995). Automobile and pollution. Institut Français du Pétrole/ SAE. R-150. 491p.

DIESEL Fuel Injection. (1994). BOSCH/SAE. 199p.

ESTON, N. E. (1992). Gás natural - Tecnologia. In: REUNIÃO TÉCNICA SOBRE GÁS NATURAL, São Paulo, 1992. Anais. São Paulo, AEA. p.107-117.

FERGUSON, C.R. (1986). Internal combustion engines - Apllied thermosciences. Singapore. Wiley \& Sons. 546p.

FIAT. (1993). Ignição e injeção eletrônica de combustivel -Tempra 16v. 30p (Manual de serviço).

FLEMING, R. D.; O'NEAL, G.B. (1985). Potential for improving the efficiency of $a$ spark ignition engine for natural gas fuel. Paper SAE 852073. 12p.

FONTES JÚNIOR, A.O. (1994). Avaliação do comportamento de um motor diesel de dois cilindros convertido para o ciclo otto, utilizando gás natural veicular. Natal. 184p. Dissertação (mestrado) - Universidade Federal do Rio Grande do Norte.

FRENCH, C.C.J. (1980). The engine challeng of the nineties. .In: SYMPOSIUM OF TECHNOLOGY METAL LEVE : THE MOTOR IN THE FUTURE, São Paulo, 1980. Proceedings, São Paulo. p.9-26.

FRYSZMAN, A. S. (1992). Gás natural - Viabilidade. In: REUNIÃO TÉCNICA SOBRE GÁS NATURAL, São Paulo, 1992. Anais. São Paulo, AEA. p.1-11. 
GLOECKLER, O. (1984). Gasoline injection: a report progress. Automotive Engineer, v. 9, n.1, p.42-46, fev./mar.

GLOECKLER, O. et al. (1980). Present status and future development of gasoline fuel injection systems for passenger cars. Paper SAE 80047. 15p.

GO-POWER SYSTEMS. Operation and installation of the M-500 air-fuel meter. Palo Alto, California. (Catálogo Técnico).

GOTO, Y.; NARUSAWA, K. (1996). Combustion stabilization of a spark ignition natural gas engine. JSAE Review, v.17, n.3, p.256-258, jul.

GOUVEIA, C.P. (1988). Posto de abastecimento de gás natural para uso automotivo. In: $2^{\circ}$ Congresso Internacional sobre Gás Natural, Salvador, 1988. Anais. Salvador, p.310-316.

HARA, K. et al. (1994). GNC utilization in small engine. Paper SAE 940763. 9 p.

HATANO, K. et al. (1994). Multi-mode variable timing engine. Automotive Engineering, v.102, n.2, p.111-114, fev.

HEYWOOD, J.B. (1988). Internal combustion engine fundamentals. New York. McGraw-Hill International. 930p.

ISHII, M. et al. (1994). Experimental studies on a natural gas vehicle. Paper SAE 942005. $11 \mathrm{p}$

JOSSON, R. (1992). Gás natural - viabilidade. In: REUNIĀO TÉCNICA SOBRE GÁS NATURAL, São Paulo, 1992. Anais. São Paulo, AEA. p.12-41.

KEATING, E.L. (1993). Apllied combustion. Nẹw York. Marcel Dekker. 569p.

KING, S. R. (1992). The impact of natural gas composition on fuel meetering and engine operational characteristics. Paper SAE 920593. 
KLIMSTRA, J. (1986). Interchangeability of gaseous fuels - The importance of the wobbe index. Paper SAE 861578. 12p.

KO, Y. et al. (1991). A study of direct fuel injection for natural gas engine. Journal of Japan Automobile Research Institute. v.3, n.6, p.200-203.

KOSER, L.F.M. (1988). Gás natural da extração ao consumo. In: $2^{\circ}$ CONGRESSO INTERNACIONAL SOBRE GÁS NATURAL, Salvador, 1988. Anais. Salvador. p. $153-164$.

KOWALEWICZ, A. (1984). Combustion systems - Of high-speed piston I.C. engines. Warszawa. Elsevier. 366p.

LASTRES, L.F.M. (1987). Utilização de gás natural em motores veiculares. Rio de Janeiro. Instituto Brasileiro do Petróleo- IBP. 17p.

LASTRES, L.F.M. (1986). Aspectos da utilização de gás natural em motores de combustão Interna. Rio di: Janeiro. CENPES-Petrobrás. (Comunicação DIPROD n.104/86; p.1-10.

LENZ, H.P. (1994). Emissions, air quality and effects of exhaust gas constituents. Warrendale. SAE SP-1046. $97 \mathrm{p}$.

LENZ, H.P. (1992). Misture formation in spark-ignition engines. New York. Springer-Verlag-Wien/SAE. 400p.

LISS, E. W.; THRASHER, W.H. (1991). Natural gas as a stationary engine and vehicular fuel. Paper SAE 912364. $12 \mathrm{p}$.

MACHADO, F. (1988). Anotações sobre utilizações do gás natural em motores do ciclo otto. Rio de Janeiro. Retécnica Autogás.

MAXWELL, T.T.; JONES, J.C. (1995). Alternative fuels - Emissions, economics, and performance. Warrendale. SAE R-143. 327p.

MIZUTANI, S. (1992). Car electronics. Nippondenso. 280 p. 
MUÑOZ, M.; PAYRI, F. (1989). Motores de combustion interna alternativos. Madrid. Fundaçion General-UPM. $725 \mathrm{p}$.

OBERT, E. F. (1971). Motores de combustão interna. Trad. por Luiz Carraro. Porto Alegre. Globo. 618p.

PASSARINI, L.C. (1993). Projeto e análise de válvulas eletromagnéticas injetoras de combustivel: Uma Nova Proposta. São Carlos. Tese (Doutorado) - Escola de Engenharia de São Carlos, Universidade de São Paulo.

PETROBRÁS-BR. (1988). Gás natural para fins industriais. Rio de Janeiro. 78p. (Apostila técnica).

PETROBRÁS-BR. (1989-a). Posto de compressão e abastecimento de gás natural. Boletim Informativo DISREC-BATAL. $7 p$.

PETROBRÁS-BR. (1989-b). Utilização de gás natural comprimido em motores do ciclo Otto. Rio de Janeirı). $28 \mathrm{p}$.

PETROBRÁS-BR. (1989-c). Utilização do gás natural em motores aspirados do ciclo diesel. Rio de janeiro. $31 \mathrm{p}$.

PETROBRAS-BR. (1996). Gás natural. Rio de Janeiro. 6 p. (Prospecto).

PINCIGHER, E.; LARANGEIRA, C. (1996). Injeção eletrônica de GNC - Todo gás. Revista Motor Show, v.14, n.156, p.62-65, mar.

PLINT, M:; MARTYR, A. (1995). Engine testing - Theory and pratice. Manchester. Elsevier. 295p.

PROBST, C.O. (1995). Bosch fuel injection \& engine management. Massachusetts. SAE. 216p.

RAYMOND, L. (1980). Next generation of engines., In: SYMPOSIUM OF TECHNOLOGY METAL LEVE : THE MOTOR IN THE FUTURE, São Paulo, 1980. Proceedings, São Paulo. p.27-45 
RIBBENS, W.B. (1993). Understanding automotive eletronics. $4^{\text {a }}$.ed. Indianapolis. SAMS. 392p.

RODAGÁS. (1989). Catálogo metano automotivo. São Paulo. Rodagás. 110p.

RODRIGUES, A.S. (1993). Sistemas de injeção central de combustivel em motores 1.8l. Paper SAE $931666.11 \mathrm{p}$.

SERVIÇO NACIONAL DE APRENDIZAGEM INDUSTRIAL. (1994-a). EB-560 /56Ib - Apostila do curso de autotrônica I - Injeção eletrônica de combustível single-point. São Paulo. 54p.

SERVIÇO NACIONAL DE APRENDIZAGEM INDUSTRIAL. (1994-b). EB-561 Apostila do curso de autotrônica I - Injeção eletrônica de combustivel multi-point. São Paulo. 150p.

SHIMOTANI, K. et al. (1996). Characteristics of gasoline in-cylinder direct injection engine. JSAE Review, v.17, n.3, p.267-272, Jul.

SILVA, E.P. et al. (1993). O estado da arte do uso de hidrogênio em veículos automotivos. In: $2^{\circ}$ CONGRESSO E EXPOSIÇÃO INTERNACIONAIS DE TECNOLOGIA DA MOBILIDADE, São Paulo, 1993. Paper SAE 931706. 10p.

SPRINGER, K. J. (1996). Personal transportation and sustainable development. In: $5^{\circ}$ CONGRESSO INTERNACIONAL DE TECNOLOGIA DA MOBILIDADE SAE BRASIL. São Paulo, 1996.9p.

SPRINGER, et al. (1994). Effect of GNC start - Gasoline run on emissions from a 3/4 ton pick-up truck. Paper SAE 941916. 15p.

STONE, R. (1993). Introduction to internal combustion engines. $2^{\mathrm{a}}$.ed. Warrendale. SAE R-129. 569p.

STURMAN, O.E. et al. (1995). A gnc specific fuel injector using latching solenoid technology. Paper SAE 951914. 8p. 
TAYLOR, C. F. (1985-b). The internal combustion engine in theory and practice. v.2, 2. M.I.T. Press

TAYLOR, C.F. (1985-a). The internal combustion engine in theory and practice. v.1, M.I.T. Press.

TENNANT, C.J. et al., "Turbocharging a Bi-fuel Engine for Performance Equivalent to Gasoline". Paper SAE n 942003, 10 p., 1994.

TOKIO GÁS, “Review Amual 1995". 58 p., 1995.

TOYOTA, “ Toyota Readies Direct-Injection Gasoline Engine for Prodution". Revista Automotive Engineering, vol. 104, n 11, 74-76 p., nov., 1996.

UNICH, A. et al., "Natural Gas: A Promising Fuel for I.C. Engines". Paper SAE 930929, 11p., 1993.

VIANA, J.N.S. ct al., "Turboalimentação de Motores a gás - Análise dos Efeitos" . VII SIMEA-AEA. 391-406 p.. 1993.

VOLKSWAGEN , "Sistema de Injeção MOTRONIC MPFI 9.0". (Apostila de Treinamento e Assistência Técnica), out., 1996.

VOLKSWAGEN, "Carro a Gás - Prefeitura de São Paulo Adota Combustivel Natural". Revista Rede em Notícias da VOLKSWAGEN do Brasil, ano XII, n 84, 7 p., jun./jul.,1996.

VOLKSWAGEN, "Controle de Emissões de Poluentes". (Apostila de Treinamento e Assistência Técnica". 34 p., nov., 1991.

VOLKSWAGEN, "Injeção de Combustível LE-Jetronic". (Apostila de Treinamento e Assistência Técnica". 52 p., nov., 1988.

VOLKSWAGEN, "Na Era do Gás". Revista Rede em Notícias da VOLKSWAGEN do Brasil, ano XI, n 82, 16-17 p., fev./mar.,1996. 
VOLKSWAGEN, "Novo Gol - Motor e Transmissão". (Apostila de Treinamento e Assistência Técnica". 24 p., Set., 1994.

VOLKSWAGEN, "Novo GOL $1000 \mathrm{MI}$ ". (Apostila de Treinamento e Assistência Técnica), 24 p., out, 1996.

VOLKSWAGEN, "Sistema de Injeção $A P W-8$ ". (Apostila de Treinamento e Assistência Técnica), out., 1996.

VOLKSWAGEN, "Sistema de Injeção Eletrônica CFI". (Apostila de Treinamento e Assistência Técnica”. 32 p., dez., 1992.

VOLKSWAGEN, "Sistema de Injeção Eletrônica EFI - Digital". (Apostila de Treinamento e Assistência Técnica". 8 p., agos., 1993.

WANG, W. et al., "A Study of Emissions From CNG and Diesel Fueled Heavy-Duty Vechicles". Paper SAE 932826, 10 p., 1993.

WEAVER, C. S., "Natural Gas Ve vicles - A Review of the State of the Art" Paper SAE 892133, p. 21, 1989.

WEAVER, C.S. \& TURNER, S.H., "Dual Fuel Natural Gas/Diesel Engines: Technology, Performance, and Emissions". Paper SAE 940548, 16 p., 1994. 


\section{LITERATURA CONSULTADA}

ABBUD, J.K. (1993). The maryland MTA LNG refueling system. Paper SAE 931819. 9p.

ADAMS, M. et al. (1991). The university of T'ennessee's natural gas vehicles challenge conversion 1991. SAE SP-894, p.231-239

ASHCRAFT, T. et al. (1991). The university of Oklahoma LNG conversion for the 1991 natural gas vehicle challenge. SAE SP-894, p.223-230

ÁVILA, M.T.; SANTOS, A.M. (1993). Uso do etanol pré-vaporizado em motores de ignição por centelha. In: CONGRESSO INTERNACIUNAL DA TECNOLOGIA DA MOBILIDADE - SAE BRASIL, 2, São Paulo, 1993. Paper SAE 93163. 4p.

BARBOSA, C.R.F. et al. (1990). Construção e Calibração de um sistema de medição do consumo de gas natural em banco de prova de motores. In: CONGRESSO DE INICIAÇÃO CIENTÍFICA DA UNIVERSIDADE FEDERAL DO RIO GRANDE DO NORTE, 2, Natal, 1990. Anais. Natal. p. 184

BARBOSA, C.R.F. et al. (1996). The performance of an Otto cycle bi-fuel engine with natural gas direct injection. In: CONGRESSO INTERNACIONAL DA TECNOLOGIA DA MOBILIDADE - SAE BRASIL, 5, São Paulo, 1996. Paper SAE 962381. 4 p. 
BARBOSA, C.R.F. et al. (1996). Desempenho de um motor estacionário a gasolina convertido para operar com injeção eletrônica de gás natural. In: CONGRESSO BRASILEIRO DE ENGENHARIA AGRICOLA, 25, CONGRESSO LATINOAMERICANO DE INGENIERIA AGRICOLA, 2, Bauru, 1996. Anais. Bauru, UNESP. p. 294 .

BARBOSA, C.R.F.; FONTES, F.A.O. (1992). Avaliação da queda de potência de um motor convencional alimentado com gás natural comprimido. In: CONGRESSO NORTE-NORDESTE DE ENGENHARIA MECÂNICA. João Pessoa,1992. Anais. Jõao Pessoa.

BARKHIMER, R.L.; WONG, H.C. (1995). Application of digital, pulse width modulated, sonic flow injectors for gaseous fuels. Paper SAE 951912. 6p.

BARRETO, M.R.S. (1998). Utilização de gás natural em motores aspirados do ciclo diesel. In: CONGRESSO INTERNACIONAL SOBRE GÁS NATURAL, Salvador, 1988. tnais. Salvador, p.278-309, jun.

BASS, E., (iSS3). Lúi conversion and HC' emissions speciation of a light-duty vehicle. Paper SAE 932745. 12 p.

BATES, G.J. et al. (1995). Ultra rapid natural gas port injection. Paper SAE 951913. 10p.

BEHNKEN, R. et al. (1991). Conversion of a light duty truck to dedicated compressed natural gas operation. SAE SP-894, p.273-281

BODNER, G.M.; PARDUE, H. L. (1995). Chemistry - An experimental science. 2.ed. New York. Wiley \& Sons. 983p.

BOEHM, R.F. (1987). Design analysis of thermal systems. New York. Wiley \& Sons. $266 p$.

BORCHARDT, I. G.; ÁLVARO, F.G. (1979). Termometria termoelétrica Termopares. Porto Alegre. Sagra. 79p. 
BRADEN, R. et al. (1991). 1991 NGV challenge entry. SAE SP-894, p.207-222

CASTRO, C.A. et al. (1994). Flexible ethanol Otto engine management system. Paper SAE 942400. 7p.

CELERE, S.W. (1980). Desempenho de motor de ignição por centelha com álcool etílico pré-evaporado. São Carlos, 143p. Tese (doutorado) - Escola de Engenharia de São Carlos, Universidade de São Paulo.

CHENG, F.P.J.; CHENG, E.P.C. (1991). Florida institute of technology 1991 NGV challenge: The design theory and conversion method. SAE SP-894, p.91-110

CHERRY, A. M. et al. (1992). Extending lean limit with mass-timed compression ignition using a catalytic plasma torch. Paper SAE 921556. $15 \mathrm{p}$.

COMPANHIA DE TECNOLOGIA DE SANEAMENTO AMBIENTAL.

Legislação federal, estadual e municipal - Programa de controle da poluição do ar por veículos automotivos. (Série docunentos).

CULP, A.W. (1991). Principles of energy conversion. Singapore. McGraw-Hill International. $551 \mathrm{p}$.

DE VITA V, R.; FIGUEIREDO M., P.J. (1994). The effects of venezuelan engines on two fuel injection technologies. Paper SAE 942411.

DOHERTY, K. et al. (1993). The initial development of a two-stroke cycle biogas engine. Paper SAE 932398. 8p.

EISELE, H. (1988). Microprocessador engine application. IN: SYMPOSIUM OF TECHNOLOGY METAL LEVE : THE MOTOR IN THE FUTURE, São Paulo, 1988. Proceedings. São Paulo. p.167-178

EMBORSKY, A. (1991). The NGV challenge: A controlled environment for natural gas. SAE SP-894, p. 283-290 
FÁBIO, M. S. (1995). Sistema de alimentação de motores com duplo combustivel metano e diesel. São Carlos, 121p. Tese (Doutorado) - Escola de Engenharia de São Carlos, Universidade de São Paulo.

FONTES, F.A.O. (1986). Influência do pré aquecimento do combustivel no desempenho de motor de ignição por centelha convencional para álcool etílico hidratado. Natal. Dissertação (mestrado) - Universidade Federal do Rio Grande do Norte.

FORMAN, A.W. (1985). Combustion theory - The fundamental theory of chemically reacting flow systems. Addison-Wesley. $680 \mathrm{p}$.

FRANKLIN, M.L. et al. (1994). A pc-based fuel and ignition control system used to map the 3-d surfaces of torque and emissions versus air-fuel ratio and ignition timing. Paper SAE 940546. 12p.

FRANKLIN, M.L. et al. (1994). Synchronous, simultaneous optimization of ignition timing and air-fuel ratio in a cas-fueled spark ignition engine. Paper SAE 940547. $10 \mathrm{p}$.

FULTON, J. et al. (1993). Hydrogen for reducing emissions from alternative fuel vehicles. Paper SAE 931813 . 9p.

GARRET, K. (1991). Prospects for gaseous alternative fuels improved for GPL and LNG. Automotive engeneer, v. 16, n. 1, p.38-41, fev./mar.

GARRET, T.K.; PRIAULX, H.N. (1996). Electronically controlled petrol injection. Automobile engineer, v.56, n.11, p.461-465, out.

GASTALDONI, I. (198?). Uso de biogás nos motores a pistão. $6 \mathrm{p}$.

GIORDANO, D.D.; PETERSEN, P.W. (1995). A turbocharged lean-burn 4.3 liter natural gas engine. Paper SAE 951939. 8p.

GRENN, C.J.; WALLACE, J.S. (1989). Eletrically atuated injetors for gaseous fuels. Paper SAE 892143. 12p. 
GSCHWEITL, K. el al. (1994). Real time knock analysis for automatic engine mapping and calibration. Paper SAE 942399. 13p.

HODGINS, K.B. et al., (1992). Intensifier-injector for natural gas fueling of diesel engines. Paper SAE $921553.11 \mathrm{p}$.

HOLMAN, J. P. (1996). Experimental methods for engines. Singapore. McGrawHill. 609 p.

HUTTON, J.L.; PEDERSON, P.C. (1992). A molbile C.NG refueling system for natural gas vehicles. Paper SAE 921580. 4p.

ISHI, M. et al. (1994). Research on the emission reduction potential of natural gas vehicles. JSAE Review, v.15, n.3, p.238-241, jul.

JÄÄSKELÄINEN, H. E.; WALLACE, J.S. (1995). Behaviour of a closed loop controlled air valve type mixer on a natural gas fuelled engine under trasient operation. Paper SAE $1: 1911$. 10p.

JONES, Y et al. (1991). The Ohio state university natural gas vehicle. SAE SP-894, p. $145-150$

KARIM, A.G. (1991). A examination of some measures for improving the performance of gas fuelled diesel engines at light load. Paper SAE 912366. 9p.

KARIM, G.A; WIERZBA, I. (1992). Methane-carbon dioxide mixtures as a fuel. Paper SAE $921557.11 \mathrm{p}$.

KATAOKA.K. et al. (1994). Combustion process of gaseous fuels in a closed vessel. JSAE review, v.15, n.3, p.235-261, jul.

KLIMSTRA, J.;WESTING, J.E. (1992). Performance of natural-gas-fueled engines with variable intake-manifold temperatures. Paper SAE 922364. 10p.

KO, Y. et al. (1992). Research and development of LNG vehicle for pratical use. Paper SAE 920594. 9p. 
KONO, S. (1995). Study of the stratified charge and stable combustion in DI gasoline engines. JSAE review, v.16, n.4, p.363-368, out.

KOYANAGI, K. et al. (1993). Effect of hydrogen jet on misture formation in a highpressure injection hydrogen fueled engine with sparck ignition. Paper SAE 931811. 10p.

KUBESH, J. et al. (1992). Effect of gas composition on octane number of natural gas fuels. Paper SAE 922359. 7p.

KUBESH, J. T. et al. (1995). Development of an eletronically-controlled natural gás-fueled john deere powertech 8.1L engine. Paper SAE 951940. 8p.

KUKONEN, C.A.; SHELEF, M. (1994). Hydrogen as an alternative automotive fuel: 1993 update. Paper SAE 940766. 21p.

LARSEN, R. et al. (1991). The 1991 natural gas vehicle challenge - developing dedicated naturil gas vehicle techonology. SAE SP-894, p.1-55

LATUSEK, J.P.; BURRAHM, R.W. (1993). Conversion of small utility engines to LPG fuel. Paper SAE 932447. 19p.

LENZ, H.P. et al. (1994). Emissions, air quality, and effects of exhaust gas constituents. SAE SP-1046. 109p.

LIN, Y.C.; HUFF, G.A. (1993). Absorbed natural gas (ANG): Fuel of the future. Paper SAE $931821.11 \mathrm{p}$.

LISS, W.E. et al. (1992). Fuel issues for liquefied natural gas vehicles. Paper SAE 922360. 16p.

LOPER, G.A.; DAVIS, D.M. (1991). Liquefied natural gas conversion of a GMC' truck. SAE SP-894, p.167-173

MALEEV, V.L. (1993). Internal combustion engines - Theory and design. Singapore. McGraw-Hill. 636p. 
MANTESE, A.A. (1992). Análise dos parâmetros diretores para a comutação de combustiveis alternativos em motores de ciclo otto. São Carlos, 66p. Dissertação (mestrado) - Escola de Engenharia de São Carlos, Universidade de São Paulo.

MATHIAS, E.; SHOSHIMA, Y. (1993). Autoadaptatividade na injeção eletrônica digital. Paper SAE 931680. 10p.

MATHIAS, E.; SHOSHIMA, Y. (1993). Injeção eletrônica digital single point G7.3 para motores a alcool. Paper SAE 931681. 10p.

MERCEDEZ-BENZ. (1989). Os veiculos comerciais e o meio ambiente. Diretoria de Desenvolvimento e Engenharia Experimental-GEM/EET. 25p., mai.

METAL LEVE. (1985). Motores de combustão interna. 114p. (Apostila de curso).

MIC/STI/INMETRO. (1986). Manual de conversão de veiculos para uso de gás natural comprimido. $20 \mathrm{p}$.

MORIMOTC, $K$. et al. (1992). Combustion characteristics in hidrogen fueled rotary engine. Paper SAE 920302 . 7p.

MOTOROLA. (1993) Engine control - Ignition/fuel injection management, petrol and diesel. Automotive Engineer, v. 18, n.1, p.38-41, Mar.

MURASE, E. et al. (1992). A comparative study of pulsed jet ignition. JSAE Review, v. 13, n.2, p.18-23, Abril.

NAGANUMA, T. et al. (1992). New gas mixer for gas engines - Optimized air-fuel ratio with negligible pressure loss. Paper SAE 922361. 12p.

NEC. (1993). Vehicle electronics - Sees active development of systems for tomorrow's vehicles. Automotive Engineer, v.18, n. 1, p.30-36, Mar.

NYE, J. ; KEEHAN,T.T. (1991). Conversion of a 1991 GMC pick up truck to natural gas operation. SAE SP-894, p.265-272 
NYLUND, N.; KYTO, M. (1993). Propane fueled heavy-duty vehicles. Paper SAE $9328179 \mathrm{p}$.

OHSUGA, M. et al. (1994). Air flow metering and combustion control for spark ignition engine. JSAE Review, v. 15, n. 1, p.73-75, jan.

OHYAMA, Y. et al. (1993). A control system using air flowmeter and electronically controlled throttle valve for spark ignition engines. JSAE Review, v.14, n.4, p.4-10, out.

OUELETTE, P.; HILL, P.G. (1993). Visualization of natural gas injection for a compression ignition engine. Paper SAE 921555. 23p.

PASSARINI, L.C.; PINOTTI, M. (1993). Metodologia para determinação de desempenho de válvulas eletro-magnéticas injetoras de combustivel para motores ICE. In: CONGRESSO INTERNALCIONAL DA MOBILIDADE - SAE BRASIL, 2, São Paulo, 1993. Paper SAE 931678. $12 \mathrm{p}$.

PENIDU H!LHO, P. (1983). Os motores de combustão interna. Belo Horizonte. Lemi. 699p.

PENIDO FILHO, P. (1981). Álcool combustivel - Obtenção e aplicações nos motores. São Paulo. Nobel. 256p.

PESCHKA, W.; ESCHER, W.J.D. (1993). Germany's contribution to the demonstrated techinical feasibility of the liquid-hydrogen fueled passenger automobile. Paper SAE 931812 . 18p.

PETRO-JECT TRAINING AND EQUIPMENT. (1988). Blocked fuel injectors can cause problems. Automotive Engineer, v.52, n. 1, p.18., jan./fev.

PETSINGER, R.E. (1994). Largest CNG fueling station in north america. Paper SAE 942408. 8p.

QUIGG, D. et al. (1993). Operational experience of compressed natural gas in heavy duty transit buses. Paper SAE 931786. 13p. 
ROHLING, R. et al. (1991). The university of British Columbia entry into natural gas vehicle challenge. SAE SP-894, p.175-183

SANTOS, A.M. (1986). Contribuições ao uso de combustiveis aditivados em motores de ignição por compressão. São Carlos, 106p. Tese (doutorado) - Escola de Engenharia de São Carlos, Universidade de São Paulo.

SATO, Y. et al. (1995). Combustion control of direct injection methanol engine using a combination of charge heating and exhaust gas recirculation. JSAE Review, v.16, n.4, p.369-373, out.

SCHUEHMACHER, B. et al. (1991). The development of GM's natural gas powered sierrra pick-up. SAE SP-894, p.85-89

SHIGLEY, J. E.;MISCHKE, C.R. (1989). Mechanical engineering design. Singapore. McGraw-Hill. 779p.

SHUDO, T. et al. (1995). The influence of the properties on combustion and emissinns in a DI stratified charge engine. JSAE Review, v.16, n.1, p.27-33. jan.

SIERENS, R. (1992). An experimental and theoretical study of liquid LPG injection. Paper SAE 922363. 13p.

SILVA, E. P. (1991). Introdução à tecnologia e economia do hidrogênio. Campinas. UNICAMP. $204 \mathrm{p}$.

SILVA, F.M. et al. (1996). Sistema de alimentação do motor a duplo combustivel Metano e diesel. In: CONGRESSO BRASILEIRO DE ENGENHARIA AGRÍCOLA, 25, CONGRESSO LATINO-AMERICANO DE INGENIERIA AGRÍCOLA, 2, Bauru, 1996. Anais. Bauru. 295p.

SMITH, D.H.; GETTEL, L.E. (1993). A compressed natural gas mass flow driven heady duty electronic engine management system. Paper SAE 931822 23p.

SUGA, T.; HAMAZAKI, Y. (1992). Development of Honda flexible fuel vehicle. Paper SAE 922276. 10p. 
SULATISKY, M.T. et al. (1995). Adaptting a geo metro to run on natural gas using fuel-injection technology. Paper SAE 951942. 14p.

TECALEMIT-JACKSON. (1964). Tecalemit-Jackson petrol injection. Automobile Engineer, v.54, n.8, p.307-313, jul.

TECNOMOTOR, "C.F.I - VW FORD - Sistema de Injeção Eletrônica de Combustivel". (Manual de Operações), 25 p., São Carlos-SP,1995.

TECNOMOTOR. (1995). EFI-MULTEC TBI 700 - Sistema eletrônico de injeção de combustivel. São Carlos. 52p. (Manual de operações)

TECNOMOTOR. (1995). SPI FIAT-Magnetti Marelli G6/G7 - Sistema eletrônico de injeção de combustivel. São Carlos. 36p. (Manual de operações)

TECNOMOTOR. (1995). TM 501 - Equipamento para teste e limpeza de válvulas injetoras. São Carlos. 12p. (Manual de Instruções)

TECNOMOTOR. (1995). LE-jetronic 2.1 - Sistema eletrônico de inieção de combustivel. São Carlos. 52 p. (Manual de operações)

TECNOMOTOR. (1996). UNO MILLE eletronic-microplex - Sistema de ignição eletrònica mapeada MAGNETI MARELLI. São Carlos. 10p. (Manual de operações)

TECNOMOTOR. (1995). EFI FORD $\quad I W$ - Sistema de injeção eletrônica de combustivel multipoint -EEC-IV. São Carlos. 24p. (Manual de operações)

TILLER, D. B. et al. (1993). Toughness testing of an all-composite fuel container for natural gas vehicles. Paper SAE 931785. 7p.

TORRES, F.J. (1986). Desempenho de motores de ciclo diesel convertidos para ciclo otto, visando a utilização de álcool etilico hidratado como combustivel alternativo. São Carlos, 105p. Tese (doutorado) - Escola de Engenharia de São Carlos, Universidade de São Paulo. 
TORRES, J.F.; VENANZI, D. (1984). Conversão de motores ciclo diesel para otto visando a utilização do metano como combustivel alternativo. In: CONGRESSO BRASILEIRO DE ENERGIA, 3, Rio de Janeiro, 1984. Anais: Rio de Janeiro. p.632-638, out.

TUMMALA, M. (1993). Simulation, testing and optimization of natural gas onboard storage system for automotive applications. Paper SAE 931820. 8p.

URUSHIHARA, T. (1996). Effects of swirl and tumble motion on fuel vapor behavior and mixture stratification in lean burn engine. JSAE Review, v.17, n.3, p.239-244, jul.

UYEHARA, O. A. (1995). Prechamber for lean burn for low Nox for natural gas. Paper SAE 951937. 39p.

VARDE, S. K.; BORH, T. (1993). MHC' and other conversions in a natural gas fueled engine. Paper SAE 931632. 10p.

VENANZI, D. (1972). Contribuição à técnica do emprego de alcool etilico em. motores de ciclo otto. São Carlos, 202p. Tese (doutorado) - Escola de Engenharia de São Carlos, Universidade de São Paulo.

VENANZI, D. et al. (1984). Efeito do combustível gasoso no desempenho do motor de ignição por centelha. In: CONGRESSO BRASILEIRO DE ENERGIA, 3, Rio de janeiro, 1984. Anais. Rio de Janeiro. p.852-588

VENANZI, D. et al. (1984). Desempenho de um motor de ignição por centelha, utilizando combustível gasoso. . In: CONGRESSO BRASILEIRO DE ENERGIA, 3, Rio de janeiro, 1984. Anais. Rio de Janeiro. p.616- 624

WALSER, M. et al. (1991). Texas tech university entry in the 1991 SAE natural gas vehicles challenge. SAE SP-894, p.159-166

WEBB, R.F.; DELMAS, P.J., (1991). New perspectives on auto propane as a massscale motor vehicle fuel. Paper SAE 911667. 13 p. 


\section{ANEXO A - FÓRMULAS UTILIZADAS PARA DETERMINAÇÃo DOS PARÂMETROS DE DESEMPENHO DO MOTOR DE TESTES APRESENTADOS NAS PLANILHAS 7.1 A 7.8.}

As fórmulas utilizadas para determinação dos parâmetros de desempenho do motor ensaiado, serão apresentadas na mesma ordem em que aparecem nas planilhas de ensaio.

\section{1 - TORQUE CORRIGIDO}

$$
T=4,45 \cdot L_{c c}+0,07
$$

$\mathrm{T}=$ torque corrigido $(\mathrm{N} \cdot \mathrm{m})$

$\mathrm{L}_{\mathrm{cc}}=$ leitura na célula de carga (N.m)

\section{2 - POTÊNCIA EFETIVA OBSERVADA}

$$
P=\frac{T \cdot N}{9549,3}
$$


$\mathbf{P}=$ potência efetiva observada $(\mathrm{kW})$

$\mathrm{N}=$ velocidade angular média do motor (rpm)

9549,3 = constante do dinamômetro

\section{3 - TORQUE REDUZIDO}

$$
\operatorname{Tr}=f_{a} \cdot T
$$

$\operatorname{Tr}=$ torque reduzido $(\mathrm{N} . \mathrm{m})$

$f_{a}=$ Fator de redução $(\mathrm{adm})$

\section{4 - POTÊNCIA REDUZIDA}

$$
\operatorname{Pr}=f_{a} \cdot P
$$

$\mathrm{Pr}=$ potência reduzida $(\mathrm{kW})$

$f_{\mathrm{a}}=$ Fator de redução $(\mathrm{adm})$

onde:

$$
\begin{gathered}
f_{a}=\frac{(99)^{1,2}}{p s} \cdot\left(\frac{273+t}{298}\right)^{0,6} \\
p s=p b-\frac{1}{75}\left\{e^{[21,106-(s 345,5 /(t u+273))]}-0,49(t s-t u) \frac{p b}{100}\right\}
\end{gathered}
$$


ps = pressão do ar seco $(\mathrm{kPa})$;

$\mathrm{pb}=$ pressão barométrica $(\mathrm{kPa})$;

ts = temperatura de bulbo $\operatorname{seco}\left({ }^{\circ} \mathrm{C}\right)$;

$\mathrm{tu}=$ temperatura de bulbo úmido $\left({ }^{\circ} \mathrm{C}\right)$.

\section{5 - RENDIMENTO VOLUMÉTRICO}

$$
\eta_{v}=\frac{2 \dot{m}_{a}}{\rho_{a, 0} \cdot V_{d} \cdot N}
$$

$\eta_{\mathrm{v}}=$ rendimento volumétrico $(\mathrm{adm})$

$\dot{m}_{a}=$ vazão mássica de ar corrigido aspirado pelo motor $(\mathrm{kg} / \mathrm{min})$;

$\rho_{\mathrm{a}, 0}=$ densidade do ar atmosférico $\left(\mathrm{kg} / \mathrm{m}^{3}\right)$;

$V_{d}=$ volume deslocado pelo pistão durante um curso $\left(\mathrm{m}^{3}\right)$;

$\mathrm{N}=$ velocidade angular média do motor $(\mathrm{rpm})$

\section{6 - RENDIMENTO GLOBAL}

$$
\eta_{v}=\frac{P}{m_{f} \cdot P C I_{f}}
$$


$\eta_{\mathrm{g}}=$ rendimento global (adm)

$\mathbf{P}=$ potência do motor $(\mathrm{kW})$

$\mathrm{PCI}_{\mathrm{f}}=$ poder calorífico superior do combustível $(\mathrm{KW} / \mathrm{Kg})$

\section{7 - CONSUMO DE COMBUSTÍVEL}

a) Consumo de Gás Natural

$$
\dot{m}_{g n c}=\frac{\sum_{k=1}^{n}\left(\frac{m_{f}-m_{i}}{t_{f}-t_{i}}\right)}{n}
$$

$\dot{m}_{g n c}=$ vazão mássica d.: GN consumida pelo motor $(\mathrm{kg} / \mathrm{s})$;

$\mathrm{m}_{\mathrm{i}}=$ massa de $\mathrm{GN}$ no instante inicial $\mathrm{t}=\mathrm{t}_{\mathrm{i}}(\mathrm{kg})$;

$m_{f}=$ massa de GN no instante final $t=t_{f}(k g)$;

$\mathrm{n}=$ número de medições efetuadas em cada ponto de ensaio.

\section{b) Consumo de Gasolina}

$$
\dot{m}_{g a s}=\frac{\sum_{k=I}^{n}\left(\frac{V_{f}-V_{i}}{t_{f}-t_{i}}\right) \cdot \rho_{g a s}}{n}
$$

$\dot{m}_{g a s}=$ vazão mássica de gasolina $(\mathrm{kg} / \mathrm{s})$;

$V_{i}=$ volume de combustível no instante $t=t_{i}\left(m^{3}\right)$; 
$V_{\text {if }}=$ volume de combustível no instante $t=t_{f}\left(m^{3}\right)$;

$\rho_{\text {gas }}=$ densidade da gasolina nas condições de ensaio .

$\mathrm{n}=$ número de medições efetuadas em cada ponto de ensaio.

\section{8 - CONSUMO ESPECÍFICO DE COMBUSTÍVEL}

$$
s f c=\frac{\dot{m}_{f}}{P}
$$

$\mathrm{sfc}=$ consumo especifico de combustivel, $(\mathrm{g} / \mathrm{kW} \cdot \mathrm{h}) ;$

$\dot{m}_{f}=$ vazão mássica de combust:vei sensumida, $(\mathfrak{g} / \mathrm{h}) ;$

$\mathbf{P}=$ potência observada, $(\mathrm{kW})$;

\section{9 - CONSUMO DE AR CORRIGIDO}

O vazão mássica de ar consumida pelo motor foi determinada utilizando-se um instrumento padrão que consiste de um tambor para equalização do fluxo de ar, contendo uma placa de orificio calibrado, termopar e manômetro diferencial de coluna dágua. A partir da medida de depressão, utiliza-se ábacos fornecidos pelo fabricante para determinação da vazão mássica de ar reduzido (corrigido para as condições 
padrão). Os fatores de correção de temperatura, pressão barométrica e umidade são apresentados nos ábacos fornecidos pelo fabricante ${ }^{1}$.

$$
\dot{m}_{a, r}=\dot{m}_{a} \cdot k_{t} \cdot k_{p} \cdot k_{w}
$$

$\dot{m}_{a, r}=$ vazão mássica de ar reduzida, $(\mathrm{kg} / \mathrm{h})$;

$\dot{m}_{a}=$ vazão mássica de ar aspirado pelo motor, $(\mathrm{kg} / \mathrm{h}) ;$

$\mathrm{k}_{\mathrm{t}}=$ coeficiente de correção para temperatura, $(\mathrm{adm})$;

$\mathrm{k}_{\mathrm{p}}=$ coeficiente de correção para pressão, (adm);

$\mathrm{k}_{\mathrm{w}}=$ coeficiente de correção para umidade, $(\mathrm{adm})$.

\section{0 - RAZÃO AR-COMBUSTÍVEL}

$$
A / F=\left(\dot{m}_{a, r} / \dot{m}_{f}\right)
$$

$\mathrm{A} / \mathrm{F}=$ razão ar-combustível, (adm)

$\dot{\boldsymbol{m}}_{a, r}=$ vazão mássica de ar reduzida, $(\mathrm{kg} / \mathrm{h})$;

$\dot{m}_{f}=$ vazão mássica de combustível consumida, $(\mathrm{g} / \mathrm{h}) ;$

\footnotetext{
${ }^{1}$ Manual de Instalação e Operação do Medidor de Ar M-500 da GO-POWER SYSTEMS
} 


\section{ANEXO B - EQUAÇÕES GERAIS APLICADAS EM SISTEMAS TERMODINÂMICOS ABERTOS.}

$\mathrm{Na}$ modelagem de um motor de combustão interna, é muito freqüente considerá-lo como um sistema termodinâmico aberto. Nestes modelos, as equações conservativas de energia e de massa são expressas comumente em função do tempo ou do ângulo trigonométrico no eixo de manivelas. A Figura B-1, apresenta um

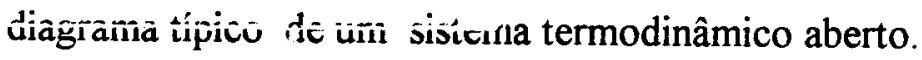

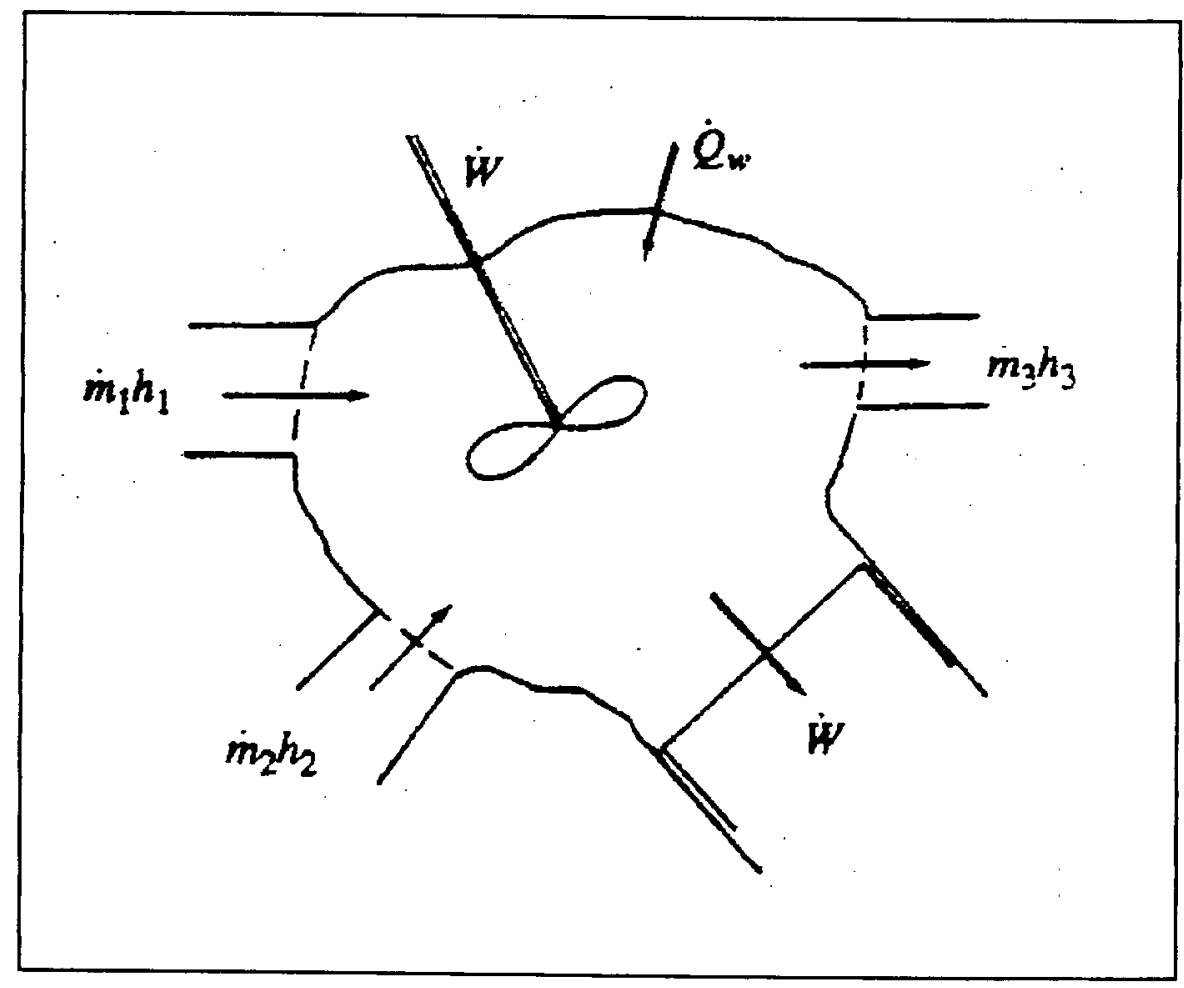

FIGURA B-1 - Sistema Termodinâmico Aberto. 


\section{1 - EQUAÇÕES DA CONSERVAÇÃO DE MASSA}

A taxa de variação de massa $(m)$ dentro do volume de controle (V.C.) de um sistema termodinâmico aberto é numericamente igual a soma líquida de fluxo de massa que entra e sai do volume de controle:

$$
\dot{m}_{i}=\sum_{j} \dot{m}_{j}
$$

por convenção o fluxo de massa que entra no V.C é positivo; e o fluxo de massa que sai do V.C é negativo. Nesta análise, é conveniente definir a fração de combustivel (f) como $\left(\mathrm{m}_{\mathrm{f}} / \mathrm{m}\right.$ ), onde $\left(\mathrm{m}_{\mathrm{f}}\right)$ representa a massa de combustível ( ou o combustível presente nos produtos da combustão ) em Lrr sistema aberto. assim:

$$
\dot{m}_{f}=\frac{d}{d t}\left(m_{f}\right)=\sum_{j} \dot{m}_{f, j}=\sum_{j} \dot{m}_{j} f_{j}
$$

derivando a eq. (4.10) resulta:

$$
f^{\prime}=\sum_{j}\left(\frac{\dot{m}_{j}}{m}\right)\left(f_{j}-f\right)
$$

a razão equivalente $(\phi)$ é definida como:

$$
\phi=\frac{f}{\left[(F / A)_{s}(I-f)\right]}
$$


Portanto, a taxa de variação da razão equivalente $(\phi)$ é:

$$
\dot{\phi}=\frac{I}{(F / A)_{s}} \cdot \frac{f^{\prime}}{(I-f)^{2}}
$$

\section{2 - CONSERVAÇÃO DA ENERGIA}

A primeira Lei da Termodinâmica aplicada ao volume de controle da Figura B-1, pode ser expressa matematicamente como:

$$
\dot{E}=\dot{Q}_{w}-\dot{W}+\sum_{j} \dot{m}_{j} h_{j}
$$

onde:

$\dot{E}=$ taxa de energia total do sistema;

$\dot{Q}_{w}=$ taxa total de transferência de calor ao sistema;

$\dot{W}=p \dot{V}=$ taxa de transferência de trabalho do sistema para o meio;

$\sum_{j} \dot{m}_{j} h_{j}=$ energia transferida pela massa (m) ao sistema

O termo $(\dot{E})$ da eq. (B-6) pode ser expresso como:

$$
\dot{E}=\frac{d}{d t}(m u)
$$


ou

$$
\dot{E}=\frac{d}{d t}(m h)-\frac{d}{d t}(p V)
$$

más:

$$
\begin{aligned}
& u=u(T, p, \phi) \\
& h=h(T, p, \phi) \\
& \rho=\rho(T, p, \phi)
\end{aligned}
$$

assim, a taxa de variação de $(u, h, \rho)$ podem ser escrito na forma:

$$
\dot{a}=\left(\frac{\partial \alpha}{\partial T}\right) \dot{T}+\left(\frac{\partial \alpha}{\partial p}\right) \dot{p}+\left(\frac{\partial \alpha}{\partial \phi}\right) \dot{\phi}
$$

onde $\alpha$ pode ser $\boldsymbol{u}, \boldsymbol{p}$ ou $\boldsymbol{h}$.

Da lei dos gases ideal tem-se:

$$
\begin{aligned}
& p=\rho \cdot R \cdot T \\
& p V=m . R . T
\end{aligned}
$$

aplicando as eqs. (B-13) e (B-14) na eq.(B-12) pra ( $\rho)$ e arrumando os termos encontra-se:

$$
\dot{p}=\frac{\rho}{\partial \rho / \partial p}\left(-\frac{\dot{V}}{V}-\frac{I}{\rho} \cdot \frac{\partial \rho}{\partial \phi} \dot{\phi}+\frac{\dot{m}}{m}\right)
$$


substituindo a eq. (B-15) na equações da energia (B-8) e expressando $\dot{E}$ da eq. (B-6) em termos de $\boldsymbol{u}, \boldsymbol{p}$ e $\boldsymbol{h}$ e suas respectivas derivadas parciais, obtem-se:

$$
\dot{T}=\left[B-\frac{p}{D} \frac{\partial u}{\partial p}\left(\frac{\dot{m}}{m}-\frac{\dot{V}}{V}+\frac{\partial R}{\partial \phi} \frac{\phi}{R}\right)-\frac{\partial u}{\partial \phi} \dot{\phi}\right] /\left(\frac{\partial u}{\partial T}+\frac{C}{D} \cdot \frac{p}{T} \cdot \frac{\partial \phi}{\partial \phi}\right)
$$

onde:

$$
\begin{aligned}
& B=-R \cdot T \frac{\dot{V}}{V}+\frac{I}{m}\left(\dot{Q}_{w}+\sum_{j} \dot{m}_{j} h_{j}-\dot{m} u\right) \\
& C=1+\frac{T}{R} \cdot \frac{\partial R}{\partial T} \\
& D=1-\frac{p}{R} \cdot \frac{\partial}{\partial p}
\end{aligned}
$$

ou ainda:

$$
\dot{T}=\frac{B^{\prime}}{A^{\prime}}\left[\frac{\dot{m}}{m}\left(1-\frac{h}{B^{\prime}}\right)-\frac{\dot{V}}{V}-\frac{C^{\prime}}{B^{\prime}} \dot{\phi}+\frac{l}{B^{\prime} m}\left(\sum_{j} \dot{m}_{j} h_{j}-\dot{Q}_{w}\right)\right]
$$

onde:

$$
\begin{aligned}
& A^{\prime}=\frac{\partial h}{\partial T}+\frac{\partial \rho / \partial T}{\partial \rho / \partial p}\left(\frac{1}{\rho}-\frac{\partial \boldsymbol{h}}{\partial p}\right) \\
& B^{\prime}=\frac{1-\rho(\partial h / \partial p)}{\partial \rho / \partial p}
\end{aligned}
$$




$$
C^{\prime}=\frac{\partial h}{\partial \phi}+\frac{\partial \rho / \partial \phi}{\partial \rho / \partial p}\left(\frac{1}{\rho}-\frac{\partial h}{\partial p}\right)
$$

As eqs.. (B-1), B-3), (B-4), (B-15) e (B-16) ou (B-20) são muito utilizadas em modelos de simulação de motores para determinação das propriedades do sistema em função do tempo. Em algumas aplicações específicas, estas equações podem ser substancialmente simplificadas.Para modelagem dos sistemas de admissão e exaustão, ou ainda seções destes sistemas, o parâmetro $\dot{V}$ é nulo (zero) e os efeitos de dissociação ( os termos $\partial u / \hat{p}, \hat{h} / \hat{\phi}$ e $\partial \mathrm{R} / \hat{\phi}$ ) são freqüentemente desprezados. Na modelagem do cilindro, durante o curso de compressão, estes efeitos de dissociação também são usualmente desprezados. REYWOOD (1988) 


\section{ANEXO C - ANÁLISE DAS INCERTEZAS}

\section{1 - ANÁLISE DAS INCERTEZAS}

Os principais parâmetros de desempenho de um motor de combustão interna, são comumente expressos em termos das variáveis independentes apresentadas na Tabela $\mathrm{C}-1$

\begin{tabular}{|l|l|c|}
\hline $\begin{array}{c}\text { VARIÁVEL } \\
\text { INDEPENDENTE }\end{array}$ & $\begin{array}{c}\text { EQUIPAMENTOS USADOS PARA } \\
\text { MEDIÇÃO }\end{array}$ & FAIXA DE INCERTEZA \\
\hline Velocidade Angular & Tacômetro analógico & $0,15 \%^{1}$ \\
\hline Torque & Célula de Carga & $0,0606^{2}$ \\
\hline Consumo de GN & Balança e cronômetro digital & $1^{3}$ \\
\hline Consumo de ar & $\begin{array}{l}\text { Placa de orifício calibrado, termopar e } \\
\text { manometro }\end{array}$ & $1 \%^{4}$ \\
\hline
\end{tabular}

\footnotetext{
${ }^{1}$ relativo ao fundo de escala do instrumento de medida. valor especificado pelo fabricante. ${ }^{2}$ corresponde ao desvio padrão da variável independente extraído da curva de calibração. ${ }^{3}$ idem.

${ }^{4}$ erro máximo estabelecido pela norma ABNT 8454, uma vez que o equipamento utilizado para medição da variável em questão é padrão.
} 
As faixas de incertezas dos valores medidos de cada variável independente, ilustradas Tabela C-1, foram obtidas por meio de curvas de calibração dos equipamentos de medição utilizados ou mediante especificação do fabricante dos instrumentos de medida.

A Tabela C-2, apresenta alguns parâmetros de desempenho do motor de interesse no experimento, os quais são calculados a partir das variáveis mostradas na Tabela C-1.

\begin{tabular}{|c|c|c|}
\hline $\begin{array}{c}\text { PARÂMETRO DE } \\
\text { DESEMPENHO }\end{array}$ & $\begin{array}{c}\text { VARIÁVEIS } \\
\text { INDEPENDENTES }\end{array}$ & INCERTEZAS \\
\hline Potência & Torque, víusidade angular & \\
\hline $\begin{array}{c}\text { Consumo específico de } \\
\text { combustivel }\end{array}$ & Jutência, Cons. Combustível & \\
\hline Rendimento volumétrico & $\begin{array}{c}\text { Consumo de ar, densidade, } \\
\text { velocidade angular }\end{array}$ & \\
\hline Rendimento global & Cons. de combustivel, potência & \\
\hline
\end{tabular}

Um método muito utilizado para análise das incertezas das variáveis dependentes tem sido proposto por Kline e McClintock.

Neste método, as incertezas das variáveis dependentes, são calculadas com base nas incertezas das variáveis independentes, medidas experimentalmente. HOLMAN (1994)

No método proposto por Kline e McClintock, a equação (c-1) é empregada para determinar as incertezas das variáveis dependentes. 


$$
w_{R}=\left[\left(\frac{\partial R}{\partial x_{1}} w_{1}\right)^{2}+\left(\frac{\partial R}{\partial x_{2}} w_{2}\right)^{2}+\cdots+\left(\frac{\partial R}{\partial x_{n}} w_{n}\right)^{2}\right]^{1 / 2}
$$

$w_{\mathrm{R}}=$ incerteza da variável dependente;

$\mathbf{R}=$ variável dependente;

$\mathbf{x}_{\mathbf{i}}=$ variável independente;

$\mathrm{w}_{\mathbf{k}}=$ incerteza da variável independente $(\mathrm{k})$;

n = número de variáveis independentes. 


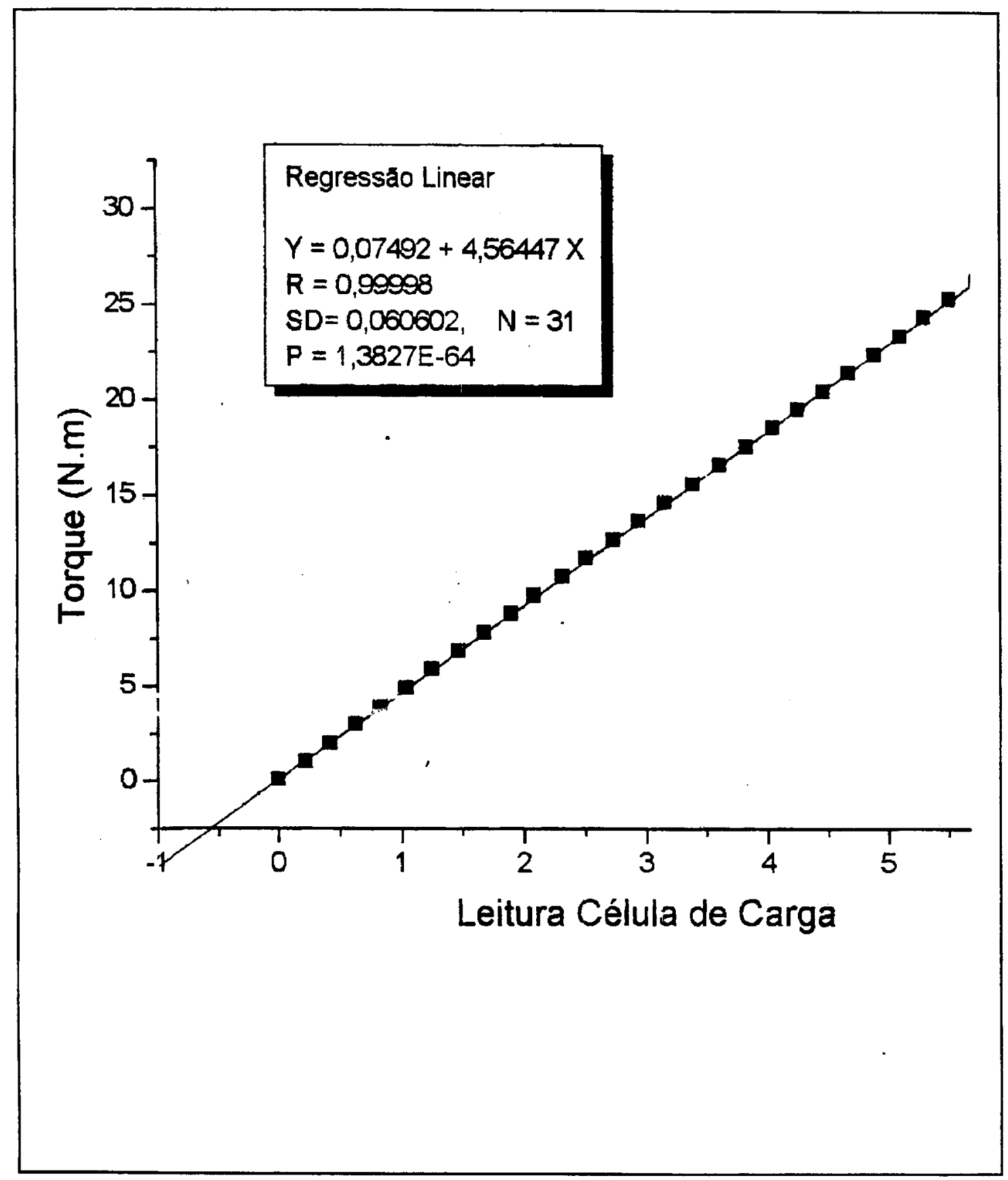

FIGURA C.1 - Curva de Calibração do Dinamômetro. 


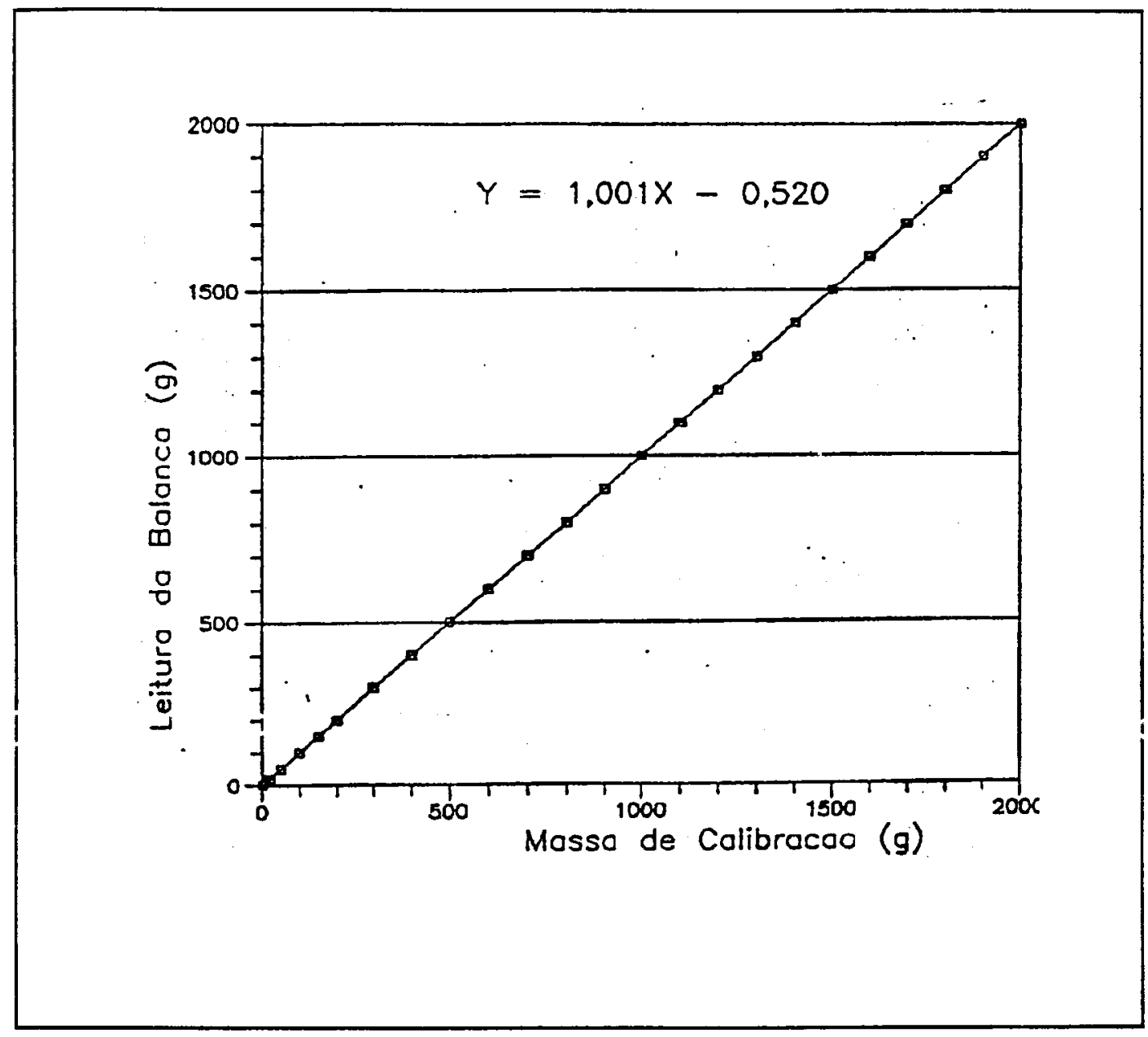

FIGURA C-2 - Curva de Calibração do Sistema de Medição do consumo de GN. 